Göttinger Beiträge zur Ethnologie Band 1

\title{
Burials, Texts and Rituals
}

Ethnoarchaeological Investigations in North Bali, Indonesia

edited by Brigitta Hauser-Schäublin and I Wayan Ardika

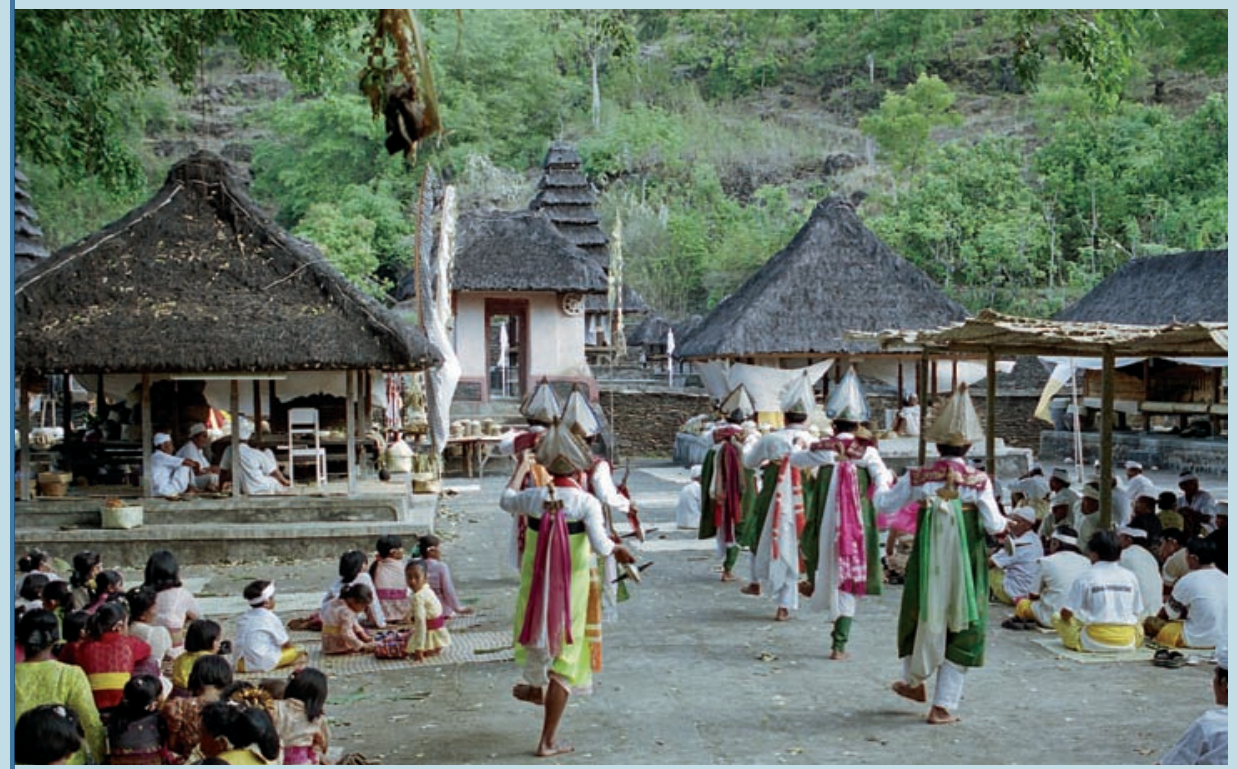



Burials, Texts and Rituals

edited by Brigitta Hauser-Schäublin and I Wayan Ardika

This work is licensed under the Creative Commons License 2.0 "by-nc-nd", allowing you to download, distribute and print the document in a few copies for private or educational use, given that the document stays unchanged and the creator is mentioned. Commercial use is not covered by the licence.

SORIERIGHIS RESERVED 
Published in 2008 by the Universitätsverlag Göttingen as Vol. 1 in the series „Göttinger Beiträge zur Ethnologie“

This series is a continuation of the „Göttinger Studien zur Ethnologie“ formerly published by LIT-Verlag 


\section{Burials, Texts and Rituals}

Ethnoarchaeological Investigations in North Bali, Indonesia

edited by Brigitta Hauser-Schäublin and I Wayan Ardika

Volume 1

Göttinger Beiträge zur Ethnologie

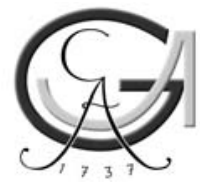

Universitätsverlag Göttingen 2008 


\section{Bibliographische Information der Deutschen Nationalbibliothek}

Die Deutsche Nationalbibliothek verzeichnet diese Publikation in der Deutschen Nationalbibliographie; detaillierte bibliographische Daten sind im Internet über $<$ http://dnb.ddb.de $>$ abrufbar.

\section{"Göttinger Beiträge zur Ethnologie” Series Editors}

Prof. Dr. Ulrich Braukämper and Prof. Dr. Brigitta Hauser-Schäublin

Institute for Cultural and Social Anthropology

Georg-August-University Göttingen

Theaterplatz 15, D-37073 Göttingen

\section{Editors of this Volume}

Brigitta Hauser-Schäublin

Institute for Cultural and

Social Anthropology

Georg-August-University Göttingen

Theaterplatz 15, D-37073 Göttingen
I Wayan Ardika

Fakultas Sastra Universitas

Udayana

Jalan Nias 13

Denpasar 80114, Bali, Indonesia

Gedruckt mit Unterstützung der Deutschen Forschungsgemeinschaft (DFG) und der Dr. Walther-Liebehenz-Stiftung, Göttingen

This work is protected by German Intellectual Property Right Law. It is also available as an Open Access version through the publisher's homepage and the Online Catalogue of the State and University Library of Goettingen (http://www.sub.unigoettingen.de). Users of the free online version are invited to read, download and distribute it. Users may also print a small number for educational or private use. However they may not sell print versions of the online book.

URL: http://webdoc.sub.gwdg.de/univerlag/2008/GBE1_bali.pdf

Translation: English Department, Udayana University Denpasar (Bali), Dr. John Coates, Göttingen

Layout: Anna-Teresa Grumblies, Frank-André Weigelt

Cover image: Baris-dance on the occasion of an annual festival held in the Village Temple of Julah (Bali). Photo: Brigitta Hauser-Schäublin 2001.

(C) 2008 Universitätsverlag Göttingen

http://univerlag.uni-goettingen.de

ISBN: 978-3-940344-12-0

ISSN: 1866-0711 


\section{Contents}

Brigitta Hauser-Schäublin and I Wayan Ardika:

Introduction ..

\section{Looking Back in Time}

Brigitta Hauser-Schäublin:

\section{Sembiran und Julah - Sketches of History}

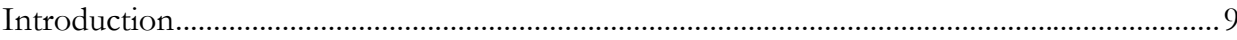

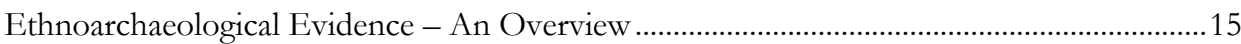

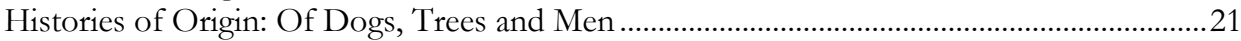

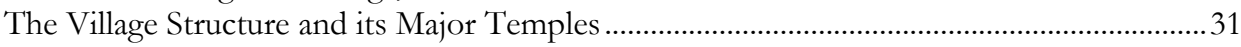

Between Stratification and Equality, Regional Integration and Autonomy .............................60

Marie-Louise Nabholz-Kartaschoff:

\section{The Textiles of Sembiran}

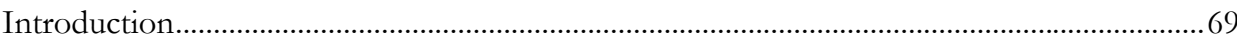

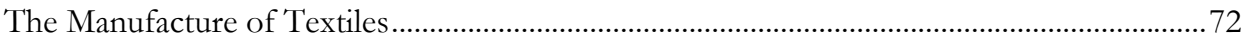

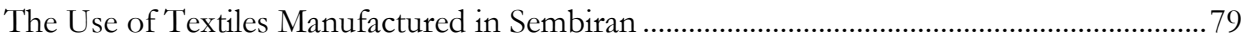

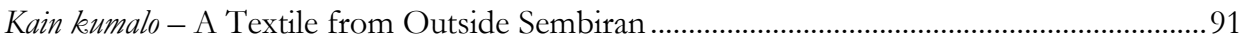

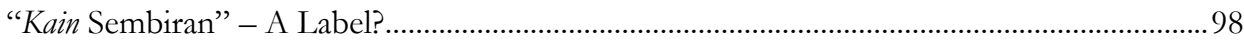

Parba Cili-A Lamak-Style Hanging ......................................................................................... 108

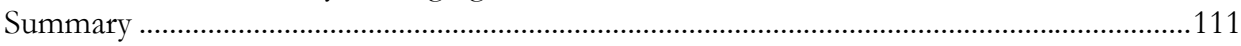


I Wayan Patera:

\section{Sanggah Dawa in the Life of Pacung Community}

Introduction 119

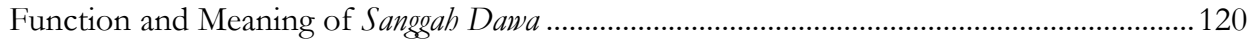

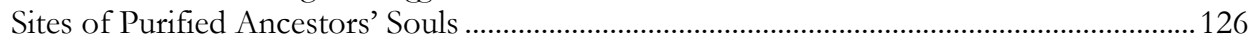

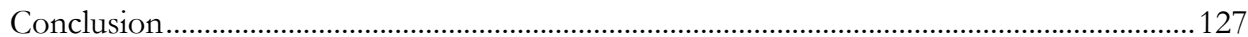

\section{Environment and Change}

Enrico Kalb:

Changes in the Landscape

Introduction

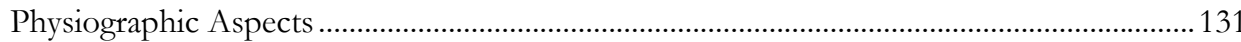

Geology

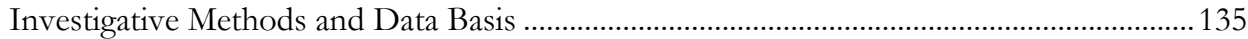

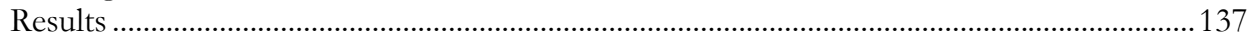

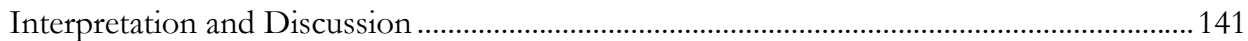

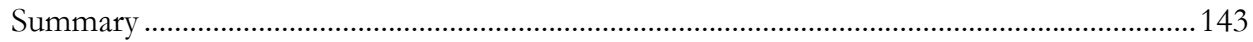

\section{Archaeological Evidence and its Interpretation}

I Wayan Ardika:

Archaeological Traces of the Early Harbour Town

Introduction

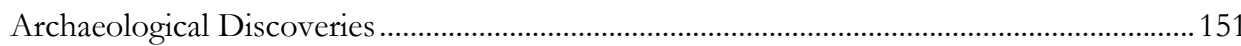

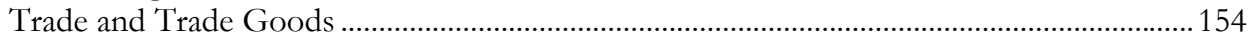

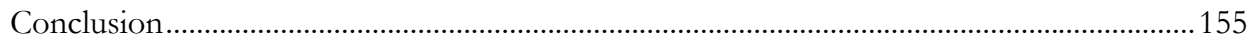

I Made Suastika:

Traces of Human Life Style from the Palaeolithic Era to the Beginning of the First Century AD

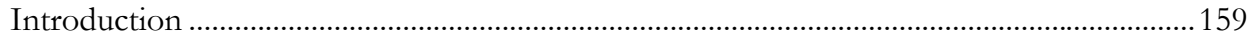

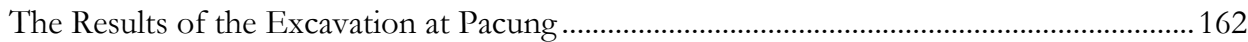

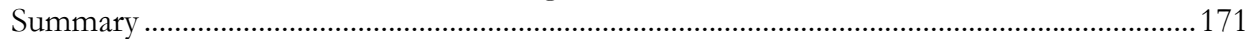

Marini Drawatik:

The Burial System at Pacung

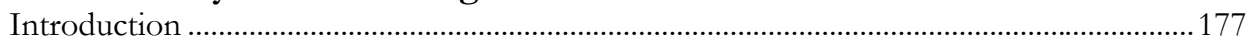

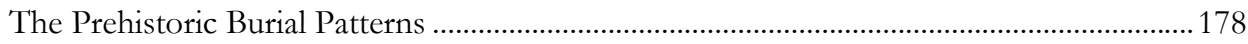

The Relation between the Current and the Prehistoric Burial System .................................. 184

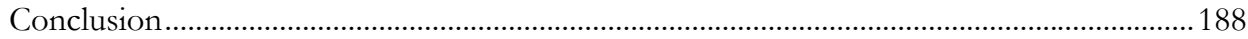


Michael Schultz:

Short Report on the Microscopic Examination of Bone Samples from a Neolithic Burial

Introduction

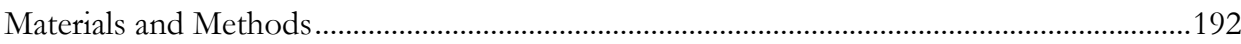

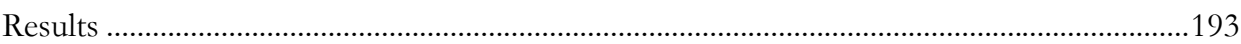

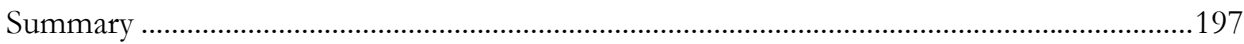

I Ketut Setiawan and Rochtri Agung Bawono:

\section{Excavation in Julah's Temporary Settlement of Upit}

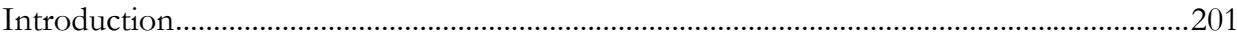

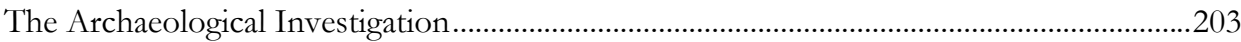

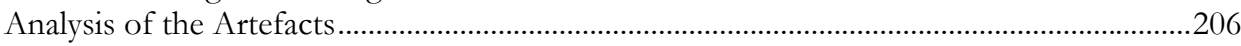

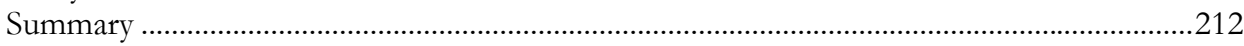

I Ketut Setiawan:

\section{Socio-Political Aspects of Ancient Julah}

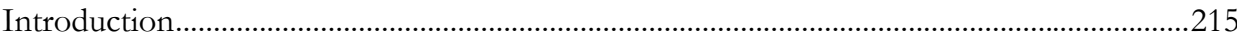

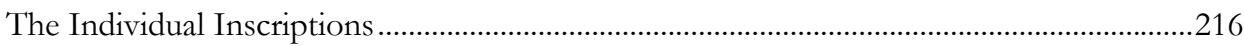

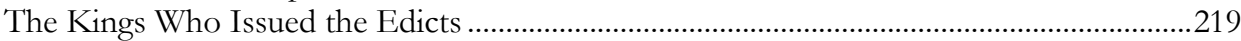

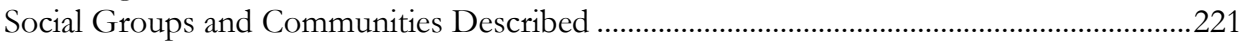

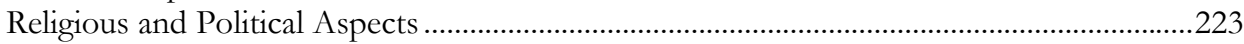

\section{Appendix}

\section{Sembiran Inscriptions}

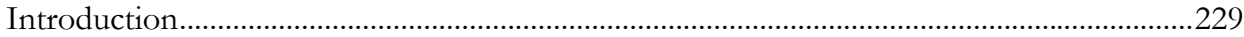

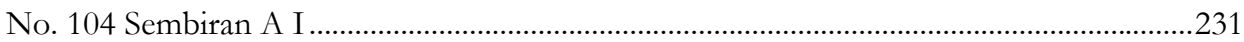

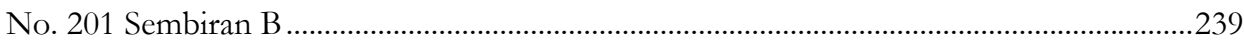

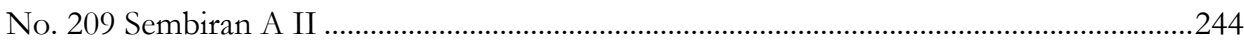

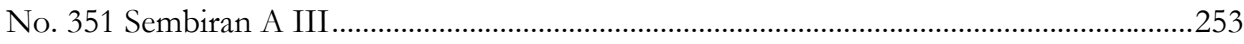

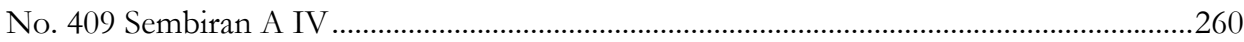

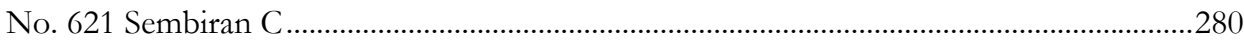

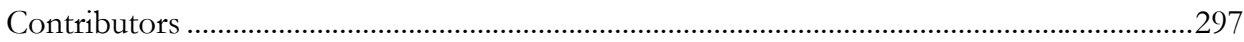





\section{Introduction}

Brigitta Hauser-Schäublin and I Wayan Ardika

This book is the outcome of the cooperation between Fakultas Sastra Universitas Udayana Denpasar (Bali), Indonesia, and the Institute of Cultural and Social Anthropology, University of Göttingen, Germany. Based on the results of the longstanding research in North Bali of the archaeologist I Wayan Ardika, Fakultas Sastra, Universitas Udayana and of the Balai Arkeologi Denpasar, the Pusat Arkeologi Nasional in Jakarta, the anthropologist Brigitta Hauser-Schäublin, Göttingen University, suggested an ethnoarchaeological project (under the auspices of Lembaga Ilmu Pengetahuan, Jakarta) in which Ardika acted as the academic counterpart.

The ethnoarchaeological project can be seen as an attempt to bring together various pieces of cultural evidence: among these are the findings produced by the archaeological excavations documenting a time as far back as the first century BC. Further evidence consists of the royal edicts, the so-called Sembiran Inscriptions (Goris 1954), written on copperplates; they were issued by kings between the $10^{\text {th }}$ and $12^{\text {th }}$ century. These inscriptions are testimonies of one of the earliest known kingdoms in Bali; they display significant Indian influence (see Appendix).

The preconditions for ethnohistorical research therefore seemed favourable since all these data originated from the same area in North Bali, namely the area of the villages of Julah, Pacung and Sembiran (Kecamatan Tejakula, Kabupaten Buleleng). Moreover, the village name of Julah appeared already in the copperplate inscriptions; it was to this village and their inhabitants that these royal edicts were 
addressed. And it is in today's Julah - as well as in Julah's sibling village of Sembiran - that these royal edicts are still kept and venerated as sacred heirlooms. Nevertheless, it needs to be pointed out that the continuity in name does not preclude continuity in population or culture, as will become clear in some of the contributions to this book.

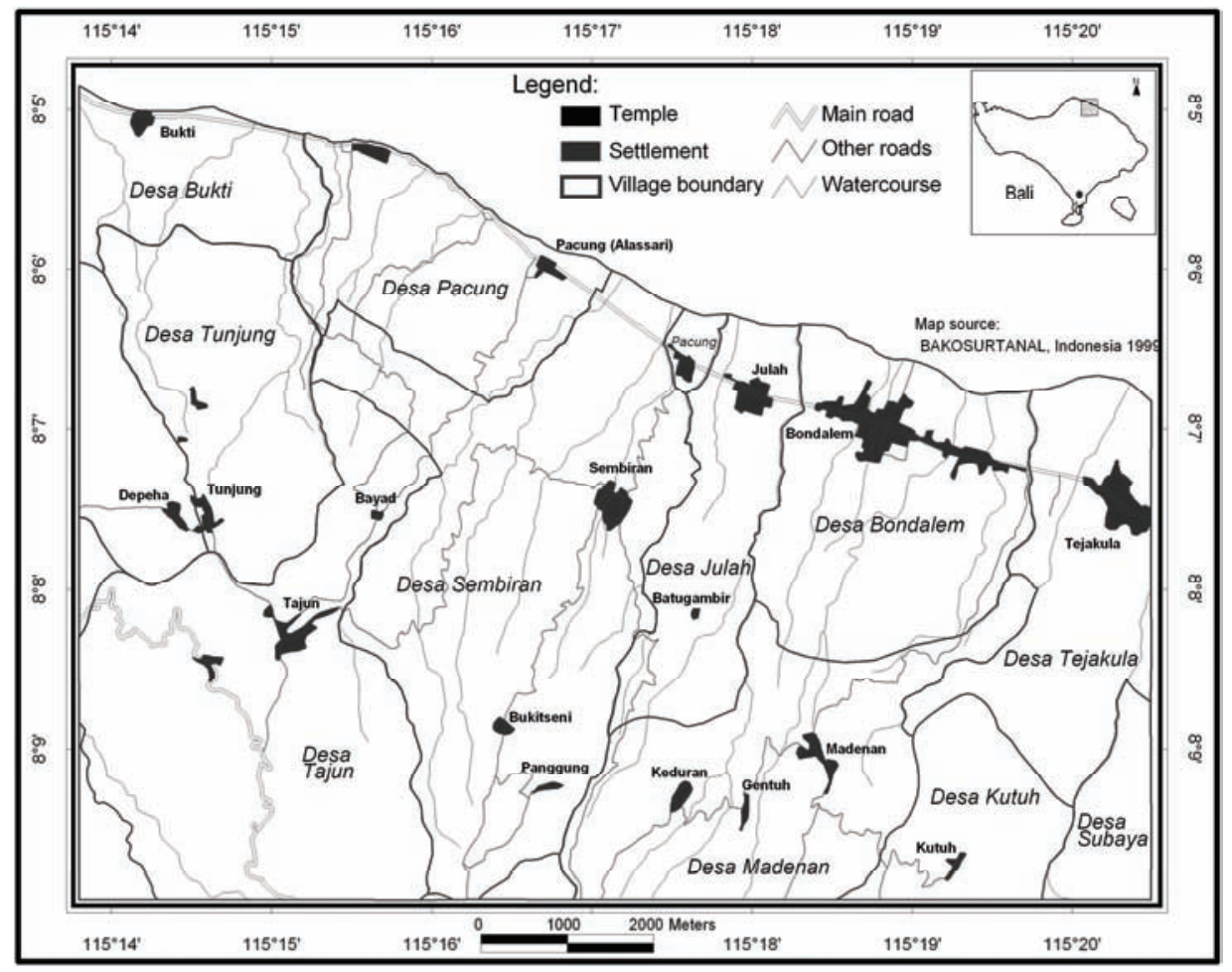

Figure 1: The research area on Bali's north coast, Kecamatan Tejakula, Kabupaten Buleleng.

In popular as well as academic writing since the 19th century, these villages have been described as a survival of an ancient, somewhat mysterious culture, allegedly originating in a pre-Hindu era and still displaying "animistic" features. They were labelled (together with a couple of other mountain villages) as Bali Aga, OldBalinese. They were assumed to have remained untouched by the culture of those immigrants in the $16^{\text {th }}$ century from East Java who fled to Bali after the mighty Hinduized kingdom of Majapahit collapsed due to the advent of Islam. The aura of a aboriginal culture is expressed also in today's international art market where all kinds of textiles allegedly of true Sembiran origin fetch exorbitant prices (see Nabholz-Kartaschoff this volume). 
It therefore seemed tempting to investigate these villages on the North Coast, with their social and religious life, from an ethnohistoric perspective: are there any traces that relate to any of the earlier periods documented by archaeological artefacts or the copperplate inscriptions? How far can we assume continuity, and to what extent do we have to consider change? Conversely, can the study of today's culture contribute to the understanding of earlier practices mentioned in the inscriptions, such as the obligations of the villages to deliver offerings and goods at set dates at temples and other institutions (see Hauser-Schäublin this volume), or the veneration of ancestors (see Patera this volume) or burial practices (see Drawatik this volume)?

There is no simple answer to the questions of continuity and change. Neither one excludes the other. Rather, as this book will show, both are intertwined in complex processes through time.

The academic concept of history as used in this book is based on the notion of continuous processes that take place between actors themselves as well as between actors and their environment, thereby continuously producing modifications of existing practices and beliefs, though to differing extents and at different tempos. Some practices and beliefs may change faster than others, some may come to an end, others are newly created or introduced or adapted from the outside and meanings may gradually or abruptly shift.

Nevertheless, there are material artefacts that were once created and may persist unaltered for centuries depending whether or not they were exposed to factors of natural decay and/or human use. One category of the most exciting objects that have inspired the imagination of many scholars are those called "megalithic", menhirs, step pyramids and the like, of which many existed in Sembiran until recently. However, these megalithic monuments, often taken as proof of Neolithic culture, are difficult to interpret in terms of date of origin, their actual age and the question of continuity.

Though many factors that have to be considered when discussing cultural issues through time may be roughly determined, many unknown factors related to social interactions have to be taken into account as well. However, the type of factors, the way some became more influential than others, and the extent to which they caused change or not are impossible to estimate. The most evident factors of change are those related to the environment and ecology. Over the past one thousand years the environment has dramatically changed - and with it of course the modes of subsistence (see Kalb this volume) with noticeable consequences for social organization.

Other factors - to start with, epidemics that several times must have devastated and emptied whole strips of land - human agency and social interactions of various kinds are almost impossible to ascertain. The geographic location of these villages as such, more or less right on the border of the sea, suggests vivid interac- 
Hauser-Schäublin and Ardika „Introduction“

tions of all kind, attacks, fights and perhaps even wars, trading activities, the advent of men of knowledge, missionaries, immigrants, refugees and many others. We have evidence of a number of factors at certain times over the past 2.000 years, but these allow us just a glimpse into dynamics that must have been, to various degree, continuously at work. Thus, the inscriptions, for example, give evidence of almost regular plundering of the villages and the villagers fleeing to settlements up in the mountains, such as Upit (see Setiawan and Rochtri this volume). Oral histories and ritual practices testify to intense interaction with bypassers and immigrants. There are strong indications that the villages on the North Coast were rarely culturally homogenous settlements even in the most ancient times. Among these indications are the apparently different burial practices that Ardika and his team discovered already for a time 2.000 years BP (see contributions by Ardika, Suastika and Drawatik).

Of course the location of these villages in the context of social networks, too, explains why the internal as well the external dynamics to which Julah, Sembiran and Pacung were exposed and to which they themselves actively contributed for a long time, were so vigorous: They were situated on one of the major trade routes from China, India and beyond to the Spice Islands (spices from the Molukku were highly valued already among the Romans) that apparently goes back to the first millennium B.C. (see Ardika and Suastika this volume) with foreign traders from India already reaching this tiny spot in Bali (see Ardika this volume). Thus, far from being isolated, closed communities, these villages and their past seem to be a patchwork rather than a 2.000 years old undisturbed autochthonous culture.

This book sums up the different kinds of research that have been carried out so far in the villages of Sembiran, Julah and Pacung. They all give evidence of the rich cultural life in these villages, which during certain periods could even be described as cosmopolitan. Among the archaeological evidence were also bronze objects such as a kettledrum (nekara) related to the so-called Dong-Son bronze work with its characteristically shaped artefacts that originated in today's northern Vietnam in the second millennium BC (Bellwood 1985:272). Many other artefacts testify to direct contact with India and China; foreign trading communities located nearby are mentioned in the copperplate inscriptions (see Setiawan this volume). Oral histories also tell of wars in which the villagers had to participate such as the war the famous king of Buleleng, Panji Sakti, led im Blambangan, East Java. Others tell of early contact and dealing with Islamic immigrants in the $17^{\text {th }}$ century which substantially changed the religious and social organization of the villages.

When the first Dutch visited Julah and Sembiran they knew nothing of the rich past of these villages. They had to rely on what they saw and what they were told. These villages were labelled "Bali Aga", aboriginal Balinese, by those Balinese who thought of themselves to be descendants of the highly praised kingdom of Majapahit. The myth of the "aboriginal Balinese" has persisted ever since; this book, however, offers a new perspective based on a broad range of archaeological 
and historical evidence that proves a past very different from the popular assumptions of "Bali Aga".

This book, and some of the research on which this publication is based, could not have come into existence if there had not been sponsors who supported our efforts. We should therefore like to thank Universitas Udayana, Denpasar/Bali, The Balai Arkeologi Denpasar, The Pusat Penelitian Arkeologi Nasional in Jakarta, Kasi Kebudayaan Kecamatan Tejakula, para Kepala Desa (the village's head) of Pacung, Sembiran and Julah, the Lembaga Ilmu Pengetahuan, Jakarta, for the approval of our research in Bali, the University of Göttingen, Germany, for its material and personal support, and the German Research Council (DFG) in Bonn for all the grants that allowed both the ethnographic and archaeological research and also the publication of this volume to take place. We would like to thank Dr. Marie-Luise Nabholz-Kartaschoff (Basel), Prof. Dr. Dr. Michael Schultz (Göttingen), Prof. Dr. P. M. Grootes and the Leibnitz Laboratory for Radiometric Dating and Stable Isotop Research, University Kiel; they all have contributed their expertise to this volume.

And of course we are grateful also to all the Balinese people who in one way or the other supported our endeavours to bring light into the past of these villages on the North Coast.

Denpasar, April 2007 



\section{Looking Back in Time}





\title{
Sembiran and Julah - Sketches of History
}

\author{
Brigitta Hauser-Schäublin
}

\section{Introduction}

Sembiran village numbers about 5.000 inhabitants today. It is located high above the nearby shore line. Its territory spreads from the beach up to the coastal mountain range. The landscape consists of extensively cultivated ground with no forest left. During the dry season, from May to November the whole area looks brownish and dry (see Kalb this volume). The trees lose their leaves, the crops in the garden dry up, and drinking water, conducted by pipes from a privately owned well in the mountains of Bangli regency ${ }^{1}$, is no longer available. ${ }^{2}$ During the rainy season, from December to April, the picture completely changes with lush vegetation everywhere. But most of the time, the rainy season is too short to grow even maize; in many fields it is mostly tubers as the major food crop that are nowadays cultivated. In the 1880s Liefrinck mentioned that rice was regularly grown in Sem-

\footnotetext{
${ }^{1}$ This well, essential for the survival of the village, is today located in Bangli regency. Apparently the southern border between Bangli (whose king collaborated with the colonial power) and Buleleng was drawn by the Dutch in 1884 (Liefrinck 1934:65). It is an open question whether the well was once on land owned by Sembiran or already in the possession of Satra village at that time. The first water pipes were established in 1963 (Lansing 1977:198).

2 In 2006, a new water supply system - water from wells near the shore being pumped up to the village - was built. However, since fuel became more and more expensive, the pumps were not in use. Nobody could afford to buy water at prices almost as high as bottled water.
} 
biran (1934:68), though apparently in dry fields only. ${ }^{3}$ However, the cultivation of rice in dry fields ended several decades ago. Over the past 100 years subsistence economy has considerably changed, as has the whole way of living. Bundschu described Sembiran as "an oasis of blossoming tangerine trees" in the 1980s (1994:150); this cash crop provided the peasants with a regular income and even some wealth. ${ }^{4}$ However, in the 1990 s the tangerine trees became infected with a virus that proved untreatable. Most of the trees died and the rest had to be cut down in order to stop the spread of the virus. ${ }^{5}$

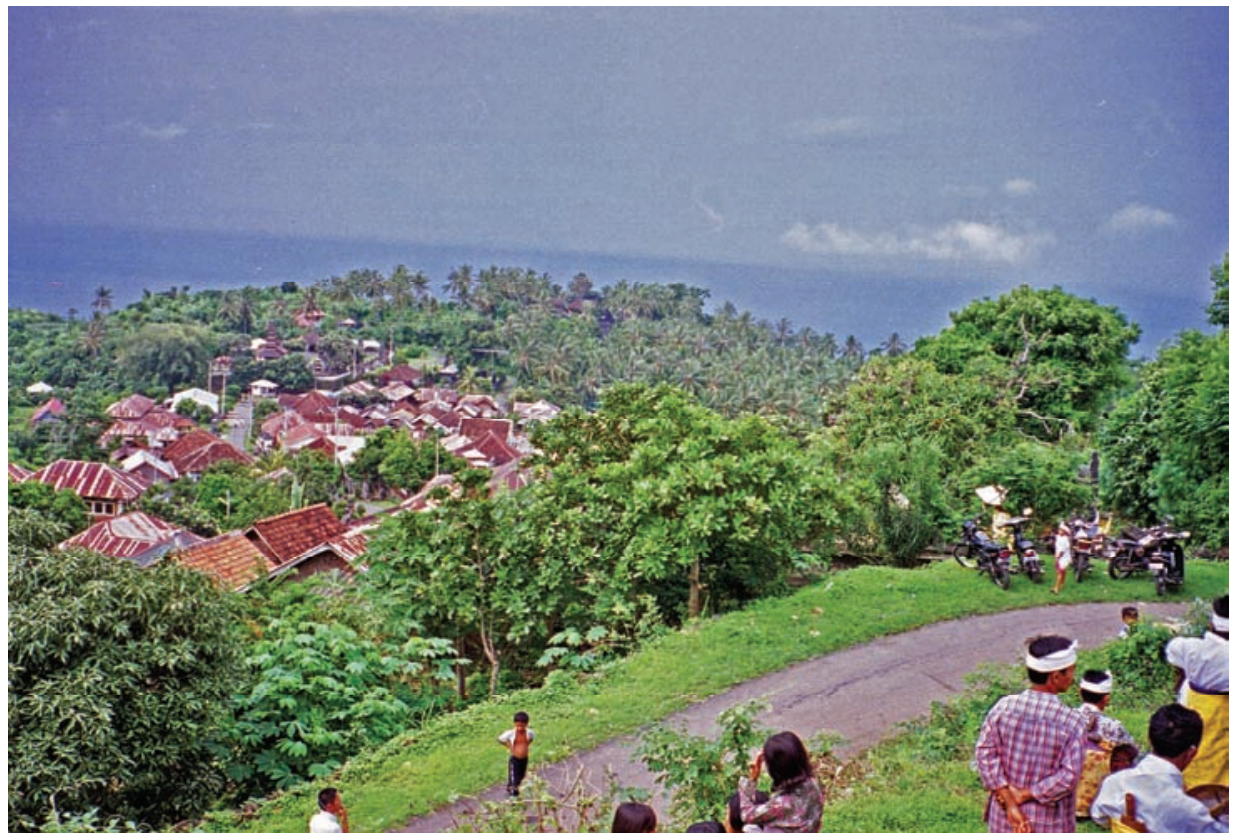

Photo 1: View from the top of Sembiran to the core village located on a hill above the sea.

Photo: Brigitta Hauser-Schäublin 1998.

Today, life in Sembiran has become difficult; many of the inhabitants live in poverty. Most of the fertile land along the shore, where abundant water is available, and up in the mountains, where rain regularly falls, is no longer in the hands of the core villagers. Main parts of this best agricultural land has been sold to people from other villages or to immigrants who now live high up in the mountains (Ban-

\footnotetext{
${ }^{3}$ The peasants of Sembiran were forbidden to irrigate their fields in the $19^{\text {th }}$ century (Liefrinck 1924:383).

${ }^{4}$ Lansing reports that the total value of the harvest of fruit trees was 94.091 .000 Rupiah or US\$227.272 in 1975 (1977:199).

5 There are almost no more tangerine trees left - except high up in the mountains, where it seems that the virus is unable to exist.
} 
jar Gunung Seni, Banjar Panggung), once isolated places and difficult to reach. Today, people living there cultivate cloves, coffee and cocoa - cash crops that do not grow in lower and hotter altitudes. Without the remittances from the hundreds of emigrants who left Sembiran in search for a better life elsewhere, and now live and work in other parts of Bali or in Java, life would be much harder. Without regular food supplies (mainly rice) provided by the Indonesian Government many families could not survive.

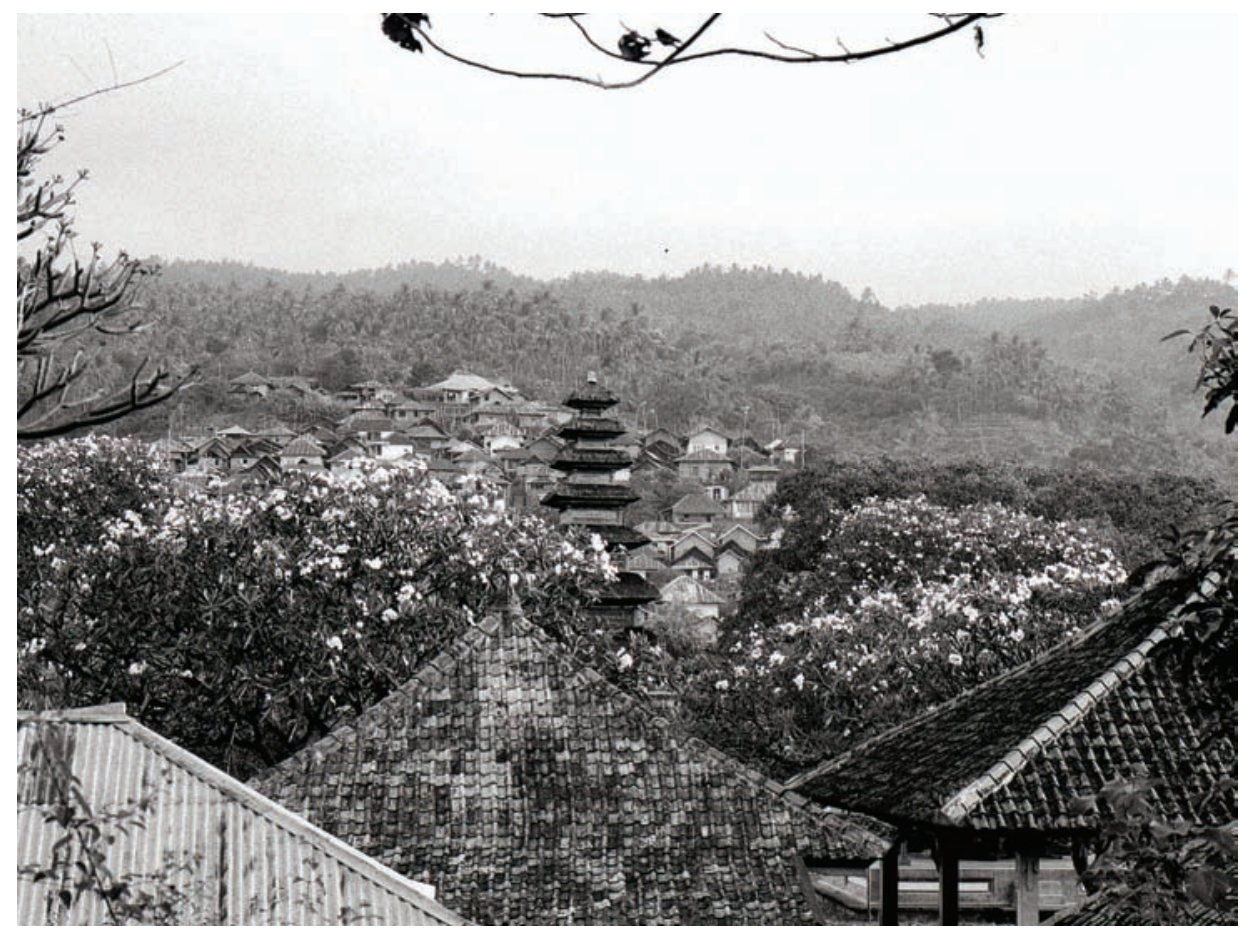

Photo 2: View from the lower end of Sembiran; its vast territory reaches up the mountains.

Photo: Jörg Hauser 2001.

Originally, my interest in carrying out investigations in Julah and Sembiran - villages that seem to have common historical roots, was reinforced by those publications in which they were labelled as "ur-Balinese" or Bali Aga, villages, where religion was not yet dominated by Hinduism but was still more ancient, and where the social organization seemed to be untouched by caste-like stratifications (Liefrinck 1934:65-66). However, the so-called "Sembiran inscriptions" - royal edicts issued between the $10^{\text {th }}$ and the $12^{\text {th }}$ century and written on 20 copperplates - were translated only after Liefrinck's publication in which he made the "Bali Aga" assumption. These "Sembiran inscriptions" consist of six different royal edicts classified 
by Goris (1954) as follows: "no. 104 Sembiran A I" dated saka 844 (AD 922)6, "no. 201 Sembiran B", dated saka 873 (AD 951), "no. 209 Sembiran A II", dated saka 897 (AD 975), "no. 351 Sembiran A III", dated saka 938 (AD 1016), "no. 409 Sembiran A IV" dated saka 987 (AD 1065), "no. 621 Sembiran C" dated saka 1103 (AD 1181). Today, 10 plates are kept in Sembiran, 10 in Julah. These copperplate inscriptions were royal edicts issued by changing kings whose seat seemed to have been somewhere inland, probably in the Batur caldera. ${ }^{7}$ These edicts were explicitly addressed to the villagers of Julah. In the earliest inscription (saka 844) The translation of these texts (written in Old Javanese and Old Balinese with many Sanskrit words) revealed that Julah had been a highly stratified and complex society; the $12^{\text {th }}$ century inscription makes clear that Julah was part of a mandalic state, "Balidwipamandald" or one of seven states "sapthanagara". People of different social standing (candla or caste) such as Brahmana, Gusti as well as foreigners, juru kling, were then living in Julah. There were priests and hermits (bbiksu) of different denominations (among them Siwa and Buda, with titles such as pendeta, mpungken cewasogata, rsi) living nearby. In the earliest inscription (saka 844), Julah's environment is described as prosperous with irrigated rice fields, water buffaloes and forests nearby. In the royal edicts (dated saka 844) there is even mention of a kind of black slate, sila, which seems to be identical with the black stone that naturally occurs and is today exploited and sold for the paving of paths and bathroom floors. Today's Julah is located at about the same place as the historical one. Nevertheless, it would be a mistake to give into the assumption that continuity in site and name reflects continuity in population or culture too (see below), since these inscriptions hint at rapid transformations that already took place between the $10^{\text {th }}$ and $12^{\text {th }}$ centuries.

Nevertheless, the myth of Sembiran as being a survival of pre-Hindu or rather aboriginal Bali - the Bali Aga - persisted even among anthropologists (see Hauser-Schäublin 2004b). Accordingly, when I started my fieldwork in 1995 I assumed that these villages had been little touched by outside influence during the last few centuries. However, the longer I stayed in the area, mainly in Sembiran, I realized that both villages had been continuously subject to change that had at times been rapid and radical. This is not surprising if we consider their prominent location bordering the sea. For at least two thousand years one of the most important trading routes that linked India and China to the Spice Islands touched the north coast of Bali as well. Julah was one of the major ports, at any rate during the time covered by the royal edicts mentioned (see below).

Although the royal issues were no longer written on copperplates after the $13^{\text {th }}$ century and the royal seat must have been moved to the Southern plains around

${ }^{6}$ The saka year is of Indian origin. The date saka 844 is equivalent to AD 922; thus there is a difference of 78 year between the two calendars.

${ }^{7}$ Reuter locates one of the royal sites, called Singhamandawa in king Ugrasena's edict (AD 922), on a hilltop near Sukawana (Reuter 2002a:92). 
that time, boats and ships from other places of Southeast Asia and beyond continued to pass. As it turned out, Julah must have periodically suffered plundering by pirates until the arrival of the Dutch. Moreover, notions of the "preHinduistic" condition that is said to have prevailed in these "Bali Aga"-villages in the $19^{\text {th }}$ century are contradicted by oral histories and material traces. This evidence demonstrates that Muslim immigrants had many centuries ago set foot in both Sembiran and Julah villages and left Islamic imprints on their culture (see Hauser-Schäublin 2004c). Additionally, plagues such as cholera that had been brought to these coastal villages by seamen threatened them several times with extinction. In sum: the two villages and their culture do not display features that have survived since time immemorial.

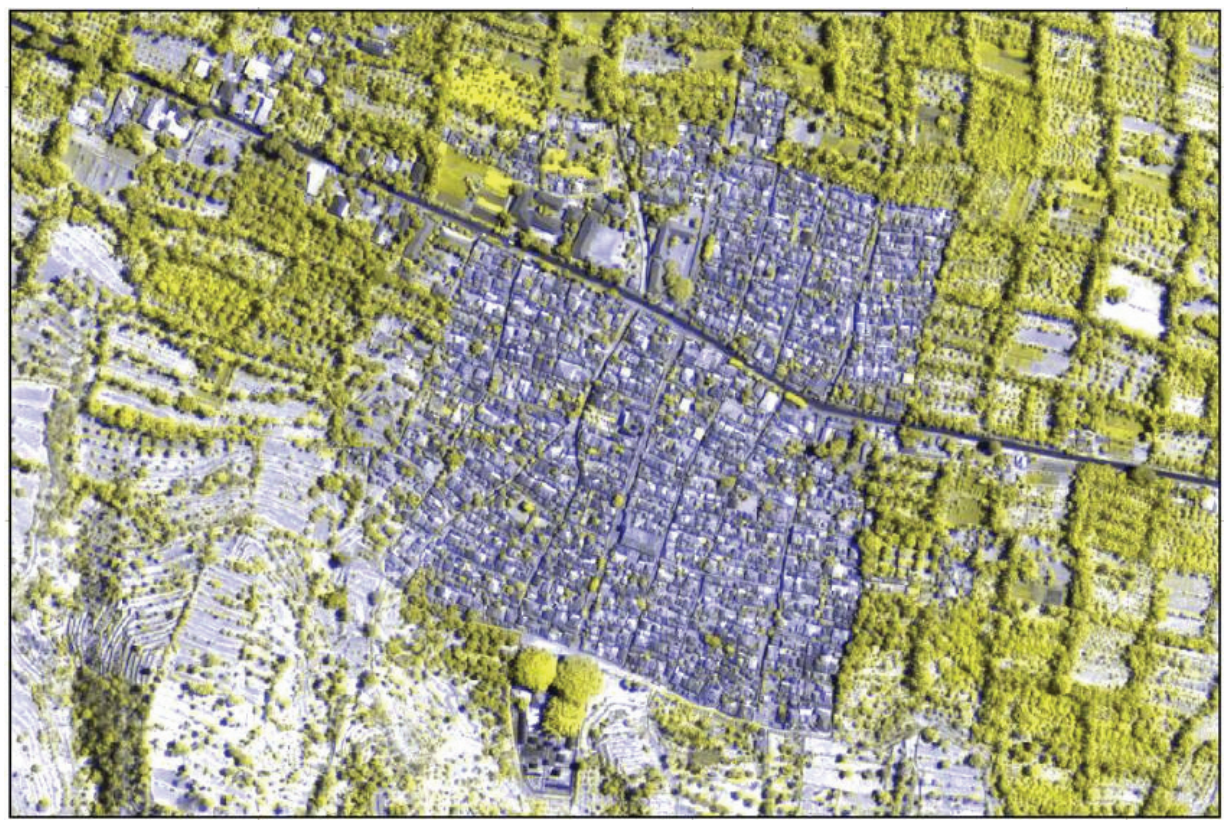

Photo 3: Satellite image of Julah with the main road dividing the village into two parts. Note the garden patches on the right upper (north-eastern) corner and the main village temple with three huge banyan trees in the lower centre of the image, 2003.

It was Liefrinck, the Dutch Controleur of Bali, who was among the first to set foot in Sembiran. He 'discovered' the copperplates and made copies of them (Brandes 1890:17). The village elders did not know that these "Ida Bhatara", these sacred icons, were inscriptions. Liefrinck noted with surprise that none of the inhabitants was able to read or write even contemporary Balinese in the $19^{\text {th }}$ century. Therefore, all village matters remained undocumented in writing. The list of 
the members of the village association consisted of a basket with stones, each stone representing a member (Liefrinck 1934:67). The ritual elder, bahan, in charge of allocating communal tasks to the individual members had a tally stick, about two and a half metres long, on which the order of the individual members according to seniority was marked (Liefrinck 1927:276). The former illiteracy of the inhabitants (today there are many academics and successful business men, too, who were born in Sembiran) contributes to the difficulty in finding documentation of Sembiran's past. Nevertheless, social change and an eagerness to adopt new ideas and practices do not imply that everything of the past has completely disappeared.

How to investigate Sembiran's and Julah's past if periods of fundamental change call into question any continuous tradition?

In this article I shall attempt to write a kind of sketch of Sembiran's and Julah's past by using archaeological evidence, the content (translations) of the copperplate inscriptions ${ }^{8}$ as a backdrop against which I shall present data from my own fieldwork (between 1995 and 2006) in order to provide a comparison where this seems reasonable. I shall rely on three types of sources that I was able to distinguish during my anthropological fieldwork: 1) the spatial organization of the village and its temples, 2) the ritual practices, and 3) oral histories. The latter differ from the first two in so far as they are much more subject to the agency of the individual story teller - and also his and his audience's wish to represent and reshape the past according to new stories heard, read, seen (in TV programs) and taught in school. Nevertheless I will take the oral histories as sketches of Sembiran's past. People equated these oral histories in many respects with history in a Western sense; I will therefore not make an a priori distinction between stories (or histories) and history, although I shall raise the question as to how far some of the stories mirror events and processes that have taken place some time in the past.

These three types of sources will be supplemented by colonial literature on Julah and Sembiran that starts in the mid-19 th $^{\text {ch }}$ century; written evidence therefore already covers a period of 150 years. Only for this last period would it be possible to put up a kind of chronology; for all other historical evidence this is, with few exceptions an almost impossible task.

I will start with highlighting ethnoarchaeological evidence (see Ardika, Suastika, Setiawan and Rochtri this volume) only as far as necessary for the further understanding of this contribution. In a second step I shall present indigenous perspectives of origin mainly as told in oral histories. I then proceed to an analysis of social space, mainly the village structure and its major temples. A further chapter

${ }^{8}$ Goris 1954, Ardika and Beratha 1996, 1998 and Ardika this volume; see also Setiawan this volume and the transcription and translation of all "Sembiran inscriptions" in the appendix. 
deals with Sembiran's regional temple and ritual networks in a historical perspective.

\section{Ethnoarchaeological Evidence - An Overview}

According to the copperplate inscriptions, Julah was a major port village with an international market place during the $10^{\text {th }}$ and $11^{\text {th }}$ century. Its importance certainly stemmed from the fact that North Bali was touched by the trading route to the Spice Islands (see Ardika and Setiawan this volume). According to the seasonally shifting trading winds, ships from or to India and China anchored at Julah, then a fortified village, kuta. The foreign merchants had, as the inscriptions state, their own distinct settlement nearby. Julah was also a trading centre for goods brought by ships from abroad and transported from there inland (and vice versa). Ardika's long term excavations (see Ardika this volume) in the coastal area between Julah, Pacung, Bangkah and Sembiran have revealed testimonies of regular contact between India and Bali that are already one thousand years earlier than the era documented by the copperplate inscriptions. The most important data yielded by Ardika's excavations, apart from the many goods of Indian origin found in graves (Ardika et al. 1997), are certainly the skeletons of people who pronanly were of Indian origin (Lansing et al. 2004; see Ardika and also Schultz this volume). This proves that the goods traded between India and Bali were not the result of indirect but rather of direct contact by Indians travelling as far as Bali already more than 2.000 years ago. In several respects, we can therefore assume continuity in trade relations for a period between $1^{\text {st }}$ century B.P. and the $10^{\text {th }}$ century AD.

What has not yet been determined so far is the exact location of the harbour. While in Julah no indications in oral histories exist, I was told in Sembiran that "the older generation" formerly often spoke of a harbour located where today a temple (Pura Sang Hyang Marek) stands right on the edge of the sea, as you can see in Figure 1. In Pacung, people reported to me that the strip of land west of this temple is still called pabean, harbour with a custom's office, or in this case perhaps rather a harbour under surveillance of a subandar.

This harbour, I was told, once was a "market-place with merchants coming as far as Europe trading there". Since erosion proceeds quickly and the shore line continuously shrinks (a reverse process apparently took place some centuries ago) it is difficult to make out or find evidence of the precise site. ${ }^{9}$ The location nevertheless makes sense since it is just beside the estuary of a (currently dried up) river (Yeh Lengis) that would have allowed transport of goods by boat from or to the hinterland ending near Pucak Sinunggal, which was an important site as early as

\footnotetext{
${ }^{9}$ If any traces of such a harbour remain, it would be necessary to carry out under-water archaeology.
} 
the $10^{\text {th }}$ century (see below) near today's village of Tajun. The regional temple of Ponjok Batu west of Pura Sang Hyang Marek is built on a prominent spot, a rocky headland with some big stones in front of it. Many oral histories report that Chinese boats stopped there. Judging from the excavations it was a rather long strip of land along the shore which was in use in the first century B.P. and probably still at the time documented by the copperplate inscriptions.

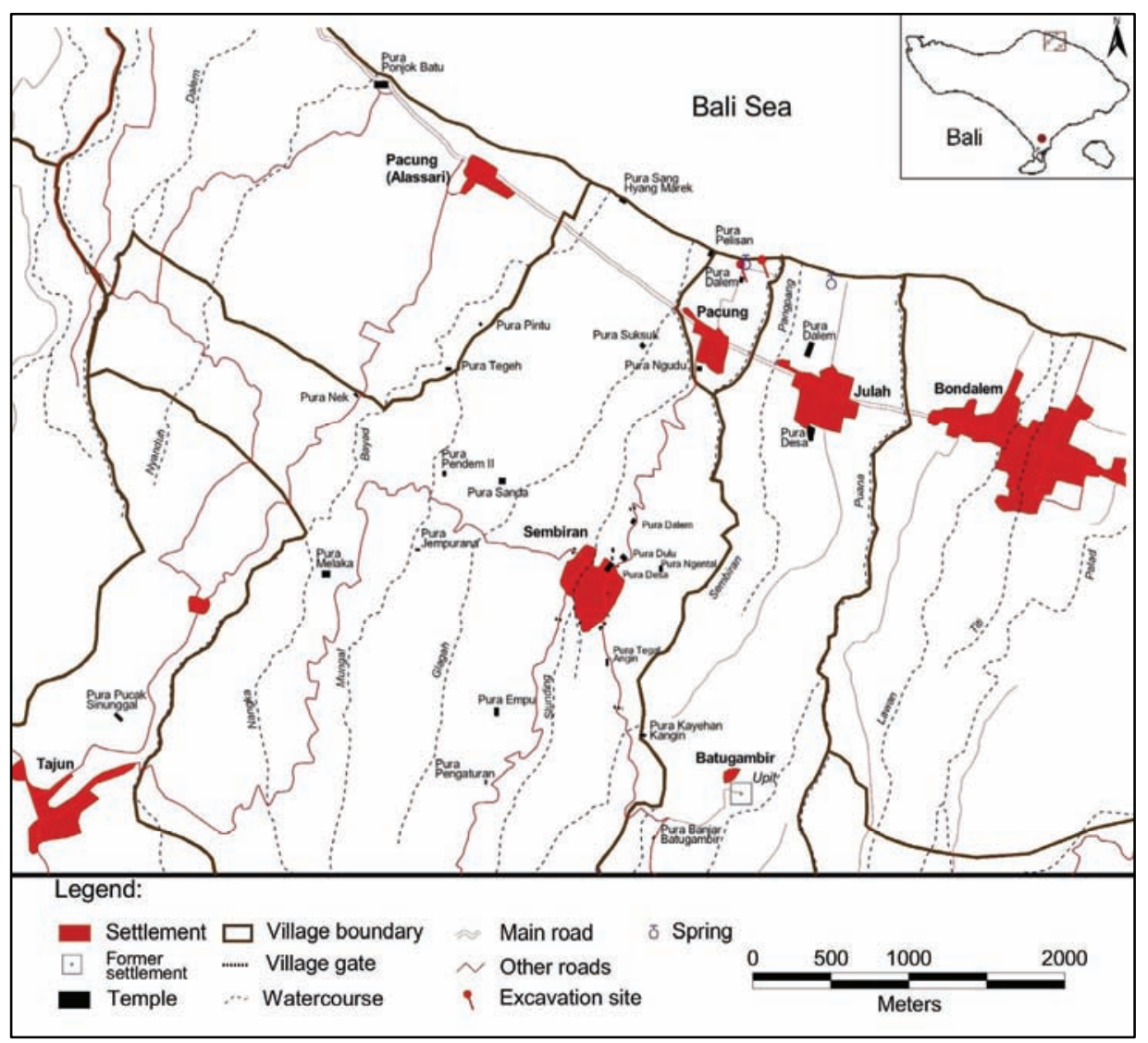

Figure 1: The main research area and neighbouring villages. Cartography: Enrico Kalb 2005; source: BAKOSURTANAL 1999.

Since the locations of the warehouses, the foreign merchants' settlements, the fortified settlement, the market place and many other specialized sites may have shifted over time, excavations do not permit us to locate them definitely - with the exception of the burying grounds.

In his edict (no. 209, Sembiran A II, saka 897) King Warmadewa admonished the inhabitants of Julah to keep the major roads used for the inland transportation of 
the goods in good condition. His (unknown) predecessor (no. 104 Sembiran A I, saka 844 ) had already attached great importance to Julah and the obligations it had as a port settlement. He ordered that the surviving villagers, who had fled to the mountains after their village had been raided and plundered by pirates, should return to the fortified settlement. The safeguarding of the port, the warehouses, the settlements of the visiting merchants and the marketplace was a precondition for the functioning of such an international harbour and its reputation.

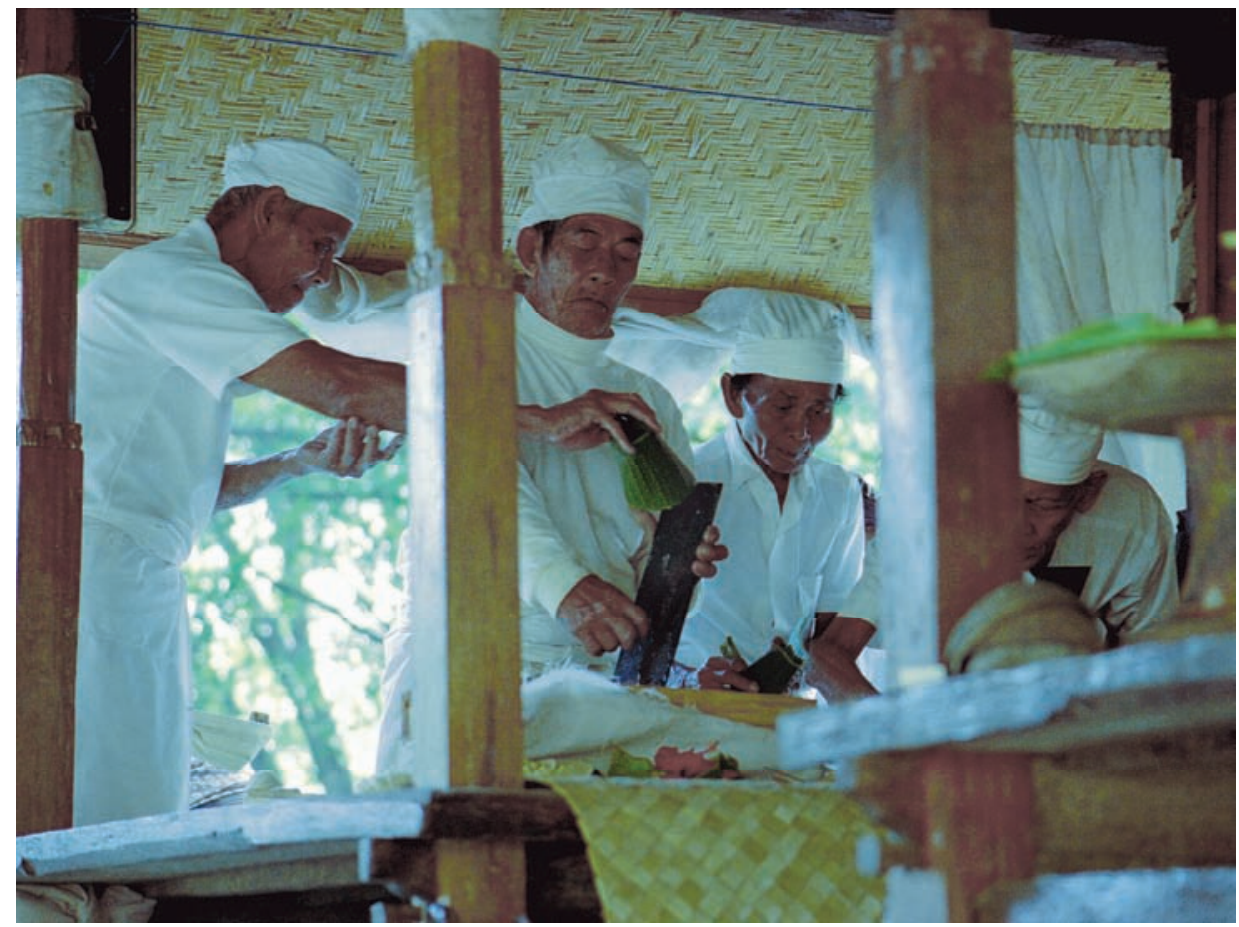

Photo 4: The ritual cleansing and anointing of the copperplate inscriptions by the ritual leaders, kubayan, in Julah. These copperplates are worshipped as sacred and deified heirlooms.

Photo: Brigitta Hauser-Schäublin 2001.

Some of the commercial ships landed at the port and replenished their supplies there. Of great importance was apparently the fresh-water well in the immediate vicinity of the shore-line already mentioned in King Warmadewa's edict of saka 897. This well and its bathing-place still exist today.

The six copperplate inscriptions covering roughly two centuries illustrate how fast the social and political conditions in which Julah was embedded changed. While in the $10^{\text {th }}$ and the early $11^{\text {th }}$ centuries the village was of predominant commercial value for the king and his realm, the situation seemed to have dramatically changed in the second half of the $12^{\text {th }}$ century. King Sri Maharaja Jayapangus who 
issued the saka 1103 edict (no. 621, Sembiran C) emphasized Julah's strategic importance in the context of military attacks from the outside. Instead of a port, Julah is called a "fence of the state" ("Julah pinaka pagar ida di nagara") with the king's troops stationed there on stand-by. It was for this reason that king Jayapangus relieved the villagers of almost all taxes.

From the beginning of the $13^{\text {th }}$ century, no further inscriptions directly concerned with Julah have been preserved, meaning that almost nothing is known of Julah's (and Sembiran's) fate up to the 19th century when colonial sources start.

The name Sembiran is not listed in the inscriptions. How old or how recent the name is - people both in Julah and Sembiran hold that Sembiran was formerly called Gunung Sinigia, or Sipapan - cannot be determined. In both villages, oral traditions substantiate the fact that Julah and Sembiran were once closely related, probably at a time as far back as the era documented by the royal edicts. In oral tradition Julah is described as a male sibling gifted with the spirit of a daring male who is not afraid to live right on the border of the sea, ready to face its challenges. By contrast, Sembiran is described as Julah's sister since women shy away from martial challenges. To live up a steep hill, which was formerly covered by a dense forest difficult to penetrate, was much safer. Sembiran was once probably a place where religious dignitaries lived (perhaps in one of the monasteries, petapanan, mentioned in the inscriptions) that closely interacted with the inhabitants of Julah. Over the centuries, Julah was, in contrast to Sembiran, raided frequently by pirates as the inscriptions as well as the oral traditions document. Each time the survivors fled up the hills and built a settlement in Upit (see Setiawan and Rochtri this volume), which is today a banjar of Julah that has been a resettlement place for migrants from Lombok and Karangasem since the mid-1900s.

Julah was also raided in the centuries immediately preceding Dutch colonial control. We can gather from oral traditions that the inhabitants of Julah who were once again living in Upit returned to the coastal area probably in the late $18^{\text {th }}$ century and constructed the village at the site where it is still today..$^{10}$ During the time the refugees lived in Upit they held their monthly meeting at tilem (the moonless night) in the village temple of Sembiran together with the krama desa (village association) of Sembiran. Sembiran had its own meeting only a day later (patipanten). These communal meetings of Sembiran and Julah ceased when the refugees decided that it was safe enough to stay near the coast again. Still today, Sembiran holds its meeting not on tilem (as is usual in most villages) but on patipanten. The

\footnotetext{
${ }^{10}$ One of my major informants claimed that he was the $13^{\text {th }}$ generation after his ancestors moved down from Upit. The return to the coastal site is annually commemorated by ceremonies carried out on two subsequent days. The first is called sugu-sugu, celebrating the homecoming. During the second ceremony, jaga-jaga, carried out on the following day the children and adults produce a lot of noise by clapping stones. This ceremony is intended to demonstrate fearlessness and the readiness to strike back against attacks from the sea (pirates).
} 
"void" day reminds the inhabitants of Sembiran that this was the day for the meeting of both villages.

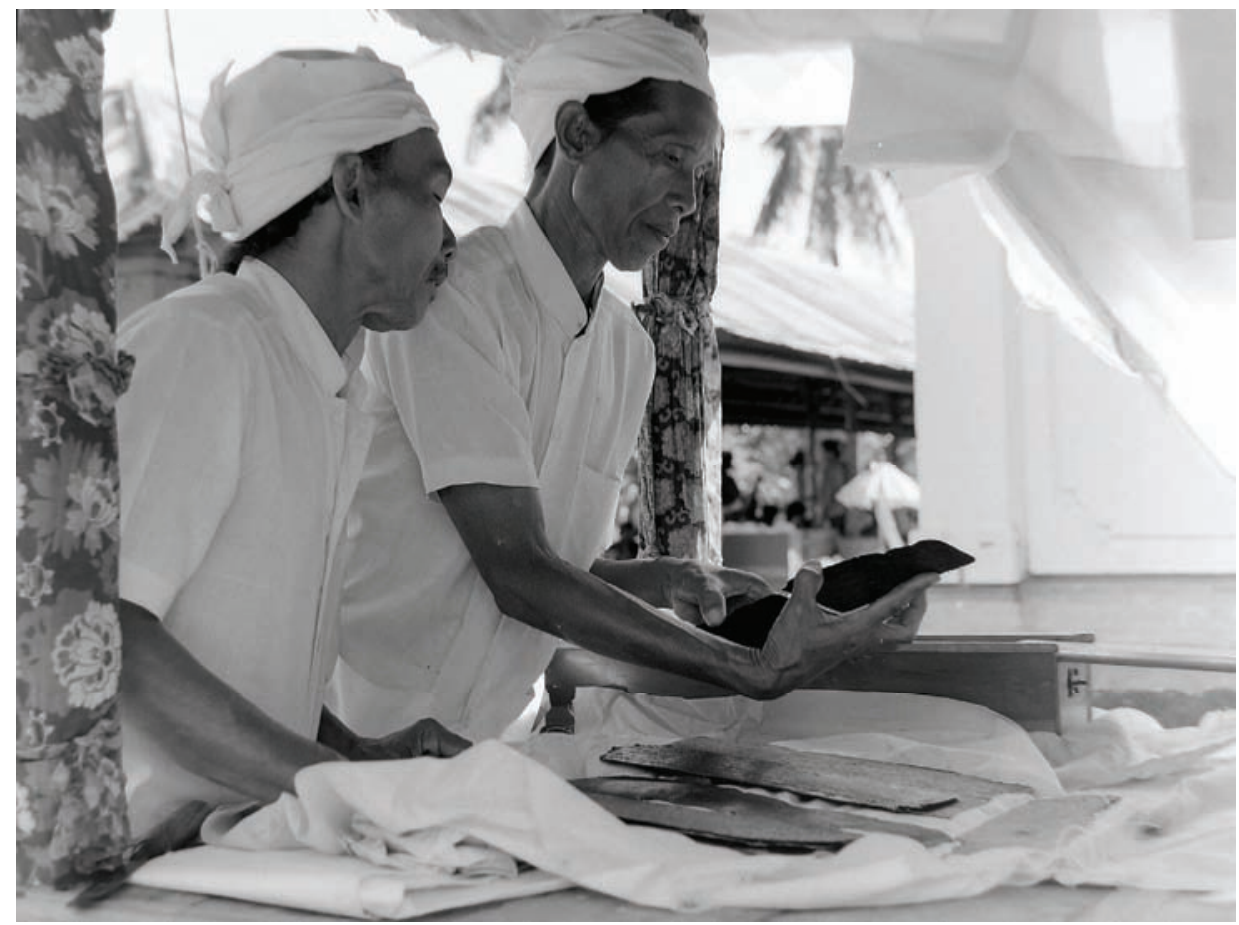

Photo 5: Two temple priests inspect the copperplate inscriptions during one of the major temple rituals in Sembiran.

Photo: Jörg Hauser 2001.

Before, when the inhabitants of Julah were still living in Upit, all the copperplate inscriptions - all of them deal with Julah - were kept in Sembiran where Liefrinck met them. They were kept hidden in a cave in a deep and formerly densely forested ravine outside the village. Only some time after Julah had resettled the coastal site did the two villages divide the plates, sometime between the 1880s and 1960s. ${ }^{11}$ Since then 10 are kept in Sembiran and 10 in Julah.

Due to the bonds of siblingship that exist between Sembiran und Julah, intermarriage between the inhabitants of the two villages is still forbidden because this would be considered incestuous.

${ }^{11}$ Goris and Poeger noted in 1965 that the copperplates had been divided between Julah and Sembiran, each of them holding 10 plates. There exists no memory as to when or how this division took place (see Ardika 1991:219). 


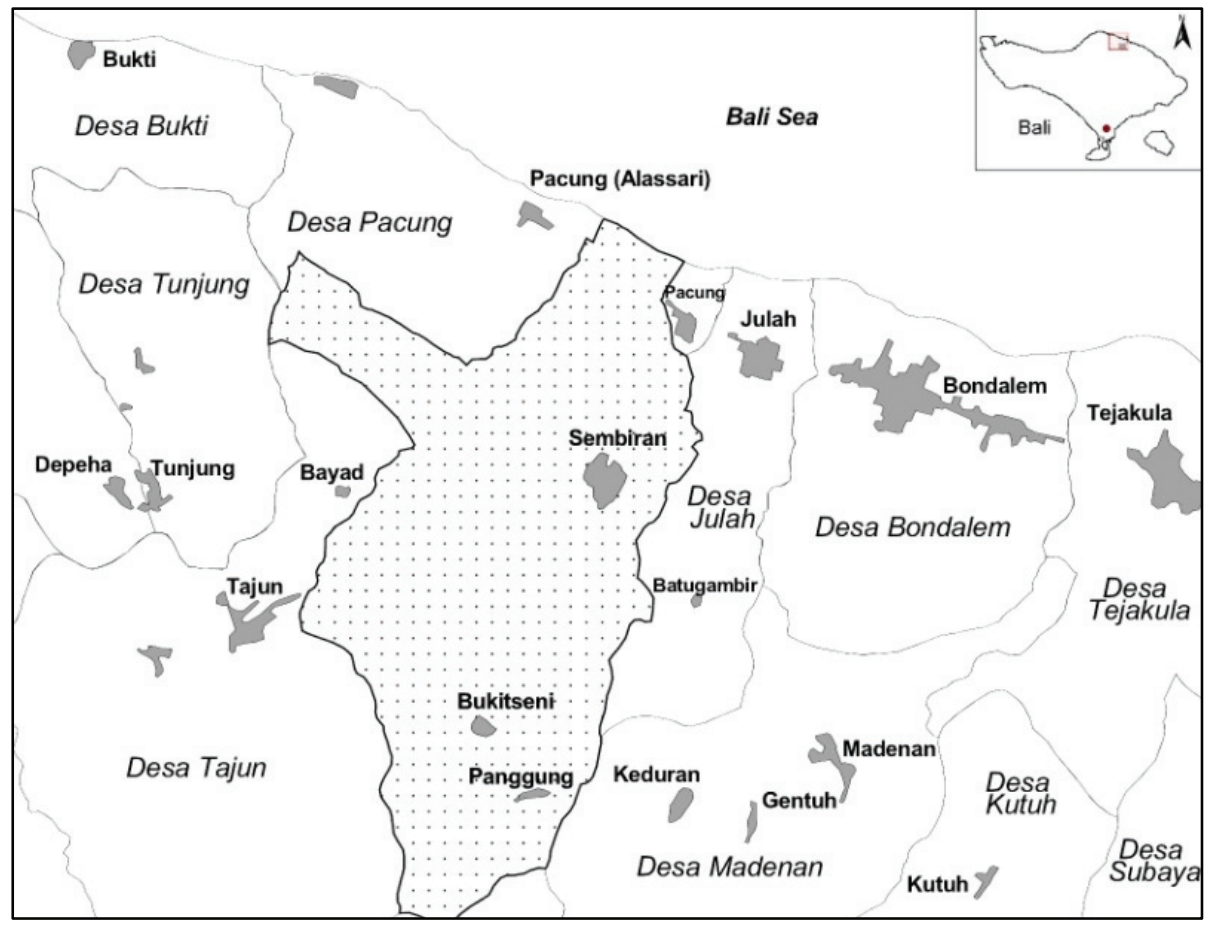

Figure 2: Sembiran village territory and the location of the neighbouring villages.

Cartography: Enrico Kalb 2005; source: BAKOSURTANAL 1999.

The neighbouring villages of Pacung (see Patera this volume) and Bangkah (nowadays called Alasari) are closely related to both Sembiran and Julah. It is said that the land of Pacung and Bangkah formerly belonged to Julah and Sembiran. Both places, Pacung and Bangkah, are, from the perspective of Sembiran, seen as suitable for outcasts. An old man in Sembiran told me the story of how he had had to leave Sembiran and move down to the outskirts of Pacung when he and his wife gave birth to four daughters only and no son. They lived there for several years in misery. Finally, a son was born to them and they were allowed to return to the main village. The other reason why people had to move to Pacung was when a man committed incest such as, for example, marrying his own niece (Liefrinck 1934:330) or any other close relative. According to oral traditions told in Sembiran and Julah, this is how Pacung came into being. ${ }^{12}$ There are two temples located on the shore of the sea which are used by both villages, Sembiran and Pacung: Pura

12 There are many indications that, at least over the past few centuries, the history of Pacung is far more complex, with many immigrants, Hindu-Balinese of noble descent as well as Muslim from different areas (Bali and beyond) coming to live there already before the advent of the Dutch (see also Couteau 1999, 2000). 
Sang Hyang Marek (see below) and Pura Pelisan, a temple used for purification rituals (especially when the village is sebel, or impure after inauspicious events, formerly after death and the birth of twins).

The people of Julah still circumambulate the northern part of its territory during one of the temple rituals (ngusaba masegeh). The whole procession then follows the course of the coast in a westerly direction, crossing today's border of Pacung entering the village west of its Pura Dalem, going up to the main road and finally return to Julah. I feel certain that this was the former border of Julah's territory. ${ }^{13}$

Bangkah is said to be the place where people, forced to leave both places, Sembiran and Julah, due to infectious diseases, especially lepers, were allowed to settle. This was the origin of Bangkah as a village.

\section{Histories of Origin: Of Dogs, Trees and Men}

Apart from these ethnohistorical and ethnoarchaeological fragments there are many indigenous stories told of how Sembiran came into being and what kind of events shaped its history. The stories told in Sembiran - among the most prominent story-tellers was Pak Sawir who died in 2000 in his late $80 \mathrm{~s}^{14}$ - deal with many different topics, of mythical as well as historical origin. These are not seen as coming in a seamless sequence of events, but approach the issue of origin from a several different perspectives. A prominent figure in several histories is a dog or rather dogs of different races. They are often depicted as being the predecessors of mankind, mediating between the material world and the world of the gods. It was the dogs who begged the gods to create humans.

One of these histories, perhaps the most fundamental, deals with the origin of the world: the gods sent dogs to the world, which at that time consisted of only a small patch of ground surrounded by an endless ocean. Through defecating, the dogs extended the patch, which subsequently grew larger and larger until it was big enough to become inhabited by other beings. The god then sent for the first birds; they created mountains and the directions of the compass, the rain, the fertile ground, the plants and again many birds that filled the air with music. Finally a man and a woman were created. The first attempt to form them out of clay and to bring them to life did not succeed. Only when they were carved out of wood did the gods, begged by the dogs to turn the sculptures into living human beings, endow the couple with a soul, with life and strength.

\footnotetext{
${ }^{13}$ Julah still owns land near the regional temple of Ponjok Batur that testifies to its former western expansion.

${ }^{14}$ I am grateful to Dr. Thomas Reuter (Melbourne) who recorded a detailed and long oral history told by Pak Sawir in Sembiran in 1994. Dr. Reuter translated it with Drs. I Nyoman Sabaraka (Sukawana village) into Bahasa Indonesia. I am indebted to them for allowing me to make use of this story.
} 
Considering the fact that until recently the veneration of huge trees was an essential part of ritual practices carried out in Sembiran, the origin of hu$\mathrm{man} /$ supernatural beings from wood is not surprising. Another history makes the analogy between humans, or rather the office holders in the krama desa, and trees explicit; here, the village organization described is more or less the same today: the highest god, Bhatara Guru (who manifests himself in the sun) called representatives of different species of trees for an assembly. The first two trees that appeared were named Kubayan Benges; kubayan is the highest office in the ritual village assembly, the krama desa. ${ }^{15}$ Bhatara Guru called further trees by names and they came in pairs like men each belonging to a specific ritual moiety; they appeared and took their assigned place. Each pair of trees that followed was junior to the preceding one.

The storyteller also mentioned two different single (that is, not paired) "trees"; he stressed the fact that each of them came individually. I suggest that these single "trees" correspond to offices of the krama desa that no longer exist in this form. ${ }^{16}$ All these trees represented different specimens and Bhatara Guru decided which purpose each could serve best: timber for the construction of houses, timber for the construction of shrines, wood for producing fire, firewood, etc. ${ }^{17}$ After the meeting the trees were handed over to the humans who were allowed to make use of them accordingly. The various offices within the krama desa reflect the principle of seniority and cooperation between (pairs of) brothers (that is, the right side and the left side within the sitting order of the Krama desa in their meeting pavilion, see below). But more fundamentally all these offices united in an association are founded on the principle of a division of labour, each office assigned with different tasks, obligations, and rights distributed according to levels of seniority, which in turn also implies superordination/subordination. ${ }^{18}$

Another popular story refers to the origin of Sembiran's first human beings from monkeys. At the beginning, there was a female monkey who was pregnant. But before she was able to give birth she died. Out of her belly grew a large tree, a kastuban tree. According to the storytellers this tree stood near the site where Pura Dulu, the most ancient temple of Sembiran, is located. The tree had been standing there for centuries and allegedly died only some decades ago. The tree was huge with big leaves so that the monkeys liked to play in its shady branches even during

\footnotetext{
${ }^{15}$ In today's village association each office is hold by pairs of men, each belonging to a ritual moiety, a fact to which the story also alludes. These pairs are related to each other like an older and younger brother. In the Bale Agung, their meeting pavilion, they sit opposite each other and perform their tasks together.

16 There are the offices of the penyarikan (secretary) and the kelian desa that are unpaired. However, they have no distinct seat in the sitting order of the Bale Agung; Guermonprez has stated the special position of these offices in Julah too (1998:54).

${ }^{17}$ I was told that benges wood (also called banges), the metaphor used for the highest office, kubayan, may not be used for anything.

18 The whole krama desa has to be seen as subordinate to the gods and the deified ancestors whose will the humans try to carry out - for their own benefit (Guermonprez 1980).
} 
the midday heat. During the rainy season, the tree was often hit by lightning followed by the growling of the thunder. The god Guru predicted that the tree would soon produce (inedible) fruits out of which human beings would develop. The goddess Sang Hyang Licin (her manifestation is the Moon; she is the wife of Bhatara Guru) descended to the earth to guard the tree when she heard the prophecy. She appeared on the earth as Daha Tua, an elderly unmarried woman (in fact, an elderly virgin woman). Some time later the tree produced four fruits. Since Sang Hyang Licin was guarding the tree, the lightning did not dare to strike the fruits. When the fruits were ripe, they fell to the ground and finally two (in another version: four) human beings came out of them, one (two) male(s) and one (two) female(s). Sang Hyang Licin was looking after them, gave them the sap of banana trunks to drink and millet (godem) to eat ${ }^{19}$ until they were grown up. The two men then decided to descend to the coast where they founded Julah; the two young women remained on top of the hill (Sembiran).

One day the two women and the two men met by chance in the forest. They married; one woman moved to the place of her husband while the other women refused to do so; her husband therefore moved up to Sembiran. This founding couple of Sembiran were the progenitors of the Bali Mula, the aboriginal inhabitants of Sembiran. They are described as hairy human beings who followed agama sambu, the veneration of trees and stones. They are considered to be the ancestors of some few families who still live in the Banjar Desa of Sembiran. The office of the temple priest of Pura Dalem is hold by Bali Mula descendants. Sang Hyang Licin is venerated as daha tua in the Pura Dulu; the unmarried women (daba bunga, young unmarried women, and daba tua, elderly unmarried women) of Sembiran are united in a special women's association. In a ritual context these women are associated with the goddess. This women's association is ranked by seniority and has distinct offices held by older women (daha tua). ${ }^{20}$ The daha have their special meeting day (once a month) at a special pavilion in the village temple.

A similar history, the origin of the first humans from animals, is said to have taken place "later" than the first one. This story relates the origin of Sembiran's inhabitants to cocoons of cicada (bugading) that hung at the leaves of a starfruit tree (belimbing). Pura Belimbing is situated at the place where the original starfruit tree stood. The Pura Belimbing is located only about 30 metres east of Bale Bunder (see below), one of the oldest meeting places of Sembiran. There were also four human beings, two males and two females, who came out of the cocoons. While

\footnotetext{
${ }^{19}$ Millet is nowadays grown in small quantities and for ritual purposes only, where it is used in a couple of small (but important) rituals. I suggest that millet was once a major food crop, probably even before the advent of rice.

${ }^{20}$ Galungan und Kuningan, the New Year according to the Hindu-Javanese calendar, are the festivals in which these women play a crucial ritual role by commemorating Sang Hyang Licin as Daha Tua and the way she mothered the newly born babies and assisted them in becoming adults - the ancestors of Sembiran.
} 
one of the two males, Bagus, was a follower of agama Hindu (Hindu religion), the other, called Mpu Gandri, is said to have taught Islam; he finally emigrated to Java. The descendants of Bagus are those families who hold the office of priests for the Pura Dulu. I Bagus is considered to be the founding ancestor of Sembiran's Bali Aga by some people. Bali Aga are junior to the Bali Mula. The priests of Pura Dulu are said to be descendants of these Bali Aga.

All these histories (a further one deals with yellow coconuts out of which human beings developed) relate men and women, Sembiran's first inhabitants, to a non-human origin. These histories seem to emphasize the fact that these first human beings did not have relations to other groups of people located somewhere else; giving them an indirect claim to autochthony.

In contrast to these histories, there exist a number of other stories that tell how immigrants came to Sembiran. Liefrinck mentions a history according to which a couple suffered shipwreck and drifted on a plank to the shore of Sembiran. Sembir, meaning 'plank', led to the name of the village, Sembiran, thus commemorating its origin (1934:66). Since its integration as a desa dinas and a desa adat (nowadays called desa pakeraman) into the Indonesian state, Sembiran has created an emblem that displays a boat alluding to this event. The same story - with many variations - is still told today.

There exist at least as many versions of immigration histories as of creation histories.

For the story tellers (and the audience), there was no real difference between them with regard to truth; both types were true and questions of historical accuracy generally did not matter. Nevertheless, from a Western academic perspective the former histories tell quite a lot about the interactions of the villagers and the immigrants who seem to have come to Sembiran sometimes in smaller, sometimes in larger groups. Most of the interactions described are with immigrants who were adherents of agama slem (Islam religion). A single Moslem man who brought new weaving techniques (see Nabholz-Kartaschoff this volume) to Sembiran is portrayed as black dog that impregnated a young female weaver (the woman was the human daughter of a sow, the latter being a metaphor for the aboriginal inhabitants whose most important sacrificial animal is the pig) in Sembiran. This scandal, expressed in terms of bestiality almost led to the break-up of the village (see Hauser-Schäublin 2004c:12-13).

\section{The Introduction of New Beliefs, Practices and Institutions}

The most prominent history of Muslim immigrants deals with a larger group of people who arrived in the Sembiran/Pacung area probably sometime in the $17^{\text {th }}$ century. This group was led by two outstanding personalities. One is called Ratu Subandar, The Harbourmaster, and also Ratu Pesisi, The Master of the Shore. The 
second is called Ratu Kamasan (a name I am unable to explain). ${ }^{21}$ Both came from Java and were disciples of agama slem (a specific form of Islam religion); they went ashore at the site where today Pura Sang Hyang Marek ("The Venerated" or "Holy Arrival") is located. Ratu Subandar and Ratu Kamasan then proceeded further eastwards but were apparently not welcomed in the village there, in Sembirenteng (where there was another important harbour, today's Pura Pekonjongan). As a consequence, they returned to the first site where today Pura Sang Hyang Marek stands.

As the oral histories tell, these immigrants were apparently on colonizing missions, though they were not always successful. Ratu Pesisi and Ratu Kamasan climbed up the hill on which Sembiran is located. Near Pura Dulu they rested. Ratu Kamasan then turned west; he left the village and proceeded to an isolated place above a huge ravine (Yeh Lengis), where he settled. Today this site is commemorated by a temple called Pura Melaka; the name allegedly came from the melaka trees growing there. Halfway between the core village and Pura Melaka lies a further temple, called Pura Sanda, the residence of Ratu Pesisir's first wife. ${ }^{22}$ After a while, Ratu Kamasan considered his place too far off from the village. He therefore moved back and settled near a place called Pendem ("grave"). Today a tiny temple commemorates this site, too. ${ }^{23}$

In Sembiran, both Ratu Pesisi and Ratu Kamasan are associated with distinct offices. Ratu Pesisi is described as a prebekel (or mekel, 'village head') and Ratu Kamasan as a klian adat (ritual leader), implying that the former was concerned mostly with the social order. Ratu Kamasan is described as a religious innovator who introduced new ritual practices and reformed old ones. Some versions maintain that Ratu Pesisi's domain reached from Pura Polaki (far west of Singaraja) to Pura Pekonjongan (Sembirenteng). Others are less clear about its boundary in the west but confirm that it was Sembirenteng in the east. Ratu Pesisi is said to have restructured the whole village and its organization. Ratu Bolot, another companion, was said to be the penyarikan of Ratu Pesisi that is the assistant (often translated as "secretary"), or the body guard.

All these oral histories (or fragments of them) recall the deeds of these immigrants as engendering cultural transformations from the perspective of the successful reformers.

\footnotetext{
${ }^{21}$ For an extensive version and interpretation of this history see Hauser-Schäublin 2004b.

${ }^{22}$ Ratu Pesisi later took a wife, who came from the nearby village of Satra up in the mountains. Her place of residence is said to be commemorated by a tree at Pura Sang Hyang Marek. The klian adat of Satra told me in the late 1990s that villagers from Satra formerly visited the temple Sang Hyang Marek.

${ }^{23}$ Sutaba mentions seeing this temple in 1971. It then consisted of just a pile of river stones, irregularly arranged (Sutaba 1985:10). Today this shrine or tiny temple is made of concrete.
} 


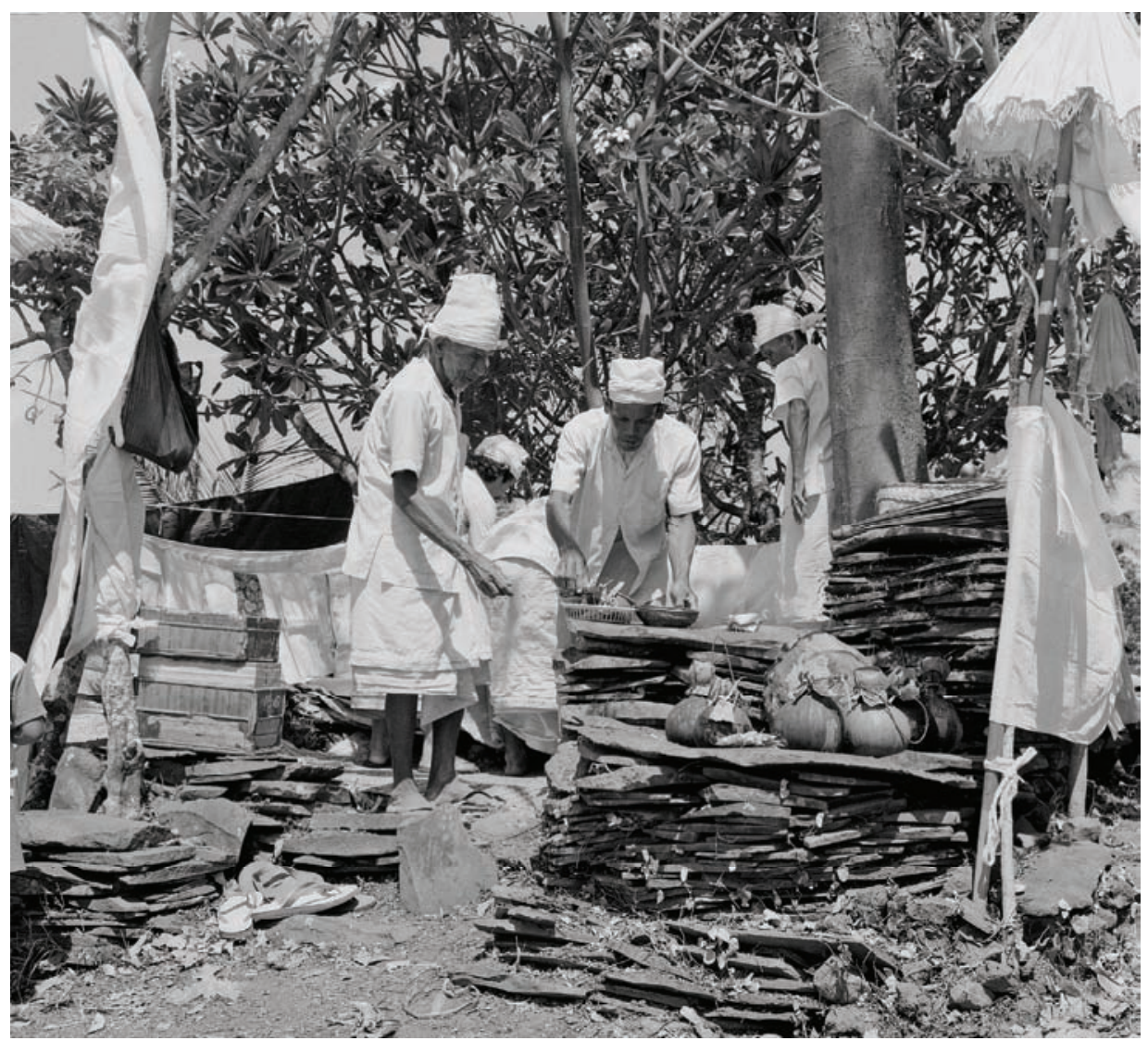

Photo 6: Pura Melaka in Sembiran is one of the last temples that has not yet undergone thorough renovation and rebuilding. The shrines still consist of heaped stones. The shrines are decorated for the annual festival. Photo: Jörg Hauser 1997.

Some versions of these stories have it that Ratu Pesisi and Ratu Kamasan met the original beings in Sembiran in the form of cocoons (bugading; see above) hanging from a star fruit tree (belimbing), that is, not yet fully developed or mature beings let alone human beings. Told in the context of immigrant reformers, this trope suggests a rupture in tradition, fledglings that were waiting to be transformed into full human beings by these immigrants. ${ }^{24}$ This could relate to the task of Ratu Kamasan, who introduced new ritual practices in sharp contrast to the pre-existing

${ }^{24}$ As the genetic research carried out by the Swiss physician and anthropologist Georges Breguet has shown, out of the villages throughout Bali he investigated, only three - Julah, Pacung, and Sembiran - displayed particularities that otherwise were unique to the populations of Yogyakarta, Makassar, the Bugis, and Bima (see Couteau 1999:186). Thus these genetic results seem to confirm the important influence the immigrants had on Sembiran's population. 
ones. As a result, his innovations split people into two different groups with ritual practices of their own: Islamic rituals without pork and "Hindu" rituals in which pork is crucial. Conflict arose over the issue of the appropriate sacrifices to be offered to the gods. Finally the conflict was solved by creating a kind of syncretism in line with Sembiran's ritual practices of today (see Hauser-Schäublin 2004b and 2007).

It is this history that has left strong imprints on Sembiran's ritual life, though today it is not clear which family is a descendant of these influential Moslem immigrants. There are no inhabitants that call themselves "Hindu" in contrast to "Moslems" or vice versa. It depends on individual preference, i.e. who enjoys eating pork and who does not, and is no longer a dogmatic question.

The analysis of Sembiran ritual practices shows that the major issues of the oral history connected to Ratu Subandar and Ratu Kamasan are taken up in rituals as well. According to the compromise that the Muslim immigrants and the autochthonous population reached, for each ritual today there are offerings prepared without pork (baktian slem) dedicated to Islamic ancestors, and offerings with pork (baktian bauwi) for the Hindu-Balinese ancestors. The preferred animal sacrifice of the Moslem immigrants was the calf (godel), an animal rarely eaten by those who maintain they are not descendents of these immigrants but aboriginal inhabitants. Moreover, those who have eaten beef have to undergo purification before they enter a temple (Hauser-Schäublin 2007).

Ratu Pesisir/Subandar and Ratu Kamasan as deified ancestors have also left their marks on the spatial organization of the village, mainly with regard to its temples. Both have their seat, as briefly mentioned, in Pura Sang Hyang Marek. However, there is a huge ritual cycle in the fifth Balinese month that is performed in commemoration of (and probably initiated by) these immigrants from Java. Through this ritual cycle, which lasts for about two weeks, a territorial and social integration takes place. The whole krama desa, the members of the village assembly, participates. The ritual starts in the Pura Desa, the central village temple where both Ratu Pesisi and Ratu Kamasan (and, additionally, a further partner of Ratu Pesisi, Ratu Bagus Pura Agung) have a shrine in the village temple (see below). On a subsequent day, the ritual cycle moves to Pura Tegal Angin, located at the south-eastern border of the village. The Tegal Angin temple is considered to be a guardian temple that protects the village from raids from the mountain direction. For the geographical location of Sembiran's temples see Figure 3. 


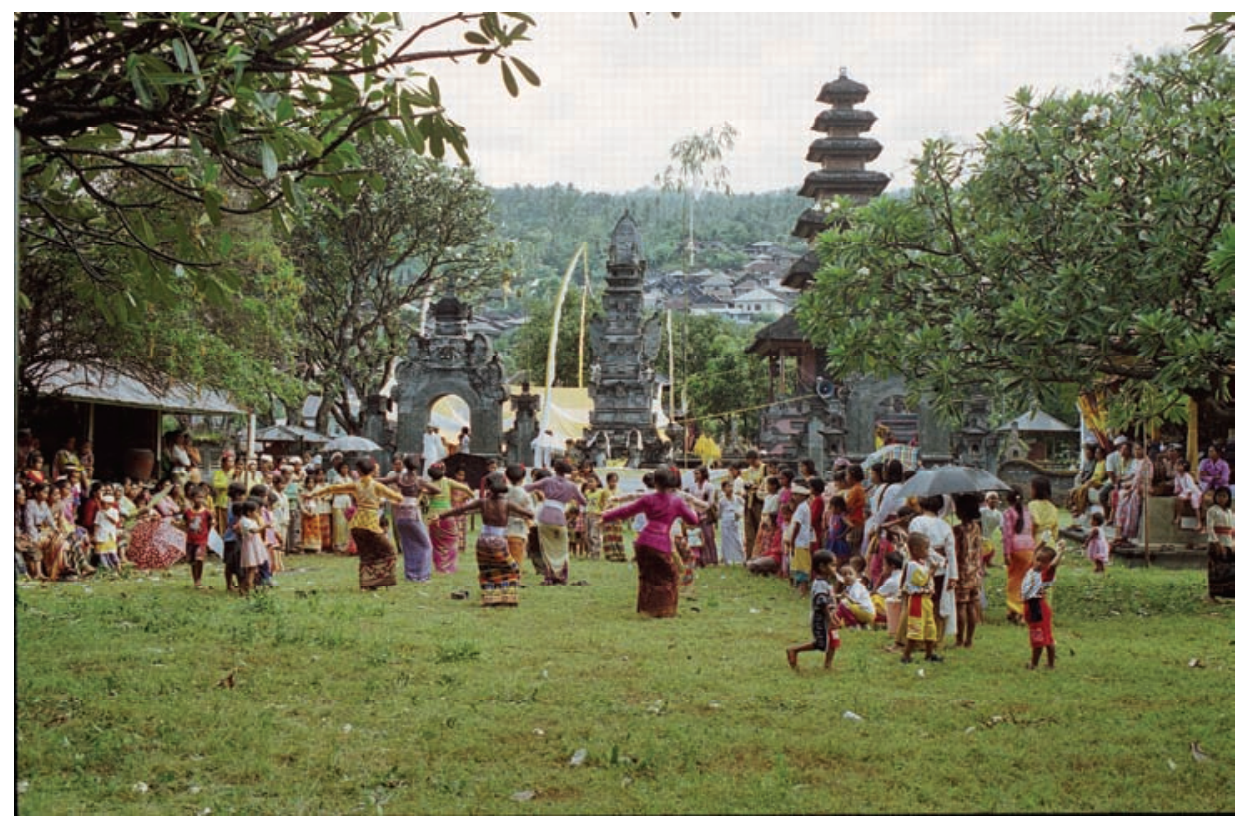

Photo 7: A major ritual in the village temple of Sembiran is concluded by a rejang dance performed by the female members of the krama desa, pelukayu.

Photo: Brigitta Hauser-Schäublin 2001.

On the third day, the ritual reaches its first climax in the Pura Sang Hyang Marek. The members of the female association of the krama desa (that is spouses of the male members of the krama desa) start making offerings, some of them of outstanding size; these are made in the name of boy priests dressed in white (mangku bunga) who are the sacred followers of Ratu Bagus Pura Agung. ${ }^{25}$

Ratu Bagus Pura Agung is associated with trading relations with the Batur area in the mountains, where there probably had been a royal court and one of the most important trans-island markets, as well as a state temple responsible for collecting tributes (see below). Some oral histories suggest that Ratu Bagus Pura Agung, to whom one of the most honourable shrines in the Pura Sang Hyang Marek is dedicated, even originated from Batur; he seemed to be responsible for the relations between the port and the dominant inland polity and correspondingly for the safe transportation of the trading goods.

${ }^{25}$ The mangku bunga participate in another ritual cycle as well that focuses on the relationship with temples in the Batur region. Boys between five and twelve years of age are appointed by the gods, often through illness or dreams. 


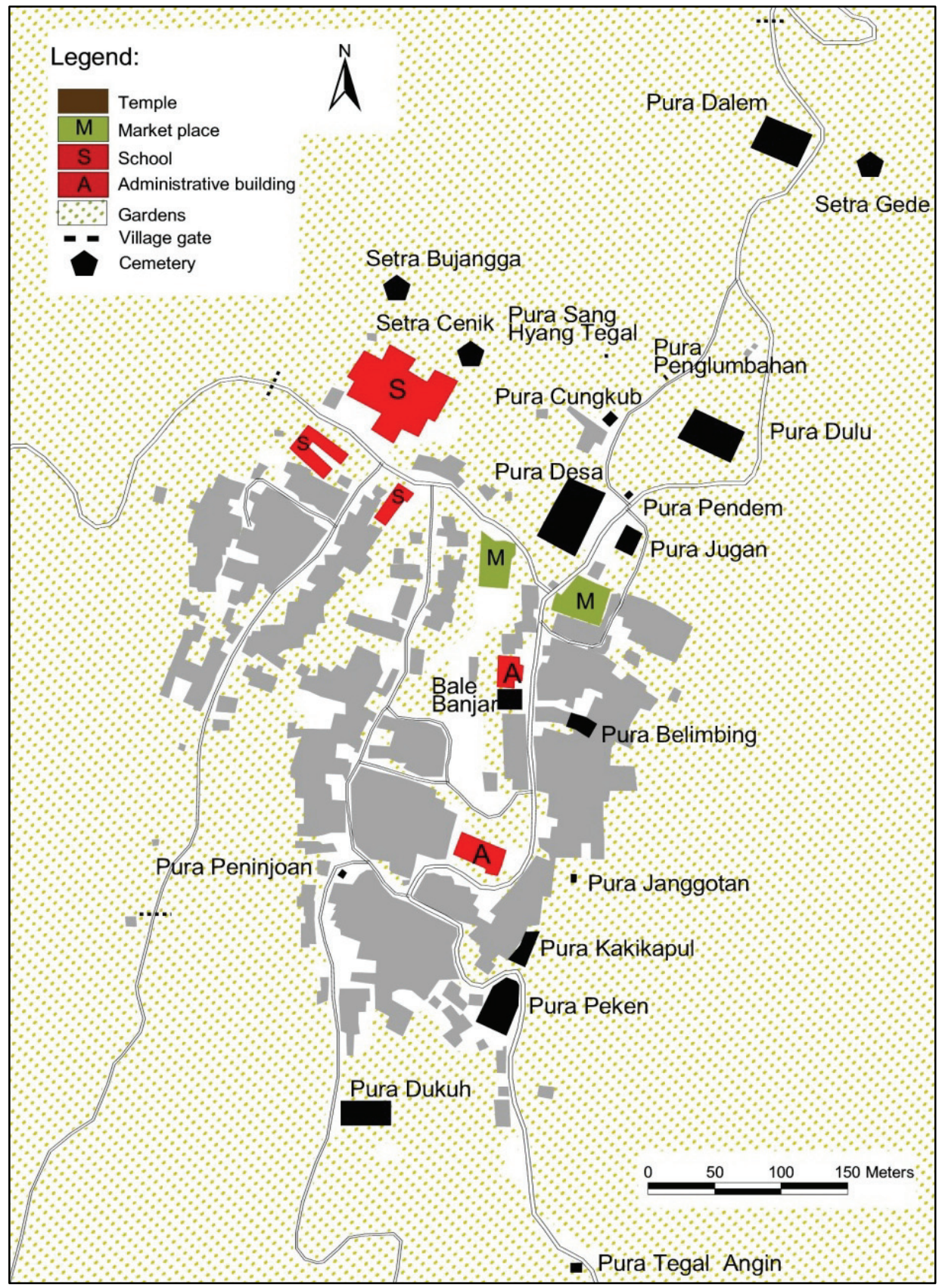

Figure 3: The layout of Sembiran village with its main temples in 2005. Cartography: Enrico Kalb; source: Quick Bird Satellite Image 2003. 


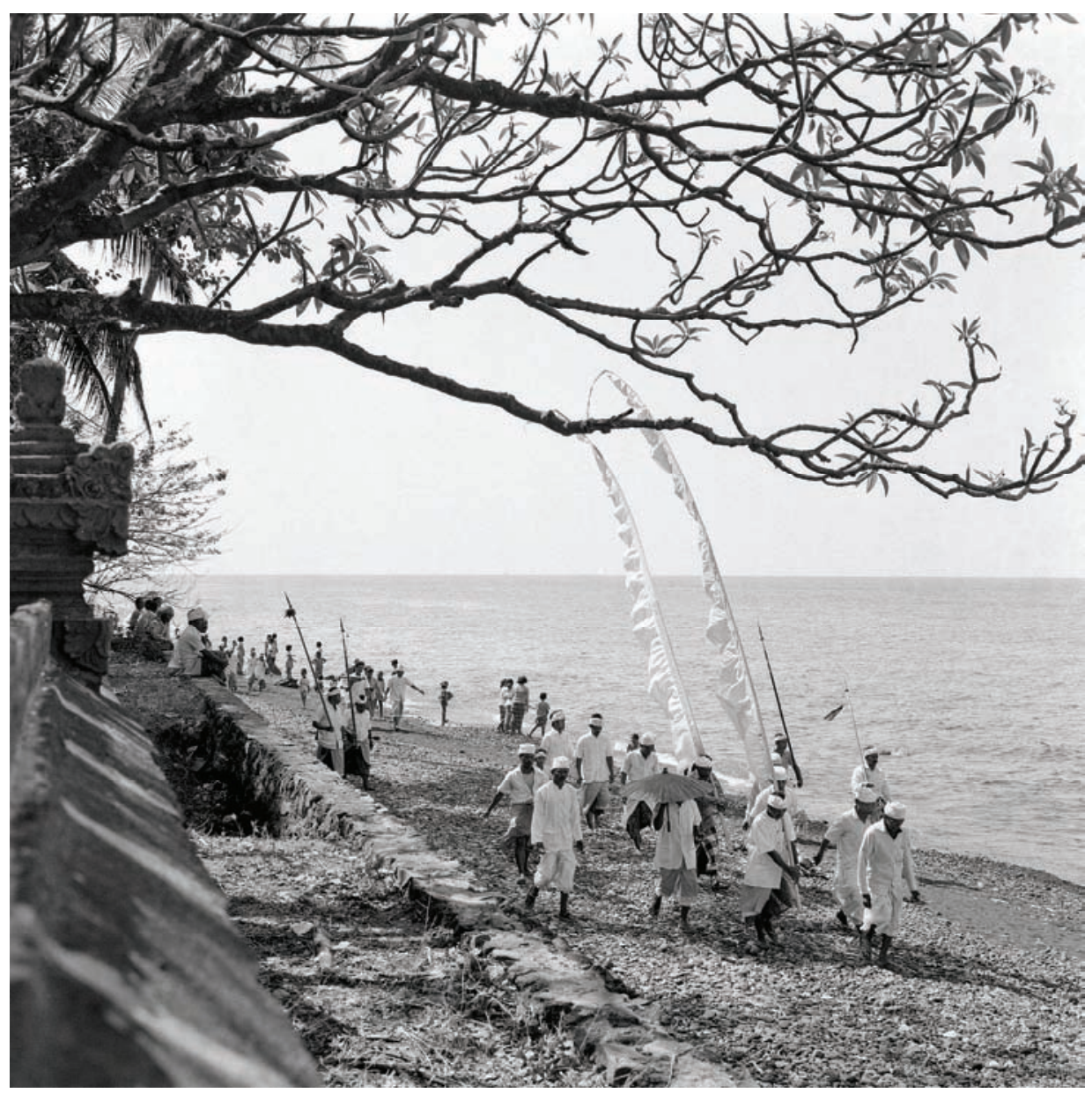

Photo 8: Ritual elders escort the deity Ratu Gede Sakti to the temple of Sang Hyang Marek located on the edge of the sea.

Photo: Jörg Hauser 1997.

At noon a group of priests and the most senior members (paulun desa) of the krama desa go to meet the deity Ratu Gede Sakti, a further companion of Ratu Pesisir and Ratu Kamasan at his shrine (directly on the shore) at some distance west of Pura Sang Hyang Marek and invite him to participate in the ritual. Some time in the afternoon, a group of priests and the ritual leaders follow a small track to a crossroads, where they invite Ratu Pesisi's wife from Pura Sanda to participate as an honoured guest in the ritual as well. Only when all are assembled the ceremonial dances (baris, legong, and rejang) are performed.

On the next day, after a visit to the regional temple of Ponjok Batu, the ritual community walks up the Sembiran hill on the old track accompanied by the gong 
orchestra, passes Pura Sanda, and proceeds to Pura Melaka to celebrate Ratu Kamasan. On the following day, the ritual continues in the Pura Empu, a small temple in a cave where a hermit (of Bujangga denomination) apparently once lived. On the following day, the cycle reaches Pura Pintu, the temple of a former autonomous settlement that no longer exists. The whole cycle ends in a small temple in Sembiran. Thus, this ritual cycle in which new offerings and new ceremonial meals are continuously prepared and consumed and in which all the dance groups perform, unites all these personalities and their sites. It is probably the most sumptuous ritual cycle of Sembiran and not only keeps the whole village continuously busy for many days but heavily draws on people's resources, too.

These histories of the Moslem immigrants certainly carry some grains of knowledge about a former transmaritime harbor and its relationship to the inland. These histories therefore seem to confirm some of the historical descriptions from the $10^{\text {th }}$ to the $12^{\text {th }}$ century (copperplate inscriptions) as well as the archaeological data that prove contacts with India even at a much earlier age. However, the oral traditions about Ratu Pesisir/Subandar and Ratu Kamasan deal with a much later time. The deified subandar venerated in Pura Sang Hyang Marek was the subandar of the harbour that once existed on the same site as today's temple. As is well known, Islam came to insular Southeast Asia through merchants and thus followed the major trading routes. The connection between the "market place" and a sanctuary dedicated to deified arrivals seem to support the thesis of a harbour there.

In fact, such transmaritime harbours important to the economies of the complex polities that needed such ports and their goods were directed by a harbour master, subandar. As far as we know, such harbour masters were appointed by the king (Wardka 1987). A subandar was in control of the ships, their loads, and the taxes the captains and merchants had to deliver. This office and the person who held it were crucial for the working of trade and trans-island trade relations.

The report of a Chinese merchant who came on a Thai ship to Buleleng in the first half of the $19^{\text {th }}$ century allows a glimpse into the operation and function of the harbour, the office of the harbour master, the market place associated with it and the relationship with the royal court on whose behalf the harbour acted in pre-colonial Bali (Graves and Kaset-siri 1969).

\section{The Village Structure and its Major Temples}

In this chapter I shall apply a different perspective, one that is based on my own empirical investigations into the social, political and religious organization of Sembiran.

Today, Sembiran's territory spreads over a vast area and consists of 10 banjar or neighbourhoods; it amounts to 1.792 hectares. As you can see in Figure 2, 
Sembiran consists of a core village and two banjar dinas (Bukit Seni, Panggung) that are located high up in the mountains, settlements of immigrants who arrived over the past 60 to 100 years.

In former times, most of the especially fertile land was communally owned village land (Liefrinck 1924). The final dissolution of communal land and its regular redistribution took place in the context of the Indonesian land reform in the 1960s; as early as the 1950s a large quantity of desa-owned land (675 hectares) was divided amongst 166 members of the krama desa (Lansing 1977:196); the only remnant of communal land, it seems to me, is that belonging to the Sekehe Gede ('The Big Association'), an organization in which all core clans (dadya) are represented (see below). The official list kept in the office of the kepala desa, the administrative village head, shows that several organizations/institutions have special land rights (usufruct): $185.305 \mathrm{~m}^{2}$ is temple land, $10.600 \mathrm{~m}^{2}$ belong to the baris dance group, $10.000 \mathrm{~m}^{2}$ to the Sekehe Gede and the two types of gong orchestras (gamel and angklung) hold $2.550 \mathrm{~m}^{2}$ and $3.700 \mathrm{~m}^{2}$ respectively. The settlement area (tanah pekarangan) contains $100.000 \mathrm{~m}^{2}$ and the three graveyards $20.000 \mathrm{~m}^{2}$. The only individual who today still receives village land $\left(3.500 \mathrm{~m}^{2}\right)$ for his personal use is the Mangku Gede, the (former) leader of all temple priests (Awig-Awig Desa Adat Sembiran 1988: paragraph 1, 24, 44); this seems to be the only survival of the former land right described by Liefrinck: Apart from the forests (alas wayah), the settlement ground (tanah pekarangan), and individually owned land (tanah palak) most of the best agricultural land (along the coast) was owned by the village (tanah pedesaan) and regularly redistributed among the members of the krama desa (Liefrinck 1924:381-384); the redistribution took place every ten years. ${ }^{26}$ Important office holders in the village organization received a special share of the communal land.

The village was formerly fortified, as the earliest as well as later inscriptions testify for Julah; apparently the core-villagers lived here. There are still five gates (kuta) located at paths (today most of them streets) leading in different directions to and from Sembiran. Formerly there used to be a belt of forest (padang wayah) supplemented by thorny plants that enclosed the village like a fence; the gates were the only entrances to the village. Today these gates are still annually reconstructed with light bamboo tubes; they have a predominantly symbolic function (to ward off all evil). Sembiran is also surrounded by temples some of which are situated quite far off from the settlement. There are two temples (still in their original shape in 2006), Pura Suksuk and Pura Ngudu, located at the foot of the hill on which Sembiran is situated. They served as kinds of guardian temples against penetrators from the main path leading along the north coast and directly

\footnotetext{
${ }^{26}$ Liefrinck mentions that land (tanab tetaminyan desa) was given for permanent use to peasants from Pacung and Bondalem under the condition that they should not sell the land to other people than those from Sembiran. At that time, the district head was living in Bondalem (Liefrinck 1924:383).
} 
from the sea. There is a similar guardian-temple located on the path that formerly led to the mountains, Pura Tegal Angin (see above).

Twenty-three clans (dadya) socially constitute the core village; each dadya has its own clan temple (see also Bagus 1968). Only members of these clans can become members of the ritual village association, krama desa, and are obliged to partake in ritual life with all the rights and duties this implies: to have access to village land (for example to build a house on tanah pekarangan), to perform work and tasks for the krama desa and to deliver the contributions in money and kind requested. ${ }^{27}$ Dadya are patrilineal in principle though linearity is difficult to trace and it is impossible to establish genealogies.

An individual is only rarely able to name his lineal predecessors further back than two preceding generations (parents and grandparents). To be able to remember of these three ascending generations is important to establish land claims and the right of building/inhabiting a house within the village. ${ }^{28} \mathrm{It}$ is within this frame of reference that rules of marriage - exclusively negative ones - are defined: apart from marriage between siblings (by blood as well as classificatory, half-siblings), a man is not allowed to marry his niece (by blood or classificatory) ${ }^{29}$, any sister (by blood or classificatory) of his father, the sister of one's sibling spouse or any sister-in-law. However, since every person is embedded in criss-cross relationships, a man may describe another person in different kinship terms depending on whether he considers the line of his father or of his mother. ${ }^{30}$ Violation of these rules of exogamy (with regard to the patrilinear clan) has consequences ranging from the performance of purification rituals of the couple to dismissal from the krama desa (Awig-Awig 1988: paragraph 60). Further, marriage is forbidden between members of the Bujangga Clan and the Bali Mula (no explanation for this rule). Membership in a dadya, apart from the nuclear family, is often expressed through living at a distinct place within the village (tanah pekarangan). If a couple have no children, all their possession is taken over by the village. ${ }^{31}$

There are many mechanisms that de-emphasize linearity: First, teknonomy (the fact, that for example, a man is called "father of XY"), second, birth order names

27 The term krama (kraman) as an expression for core villagers is already mentioned in the earliest inscription (104 Sembiran A I, saka 844). The term desa is first mentioned in the Jayapangus edict (no 621, Sembiran C, Ardika 1991:259), dated saka 1103. In the 409 Sembiran A IV inscription (saka 987) the term thani (complemented by watek) seems to have replaced the earliest term, banua. According to Christie (based on material from Java) this change of term reflects the reorganization of administrative units (see Christie 1994).

${ }^{28} \mathrm{It}$ is the youngest son of a man who is entitled to inherit tanah pekarangan.

${ }^{29}$ Liefrinck notes that in other parts of Buleleng a marriage between nephew and niece is allowed (1934:330).

30 One of my best informants, for example, could call the brother of his wife also "younger brother". It is probably due to this complicated set of relationships that there existed an enduring conflict over land between them.

31 A similar regulation is already mentioned in the 104 Sembiran A I inscription (saka 844). 
(which seem to be more or less a recent adaptation to what is considered panBalinese adat), third the fact that a couple choose and adopt a new name (one and the same for both spouses, the difference being only the gender markers) after marriage ${ }^{32}$ when they are granted access as full members to the krama desa. The krama desa is divided in the organization of the male members and those of the female members (the wives of the male members), called pelukayau. A couple stays in this organization as long as the marriage exists; when one of the spouses dies, the other has to leave this organization and becomes a member of the krama desa sampingan, also called paki palu (paki - 'children already married', paku 'widow/er'). This pensioners' organization also includes those whose children are all married or who already have great-grandchildren. Moreover, immigrants can become member of this organization too. They are all invited to participate in all rituals but do not have any active function.

The offices in the krama desa are organized according to the principle of seniority (duration of the marriage), the members being arranged in two rows, one associated with 'elder brother' (wayahan) and the other with 'younger brother' (nyomanan) or 'west' and 'east' (sometimes also 'left' and 'right'). When one of the ritual elders dies, the other, junior, members move upwards (in a mountainward direction) physically in the sitting order in their meeting pavilion (bale agung), socially in the organization as such. The movements do not follow each row separately but in a zigzag order, with the consequence that the individual members of krama desa are at one time in the 'younger' and at another in the 'older' line. Thus with each ascent the individual changes his moiety membership. ${ }^{33}$ There are several hundreds of men who are members of the krama desa today. But there are only a couple of offices held by the most senior men that are considered the most important. These paired offices are from the top downwards: 2 kubayan (this office has been void for half a century, allegedly due to the high costs the accession requires) ${ }^{34}, 2$ siut, 2 bau, 2 singgukan, (2 bahan tandluk, 2 bahan kelakah), 2 bahan temuangan (they are assisted by 30 bahan cacar), 2 pengulu (sedahan agung, this office exists no longer), jabya (no definite number), 18 or 20 panakawan, 2 pemubit; the newly married start as pemubit, novices. The leaders of the krama desa are called paulun desa and consist of 12 people (from kubayan, siut, bau, singgukan, bahan temuangan to pengulu); they are

\footnotetext{
32 Barth thinks that spouse unity is less important in Sembian than in Julah (1993:83); I would not however agree with this.

${ }^{33}$ In Julah the ascent in the krama desa takes place within each row, thus the division into two distinct ritual moieties is much more emphasized than in Sembiran (see Guermonprez 1998:54-57). For comparative research and analysis of the social organization of villages, mostly located in the central mountain range, see Reuter 2002b.

34 The office of kubayan (or kabayan) is first mentioned in the 409 Sembiran A IV inscription, dated saka 987. Apparently, this office was then already tied to a village association since the office holder is referred to as rama kabayan. In the Japapangus edict (saka 1103; no 621 Sembiran C), a "kabayan gosti" is mentioned who apparently held this office on the basis of (noble) descent.
} 
complemented by the temple priests (pamangku and the kelian desa). The actual leaders today are the jero siut. The kelian desa is elected at a meeting by the krama desa. He remains in office for five years (a second period is possible); he and his assistants such as the penyarikan, the 'secretary', are counted as prajuru desa; their function is to witness on behalf of the people all rituals in the temples. By contrast, the temple priests are oriented towards the gods only (Awig-Awig Sembiran 1988: paragraph 13, 14).

While the krama desa is primarily an organization of married couples (with parallel associations for unmarried women and men), there exists a further organization, sekehe gede, in which all (autochthonous) clans are represented. In sum, the core village bundles all individuals and gives each a specific place in relation to all other individuals - and the place of all individuals together in relation to the gods since the major goal of this organization consists in venerating the gods, maintaining their sacred sites (temples), and in performing rituals for them. The sekehe gede is an organization that bundles all clans together and gives each of them an equal voice.

Today, everyday life is no longer determined by these institutions. There are other necessities and orientations that have become more important - education (and the necessity to find enough money to allow children to go to school), to make a living in an area with only little developing potential, to provide the family with sufficient daily food and water, health concerns - and many others. Moreover, there are new administrative structures, those of the Indonesian state, which regulate all aspects of life of the villagers beyond religion. Nowadays it is only a small percentage of the krama desa members, both males and female, who participate in the temple rituals. There are voices claiming that the money spent on elaborate rituals should better be spent on other things that promote the standard of living. In contrast to these public rituals, the life cycle rituals carried out individually still flourish, perhaps even more than before, and emigrants often return for such rituals. ${ }^{35}$

\footnotetext{
35 The names of these life cycle rituals have recently changed. The original Sembiran terms have been replaced by those common in many South Balinese villages. The ritual for a pregnant woman was formerly called magedong-gedongan, the ritual for a newly born baby medapetan; the ritual for the umbilical cord falling off kepus wodel (pan-Balinese: mesakapan), the 42-days-ritual: tugtug kambuban; the monthly ritual (every 35 daxs): metebus bulanan; the six months' ritual: motonan; the ritual called in South Bali ngotonin: ngeraja singa/ngeraja sewala; the teeth filing ritual: metatah, and the marriage ritual: pawiwahan. After marriage a couple has to perform the following rituals; beakawon, penyari, kelaci, ngerebu, melis, kamaligi, metebus menek, ngaturin; see also Riemenschneider and Hauser-Schäublin 2006.
} 


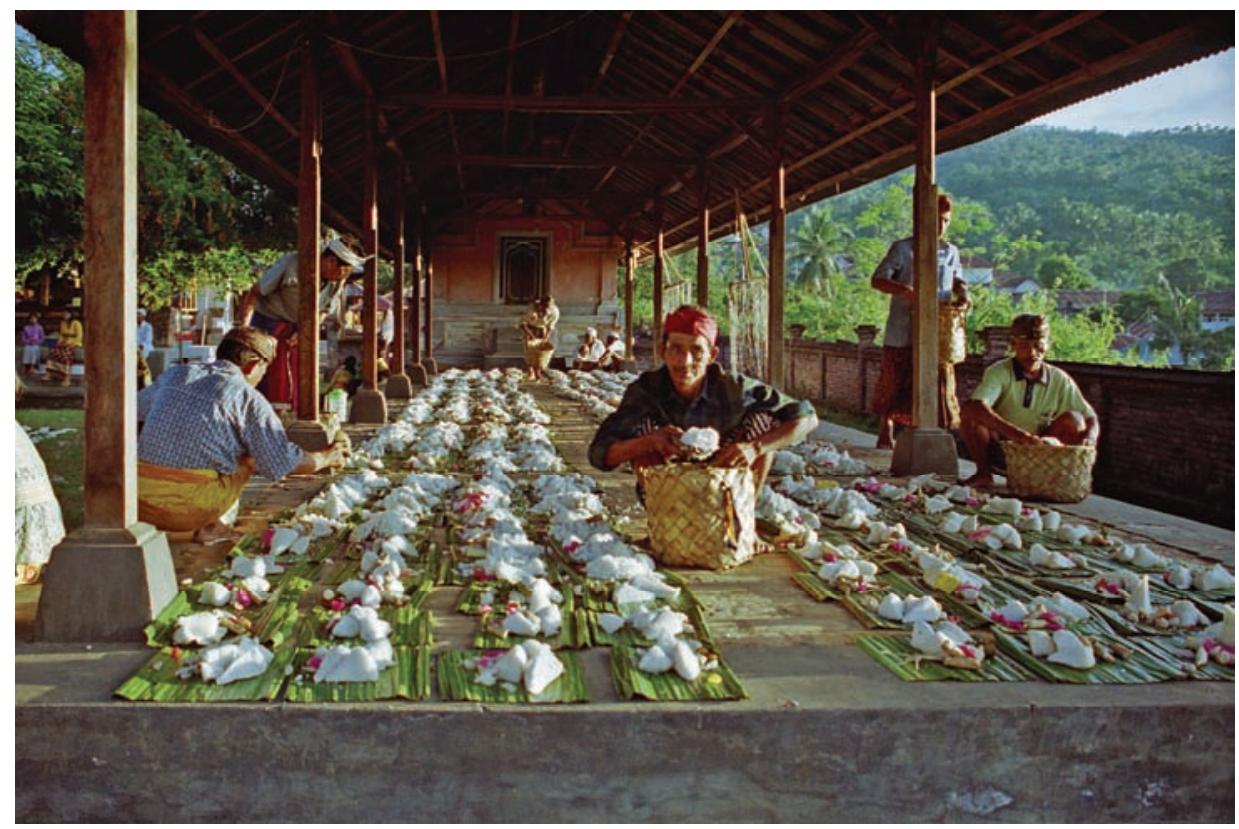

Photo 10: Each temple ritual is concluded by members of the krama desa dismantling the offerings for the gods and reassembling them into a ritual meal for the male members of the krama desa. The food portions (kawosan) are laid out in the Bale Agung according to the sitting order of the krama desa with the ritual leaders at the top.

Photo: Brigitta Hauser-Schäublin 2001.

The oldest banjar is the Banjar Desa, located in the north-eastern edge of the village. It seems that this was once the original village that stretched in two sections along a main path; one of these sections was banjar kangin (the eastern neighbourhood) and the other banjar kawanan (the western neighbourhood) according to their location. ${ }^{36}$ It is the place where, according to oral histories, the very small number of aboriginal inhabitants of Sembiran, called Bali Mula, still live. All other inhabitants of Sembiran are later immigrants who came at different epochs to the village (see above, Histories of Origin). In Julah, informants maintained that all aboriginal inhabitants died out a long time ago; all of the present inhabitants are immigrants who arrived at different points in time. Nevertheless, the krama desa tegak, the assembly of the core villagers, consists of members of those families considered to be the genuine people of Julah. Immigrants who came over the past 100 years or so have a different, more passive status than the core villagers and are

\footnotetext{
36 In some oral traditions two further banjar are mentioned, banjar kangin and banjar kelod, suggesting that Sembiran once consisted of a fourfold division. I have no further indication on this. The earliest evidence for the term banjar is found in the no. 409 Sembiran inscription dated saka 987, in which the head of the banjar is mentioned.
} 
clearly dependent on the latter. A similar, though less strict and clear-cut relationship exists in Sembiran between core villagers and recent immigrants.

Oral traditions hold that Sembiran's first settlement was somewhere else, west of Pura Dulu, which is today only agricultural land. From Pura Desa the village has expanded to the west and up the hill (that is, to the south). Today's most western banjar, Banjar Bujangga, is inhabited mostly by the survivors of a former village, Pintu, about 3 kilometres west of Sembiran. The substantial extension of Sembiran's territory to the west is the outcome of these events since the refugees of Pintu (all of Bujangga descent) ceded their original land to Sembiran in exchange for being accepted as full members by their host village. Pintu was, I think, the last settlement in this area that was plundered and destroyed by pirates, probably in the late $18^{\text {th }}$ century. Another reason for the western extension of the territory may be the consequence of the battles with intruders from Lombok and later, in the $19^{\text {th }}$ century, wars between Buleleng and Bangli, when the village Bayad was destroyed (see Liefrinck 1934:65; Hauser-Schäublin 2004b:330).

The cornerstones of the village are the major temples (pura). ${ }^{37}$ The ritual specialists, the temple priests (mangku) and the ritual elders of the ritual village organization (krama desa) speak of "catur kabyangan", the four major temples, instead of three (kabyangan tiga), the precondition for a real desa adat suggested by reformist Hindu-Bali organizations today. These four major temples are: Pura Dulu, Pura Desa, Pura Puseh, and Pura Dalem. Pura Dulu is located on the top of a hill. Judging from the way this temple is used in rituals, as well as according to oral histories, this is the oldest of all temples. However, the archaeological survey that Ardi$\mathrm{ka}$ and his team carried out in the area of this temple (three pits were opened) in 2005, did not produce any material evidence. ${ }^{38}$ Pura Dulu is the temple of origin of the village in a much more comprehensive way than Pura Puseh, a temple clearly built during a later period. In Julah we were told that in former times the inhabitants of Julah also joined the annual festival at Pura Dulu in commemoration of the common origin and even brought their gong orchestra along to please the deities with their music.

\footnotetext{
${ }^{37}$ All the $10^{\text {th }}-12^{\text {th }}$ century inscriptions give evidence of the fact that a wide variety of religious specialists and dignitaries, temples, monasteries and rituals constituted major institutions in the organization of the king's (ratu, datu, aji, raja) realm.

${ }^{38}$ We were not allowed to open a pit in the precincts of the temple since this area is sacred.
} 


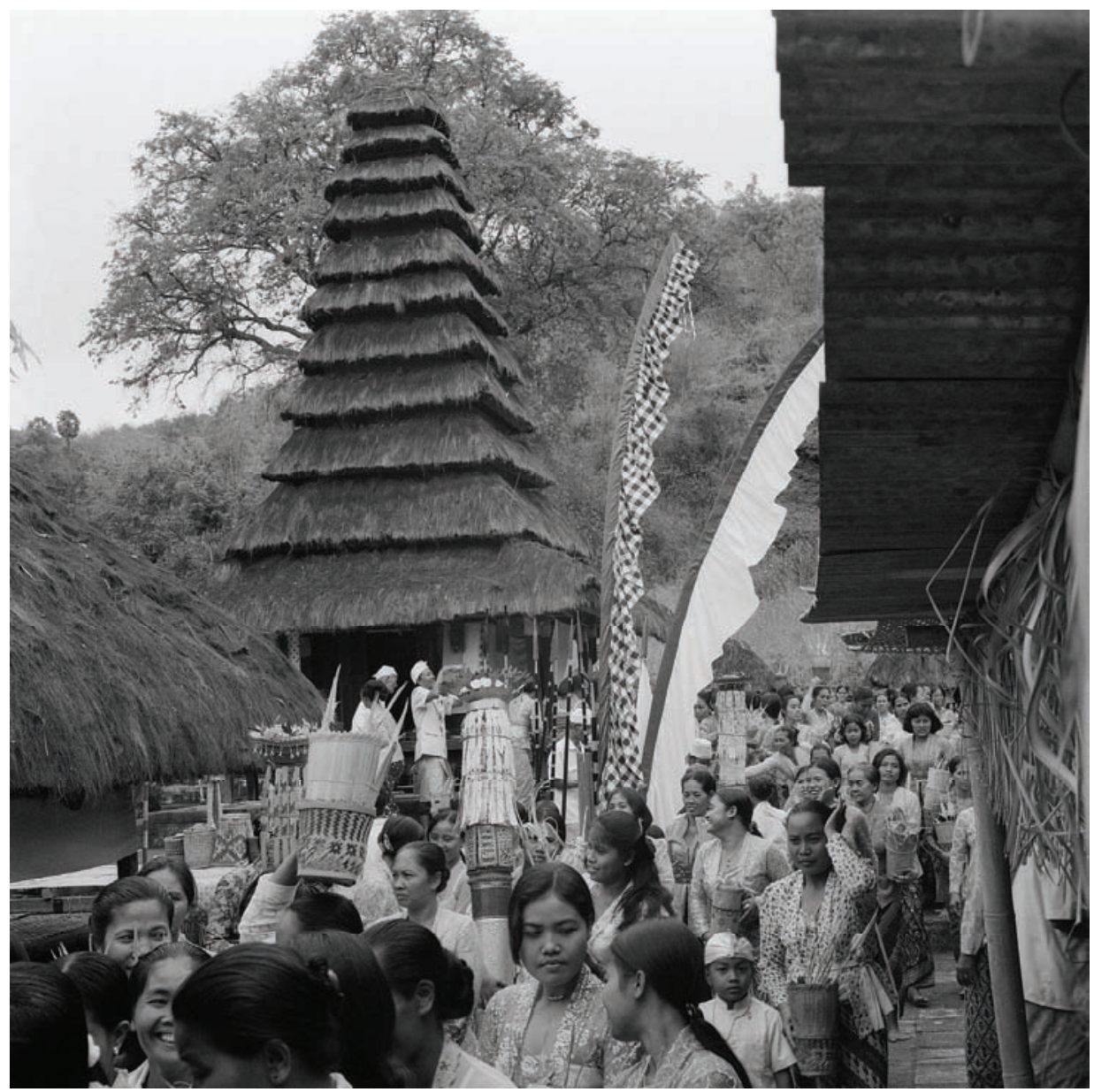

Photo 11: The village temple in Julah. Women returning home after having delivered offerings.

Photo: Jörg Hauser 2003.

It seemed to be a characteristic of Sembiran that many of its temples contained big stones, terraces and stone step pyramids; formerly, they were not surrounded by any stone wall but only by a light bamboo fence. With only two or three original temples left, all main temples have undergone complete renovation since the 1960s, when the village became wealthy from its cash crops (tangerines). For these renovations artisans and stonecarvers from South Bali were hired (Lansing 1977:200-202). These renovations completely changed the structure and the out- 
look (but not their orientation) ${ }^{39}$; the former menhirs were put on top of concrete shrines. ${ }^{40}$

Pura Puseh and Pura Desa are located on a single site and today fenced off by a common stone wall (see Figure 4).

The core of Pura Desa is a small section adjacent to the mountainward side of the Bale Agung (no. 36), the big assembly hall where the male members of the krama desa held their meetings. There are several small shrines which all refer to clans and/or other temples within Sembiran territory. This part of the Pura Desa embraces more or less all social groupings and represents a kind of central assembly courtyard of the village as a territorial and social unit. In the most prestigious and pure site, the mountainward eastern corner section of this part of Pura Desa, a three-tiered shrine for Ratu Pasek is located. This is a shrine (no. 21) associated with the clan of the Mangku Gede or 'Big Mangku', formerly the most important temple priest. His family is said to have originated from outside of Sembiran and was sent to this village apparently as a representative of the Batur temple.

This shrine and its sacralia are intimately connected with the Batur Temple (Pura Ulun Danu Batur), today located on the rim of the caldera of the huge Batur volcano in the central mountain range. As I have described in detail in earlier publications, this major temple was also a tax-collecting institution (HauserSchäublin 2005, 2007).

There are three further shrines (nos. 22, 25, 26) besides the shrine for Ratu Pasek dedicated to deified ancestors whose 'home' is in the temple of Sang Hyang Marek on the border of the sea; one of them (Ratu Bagus Agung), just adjacent to Ratu Pasek, is a representative of former trade relations to Batur. The other two are Islamic immigrants who acted as cultural heroes in Sembiran (see above). The shrine for Ratu Kumpi, in the third position, symbolizes the ancestors of the Bali Mula, the original inhabitants. ${ }^{41}$ Next to Ratu Kumpi is Ratu Didukuh, a representation of Pura Dukuh, the temple high above the village. Pura Dukuh is associated with the clan of the Bujangga, formerly a distinct ritual denomination. ${ }^{42}$

\footnotetext{
${ }^{39}$ Sutaba points out that in 1971 and 197217 out of 20 temples displayed a "megalithic character" (1985:3; cf. his description of Pura Dulu called Sanghyang Kedulu. 40 Pura Desa was renovated in 1961-1964, Pura Dulu in 1968-1971, Pura Dalem 19741976, Pura Cungkub 1975, Pura Jugan 1975, Bale Kulkul in 1975-1976 (Lansing 1977:202). ${ }^{41}$ Kumpi literally means 'grandfather'; In the oldest inscription (104 Sembiran A I, saka 844) the term kumpi is used as a title to designate a honourable elder.

42 The Bujangga still have a separate burying place. All Bujangga males are alternately buried in one of two holes in the ground, while the Bujangga women are buried in the graveyard of the village.
} 


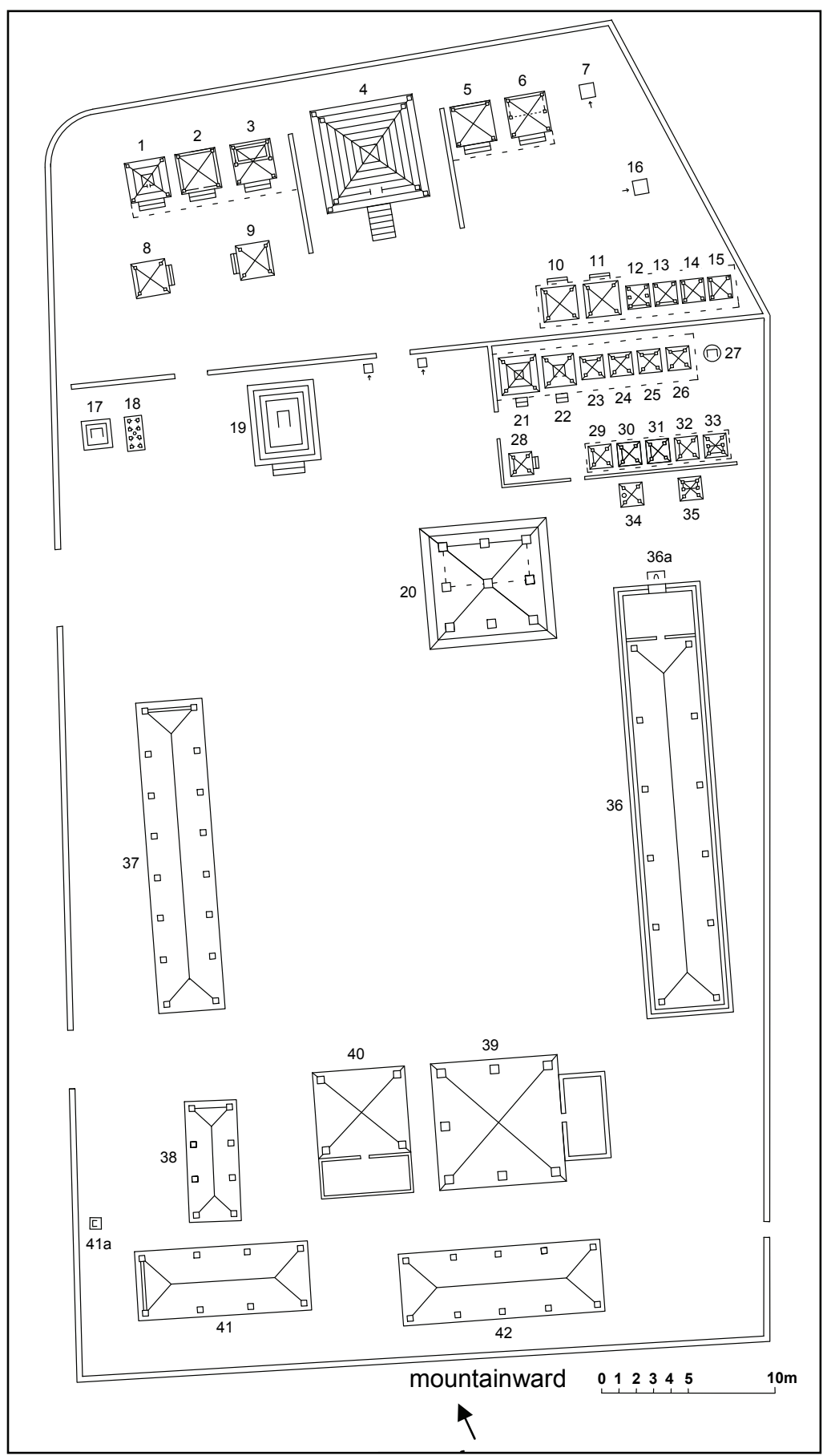

Figure 4: Ground plan of the Pura Desa/Bale Agung in Sembiran in 2005. 
Opposite the mountainward row of shrines is a second row, containing some platforms for offerings; three other temples are represented there too: Ratu Di Ngudu and Ratu Di Suksuk, two of the old guardian temples at the foot of the Sembiran hill. The third is Ratu di Pelisan, a temple used for purification rituals, located also on the edge of the sea.

The village temple (Pura Desa) seems to consist of three parts; today they look like separate units due to several partition walls. But the temple priests insisted that these parts constitute a single temple. The first compact part encircled by a wall has just been described. Actually the Bale Agung with the stone in front of it (Ratu Penyarikan) and all the other buildings sharing the same courtyard conveys the impression of a main courtyard of the whole temple complex: the meeting place of the paulun desa, the ritual elders of the krama desa and the temple priests, is located there as well as the padmasana, the lotus seat, a shrine erected in the $1990 \mathrm{~s}$ to meet suggestions for reformation and conformity with South Balinese standards. Formerly it was a simple open shrine called di dubur and dedicated to Sang Hyang Guru (represented by the sun) or Sang Hyang Tunggal.

In front of the Bale Agung are two shrines, one symbolizing a rice granary, jineng. ${ }^{43}$ The second is a small hall where palmwine, tuak, used in ceremonies, is stored. In the south-eastern corner stands the Bale Pegat, a shrine with a gap in between symbolizing the relationship between the world of the living and the world of the dead. Bale Pegat is a representative of the Pura Dalem, the Death Temple located seaward, outside the settled area of the village.

Opposite the Bale Agung is a pavilion for the wives (pelukayu) of the male krama desa members, called Bale Luh (no. 37). In the immediate neighbourhood is the Bale Daha (no. 38), the hall of the unmarried women (daba) who are joined in a separate organization. They have their special meeting day on Buda Wage. In the north-eastern corner is the hall (no. 41, Bale Teruna) of the unmarried men, teruna. Two open halls made of concrete west of Bale Teruna are the places for two different gong orchestras (Bale Gong and Bale Angklung) and, in the most northwestern corner the temple kitchen (no. 42, pewaregan) is located, where the butchering of the pigs and the preparation of all food offerings and ceremonial meals take place. The third part of the Pura Desa is separated by a wall from the other two parts. This third part is the most mountainward and consists of all the shrines beside the Pura Puseh. The Pura Puseh (no. 4) is a single shrine with a seventiered pagoda roof. ${ }^{44}$ Pura Puseh is separated by a wall from the other shrines on both sides. This part is the counterpart of the first section of the Pura Desa already described in so far as the former contains all shrines representing temples

\footnotetext{
43 The rice granary, today a tiny shrine, was formerly when rice could still be grown, a fullsized building; around 1960 it was replaced by the shrine.

${ }^{44}$ Temples of this kind, with tiered pagoda roofs, are already mentioned in the earliest Sembiran inscription (104 Sembiran A I, saka 844).
} 
outside of Sembiran territory, while the latter represents the inner structure of the village. The seats east of Pura Puseh all represent temples in the Batur region (nos. 1-3). West of Pura Puseh is a shrine for Pura Pucak Sinunggal (no. 5). This open shrine houses two ancient stone statues, a male and a female, said to represent the gods of the nearby mountain temple of Pucak Sinunggal. The next is dedicated to Dalem Balingkang (no. 6), a temple on the lower northern shoulder of the Batur caldera.

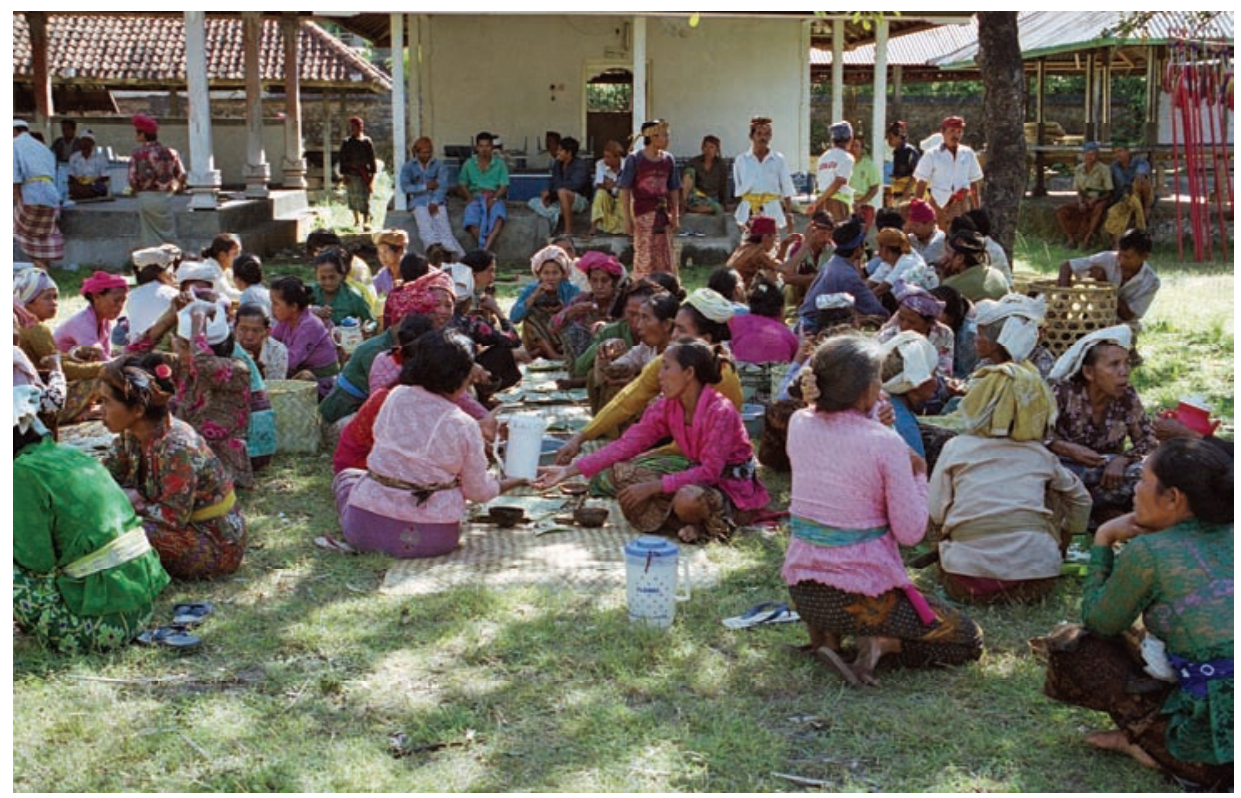

Photo 12: The female members of Sembiran's krama desa, are responsible for the manufacturing of offerings; women possess a seemingly endless repertoire of offerings and corresponding knowledge of the rituals they are intended for.

Photo: Brigitta Hauser-Schäublin 2001.

Further shrines are dedicated to Dalem Tajun/Bayad (no. 15) and to Ratu Candi (no. 11), the major deity of the regional temple of Ponjok Batu. ${ }^{45}$

The fourth temple of catur kabyangan is the Pura Dalem, located in a seaward direction and at a considerable distance from the village, just opposite the gra-

${ }^{45}$ Candi means royal grave monument. One of the shrines in the temple of Ponjok Batu bears this name. The sarcophagus excavated in the precincts of the temple of Ponjok Batu in the late 1990s seems to support this interpretation of the shrine for "Ratu Candi" in Sembiran's Pura Desa. 
veyard. ${ }^{46}$ Paul Wirz published a photograph of a temple in Sembiran. According to his description, in which he mentions the immediate vicinity of the graveyard, this could be the Pura Dalem. In the 1920s, when he visited Sembiran, this major sanctuary still consisted of menhirs erected on a stone terrace and fenced off by bamboo (Wirz 1928: plate 2). As Wirz noted, the graveyard was located on the edge of a thick forest.

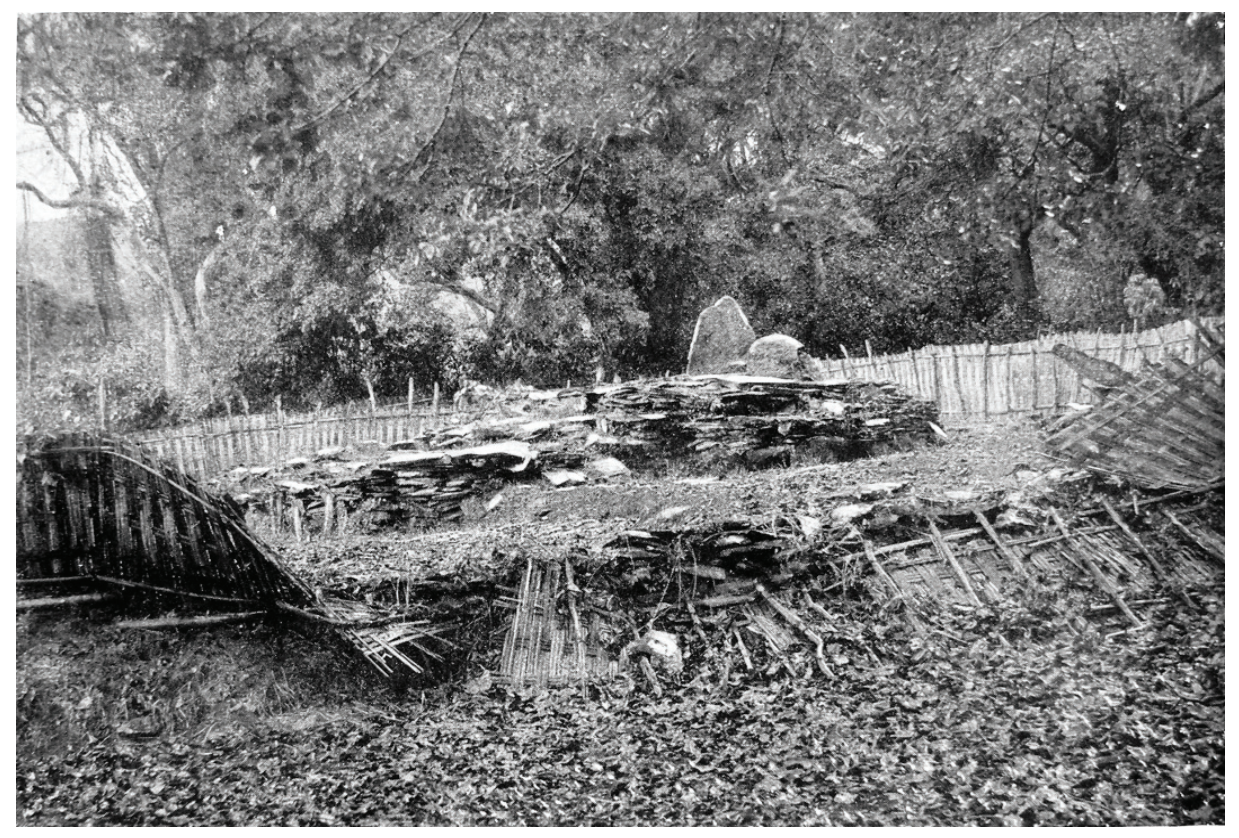

Photo 13: One of the major temples in Sembiran in the 1920s (Wirz 1928: plate 2).

The model of catur kabyangan, the four village temples, does not fit the South Balinese model of Kabyangan tiga, the three village temples, but reveals a Sembiran specific characteristic that is the outcome of the distinct history of this village. Oral histories hold that the Bale Agung was introduced only later. The meeting place considered the most ancient is the Bale Bundar (literally 'round hall' though the building is rectangular), this being the meeting place of the sekehe gede. The tower with the village kulkul (slit gongs) used for signalling important messages to

\footnotetext{
46 The graveyard has always been in this place. Sembiran is still described in travel books as not burying its dead. In fact, the bodies of women were laid out lying on their backs (women are symbolically identified with the earth, Ibu Pertiwi) and men lying on their bellies (being identified with the sky). The corpses, though not buried, were carefully disposed of. The practice came to an end in 1963 (Lansing 1977:196-197). Wirz reported in the 1920s that the dead bodies were said to be just thrown in a gorge to be eaten by tigers (Wirz 1928:5-6).
} 
the villagers (meetings, marriage, theft, fire, death, etc.) is located adjacent to this building. The Bale Bundar is today rarely used though still considered an important institution. Another Bale nearby is the Bale Banjar. When a death has taken place in the village, the sekehe gede meets in the Bale Banjar instead of the Bale Bundar.

In addition to the difference Sembiran displays with regard to the number of its major village temples, there is another characteristic to be pointed out.

As is well known (Covarrubias 1986, Swellengrebel 1984, Hauser-Schäublin 2004a), space is conceived according to an elaborate cultural model that defines directions of the compass associated with purity/impurity and higher and lower social standing. East and mountainward (in North Bali: south; in South Bali: north) are considered more pure and socially higher ranking than west and seaward. As a rule - or rather as an idealized model - a village and its major village temples should be built according to the conceptual model of space. The Origin Temple (Pura Puseh) is located on top of the village, the Village Temple (Pura Desa/Bale Agung) in the centre and the Death Temple (Pura Dalem) below the village in the most seaward position. If we try to apply this dominant model to Sembiran, we will realize that it is only the Pura Dalem that fits it. The Pura Dulu, for example, is located below the village, that is, in a north-western direction even of Banjar Desa, though on a hill. ${ }^{47}$ And most of the village spreads above Pura Desa/Puseh. The topmost temple is the Pura Dukuh, associated with the fertility of the fields. However this temple is not related to the origin of the village or its inhabitants. As oral traditions hold, this temple has been moved uphill at least twice in the not too distant past. Each time the village grew uphill and reached the vicinity of the Pura Dukuh, the temple was transferred to a higher location for the sake of purity. The site where the temple was formerly located is still remembered. These old sites are today in the middle of the village. Such translocations have not taken place with the Pura Desa/Pura Puseh or the Pura Dulu. They remained where they were once built with the result that the former is nowadays surrounded by houses, though at some distance.

\section{Historical Reasons for a Reverse Space Order?}

Apart from the location of these major temples, the position of many of the major shrines and halls do not fit the conceptual model of space either. In the Pura Desa, for example, the seat representing the Death Temple is in the most eastern position - while the section with all the shrines of the clan and village founders is in the most western part. Moreover, the Bale Agung is located in the western part, that of the women in the east. And, as for the members of the krama desa when they sit in two rows in the Bale Agung, the 'elder brother' line sits in the most

\footnotetext{
${ }^{47}$ Higher and lower follow the same principles of purity and impurity. In this sense, one could say that Pura Dulu, though situated seaward of the settlement, is placed on a higher and therefore purer location.
} 
western and the 'younger brother' in the eastern part. In a similar way this applies also to Pura Dulu since its shrines are all positioned towards the west. The graveyard (setra gede) ${ }^{48}$, although seaward of the village is east (and not west!) of the Death Temple. ${ }^{49}$ Thus, in these arrangements a kind of reverse order becomes manifest, an apparent preference of the west over the east, to which question even the ritual elders cannot give any explanation for this.

We can therefore only speculate as to why west was once important when the foundations of the temples (or those of their predecessors) were laid out. Probably it was not an abstract model that was decisive for the orientation of the temples and some of their shrines but, instead, concrete social relations which bound Sembiran to a place outside its village territory. In fact, the copperplate inscriptions give evidence of a Western orientation of Sembiran or rather Julah. In the royal edict of saka 897, the king Sri Janasadu Warmadewa declares the inhabitants of Julah to be responsible for the maintenance of his father's grave, named Baleswara, in the monastery of Dharmmakuta in the village of Bungkulan. A village bearing the name Bungkulan still exists; it is located some six kilometres west of Julah and belongs today to the district of Kubutambahan. ${ }^{50}$ Warmadewa further points out that the villagers of Julah, Indrapura (one of the villages near Pucak Singunggal, probably Depaa), Buwundalem (Bondalem) and Hiliran (Tejakula) are under the suzerainty (siwidharmman) of this sanctuary (sanghyang paryyangan), probably the monastery of Dharmmakuta which was near a port, called Manasa in the inscription. ${ }^{51}$ These villages had to pay taxes there and were obliged to provide Dharmmakuta with building material and services such as military defence in case of attacks. Today, neither Julah nor Sembiran have any relations with Bungkulan. Nevertheless, this inscription makes clear to us the far-reaching western networks that bound Julah and Sembiran (as well as other villages located even further east). As can also be gathered from this inscription, the royal seat was not located on the (dangerous!) coast but somewhere inland, probably in the mountains.

Today, Sembiran is still connected to "Indrapura", or rather the temple Indrapura was in charge of Pura Pucak Sinunggal. Pura Pucak Sinunggal is a mountain

\footnotetext{
${ }^{48}$ Apart from this graveyard there exists a special one for new-born babies and one for members of the descent group of the Bujangga. In many oral histories, even in the life history of the old man who told me how he had to leave the core village when only four daughters were born to him, there is mention of a graveyard near the coast, near the site where Ardika and his team made the archaeological excavations.

${ }^{49}$ Guermonprez notes a similar "inversion” in Julah (1998:56).

${ }^{50}$ In Bungkulan there still exists a nowadays privately owned temple with old sculptures and other ancient traces that could be proofs of the "Baleswara" or the monastery

Dharmmakuta; however, archaeological investigations would be necessary to ascertain this suggestion.

${ }^{51}$ It is still doubtful where exactly this harbour was. It could have been in the area of today's Sangsit, which undoubtedly was a port (see Ardika 1991:151). Today, there still exists a temple called Pura Manasa with a Ganesa sculpture in it near the village of Sinabun. From there a waterway directly leads to the coast near Sangsit.
} 
temple and is intimately related (phrased in terms of father and son) to the sea temple of Ponjok Batu. Pura Pucak Sinunggal is called "Si Tunggal" in another early copperplate inscription called "Prasasti Desa Depaa", (Goris 1954 no. 55), issued by the king Sri Maharaja Jayasakti (1133-1150). King Jayasakti addressed the edict to a domain called "Indrapura" (Ginarsa 1979).

I have already mentioned that one of the shrines in the Pura Desa's mountainward part and west of Sembiran's Pura Puseh is dedicated to this regional temple to which Sembiran still annually performs a pilgrimage. Pura Ponjok Batu today is even more important for both Julah and Sembiran; several times a year both villages perform pilgrimages to this sea temple. Its holy water (tirtha) is important in all rituals in which purification is a major issue. There is a direct path that links Pura Ponjok Batu with Pura Pucak Sinunggal and the deities of Sinunggal are received and welcomed a few hundred metres from Ponjok Batu before they are escorted to Ponjok Batu. The same applies to an ancient temple far outside Sembiran, formerly belonging to Desa Pintu, and located on the edge of the Yeh Lengis ravine, Pura Tegeh. This temple, still consisting of heaped stones (see also Sutaba 1985:15), was once the sanctuary where the deities of Pucuk Sinunggal were ritually welcomed before they were led to the village.

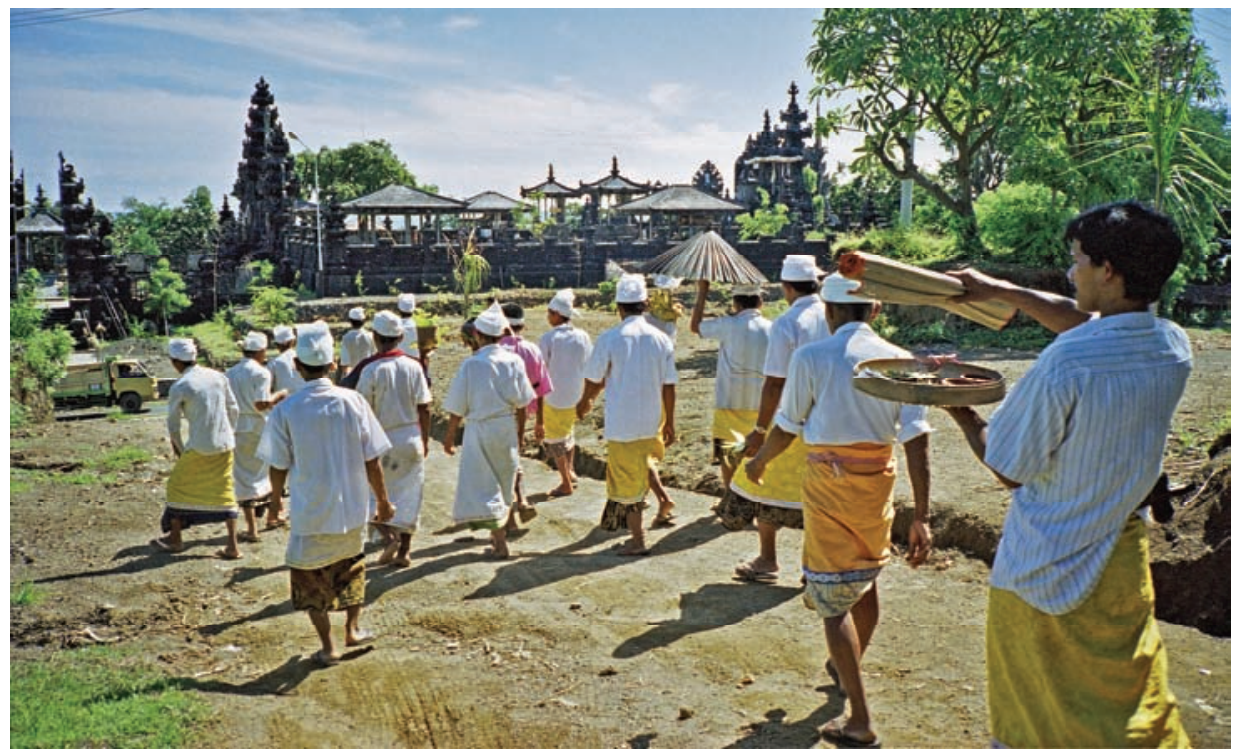

Photo 14: During the festival of the regional temple of Ponjok Batu the deity from the mountain temple of Pucak Sinunggal is called and escorted to the sea temple of Ponjok Batu.

Photo: Brigitta Hauser-Schäublin 1999. 
This close relationship between the mountain temple Pucak Sinunggal and the sea temple of Ponjok Batu is reflected in Sembiran's Pura Desa too: A shrine for Ponjok Batu (actually for Ratu Candi ${ }^{52}$, the most important deity residing there) stands opposite the shrine for Pucak Singunggal and in the immediate vicinity of a shrine for Dalem Tajun/Bayad. Dalem is the title of a ruling noble. ${ }^{53} \mathrm{I}$ have shown in earlier publications how such major regional temples attracted regional lords, even kings (Hauser-Schäublin 2003b, 2004b, 2004c, 2005). They attempted to put under their auspices influential temples of this sort that ritually united sometimes dozen of villages, and to act as sponsors or patrons. There are many indications that the temple of Pucak Sinunggal had been for a long time (certainly with interruptions according to the rise and subsequent disintegration of polities) under the sovereignty of a Dalem. When and how this came to an end is unknown. Pucak Sinunggal was an important regional temple that was linked to one of Bali's state temples, the Pura Ulun Danu Batur located south-east of both Sinunggal and Sembiran/Julah.

The temple of Pucak Sinunggal is said to today unite eleven villages; together they form a desa gebogan domas, an association of $800 \mathrm{KK}$ (kepala keluarga, that is, male family heads), although the sum of family heads outnumbers them by far. Each of these eleven villages has its special day when the villagers make the pilgrimage to this temple and bring not only offerings to the gods but also atos, tribute-like gifts.

In Sembiran and other villages there are a number of life-cycle rituals directed particularly towards a deified ruler called Dalem Tajun/Bayad. In one of these lifecycle rituals, each man who has been married for a number of years has to kill six calves for each of his wives. In both Sembiran and Julah this sacrifice takes place at a specific site quite some distance from the village in the direction of Pucak Sinunggal. I suggest that these rituals had their origins in certain taxation ceremonies requested by the ruler to be carried out by newly married couples. Seen from today's standpoint, this ceremony seems to have served two purposes: 1) the formal reporting of household heads and the number of their spouses provided a kind of demographic census. As is well known, the power of a ruler was based on the number of people (heads of households) who constituted his followers rather than on the size of his territory. The number of followers was expressed in rounded figures, 200, 400, 800 etc. (see Hauser-Schäublin 2004c).

\footnotetext{
52 The Sembiran B I inscription dated saka 873 mentions the landmarks of Julah's territory; one of these landmarks is named as candi, a term mostly used for a royal tomb (see fn. 44). ${ }^{53}$ This seat for Dalem Tajun/Bayad is said to be the seat for all Dalem (in this case: deified, that is ancestral kings) such as Dalem Mekah, Dalem Gelgel, Dalem Solo, Dalem Sindhu and Dalem Suraleya, who are also venerated in Sembiran.
} 


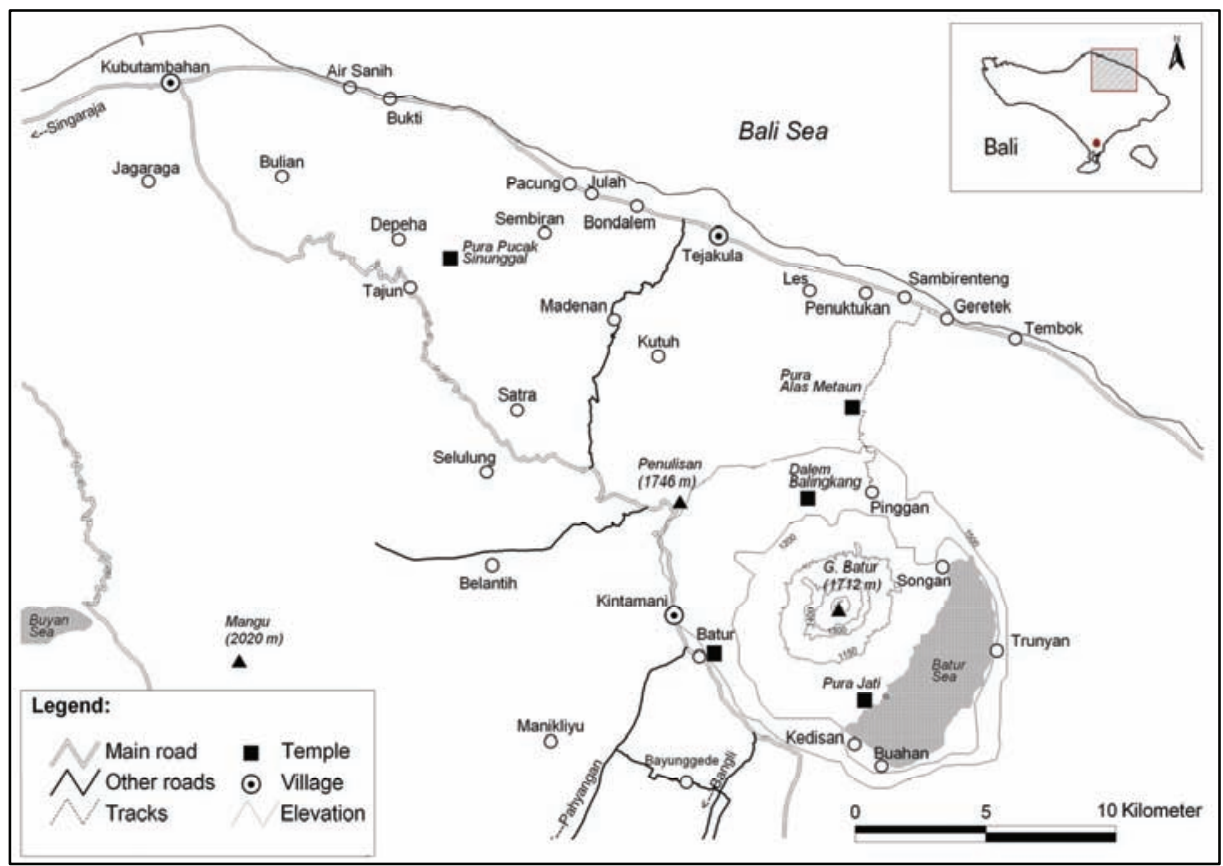

Figure 5: Area with regional temples into which Sembiran's temple network is embedded. Cartography: Enrico Kalb 2005; source: BAKOSURTANAL 1999.

It is suggested that this regional mountain temple or rather the lord nearby kept a kind of demographic register, resulting in the designation, for example of a gebog domas (set of 800), or a kanca satak (200), that is the number of people over whom the lord exerted some power. ${ }^{54}$ This interpretation is also supported by the practice of reporting deaths to this temple, which several villages still perform. 2) The sacrifice of a respectable number of calves throughout the year (there are set dates when the sacrifice should take place) seemed to have regularly provided the noble house with meat. This interpretation is supported by the copperplate inscription addressed to "Indrapura". King Jayasakti's edict testifies that the inhabitants of Indrapura were freed from a number of taxes and duties other villages were subjected to "because since the beginning they have had the special duty to slaughter

54 The copperplate inscription 409 Sembiran A IV, AD 1065, already mentions a temple and/or monastery called Hyang Slat Satak, apparently alluding to the number ( atak $=200$ ) of (male) heads of household attached to it. In this edict, King Anak Wungsu mentions a ceremony, sambar, during which the king has to be venerated. The inhabitants of Julah had to pay some kind of taxes to the official in charge of the sambar ceremony. This apparently important ceremony may be comparable to the ngusaba sambah, a ceremony celebrating the height of life and fertility, described by Français-Simburger for Tenganan (Français-

Simburger 1998). A whole network of villages is involved in this ritual. 
cattle" (Balinese transcription made by Ginarsa 1979). Today's regular slaughtering of calves could in fact have had its origin in such a tax in kind.

From the examples drawn from the copperplate inscriptions issued between the $10^{\text {th }}$ and the $12^{\text {th }}$ century, we can conclude that Julah/Sembiran had a strong westward orientation. The westward positioning of today's temples and shrines in Sembiran might go back to such historical circumstances. This example also shows that Sembiran was not an isolated village but was part of a far-reaching ritual and political network. Some oral histories still give evidence of such networks (see p.31).

\section{The Relationship to a State Temple}

Apart from Pucak Sinunggal to which both Sembiran and Julah are still linked, the six copperplate inscriptions ${ }^{55}$ themselves definitely point to the Batur Region as I am going to show. Testimonies of such far-reaching relationships can be found in one part of Sembiran's village temple. The mountainward section of Pura Desa is dedicated to temples beyond the village territory - except for the highest-ranking (seven-tiered) shrine that represents the shrine of origin (Pura Puseh). ${ }^{56}$ The shrines east of Pura Puseh are representations of temples quite a long way off, those in the Kintamani area (Kabupaten Bangli), namely Batur. The Batur temple (Pura Batur Ulun Danu) is, as already briefly stated, one of the most important state temples in Bali; it is located in the central mountain range near the Batur volcano and the crater lake. Thousands of pilgrims from Bali and beyond flock every year to this temple when the festival of the tenth Balinese month takes place; the flow of pilgrims lasts for several weeks. The temple is associated with the control of the flow of water (the crater lake being the largest water reservoir of the island), essential also for irrigation agriculture. The pilgrims progress to this mountain sanctuary where they pray for the blessing of the gods and especially for prosperity and fertility. They carry along large amounts of offerings and gifts dedicated to the Batur deities and their temple and receive holy water, tirtha, in turn. As I have shown elsewhere the Batur temple was also a redistributional centre (Hauser-Schäublin 2003b, 2004c, 2005, in press).

\footnotetext{
${ }_{55}$ Brandes mentioned that, apart from the copperplate inscriptions then all still kept in Sembiran, there were 150 pieces of roundish metal (coins), two antique golden finger rings (one similar to a signet ring with a cut elephant), some golden miniature tools for handling betelnut ingredients, and two copper arm and ankle rings (Brandes 1890:19-20). The rings and the miniature tools have disappeared since; some of the coins are left. In the interest of security I shall not mention where they are kept; over the past ten years break-ins in temples and the stealing of sacralia later sold on the international art market seem to take place every week throughout Bali. Even the 10 copperplates kept in Julah were stolen a couple of years ago but fortunately recovered in Java before they left the country.

56 This shrine of origin - clearly separated from the other "external" shrines by a wall probably has to be understood as an attempt to attach the "foreign" to one's own or rather to put one's own in the centre of an extra-village universe.
} 
The ritual organization of the state, with temples acting as a kind of tax-collecting institution and redistributional centre under the auspices of the king, seem to constitute a very old principle. As the edicts of King Sri Janasadu Warmadewa (saka 897) and of Queen Sri Sang Ajnyadewi (saka 938) addressed to the villagers of Julah show, the people of Julah were asked to provide a temple (or rather the monastery of Dharmmakuta) with a whole list of tributes or tax in kind and in gold once a year (the month of Kartika, today the fourth Balinese month) and on each occasion of "Rah Tirtha" in the month of Kartika, as the edict of King Warmadewa specifies. The name of this occasion, apparently a ritual in which holy water (tirtha) was distributed, seems to suggest a similar exchange of taxes or tributes in kind and money that today's pilgrims bring to the Batur temple, receiving in exchange tirtha. A further edict (saka 987, Sembiran A IV) mentions that the villagers of Julah had approached the king for his blessing apparently transmitted also in the form of holy water ("nugrah titisanammr", translated by Ardika and Beratha as "anugrah tetesen or air kebidupan").

The people of Julah had asked the king to have his edict written on copper plates ${ }^{57}$ again on a day the sambar ritual was held and when he was apparently present. ${ }^{58}$ The intertwining of ritual and politics, of holy water and taxes, therefore indeed seems to be a basic trait of the organization of Balinese stratified polities.

Today, the Batur temple is part of a whole network of temples. ${ }^{59}$ One of the most prominent in this network is Pura Jati, apparently once in charge of Buddha priests. ${ }^{60}$ The oral traditions hold that the last Buddhist (or Bujangga) leaders surrendered their power and, consequently, the temple, to Dang Hyang Nirartha, the brabmana cultural hero who brought brabmana teachings and the brabmana caste in the $16^{\text {th }}$ century to Bali. In pre-colonial times Pura Jati was responsible for officially determining and announcing the beginning of the new saka-year that starts around July/August. The determination of the New Year was essential for the synchronization of the agricultural cycle - and all the fertility rituals held in temples throughout large parts of Bali. Sembiran played an important role in this, the role of the star watcher. Since the sky is often clouded in the mountains it was

57 The smiths (pande) as a special group (see Guermonprez 1987) have a prominent position in Batur with regard to the location of their temple but also with their shrine in Batur's Pura Desa. Today, there no longer exists any link between the profession of smith as such or his products and the members of the group. Unfortunately we have no information where and who produced the copper plates for the inscriptions.

58 The villagers had argued that palm leaf (on which he had probably written an earlier edict) was too easily perishable.

59 The Batur temple as an institution is no more than a couple of centuries old. One of the most important temples at the time of the royal edicts written on copperplates was the temple of Da Tonta in Trunyan (see Dananjaja 1980 and Ottino 1994, 1998).

60 This temple is today completely integrated in the temple network of Batur village. However, this Buddhist temple, or probably rather monastery, had its own network. There exists - perhaps among others which I did not come across - a sacred place (today a temple) in Bungkulan (see footnote 50) that holds a water beaker with zodiak symbols considered to be a heirloom of the temple's intimate relation with Pura Jati. 
difficult to determine exactly the rise of the stars. Sembiran still has a small temple (Pura Peninjoan) where the ritual leaders of the village watched for the rise of the Pleyades, kartika. ${ }^{61}$

As soon as the stars appeared they brought the news to Pura Jati that then set up the New Year ritual in which Sembiran participated. This was the beginning of a year-long cycle of rituals in Batur in which dozens of villages participate. The calendar Pura Jati set up was directive for all villages that followed the Batur cycle.

There is evidence that each village tied to Pura Ulun Danu Batur by a special bond, called pasyan, had a representative in Batur, too. Conversely, the (formerly) most important priest, the Mangku Gede (already mentioned), has to be understood as a ritual representative of the Batur temple in Sembiran. Moreover, when one of the (two) leading priest(s) of Pura Ulun Danu was consecrated, he made a visit to important sea temples, often Pura Ponjok Batu, and certain villages to ask for recognition; Sembiran was one of these.

Today, after decades of rapid change that has taken place in Sembiran, only shadows of what probably once constituted the relationship between Sembiran and the ritual centre in Batur can be sketched. The most evident - the material ones - are found in Sembiran's Pura Desa: Shrines dedicated to deities or temples in Batur. Two of these embody double aspects: they have a local counterpart and they share the same shrine (ngerok). They form pairs though each of them has its anniversary celebrated on a different day. Shrine no. 1 (fig. 4) is dedicated to the Pura Ratu Mas Agung Susunan ('The Temple of the Great Radiating Ruler')/Ratu Gede Sakti ('The Great Powerful Lord'), both located in Batur's main temple; its local (Sembiran) counterpart who resides in the same shrine is Ratu Meduwe Karang ('The Lord Who Owns the Village'). If Sembiran's ritual leaders return from a pilgrimage to Batur they deposit the holy water there. Shrine no. 2 is dedicated to I Ratu Ayu Gunung Sari, 'The Supreme Female Deity of the Batur Volcano'.

${ }^{61}$ Proudfoot stressed the facts that astronomical observations served as adjustments to the Indic calendar (2007:95). 


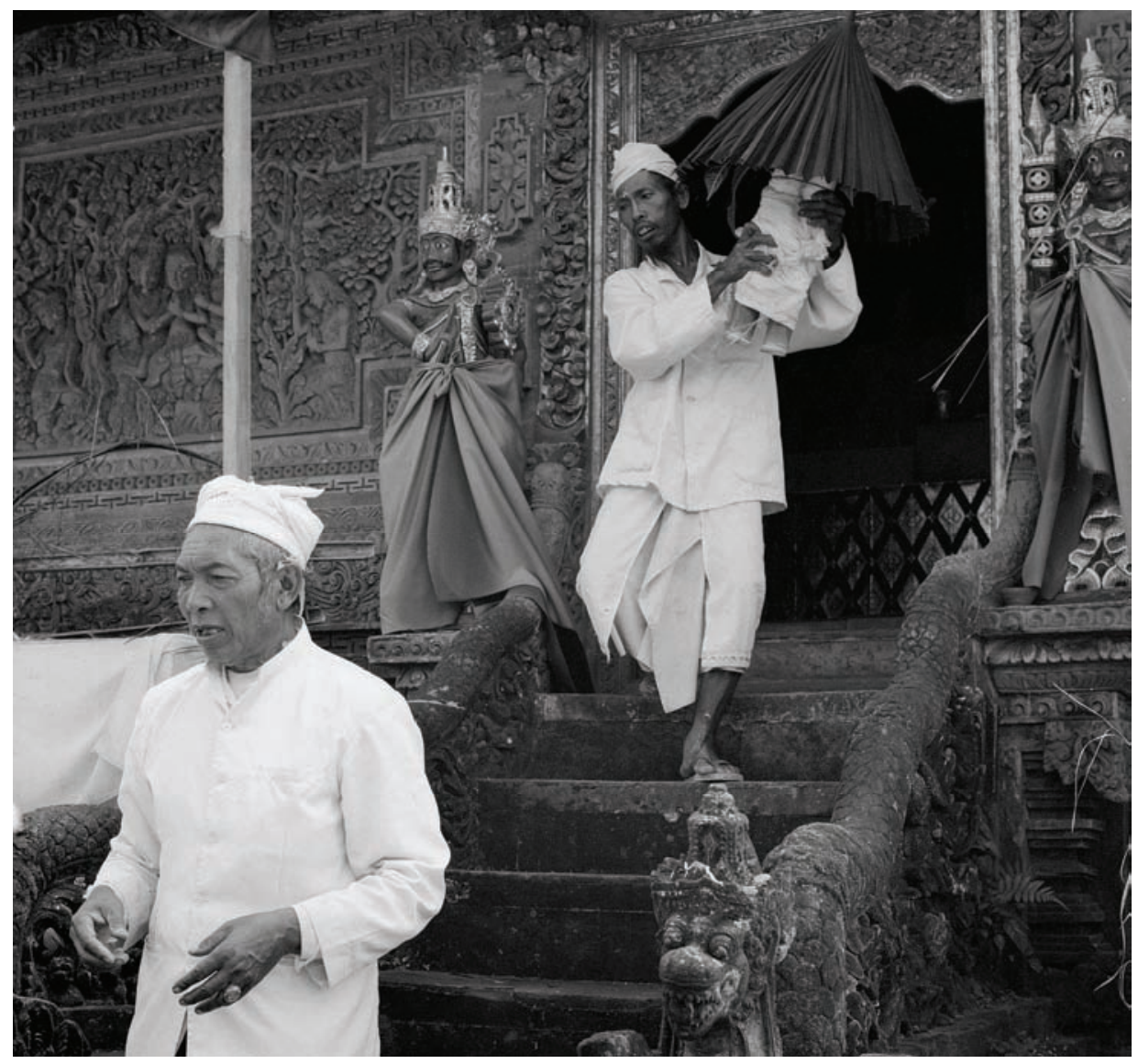

Photo 15: The Mangku Gede of Sembiran leading the delegation from Sembiran is allowed to receive tirtha (holy water) from one of the major shrines of the Batur Temple.

Photo: Jörg Hauser 1998.

Shrine no. 3 represents Gunung Lebah ${ }^{62}$ (the name of a defunct village near the Batur volcano) and also Ratu Ngurah Rungkin, a deity of Pura Jati on the border of the Batur lake. When Sembiran's ritual leaders fetch holy water from Pura Jati they deposit it there. Their local counterpart is Ratu Bagus Pura Agung, the deity associated with Sembiran's former harbour and the trade relations with Batur (see p.27-28), or rather today's Kintamani area where one of the most important transregional markets is still held every third day.

62 The volcano today called Batur mountain had many names in pre-colonial times:

Gunung Sari, Gunung Tampurhyang, Gunung Kederan, Gunung Sinarata, Gunung Lebah; the latter name means "the low mountain" or "the mountain below" alluding to the Batur lake. 
The temple of Ulun Danu displays a shrine dedicated to Ratu Subandar, the deified harbourmaster. Subandar (see above) were mostly Chinese and this shrine is thought to be Chinese as well. It is regularly visited by (Buddhist) Chinese. An intimate link between market and temple as well as between merchants or harbourmasters and king is spelled out in many locally told oral histories about a Balinese king (mostly called Jayapangus) and the daughter of a Chinese harbourmaster (sometimes the woman is said to be a Chinese princess). The first three of the royal edicts addressed to Julah dated saka 844,873 and 897 respectively were explicitly written on the market day (pasaran) at the most important market place when the king apparently held audiences there. ${ }^{63}$

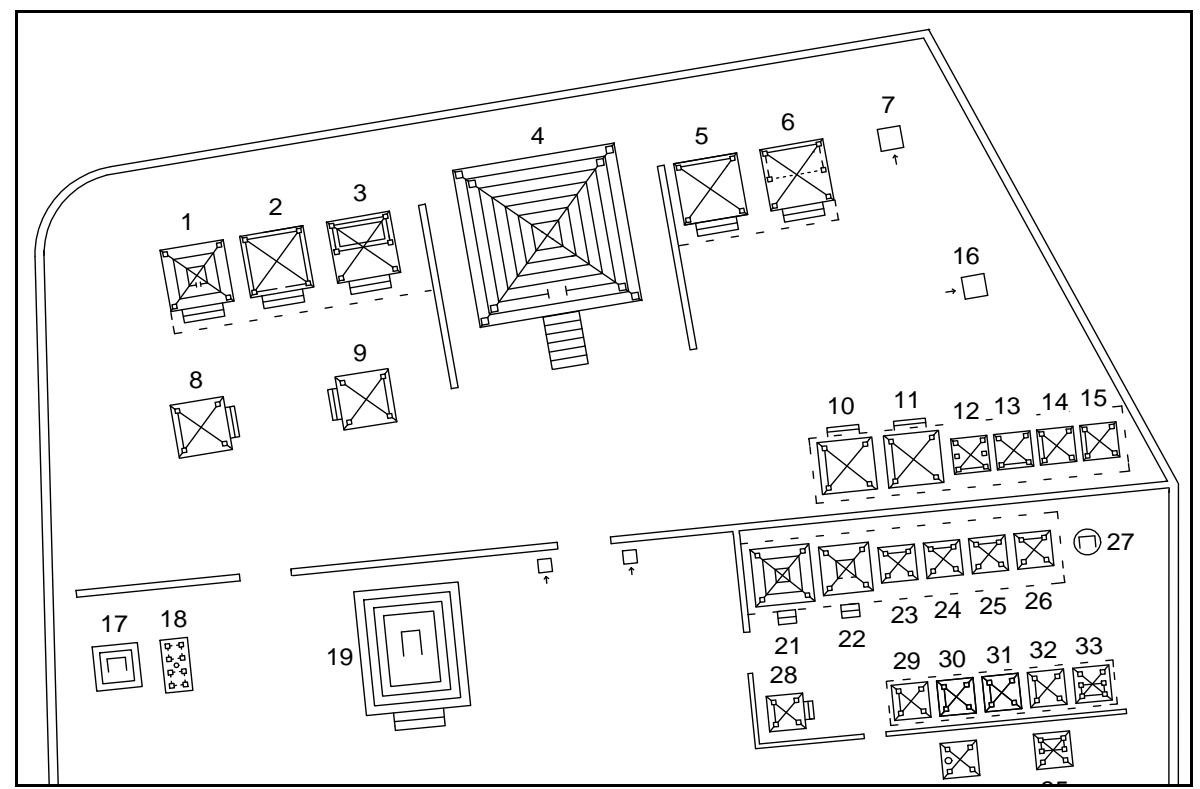

Figure 4. Pura Desa with Pura Puseh, Sembiran, upper part. Shrines dedicated to deities both from Batur (B) and Sembiran (S); some of them (cooperating partners) 'own' a shrine together: 1) Pura Ratu Mas Agung Susunan/Ratu Gede Sakti (B), Ratu Meduwe Karang (S); 2) Ratu Ayu Gunung Sari (B); 3) Gunung Lebah/Ratu Ngurah Rungking (B), Ratu Bagus Pura Agung (S); 4) Pura Puseh; 5) Ratu Ngurah Balingkang/Gunung Agung; 6) Pura Pucak Sinunggal; 8), 9), 10) open shrines for offerings; 11) I Ratu Ngurah Candi (Pura Ponjok Batu); 12) Jineng (granary); 13) Tampa Lawang; 14) Ida Bhatara Bagus Wayan (B); 15) Dalem Tajun/Bayad, 21) Ratu Pasek.

${ }^{63}$ The names given for these places do not allow any identification. 
The temple shrine in today's Sembiran's Pura Desa that houses the copperplate inscriptions has its annual festival on the first full moon of the Balinese year - on the same day as the Batur temple celebrates its annual festival in its temple of origin (Pura Puseh). And it is on this very day that the copperplate inscriptions are ritually cleansed. ${ }^{64}$ On this same occasion, Ratu Meduwe Karang (the local counterpart of the most important Batur deity, Ratu Agung Susunan, both sited on shrine 1), Ratu Ngurah Rungking (fig. 4, shrine 3), and Ratu Pasek (fig. 4, shrine no. 21), the deified ancestors of the Mangku Gede, celebrate their annual festival in Sembiran's village temple. The holy water fetched from Batur is put in one of these shrines on one day and then moved to the shrine where the copperplate inscriptions are housed on the next. Later, at the climax of the ritual, the holy water is distributed to the congregation, too.

The ritual practices and the main temple of Julah express a similar relationship to Batur as Sembiran. The highest shrine (eleven-tiered roof) in the mountainwardeastern section of the temple is indirectly associated with Batur. Formerly, it housed a crown and a ring both designated as a royal gift. They are considered to be part of the sacred heirlooms to which also the copperplate inscriptions belong. Two edicts (saka 844 and saka 987) already mention a ring (cincin singhala) that was given to Julah as a royal gift. Brandes noted a signet ring with a cut elephant (see also footnote 55) among the sacred paraphernalia kept in Sembiran. In Julah the ring and the crown were stolen in the 1960s or the early 1970s for the first time. ${ }^{65}$ The shrine still houses several other heirlooms, among them ancient sculptures of a godly or royal couple. These statues and Julah's share of the copperplate inscriptions are ritually cleansed at set dates when major festival days are held in Batur. Before the cleansing ritual a delegation of ritual elders fetches holy water from Batur, too.

Thus, at every ritual involving the copperplate inscriptions and/or the sculptures the intricate relationship with Batur and their supreme gods is renewed. At the same time a kind of communion between Batur and the people of Julah is achieved: the ritual elders distribute the holy water from Batur as well as that used for the cleansing of the sacred inscriptions and the statues, to the worshippers, who sip it. Similar conditions apply to Sembiran.

\footnotetext{
${ }^{64}$ On the occasion of a temple festival, the holy scriptures, today usually written on rontal (palm) leaves are publicly read. This was probably done in former times with the Sembiran inscriptions, too. When the ability to read them was lost, attention may have shifted to the cleansing process.

65 The crown was reproduced and in the late 1990s stolen again - and reproduced again.
} 


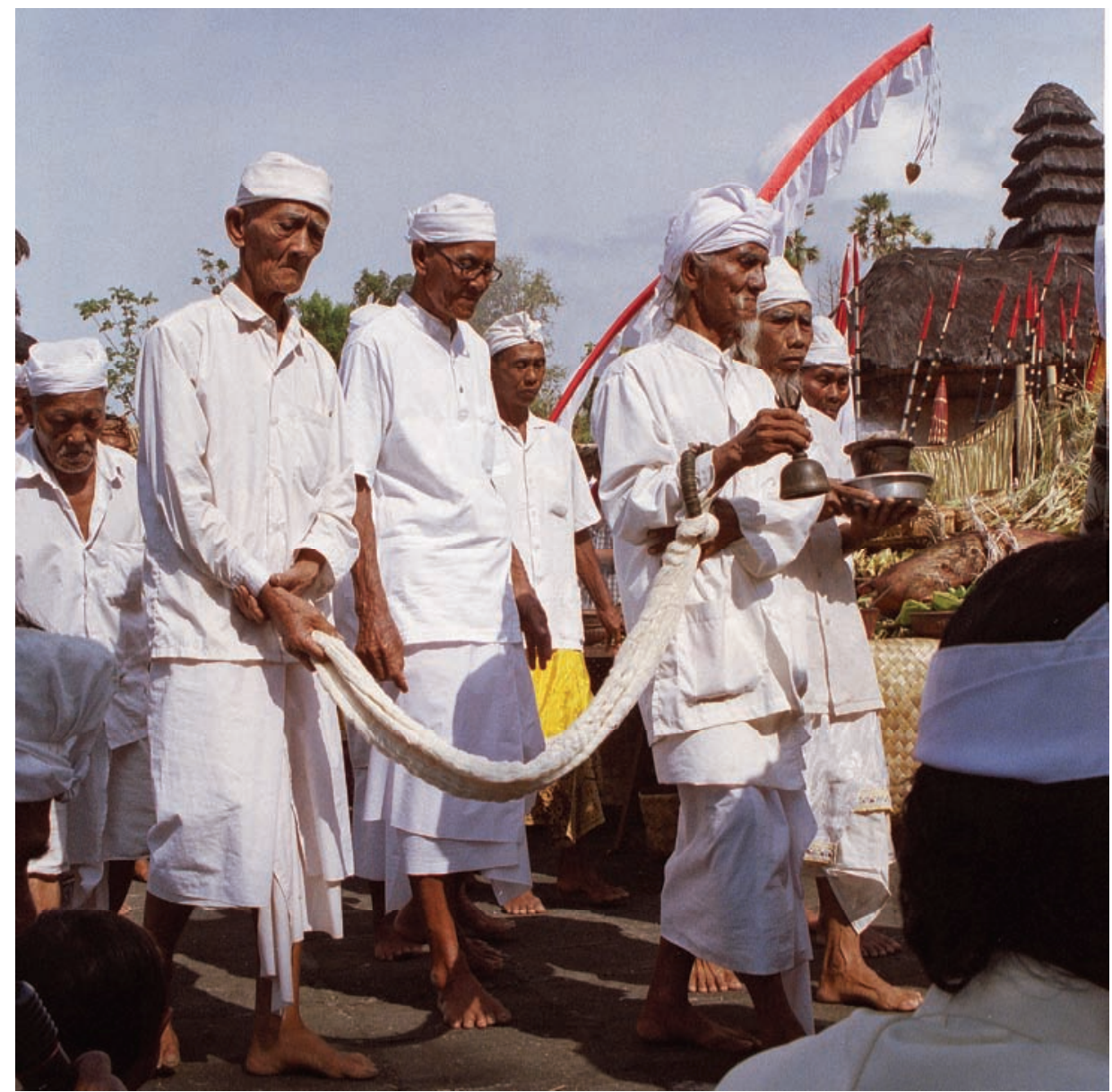

Photo 16: The kubayan, the ritual leaders in Julah, walk the offerings round. The leading kubayan has a thick skein of white cotton tied by an armband of Chinese coins to his wrest.

Photo: Brigitta Hauser-Schäublin 2003.

In the course of the year, the ritual leaders of Sembiran make a further pilgrimage to the Batur area in order to ask for holy water. This takes place in a later month when the crops in the gardens (mainly dry rice, gaga, in former times) have reached a delicate stage immediately before the harvest. The holy water is supposed to ensure fruitful growth and to ward off pests. On the last month of the year (around April), it is Batur who asks Sembiran (and many other villages) to come and bring along offerings and a wide range of the produce of their labour (rice, coconuts, raw cotton, pigs etc.). These goods clearly have, as briefly mentioned above, the character of tributes; they are listed in several palm leaf manuscripts kept in the Batur Temple (see Budiastra 1975 and 1979). 
These lists are not only addressed to Sembiran but to a great number of villages considered to be supporters of this major state temple in the mountains. Whether the lists of gifts contained in the royal edicts already mentioned (starting with the earliest, saka 844) are a kind of predecessor of these palm leaf manuscripts cannot be determined. Nevertheless the similarity of the gifts Julah formerly had to deliver - among them, most prominently, raw cotton - is striking if compared with those listed for Sembiran in the Batur manuscripts. ${ }^{66}$ One of the royal edicts (saka 938) apparently mentions offerings that had to be tied to a bamboo pole (gantung dulur); this is still done today, too, when specially made cookies symbolizing stars have to be brought to Pura Jati for the celebration of the beginning of the New Year. Following this, a number of these offerings are tied to a bamboo pole and transported to the temple near the Batur volcano.

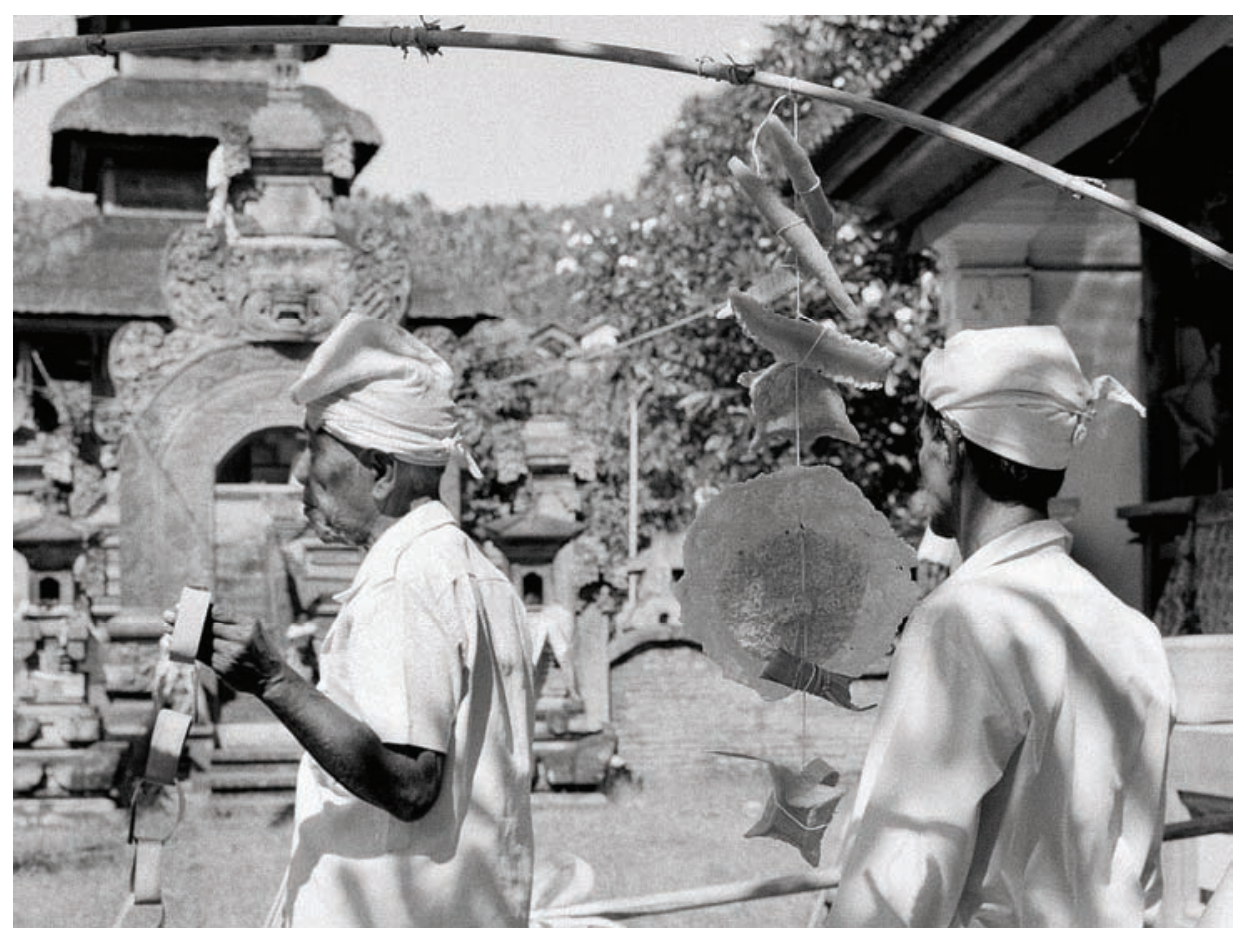

Photo 17: Before the celebration of the New Year takes place in the Pura Jati near the Batur Lake, Sembiran's members of the krama desa prepare special offerings (note the cookies) that are fixed to bamboo poles and then carried across the mountains to Pura Jati.

Photo: Jörg Hauser 2003.

${ }^{66}$ It might be surprising that Julah is not mentioned in all the Batur tribute lists; I suggest that they were (re-)written (or copied) when the (surviving) inhabitants fled to Upit sometime in the $18^{\text {th }}$ century and were considered part of Sembiran village (see above). 
However, while between the $10^{\text {th }}$ to the $12^{\text {th }}$ centuries it was the king who requested a list of specific products from Julah, it is evident that nowadays it is the temple and the temple authorities who ask for the tributes. In exchange for these goods Julah's and Sembiran's deputies receive holy water, too. In Sembiran there exists a special temple, Pura Peken (literally meaning 'Market Temple') ${ }^{67}$ located above the village at a site from where the track to the mountain starts.

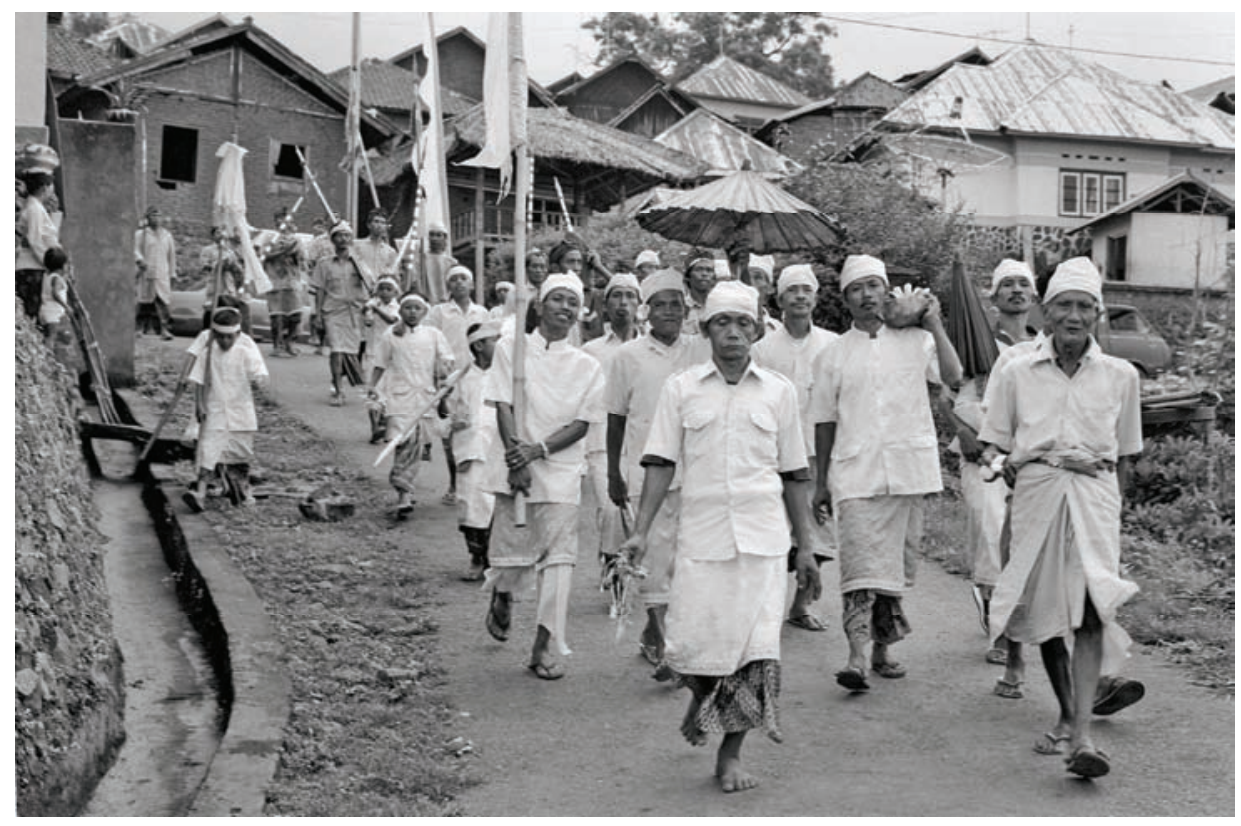

Photo 18: The holy water from Batur is first brought to the Peken ('market') Temple in Sembiran. It is then ritually escorted by the elders to its final destination, the village temple.

Photo: Jörg Hauser 1998.

In this temple the holy water from Batur is always first brought and venerated before it is then taken in a solemn procession to the village temple. As soon as the tirtha from Batur reaches the Pura Desa, the village celebrates the annual festival of two of its shrines dedicated to Batur.

There seems to have existed a two-way relationship between the temple supporting villages, pasyan, ${ }^{68}$ and the Batur temple consisting of a movement from the periphery to the centre and one from the centre to the periphery. Apart from

\footnotetext{
${ }^{67}$ Asked for an explanation of this name some elders explained that Pura Peken is a temple exclusively dedicated to the (ritual) exchange relations between Sembiran and Batur. ${ }^{68}$ According to the linguist I Nyoman Suarka, Universitas Udayana Denpasar, pasyan is etymologically related to sisya meaning religious disciple (personal communication).
} 
pilgrimages the pasyan regularly performed (periphery to centre), a delegation of the temple, accompanied by the symbols of the gods, made a procession to the villages of the pasyan. Therefore, the gods of Batur went on a procession as far as the villages at the periphery that had shrines representing the Batur temple or one of its deities - but never beyond. The progress, therefore, served also the reconfirmation of the ritual territory. ${ }^{69}$

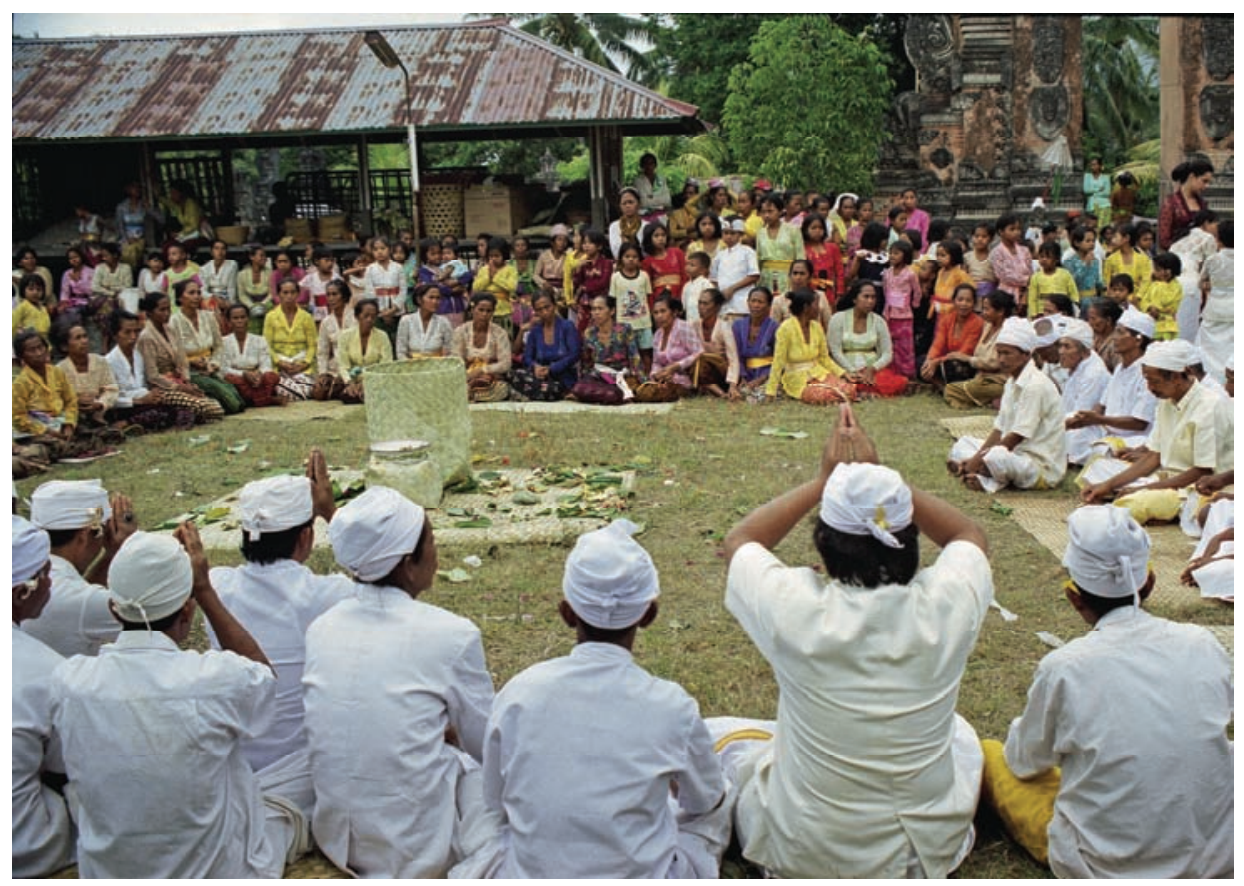

Photo 19: The amblangin ('census') ritual is performed both in Julah and in Sembiran. Each household has to deliver as a kind of tax a fixed amount of Chinese coins (accompanied in Sembiran by cotton, dried beans and rice). This tax is no longer paid to higher institutions beyond the village boundaries. Photo: Brigitta Hauser-Schäublin 2001.

These villages apparently considered these visits, when the temple authorities brought symbols of Batur's deities along, to be an honour or even a favour. The texts describe various taxes to be paid by the villages to the visiting gods, the amount of money depending on the standing of deities, those representing Batur's

${ }^{69}$ In one of the palm leaf manuscripts (Pratekaning Usana Siwasasana, $\int 14 \mathrm{~b}$ ) the area of the pasyan is outlined as follows: on the north coast it reaches from today's border between Buleleng and Karangasem to Singaraja, in the southwest and the south to a river (Yeh Sumi), which forms today's border between Tabanan and Badung; to the east to Klungkung (Yeh Unda). 
major deities (both of Pura Batur and Pura Jati) being among the most "expensive". According to different lontar texts kept in the Pura Ulun Danu Batur (see Budiastra 1975 und 1979), this ritual tax collecting (tax in kind as well as in money) was called ambalangan (Babad Patisora \42a), ablagung (Pangacin-acin Ida Bhatara \50a), or ambalangan (Pratekaning Usana Siwasasana \74b). Today such visits no longer take place, at least not, as far as I know, to villages on the north coast $^{70}$. However, both Julah and Sembiran still perform rituals called amblangan or ngnamblangin, too; they are locally translated as "census", or "to enrol". During these rituals carried out in the major village temple, each household has to contribute a certain amount of Chinese coins, rice, dried beans, and unprocessed cotton - the same goods to be brought to Batur. Today, the money is transferred to the treasury of the ritual village association and used for further ceremonies. The rice is used for a ceremonial meal of the village ritual association. This wealth therefore no longer flows back to Batur.

There is a further shrine in Sembiran's Pura Desa that represents the outbound relations of this village. The shrine stands immediately west of Pura Puseh and represents a temple on the caldera rim of the Batur volcano, Pura Dalem Balingkang. Apparently Pura Dalem Balingkang was tied into a network similar to Pura Ulun Danu Batur. However, there seemed to have existed a rivalry between the temples of Dalem Balingkang and Batur with regard to the supporting villages. Dalem Balingkang is considered in large parts of north and central Bali to be the site of the first Balinese kingdom with a palace (puri) there (see also HauserSchäublin 2004c). ${ }^{71}$ Today, this temple is revitalized by descendants of noble houses as well as by politicians, and the authorities have started to "invite" villages to join the annual temple festival.

This paragraph has shown to what extent both Sembiran and Julah were and still are embedded in political and ritual networks, the latter village today only to a limited extent since it deliberately denies any "dependency" from places outside of its territory. Temples, shrines and the respective naming of the deities residing there as well as the ritual practices and oral histories provide proofs of these net-

\footnotetext{
70 The temple Pura Gunung Lebah in Campuan (Ubud) which, as the name suggests, is dedicated to the Batur deity, invites Bhatari Dewi Danu to its temple festival when it is celebrated on the highest level with a water buffalo as a sacrifice. The goddess represented in a tapakan, a flower symbol, is led from the Batur temple to Campuan where she resides for the duration of the festival in the temple there. The highest temple authorities from Batur, the two Jero Gede, then visit the temple as well. I suggest that this may be the model for such visits as described in the lontar texts.

${ }^{71}$ The palace is said to have been originally located on the Batur caldera rim, in Kuta Dalem (near Sukawana) and just a few kilometres off from Dalem Balingkang. During an earthquake this site was completely destroyed and the palace buried under the landslide (see Reuter 2000a).
} 
works that are vital for the understanding of the socio-political and religious organization of the villages in question.

\section{Between Stratification and Equality, Regional Integration and Autonomy}

The fact that Sembiran and Julah (as well as many other villages) were (and partly still are) expected to provide temples and temple authorities with goods and labour (for temple renovations and the preparation of festivals) makes it clear that these networks were not free from questions of power and authority. After the collapse of the kingdoms (enforced by the Dutch colonial power) the temples became more or less cut off from the ties that existed between them and the royal houses (cf. Hauser-Schäublin 2003, 2004b, 2005, in press). ${ }^{72}$

As already mentioned, the Sembiran copperplate inscriptions give evidence of the fact that Sembiran was once a highly complex and even stratified society between the $10^{\text {th }}$ and the $12^{\text {th }}$ centuries. The social structure and socio-political organization were continuously fluctuating, no doubt as a consequence of continuous interactions (of different forms) with foreigners and immigrant groups. Reintegration into larger polities and stratification and disintegration and processes of destratification seem to have continuously followed one another. It is impossible to clearly outline these processes; they can only be illustrated with examples that give insight into the socio-political preconditions in which they were set.

Since colonial times various authors interpreted the krama desa (village association) as a manifestation of an aboriginal egalitarian socio-political organization. What Korn (1984) already pointed out in the case of Tenganan but as Reuter (2002b) has convincingly shown for a large number of mountain villages, at the core of the organization of the communal life was a dualism, the division of the adult members of the ritual village association into two ceremonial moieties on the model of elder and younger (or right and left). These moieties (sibak) are the basic cooperative units that complement each other. Every ritual can be achieved only through mutual cooperation of both moieties.

Whether a dual organization similar to today's village association already existed at that time documented by the copperplate inscriptions is difficult to say. Nevertheless, the term karaman, which seems to be identical with today's krama, is mentioned from the first edict, dated saka 844, to the last, the saka 1103 inscription. It seems that this institution has had an astonishing persistence, although without

\footnotetext{
72 These ties have recently, as a consequence of Indonesia's move to political decentralization, been re-activated.
} 
further evidence we cannot conclude that there was continuity in structure or organization.

However, dualism is not restricted to "primitive" or aboriginal social organization; it can be the result of a process that Friedmann has called devolution in the context of his analysis of the Katchin in Burma and the transformation from the gumlao to gumsa type of social organization (Friedmann 1998). Moreover, duality can serve as the basis for complex political organizations. Dualism is, as Southall (1956) emphasized, a characteristic feature also of the segmentary state since it serves vertical integration at a higher level of organization. As I have demonstrated elsewhere, the villages were embedded not only in a wider geographical but also in a political context in corresponding power relations. When the ritual community of a village acts beyond the village level, as, for example, at a ceremony in a regional temple, the moieties no longer play any role. It is the village as a unified body that becomes represented (Hauser-Schäublin 2004c).

Nevertheless, Sembiran's krama desa is not the only village organization that has existed since pre-colonial times. As Stephen Lansing already pointed out (1977:28), Sembiran has a unique institution, the sekehe gede (The Great Association, also called Desa Gede, 'Big Village'), in which members of all clans (dadya) are represented. In this respect, Sembiran indeed seems to differ substantially from other villages, even from Julah. The sekehe gede goes back to the two immigrants whose stories have been rendered above: Ratu Subandar/Pesisir and Ratu Kamasan; the sekehe gede was headed by them. In contrast to the krama desa, the sekehe gede is an encompassing organization where people or rather localized units ("clans" or dadya) are included without regard to their ritual practice (originally whether slem or kala, that is either 'Islam' or 'Hindu'). As will be remembered, the krama desa was the organization of the original inhabitants with whom the immigrants came into conflict with regard to the rituals practices they brought with them. The sekehe gede seemed to be one of the compromises or solutions the two parties achieved. The sekehe gede displays features of an administrative or political organization; its goal or function is to integrate different groups (autochthonous and immigrants) and to establish and maintain social order. ${ }^{73}$

Today, the sekehe gede has two meeting places, one south of the village temple, the Bale Banjar, and one east of it. The meeting in the Bale Banjar/Bale Bundar takes place every month at tanggal ping pitu (seven days after the moon eclipse). The eastern meeting place was turned into a temple recently and is called Pura Jugan (jugan-meeting). Pura Jugan is explained as the place "where a ratu [sovereign] lived, received his guests, and arranged meetings."

\footnotetext{
${ }^{73}$ After the colonial government separated customary life (adat) from colonial administrative life (dinas), the sekehe gede was moved to adat and therefore lost its function of integrating immigrants.
} 
To this day, there still exist two offices, that of the praejuru desa (village official, praejuru literally means 'warrior') and the klian desa (village head); these, with some assistants, constitute a kind of governing body. They are elected in the Pura Jugan; their functions are today restricted to customary life (adat). Similarly, as in Julah (Guermonprez 1998:54-55), they are not integrated into the krama desa but act separately, in cooperation with the paulun desa (the senior leaders of the krama desa). Whether these offices can be traced back to Ratu Subandar/Pesisir and Ratu Kamasan who seem to be the founders and the leaders of the sekehe gede, cannot be determined.

There is a ceremony organized by the krama desa that takes place in the Pura Jugan once a year in the sixth Balinese month (following the Hindu-Balinese calendar) when the representatives of all the clans as well as more than twenty-five temples (represented by symbols) assemble there. This ceremony is called kelaci, the official admission of newly married couples to the krama desa. It is surprising that this ceremony does not take place at the krama desa's homeplace, the Bale Agung in the Pura Desa. However, I understand it as a crossing-over of the two major village organizations (krama desa and sekehe gede) that serves to reinforce village solidarity. The couples who newly enter the krama desa have to pay a fee and, formerly, each had to sacrifice a calf (godeb). ${ }^{74}$ In contrast to - as far as I know - all other sacrifices of godel, the one killed at kelaci is not offered to the gods. The animal is butchered and its meat immediately allocated in portions to the members of the krama desa. This formal and communal celebration supplements the actual admission of individual couples to the krama desa that takes place immediately after marriage at the official monthly meeting in the village temple, Pura Desa, on the day of the "dead moon" (the moonless night).

Additionally, Pura Jugan is also concerned with individuals as members of the community; the stages of marriage and death have to be reported there. ${ }^{75}$ Moreover, individuals who have trespassed across norms (committing incest, bestiality, etc.) have to perform purification rituals in the course of which they have to report there, too, as well as to another closely related temple, the Pura Cungkub. Cungkub (or rather cungkup) literally means the roof over a Muslim grave or even the dome or upper part of a mosque; people in Sembiran translate the word simply as "building." 76 Once a year the unmarried young men (teruna) of the village had to construct a new fence starting at Pura Cungkub, passing by Pura Pendem,

\footnotetext{
${ }^{74}$ Since nowadays most of the inhabitants of Sembiran are rather poor, only one godel bought by the village is killed for all couples together.

${ }^{75}$ For a detailed description of the life cycle rituals see Riemenschneider and HauserSchäublin 2006.

${ }^{76}$ Whether Pura Cungkub was a special Islamic site of worship or even the grave of one or both of the prominent Islamic immigrants remains unclear. The same applies to Pura Pendem, pendem meaning "grave"; there are indications that support this interpretation of former Muslim sacred sites (Chambert-Loir 2002).
} 
and ending at Pura Jugan. The purpose of the fence was "to prevent animals [pigs and dogs?] from entering this area"; nowadays this fence is no longer built, though people speak about it as if they continue to build it. The two sites, today's Pura Jugan and Pura Cungkub, were (and partly still are) the major places where the villagers were regularly called to account for their behavior. Changes in their life status were acknowledged there.

There are other oral histories which seem to allude to specific socio-political processes that might have taken place in or around Sembiran (and Julah). They are difficult to locate in any historical era. Nevertheless I will briefly outline them because they contribute to the understanding of the fluctuation of socio-political processes to be discussed in this paragraph. These histories tell of a sovereign, called I Dewa Gede, who ruled over Sembiran and other villages but apparently did not live in the village. I Dewa Gede integrated between 20 and 30 villages into an overarching organization. He also issued laws and exercised control over artisans and workmen. Whoever wanted to carry on a trade or occupation had to ask for a permit first (and probably had to pay a tax). Those who did not conform to these regulations had to face punishment both in the material world (punished by men) as well as in the transcendental realm (punished by the gods). He assembled the villagers in the Pura Puseh and instructed them how to carry out proper rituals, what kind of ingredients had to be used, how to make offerings; he taught them songs, too. He requested all immigrants to follow the customs of Sembiran and to give up those they had brought with them.

I Dewa Gede is portrayed as an immigrant too (but definitely not of Islamic faith) who became the ruler not only over the village but a whole region; he also carried out reformations and innovations. In contrast to Ratu Subandar/Pesisir and Ratu Kamasan, he pleaded for conformity to the rules and practices he had set up. He did his best to keep off cultural change due to further interactions with people from outside. If I interpret this history correctly, I Dewa was a further cultural hero ${ }^{77}$ who integrated Sembiran into his domain. He created regular meetings and coordinated meeting days for all the villages throughout his domain. In this way he was able to attend all these meetings, if he wanted, without temporal overlap. It is to him that the building of a seven-tiered Pura Puseh shrine is attributed; the Pura Puseh was intended to replace or supplement the Pura Dulu and its function. Pura Puseh, as may be remembered, represents Sembiran more or less as the centre in the midst of extra-village relations which all shrines to both sides embody.

\footnotetext{
77 "Further" is not be understood in term of time sequences since it is impossible to determine to what extent this story mirrors a historical episode and if so, whether this was earlier or later than that of the Muslim immigrants outlined above.
} 
The reminiscence kept of another former regional ruler is that of I Gusti Agung Pahang. His memory has been kept alive due to the evil deeds he carried out. Moreover he is said to have lived in a place that belongs to Banjar Panggung, Sembiran, not too far away from Upit. At this site, still today called Pahang, people maintained that they had found tools and pottery sherds. I Gusti Agung Pahang was killed and the settlement levelled to the ground. ${ }^{78}$

Even the earliest colonial sources, those established by Dutch administrators, give evidence of the fact that Sembiran was then part of a kingdom. Liefrinck noted that in the mid 19 ${ }^{\text {th }}$ century Sembiran was integrated into the kingdom of Buleleng and had to pay taxes in kind (rice) and money to the king (1934:71-72). A substantial part of the best agricultural land (10.5 hectares) located near the coast was king's land (tanah tetaminyan anak agung) (Liefrinck 1924:384).

All such stories are indications that isolation and egalitarianism were not urcharacteristics of Sembiran - and Julah as well. There seem to have always existed a tension between egalitarian tendencies and those of ranking and stratification within these villages and beyond (see also Geertz and Geertz 1975:167). Today, the elders of both villages hold that people who immigrated to Sembiran or Julah over the past and looked for affiliation had to give up their title (if they had one) and to cut off their bonds to the village they came from. Julah tells the story of "perang kasta", a fight between members of different title-bearing groups who struggled over the social ranking and the way people should address each other, revealing subordination and domination. The conflict was solved by setting up the rule that the inhabitants were allowed to call each other only by the polite form of address of "jero".

Again, this story allows a new glimpse into the socio-political processes that took place in Sembiran and Julah; it shows that the inhabitants, mainly the members of the krama desa, shaped their polity themselves and were not subject to the actions of outsiders.

All these histories told in Sembiran show that its people are well aware of their past and the many changes their village, their political organization and their rituals practices have undergone. Active change and innovation are important cultural

\footnotetext{
78 Whether this Gusti Agung Pahang is the same as the one mentioned in the Babad Buleleng (Worsley 1972:61-69) is uncertain, but possible. According to the Babad Buleleng, Ki Gusti Agung Pahang lived in the first half of the $19^{\text {th }}$ century; he succeeded to the throne of Den Bukit. He ruled for only two years (1829-1831). After endless murdering, he was forced to flee and was later killed (Simpen 1989:25). The settlement he founded was leveled to the ground after he had been killed by the people he had tormented. The same fate, for reasons unknown, befell the settlements of Lebang and Pohontanduk, both up in the mountains on Sembiran and Julah territory.
} 
factors and at the core of their self-understanding and of the dynamic potential of the villagers and their culture - also with respect to their future.

\section{References}

Ardika, I Wayan

1991 Archaeological Research in Northeastern Bali, A Thesis Submitted for the Degree of Doctor of Philosophy at the Indonesian National University. Canberra: Australian National University.

Ardika, I Wayan; P. Bellwood; I Made Sutaba and Kade Citha Yuliati

1997 Sembiran and the First Indian Contacts with Bali: An Update. Antiquity 71: 193195.

Ardika, I Wayan and Ni Luh Sutjiati Beratha

1996 Perajin pada Masa Bali Kuno Abad IX-Xl, Vol. 1. Denpasar: Fakultas Sastra, Universitas Udayana.

Ardika, I Wayan and Ni Luh Sutjiati Beratha

1998 Perajin pada Masa Bali Kuno Abad IX-Xl, Vol. 2. Denpasar: Fakultas Sastra, Universitas Udayana.

Awig-Awig Desa Adat Sembiran

1988

Bagus, I Gusti Ngurah

1968 Clan dalam Hubungannya dengan Pola Menetap di Desa Sembiran. Denpasar.

Barth, Fredrik

1993 Balinese Worlds. Chicago, London: The University of Chicago Press.

Brandes, J.L.A.

1890 De koperen platen van Sembiran (Boeleleng, Bali): Oorkonden in het oudJavaansch en het oud-Balineesch. Tijdschrift voor Indische Taal-, Land- en Volkenkunde XXXIII: 16-56. Batavia: Albrecht \& Rutche.

Budiastra, P.

1975 Rajapurana Pura Ulun Danu Batur, Kintamani, Bangli, Vol. 1. Denpasar: Museum Bali.

1979 Rajapurana Pura Ulun Danu Batur, Kintamani, Bangli, Vol. 2. Denpasar: Museum Bali.

Bundschu, Inge

1985 Probleme der agraren Grundbesitzverfassung auf Bali. Hamburg: Weihert Druck $\mathrm{GmbH}$.

1994 Agrarverfassungen und Agrarentwicklung in Indonesien. Studien zur Agrarökologie. Hamburg: Kovač. 
Chambert-Loir, Henri

2002 Saints and Ancestors: The Cult of Muslim Saints in Java: In: Henri ChambertLoir and A. Reid (eds.): The Potent Dead: Ancestors, Saints and Heroes in Contemporary Indonesia; pp. 132-140. Crows Nest, Honolulu: Hallen and Unwin and University of Hawai'i Press.

Christie, Jan Wisseman

1994 Wanua, thani, paraduwan: the "Disintegrating" Village in Early Java?. In: Marschall, Wolfgang (ed.): Texts from the Islands. Oral and Written Traditions of Indonesia and the Malay World. Ethnologica Bernensia, Vol. 4: 27-42. Bern: Institute of Ethnology.

Couteau, Jean

1999 Bali et l'islam: 1. Rencontre historique. Archipel 58: 159-188.

2000 Bali et l'islam: 2. Coexistence et perspectives contemporaire. Archipel 20: 45-64.

Covarrubias, Miguel

1986 (1937) Island of Bali. London, New York: KPI.

Français-Simburger, Angela

1998 'Politics of the Center' in Bali's Cultural Periphery: Transformations of Power in an Old-Balinese 'Village Mandala'. Ann Arbor: UMI.

Friedman, Jonathan

1998 System, Structure, and Contradiction. The Evolution of Asiatic Social Formation. Walnut Creek, London, New Delhi: Altamira.

Geertz, Hildred and Clifford Geertz

1975 Kinship in Bali. Chicago: The University of Chicago Press.

Ginarsa, K.

1979 Pura Bukit Tunggal dalam Prasasti. Singaraja: Balai Penelitian Bahasa.

Goris, R.

1954 Prasasti Bali. Lembaga Bahasa dan Budaya. Fakultas Sastra dan Filsafat, Universitas Indonesia. Bandung: Masa Baru.

Goris, R. and N. Poeger

1965 Prasasti Sembiran, Djulah. Denpasar: Unpublished Report.

Graves, Elizabeth and Charnvit Kaset-siri

1969 A Nineteenth-Century Siamese Account of Bali with Introduction and Notes. Indonesia 7 (April): 77-122.

Guermonprez, Jean-François

1980 L'organisation villageoise à Bali. Asie du Sud-Est et Monde Insulindien XI. (ASEMI) 143: 37-54.

1987 Les Pandé de Bali. La formation d'une «caste» et la valeur d'un titre. Paris: Ecole Française d'Extrême-Orient.

1998 Julah, un village 'vieux balinais', L'Homme 147: 51-79.

2001 Religion balinaise dans le miroir de l'hindouisme. Bulletin de l' École Française d'Extrême-Orient 88: 271-293. 
Hauser-Schäublin, Brigitta

2003a Raum, Ritual und Gesellschaft. Religiöse Zentren und sozio-religiöse Verdichtungen im Ritual. In: Hauser-Schäublin, B. und M. Dickhardt (Hg.): Kulturelle Räume - räumliche Kultur. Zur Neubestimmung des Verhältnisses zweier fundamentaler Kategorien menschlicher Praxis. Göttinger Studien zur Ethnologie, Bd. 10: 43-88. Münster [u. a.]: LIT.

2003b The Pre-colonial Balinese State Reconsidered. A Critical Evaluation of Theories on the Relationship between Irrigation, the State, and Ritual. Current Anthropology 44, 2: 153-182.

2004a The Politics of Sacred Space. Conceptual Models of Space and Socio-Political Transformations in Bali. Bijdragen tot de Taal-, Land- en Volkenkunde 161, 2/3: 283-314.

2004b "Bali Aga" and Islam. Ethnicity, Ritual Practice, and the "Old-Balinese" as an Anthropological Construct. Indonesia 44: 27-55.

2004c Austronesian Aboriginality or the Ritual Organization of the State? A Controversy on the Political Dimension of Temple Networks in Early Bali. History and Anthropology 15, 4: 317-344.

2005 Temple and King: Resource, Management, Rituals and Redistribution in Early Bali. The Journal of the Royal Anthropological Institute 11: 747-771.

2007 Rivalling Rituals, Challenged Identities: Accusations of Ritual Mistakes as an Expression of Power Struggles in Bali (Indonesia). In: Hüsken, Ute (ed.): When Rituals go Wrong: Ritual Dynamics, Mistakes and Failure, pp. 245-271. Leiden, Boston: Brill.

2008 Ritual, Pilgrimage and the Reconfiguration of the State. Sacred Journeys in the Political Landscape of Bali (Indonesia). In: Gengnagel, Jörg, Horstmann, Monika und Gerald Schwedler (Hg.): Prozessionen, Wallfahrten, Aufmärsche. Bewegungen zwischen Religion und Politik in Europa und Asien seit dem Mittelalter. Bd. 4 Menschen und Kulturen: 288-311. Wien: Böhlau.

Korn, V.E.

1984 [1933] The Village Republic of Tenganan Pegeringsingan. In: Bali. Studies in Life, Thought, and Ritual; pp. 301-368. Dordrecht [u.a.]: Foris Publ.

Lansing, John Stephen

1977 Rama's Kingdoms: Social Supportive Mechanisms for the Arts in Bali. Ann Arbor: UMI.

Lansing, John Stephen et al.

2004 An Indian Trader in Ancient Bali? Antiquity 78, 300: 287-293.

Liefrinck, F.A.

1924 (1920) Grondenrecht in Boeleleng In: Adatrechtbundels XXIII. Java en Bali, pp. 381-384. 'S-Gravenhage: Martinus Nijhoff.

1927 Bali en Lombok. Amsterdam: J.H. de Bussy.

1934 (1882-1889) Bali en Lombok. Noord-Balische Desa-Monographieen. Adatrechtbundels XXXVII. 'S-Gravenhage: Martinus Nijhoff. 
Pangacin-Acin Ida Bhatara

1979 In: Budiastra, P.: Rajapurana Pura Ulun Danu Batur, Kintamani, Bangli, Vol. 2: 191-249. Denpasar: Museum Bali.

Pratekaning Usana Siwasasana

1979 In: Budiastra, P.: Rajapurana Pura Ulun Danu Batur, Kintamani, Bangli, Vol. 2 : pp.137-190. Denpasar: Museum Bali.

Proudfoot, Ian

2007 In Search of Lost Time. Javanese and Balinese Understandings of the Indic Calendar. Bijdragen tot de Taal, Land- en Volkenkunde 163, 1: 86-112.

Reuter, Thomas

2002 The House of Our Ancestors. Precedence and Dualism in Highland Balinese Society. Leiden: KITLV.

Riemenschneider, Christian und Brigitta Hauser-Schäublin

2006 „.....Yang Hidup di sini, Yang Mati di sana“: Upacara Lingkaran Hidup di Desa Sembiran, Bali (Indonesia). Göttinger Studien zur Ethnologie, Bd. 15. Münster: LIT-Verlag.

Simpen, W.

1989 Babad Kerajaan Buleleng. Denpasar: Cempaka.

Southall, Aidan

1956 Alur Society: A Study in Process and Types of Domination. Cambridge: Cambridge University Press.

Sutaba, I Made

1985 (1976) Megalithic Traditions in Sembiran, North Bali. Jakarta: PT Guruh Kemarau Sakti.

Swellengrebel, J.L.

1984 'Introduction'. In: Bali. Studies in Life, Thought, and Ritual; pp. 1-76. Dordrecht [u.a.]: Foris.

Wirz, Paul

1928 Der Totenkult auf Bali. Stuttgart: Strecker und Schröder.

Wardka, I Wayan

1987 Tawan Karang. Satu Kasus Belli di Bali: Laporan Penelitian. Jurusan Arkeologi Fakultas Sastra. Denpasar: Universitas Udayana.

Worsley, P.J.

1972 The Babad Buleleng. A Balinese Dynastic Genealogy. Biblioteca Indonesia 8. The Hague: Martinus Nijhoff. 


\title{
The Textiles of Sembiran
}

\author{
Marie-Louise Nabholz-Kartaschoff
}

\section{Introduction}

Some museums and private collectors in Europe, the United States, and Australia are proud owners of so-called "kain Sembiran", archaic-looking, striped cotton wrappers with a predominantly patterned centre. This part shows geometrical or stylised floral patterns which are executed with a thick gold thread in supplementary weft technique, and - seldom - interspersed with simple weft ikat stripes. This was a good reason for thoroughly investigations of this category of textiles. ${ }^{1}$ As I will show, genuine Sembiran cloth turned out to be of a completely different style than hitherto labelled "kain Sembiran".

\footnotetext{
${ }^{1}$ As I could not carry out fieldwork on this subject myself, I am deeply indebted to Brigitta HauserSchäublin who encouraged me to undertake this research, and who, during many stays in Sembiran between 1997 and 2006, unremittingly discussed my many questions with weavers, priests and other people in and outside the village. Her main informants in Sembiran were Mangku I Nyoman Sutarmi and the weavers Ni Wayan Landri and Ni Ketut Sri Ngentek. Her valuable data were enriched by photographs of hers and of her husband, Jörg Hauser. She also permitted access to the large photo documentation and fieldnotes in the archives of the University of Göttingen, collected by Christa Schot in 2001 and Christian Riemenschneider in 2003.

I am grateful to many colleagues and other persons who generously participated in discussions, inspired me with new ideas, constructively criticized my work, and allowed me access to comparative material in museum and private collections: Georges Breguet, Francine Brinkgreve, Diana Collins, Marie-Hélène Guelton, Linda Hanssen, Rens Heringa, Robert Holmgren, Norman Indictor, Susi Johnston, Alan Kennedy, Brigitte Majlis, Gerry Masteller, Michael Peter, Claudine Salmon, Heinz Schneider, John Summerfield, Anita Spertus, David Stuart-Fox.
} 
According to Nevermann (1938:18-19), the very first records on cotton weaving in Bali and Java are to be found in the Annals of the T'ang Dynasty (618-907). During this period of China's expansionist foreign policy, a Balinese prince would have sent cotton cloths along with sandalwood and ivory as tributes to the Emperor of China. Nevermann deduces that these cotton textiles would have been produced in Bali itself, and - as gifts to an imperial authority - would testify to an already quite developed art of weaving. The same author also states from the book Hsing-ch'a Shêng-lan by the seafarer Fei Hsin (1486), that Javanese traders imported cotton "Java cloth" to Samudra and Pahang in the kingdom of Srivijaya, which seemed to have been woven in Java and Bali (1938:19).

Stuart-Fox systematically searched through ancient Balinese inscriptions from the late 9th to the 14th century for references regarding textile materials and crafts. ${ }^{2}$ These inscriptions concern coastal villages such as Julah, Pacung, Tejakula, Sembiran, or the villages of Sukawana and Kintamani in the central mountain area. Raw cotton (kapas) and cotton yarn (benang) are explicitly mentioned as local products (Stuart-Fox 1993:86). Clear regulations granted the right to trade raw cotton to certain villages, to spin and weave cotton to other villages, while still others were explicitly forbidden to do so (Stuart-Fox 1993:87). The author concludes: "The fact that the great majority of references to cotton and dye-stuffs concern north coast and central mountain villages may indicate that such production was restricted to these areas", and "The inscriptions indicate a well-organized and well-regulated trade network linking north coast villages with mountain villages in the Batur area", and he finally states that Balinese textile products, particularly cloth, played an important role in inter-island trade (Stuart-Fox 1993:91).

Various sources from the 16th to 19 th centuries confirm the importance of Balinese cotton products in this trade; let us quote a few examples:

According to Dutch reports of Javanese maritime trade at the beginning of the 17th century, merchants from the important port of Tuban exchanged pepper in Bali against pieces of simple cotton cloth, woven there in quantity and in "various colours and workings, which they are very artful in and supply the surrounding islands with", and which were particularly in demand in the Moluccas. ${ }^{3}$

William Marsden, an employee of the East India Company in Sumatra from 1771 to 1779 , gives a detailed list of foreign textiles in circulation in wealthy Sumatra which includes not only different cloths from India, Makassar and Java, but also a variety of sarongs (skirt-lengths) from Bali (Guy 1998:68). Even Sir Thomas Stamford Raffles mentions in his "History of Java" (1817 I:204) under the headline "Exports and Imports of Java" that "cloths are also sometimes imported

\footnotetext{
${ }^{2}$ These royal edicts bearing dates and names of kings contain pieces of information on cotton production and textile manufacture in connection with the imposition and raising of taxes and tributes, as well as trade regulations for certain North Balinese village communities to the royal centers of power, on traders of different origins along the North Balinese coast and on protection from piracy (see also Hauser-Schäublin 2004:33).

${ }^{3}$ Schrieke $1955: 20-21,32$ and notes 80 to 82 .
} 
from Bali" and adds that "the island produces cotton of the most excellent quality and in great abundance" (1817 II:ccxxxiv). In 1830, a Frenchman, Comte C.S.W. de Hogendorp, reports in his «Coup d'oeil sur l'Ile de Java et les autres possessions hollandaises dans l'Archipel des Indes» that raw cotton from Bali is highly estimated, and exported to Java (Salmon 2005:20). Under Dutch rule, Pabejan Buleleng, Sangsit and other important seaports on the North Balinese littoral were bustling centers of an international and inter-insular business network. In a list of imported goods dated 1873, we find foreign and domestic textiles from neighbouring islands, as well as raw silk, gold leaf and gold thread, whilst the corresponding table of export goods lists indigenous cloth and a relatively small amount of raw cotton (Van Eck 1880:20-21). Van Eck adds that Bali had previously been famous for red yarn, sarongs and selendangs woven locally, and exported them in huge amounts to other places. Javanese traders bought them under the label "Caeyn-baly" (cloths from Bali). Their manufacture, however, had steadily decreased due to the import of foreign goods; production continued on a low scale and for local consumption only (Van Eck 1880:22-23), and by the beginning of the 20th century, textiles were no longer exported. Only foreign visitors would here and there acquire such indigenous fabrics (Fraser 1908: 333).

The village of Sembiran has been discussed extensively by several authors. ${ }^{4}$ In the frame of this article, we only summarize a few topics which are relevant in connection with the manufacture of textiles, their use by the people of Sembiran and in other places, and in connection with possible outside influence. While most anthropologists have labeled the village as a classical "Bali Aga" community, Hauser-Schäublin has pointed out, based on "an analysis of oral histories, temples and rituals as well as of its social organization", that "Sembiran has been a village where people of differing origins and with different ritual practices met, producing a culture that displays corresponding traits, Islamic elements being among the most prominent" (2004:28-29).

In the course of this study, we shall discover that the particular textile culture of Sembiran was not one restricted to an isolated Bali Aga village, even if it shows a few traits in common with the most renowned Bali Aga village, Tenganan Pageringsingan in East Bali. For centuries, however, Sembiran has been deeply embedded in a wide inland and even transmaritime trade network, due to its location near the North Balinese seaports. It also has played a role as part of a system of ritual connections with important temples in the areas of Batur and Sukawana in the central mountain region. ${ }^{5}$ According to local oral histories, the population of Sembiran is a conglomerate of so-called "original" inhabitants (Bali Mula), still

\footnotetext{
${ }^{4}$ See e.g. Hauser-Schäublin 2004; Riemenschneider 2004; Riemenschneider and HauserSchäublin 2006; see also Hauser-Schäublin this volume.

${ }^{5}$ See e.g. Reuter 2002:51, 52, 107, 187; Hauser-Schäublin 2004; Hauser-Schäublin 2005: 761.
} 
speaking their own language, mixed with immigrants who migrated to Sembiran in a number of "waves" from outside Bali going back to pre-colonial times; most of these immigrants are associated with Islam (Hauser-Schäublin 2004:54). Among them are descendants of the Sasak people who arrived in the middle of the last century from Lombok and East Bali to Sembiran and the neighbouring village of Julah, where they still live in a separate ward (dusun). ${ }^{6}$ It is therefore only to be expected that the textile culture of Sembiran has undergone a lot of external influences, and that connections to Lombok are of particular relevance to our subject. ${ }^{7}$

In spite of its label as a "Bali Aga" village, Sembiran today is a progressive community. Its inhabitants are ready to throw overboard old customs and traditions, and to adopt and integrate innovations. Recollection and consciousness of the past play a very minor role, are not cultivated and do not appear to have any particular value. Even older informants often lack memory of certain subjects and seem to be surprised that past times should give rise to so much interest. ${ }^{8}$

On the other hand, it is surprising to see to what extent importance is still attached to a few traditional forms of garb for certain special occasions and social groups, and how much these simple indigenous, hand-woven cloths have become a sign of distinct identity to the members of the village community of Sembiran (p.82-84).

\section{The Manufacture of Textiles}

As mentioned above, firm written testimony of cotton cultivation and cotton yarn production in North Bali go back as far as the $10^{\text {th }}$ century AD (Stuart-Fox 1993:86). In colonial times, cultivation of different species of cotton ${ }^{9}$ was widely spread in Java, Sumatra (Palembang), as well as on Lombok and Bali. In Java the production was strongly promoted by the Dutch government with a view to export possibilities (Jasper en Pirngadie 1912:11-12, 20; Heyne 1927:1039-1046).

\footnotetext{
${ }^{6}$ Hauser-Schäublin 2004: note 61. Part of Lombok had been ruled by the Balinese kingdom of Karangasem between 1692 and 1894. At the beginning of the 20th century, 4.000 Sasak immigrants lived in Karangasem (Korn 1932:65); after the eruption of the volcano Gunung Agung in 1963, many Sasak and Balinese escaped from there to North Bali.

${ }^{7}$ Apart from Sasak from Lombok, there exist other small communities of Muslims that immigrated during centuries from Makassar in South Sulawesi, from Java and Madura, and from Sumbawa. They had settled down in Jembrana, Klungkung, Badung and in Buleleng (Pagajaman, Tegallingah, Banjar Jawa, Pabean, Kalibukbuk, Temukus, and Watu Gunung). In Bali, they are generally called Bali Slam or Bali Slem. This term refers to types of ritual practices that differ from Hindu-Balinese norms. They frequently married Balinese women, in spite of royal decrees restricting marriage between Muslims and other Balinese subjects (Vickers 1987:39, 43-44, 53, and note 51, following Korn 1932:67).

${ }^{8}$ Personal communication from Brigitta Hauser-Schäublin, 2006.

${ }^{9}$ Nevermann (1938:31-39) enumerates many different species of Gossypium cultivated in Indonesia, and gives dozens of indigenous names; Jasper en Pirngadie (1912:13) mention a kind called kapas huma besar as being typical of Bali.
} 
In his short report on Bali, Raffles confirms that the island of Bali "produces cotton of the most excellent quality and in great abundance" and mentions cotton yarn and coarse cloths among the main export goods (Raffles 1817 II:ccxxxiv).

Apart from the villages of Julah and Pacung, it was particularly Sembiran that had been famous for cotton cultivation (Hauser-Schäublin 2004:38). During World War II, the traditional kapas Bali ${ }^{10}$ had been replaced by the Japanese by a new species called kapas tuan, which developed quicker and needed less care, but under the present climatic conditions - too hot, too dry - both of these had to be abandoned. However, the use of handspun cotton yarn is also essential in a number of rituals. For this purpose, people buy raw cotton or hand-spun cotton yarn directly from personally-known producers in other villages, in particular in Julah, or they plant in their backyards small quantities of a new species, kapas lilit.

This variety (the botanical name of which we could not yet determine) has long, curly staple fibres, appropriate for industrial spinning (the Indonesian word lilit means "to turn", "to twist"); in Java, its cultivation for spinning mills has been highly promoted by the government since the $1970 \mathrm{~s}^{11}$; it is, however, not suitable for the production of hand-spun yarn or for hand-weaving. ${ }^{12}$

In the past, all steps from planting and processing the cotton up to spinning and weaving had been carried out by women within their family. There were no specialists for particular tasks, except that some women were better weavers than others.

The raw cotton was cleaned from its seeds with the help of a cotton gin (pemipisan), loosened with the help of a bow with a cord (penjetetan), then spun into yarn on a hand-spinning wheel (jantra), and wound into skeins on a skein-winder (mutuhan). All these tools are similar to the ones found all over Bali. However, as late as the beginning of the $20^{\text {th }}$ century, they still did not use the jantra for winding the weft thread on a spool-stick, as elsewhere in Bali, but used a very special shape of tool, a wooden fly-wheel fitted on to the base of the spool-stick. This archaic implement is also known from Tenganan in East Bali ${ }^{13}$, from Kintamani in the central mountain region ${ }^{14}$, as well as from Cempaka near Bubunan and from Sasak people in Lombok ${ }^{15}$; in all these places, it bears the same name, keper.

The great significance of cotton cultivation in the past is confirmed by a still existing ritual relationship between Sembiran and the temple of Batur (Pura Ulun Danu Batur), which was a major tax- and tribute-collecting institution for North

\footnotetext{
${ }^{10}$ According to Nevermann (1938:35) kapas bali is the Javanised name for Gossypium indicum Lam var. arborescens.

${ }^{11}$ Personal communication from Rens Heringa, 2006.

${ }^{12}$ Personal communication from the Sembiran weaver Ni Wayan Landri to Brigitta HauserSchäublin, 2006.

${ }^{13}$ Museum der Kulturen Basel no. IIc 7460; see Bühler 1943:206 and fig. 165.

${ }^{14}$ RMV Leiden no. 2407-153, acquired in 1939.

${ }^{15}$ Bolland and Polak 1971:154-55, and fig.5; Bolland 1971:176. Note, that Tenganan, Cempaka as well as Sembiran were considered to be genuine Bali Aga villages at the time of Bolland's research.
} 
and Central Bali. As one of Batur's traditional temple-supporting villages, pasyan, Sembiran is still expected to bring certain tributes when on pilgrimage to the Batur Temple on the occasion of a huge temple ritual of the last Balinese month. Some time ahead of the ceremony, each village receives an official invitation written on palm leaf, containing a list of offerings and goods to be brought along. The nature of these kinds of taxes depends on the villages' economy and their products.

For Sembiran, this means bringing among other items unprocessed raw cotton to be used for rituals (Photo 1). ${ }^{16}$

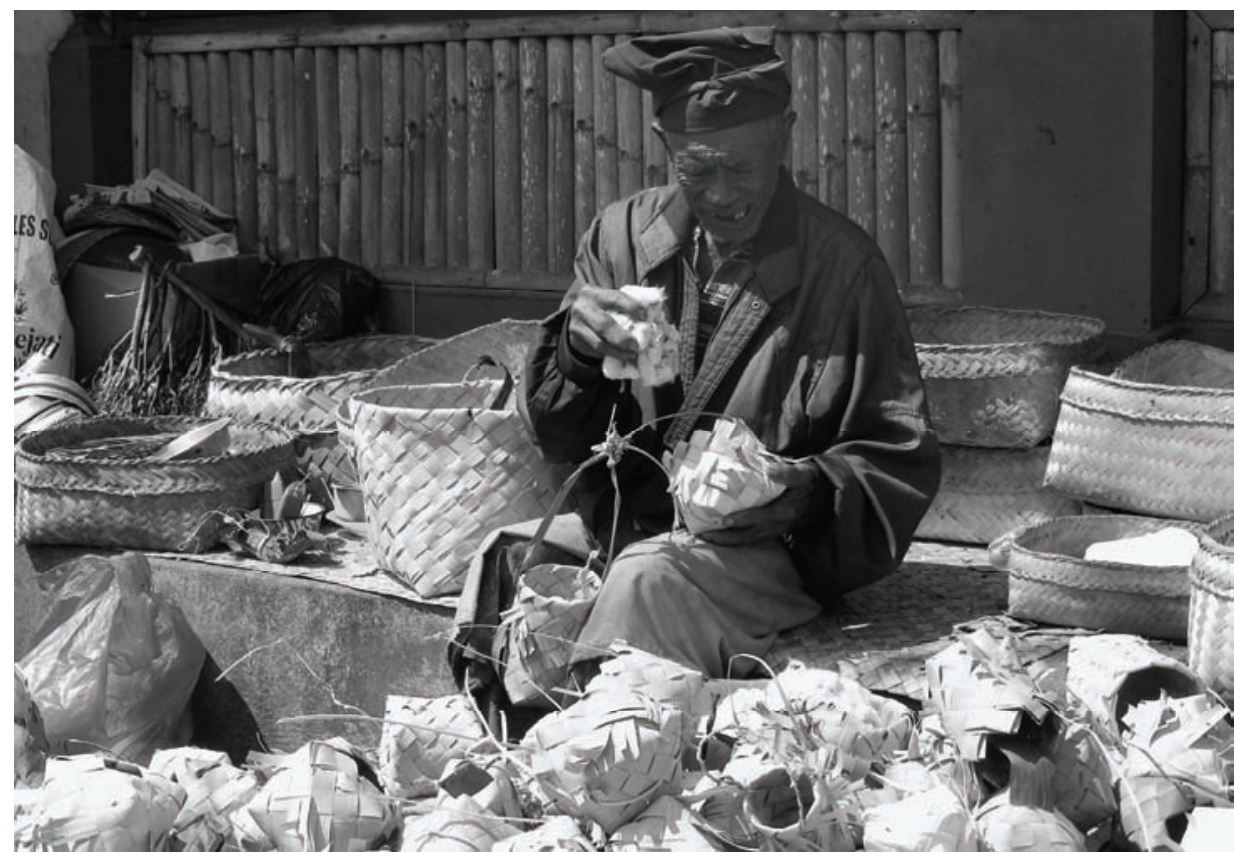

Photo 1: Raw kapas lilit cotton, offered as tribute to the Batur Temple by villagers of Sembiran.

Photo: Jörg Hauser 2006.

The so-called cagcag loom used by Sembiran weavers is of a type widespread in the traditional home-industry all over Bali for the manufacture of plain, striped and checked cotton and silk cloth, for weft ikat (endek) and for songket textiles with supplementary weft designs. It is a backstrap loom with a long, one-layered discontinuous warp wound around a plank-like warp roller (pandalan). This plank is mounted in the slots of two massive fork-shaped slanting posts which are fixed in

\footnotetext{
${ }_{16}$ Personal communication from Brigitta Hauser-Schäublin, 2006; see also Hauser-
} Schäublin 2005:759; Reuter 2002:107. 
a heavy wooden construction (tatakan cagcag). The warp ends nearest the weaver are attached to a bipartite breast or cloth roller (apitan), fixed to her back with a rather broad wooden yoke (por). A heavy horizontal post placed on the ground under the warp roller facilitates the bracing of the feet when the weaver leans back to give greater tension to the warp. The ground sheds for the foundation plain weave are opened by means of a shed stick (mumbungan) and one rod with heddles (jeriring). There is a reed (serat) with the twin function as warp-spacer and for beating in the weft threads in combination with a heavy long weaving sword (belida), which can be temporarily deposited on a support (rorogan) made out of a thick bamboo tube. ${ }^{17}$ The combined action of a reed and a sword allows a much denser beating-up the weft threads. The weft spool (peleting) is fixed in a quiver (tundak) made from a hollow bamboo tube, open and split into four or more tongues at one end. ${ }^{18}$

Only cloths in simple tabby weave and of limited width can be woven on this loom. Supplementary weft patterns would need much more sophisticated equipment with additional hand-operated pattern heddle rods, and cloths of a bigger width are always composed of two webs sewn together. In Photo 2, Ni Wayan Landri is seen weaving the middle section of a woman's shoulder-cloth with blue and white stripes which is usually 45 to $50 \mathrm{~cm}$ wide, and which takes her five to six days of work. The price for such a shoulder-cloth amounted to about 30.000 Rs in 1998. ${ }^{19}$

While the loom itself has not undergone any changes since the 1920s (Photo $3)$, it is possible that in earlier times a less developed device than the weft spool in a quiver was used in Sembiran for introducing the weft.

In her analysis of oral histories, Hauser-Schäublin (2004:38 and note 62) pointed to the fact that Muslim immigrants were innovators of different kinds: "One of the stories deals with a technological innovation a Muslim man - a "black dog" - brought to the village. [...] One day a young woman - the story calls her the daughter of a pig, alluding to the fact she was a descendent of an indigenous couple whose ritual practices included the ritual offering of pigs and pork - was tired from the inefficiency of her weaving gear because the yarn frequently dropped from her weft stick (peleting). She swore that whoever brought a device that prevented the yarn from dropping she would serve for the rest of her life. It was a

\footnotetext{
17 The weaver in Sembiran called it a kulkul.

18 A similar loom from Sembiran in the Wereldmuseum Rotterdam (no. 25998) acquired from L.C. Heyting in 1924 was mentioned by Bolland (1971:173). The construction is made of aren palm wood and bamboo. I checked the lengths of the main parts: warp roller $105 \mathrm{~cm}$, breast roller $103 \mathrm{~cm}$, heddle rod $104 \mathrm{~cm}$, shed stick $103 \mathrm{~cm}$, reed $65 \mathrm{~cm}$ ); these dimensions would never allow the weaving of large widths; the half-finished cloth on the loom is only $57 \mathrm{~cm}$ wide. Also, the reed has relatively wide openings (65 per $10 \mathrm{~cm}$ only); thus it was only suitable for weaving rather coarse cloth of hand-spun cotton, while finer cloth would require at least between 100 and 150 openings.

${ }^{19}$ Personal communication from Brigitta Hauser-Schäublin, 1998.
} 
black dog who brought her such an ingenious device, a quiver (tanduk) consisting of a bamboo tube that prevented the yarn from dropping from the weft stick. So she gave him food and let him in her house at night." I had suggested that this story might refer to a possible technical change from an early type of weft stick without a quiver which is still used in eastern islands of East Indonesia (e.g. Timor, Rote, Savu, etc.), to the weft stick in a quiver mentioned above, which is used throughout Bali, in Java and Sumatra (Batak), and on Sumba, as well.

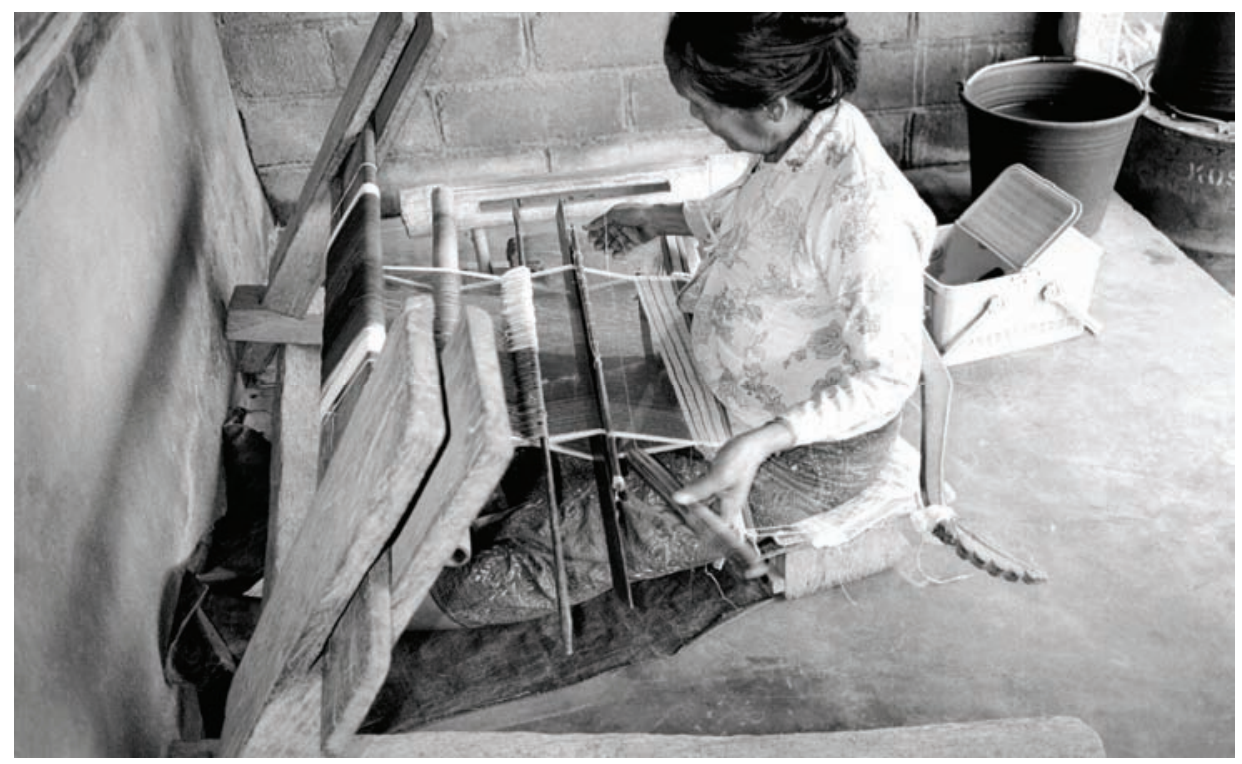

Photo 2: Ni Wayan Landri weaving a shoulder-cloth with red, yellow and white end stripes. Photo: Brigitta Hauser-Schäublin 1999.

This innovation could have accelerated the weaving process, as the new device would allow a quicker and more regular unwinding of the weft. The dropping of the yarn from the weaver's weft stick would just be a metaphor for the fact that a new device can be manipulated better and more efficiently. The question, however, as to when such a possible change could have taken place remains unanswered.

The dominant colour met within Sembiran is blue in different shades, mainly dark hues. Yellow and red stripes decorate the shoulder-cloths of women. 


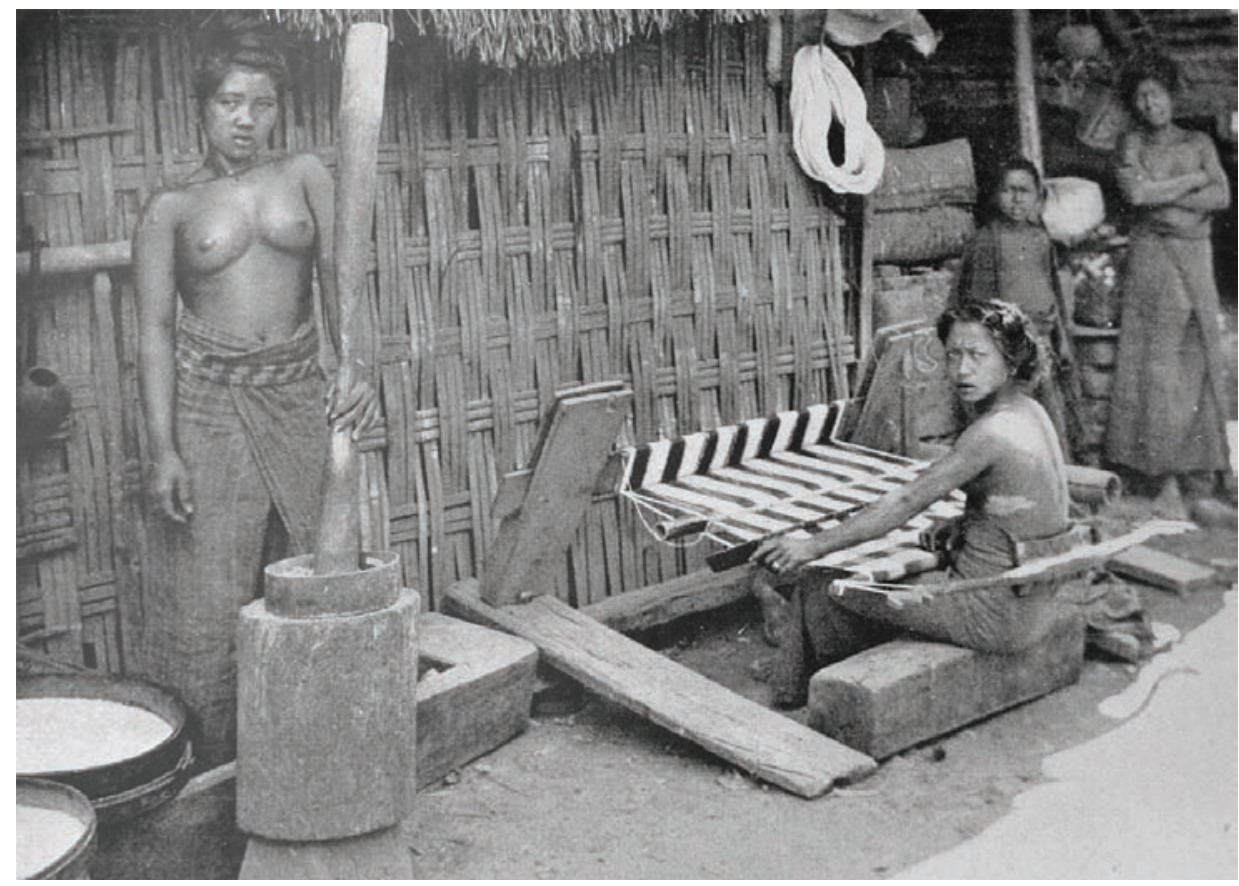

Photo 3: Women in Sembiran. The weaver is manufacturing a type of saput poleng worn today by bridgerooms, and all women are wearing checked hip-clothes which still form part of the present-day ceremonial daha costume. Photo: Controleur L.C. Heyting 1924; Collection Wereldmuseum Rotterdam, inv.no. 910128.

As synthetic colours were introduced in North Bali as early as the beginning of the $20^{\text {th }}$ century (Fraser 1908:326) ${ }^{20}$, practically no recollections of traditional dyeing with natural dyestuffs could be obtained from the weavers of Sembiran. They only remembered indigo as having been used for dyeing blue and leaves from an unknown bush (daun sugih) for green. Apparently, the village of Tejakula was specialized in indigo dyeing. ${ }^{21}$

We can only conjecture from information on dyeing found in ancient sources and from other places in Bali what dyestuffs might have been used in Sembiran in former times, namely indigo, mengkudu and turmeric or, possibly, safflower.

According to Stuart-Fox (1993:87), the oldest inscription (Sukawana 883 A.D.) mentions dyeing with indigo and with Morinda citrifolia in mountain villages: "In

\footnotetext{
${ }^{20}$ As early as 1908, Dutch administrative officials in Buleleng had been bewailing the loss of quality in endek materials when they were dyed with gaudy aniline dyes (Hauser-

Schäublin, Nabholz-Kartaschoff and Ramseyer 1991:21).

${ }^{21}$ Personal communication from Brigitta Hauser-Schäublin, 1998.
} 
north Bali, until at least the late 19th century, indigo was still grown as a secondary crop on rice land. Various ritual restrictions were attached to indigo production and dyeing." (Stuart-Fox 1993:88). Dyeing red, purple and reddish brown shades is achieved with mengkudu, the bark of Morinda citrifolia. The dyeing process is very complicated, as it needs pretreatments with oil and mordants, and is extremely time-consuming, repeated immersions in the dye-bath being required. Red-dyeing with Morinda was widely practised all over Indonesia Jasper en Pirngadie 1912: 61-69). In Bali it is still used nowadays in the village of Tenganan Pageringsingan in Karangasem, where it is called sunti.

Safflower (Carthamus tinctoria), or kasumba, for dyeing yellow or orange appears in the inscription of Bwahan, dated 995, and in many later inscriptions, such as for instance from Sembiran (A.D. 1016, 351 Sembiran A III) in connection with the exemption from taxation for the village of Julah. Its cultivation in the mountain regions continued up to the late 19 ${ }^{\text {th }}$ century (Stuart-Fox 1993:89). Whether safflower was really used for dyeing in Bali, and particularly in Sembiran, remains uncertain; it is locally planted turmeric (kunyit) that was preferred for this purpose as elsewhere in Indonesia (Fraser 1908:326; Bühler 1948:2489).

Lac dye, which very rarely appears in connection with textiles used in Sembiran, was an imported dye-stuff (p.94-95).

As mentioned above, imported synthetic dyes had begun to take over in North Bali at least as early as the beginning of the $20^{\text {th }}$ century. By the 1930 s, they had driven out traditional dyestuffs even in such remote places as Nusa Penida, where sunti, kunyit and indigo had been used before (Hauser-Schäublin, NabholzKartaschoff and Ramseyer 1991:99). This development is also confirmed for Java, Sumatra, and the coastal regions of Borneo by Jasper en Pirngadie (1912:73$74,77)$.

I came across only few examples of really old products that had originated with certainty from Sembiran:

- a complete set of clothing for a bridal couple (note 37),

- a cotton selendang (local name according to the collector blanja) with a white and indigo blue check design, and broader indigo blue and red stripes at one end (the other end is missing). It was acquired from Controleur L.C. Heyting by the Rotterdam Wereldmuseum in 1924 (no. 25994),

- a small man's jacket with a chequered dark blue and white poleng design (baju poleng) in the same collection, the use of which was unknown to present-day weavers - "one should have asked generations before us", was their comment - and - a badly damaged fragment, possibly of a cotton selendang, with dark indigo blue stripes on a white ground in the collection of Robert Holmgren and Anita Spertus (IA-276) which the owners attribute to the early 19th century, possibly to the $18^{\text {th }}$. Some of the older shoulder and hip cloths worn today by unmarried girls and women at festivals of the daha group and weddings may go back to the first half of 
the $20^{\text {th }}$ century, as they are not in every-day use but are passed down within the families.

At present, only two elderly weavers produce the cotton cloths used for ceremonial purposes. Ni Wayan Landri, for example, is still able to manufacture ritual women's shoulder- and hip-cloths and men's hip-cloths and saput poleng (Photo 10). On order, she also may weave white and blue checked hip-cloths for the priests of Sukawana (Photo 12).

Usually, they do not process hand-spun thread any longer - cultivating cotton and spinning have completely stopped - but instead buy industrially-spun, undyed yarn in the market. Only for the pattern stripes in women's shoulder-cloths is predyed yarn purchased. They dye the yarn for the dark parts - which previously used to be indigo-dyed - with a black, synthetic dyestuff of Indonesian or Chinese origin (brand: WANTEX). As it fades quickly, it easily turns into a grey or greybluish shade after some time. Sometimes, cloths that have become faded and ugly are re-dyed. ${ }^{22}$

In 2001, the government tried to promote a project for the revival of weaving traditions in Sembiran. Several women who still had some experience in weaving were to be trained under the guidance of the expert weaver Ni Wayan Landri. The first difficulty they met was to acquire appropriate yarn. There were in fact coarser and finer qualities on the market of Singaraja; hand-spun Balinese yarn, however, was hardly available. They finally found three skeins, and started dyeing, winding and weaving on Ni Wayan Landri's equipment. The dyestuffs were synthetic ones, but they planned to return to traditional vegetable ones. ${ }^{23}$ Five years later, the project to stimulate home-industry in the village failed due to lack of potential customers for woven products of this type. ${ }^{24}$

\section{The Use of Textiles Manufactured in Sembiran}

The village of Sembiran is organized in different ritual and social associations among which is the association of married couples (kerama desa), the association of unmarried men (teruna), and the association of unmarried girls (daha bunga) and women (daha tua). ${ }^{25}$ The eldest girl of each family becomes a member after having finished school; if she gets married, or leaves the village, the sister next to her in age will join the organization. The daha hold regular gatherings (sangkapan) in the Pura Bale Agung (Photo 4) at fixed dates (on Buda Wage days, six times a Balinese

\footnotetext{
22 Personal communication from Rens Heringa, 2006. Recently, she was still able to acquire in Sembiran a shoulder-cloth woven of hand-spun yarn. It probably had been woven some years ago, but is dyed with synthetic dyes.

${ }^{23}$ Fieldnotes Christa Schot, 2001.

${ }^{24}$ Personal communication from Brigitta Hauser-Schäublin, 2006.

${ }^{25}$ Hauser-Schäublin 2004:48.
} 
year of 210 days, or every 35 days respectively), and on Galungan and Kuningan, the most important festivals of the Balinese calendar. ${ }^{26}$

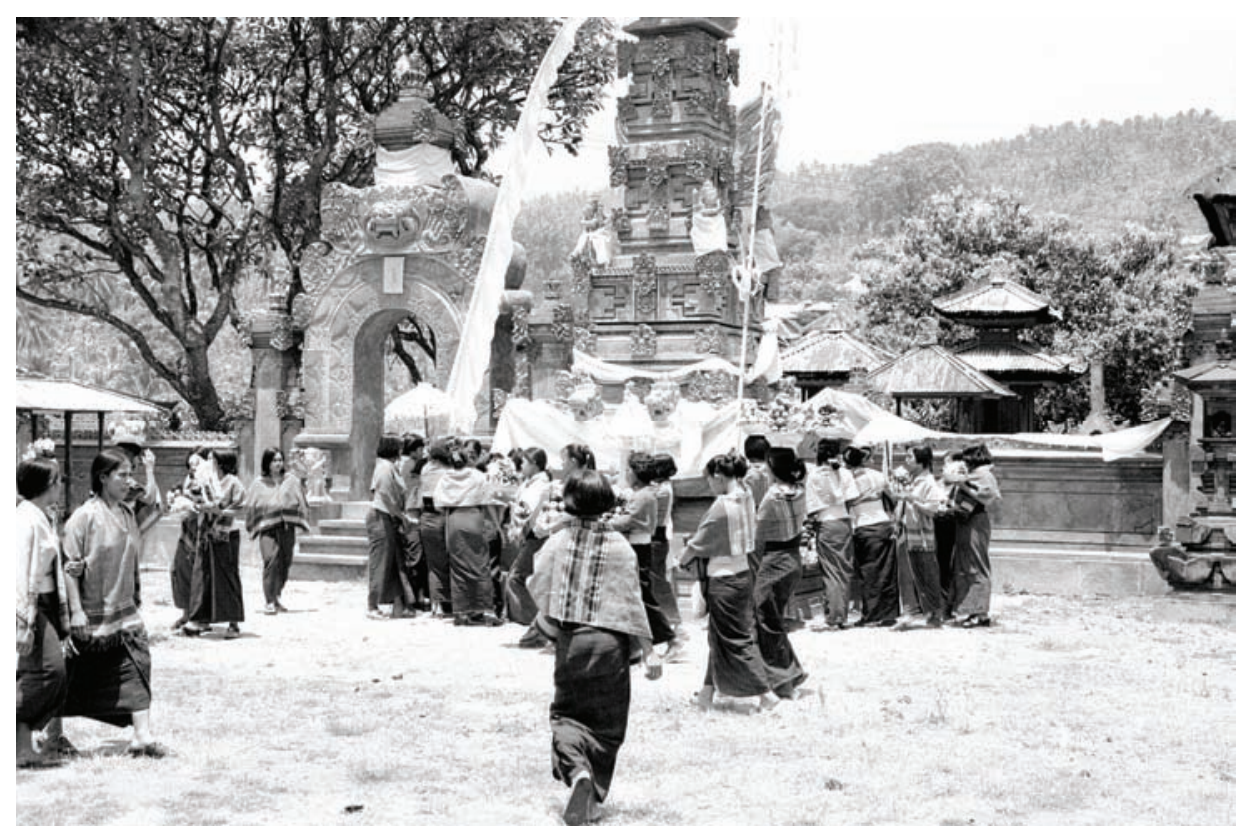

Photo 4: Members of the daha association in the Village Temple at Galungan Festival.

Photo: Brigitta Hauser-Schäublin 1997.

All these ritual associations are organized on principles of duality and seniority (see Hauser-Schäublin this volume). The elder daha tua have administrative, organisational and ritual functions. They advise and support the daha bunga in their duties to bring rice, other food and sweet palm wine, flowers and other components for offerings (Photo 5) etc. and to prepare offerings and the food, which is divided and arranged under the guidance of daba tua, and consumed in common by all members (Photo 6).

\footnotetext{
${ }^{26}$ In 2001, the association counted around 190 members, out of which about $60 \%$ attended Galungan; only 10 to 15\% were present on Buda Wage days (Fieldnotes Christa Schot, 2001).
} 


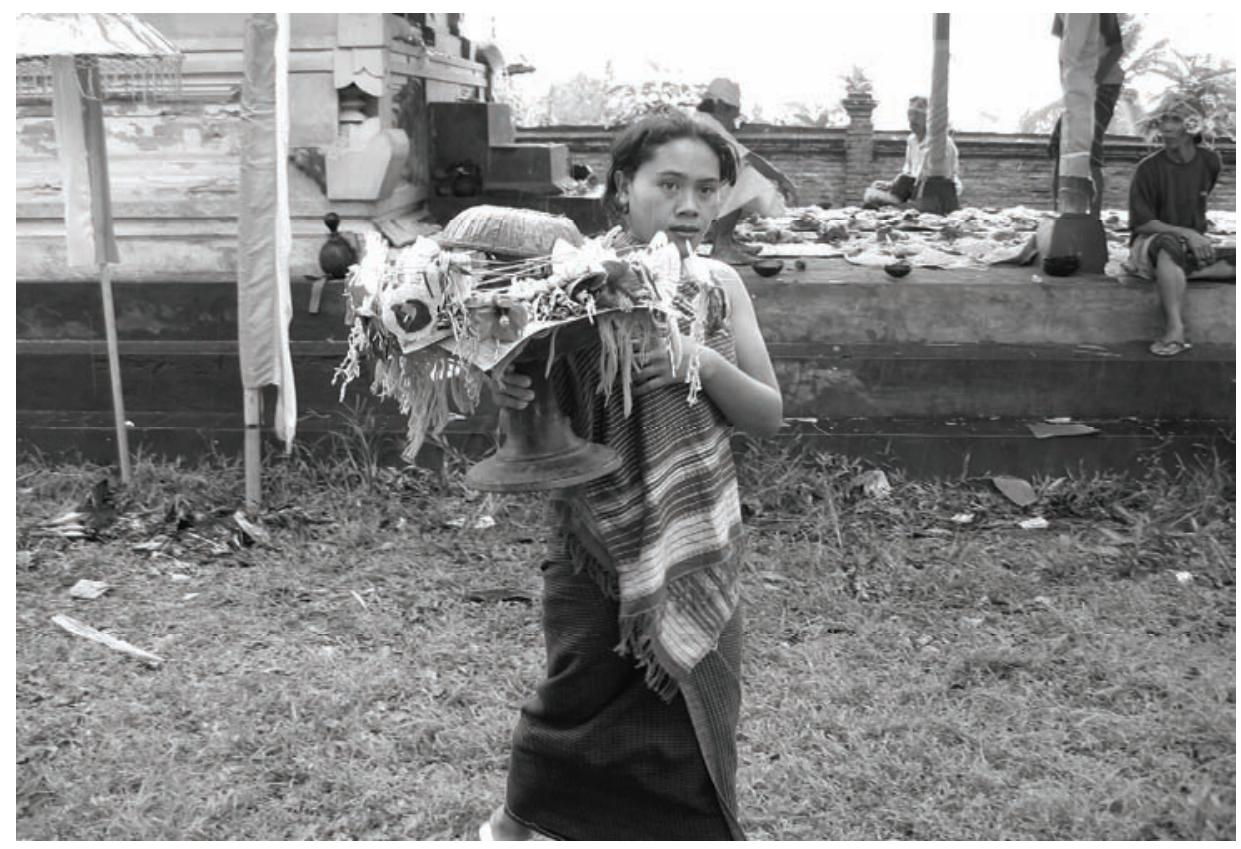

Photo 5: A young daha bunga with the characteristic daha bunga flower offering at Kuningan Festival.

Photo: Brigitta Hauser-Schäublin 2005.

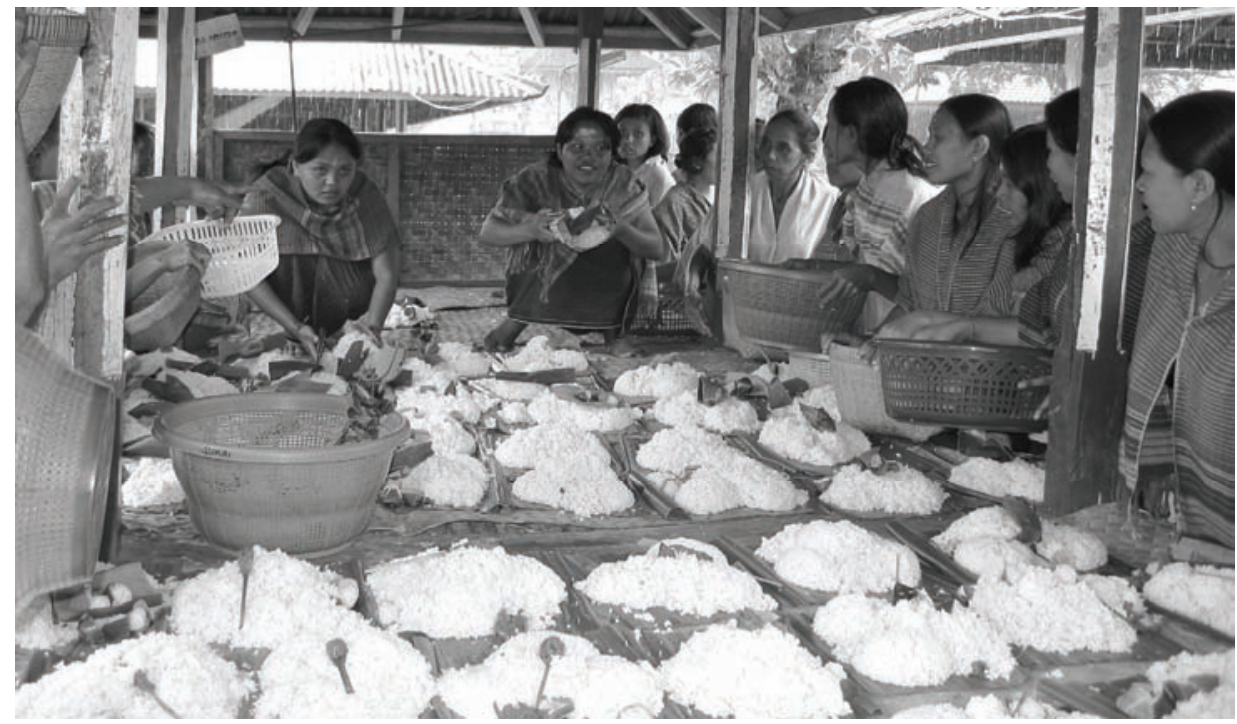

Photo 6: Preparation of the common meal for the daha at Kuningan Festival. Photo: Brigitta Hauser-Schäublin 2005. 
Up to the 1970s, the unmarried daba bunga, who are regarded as pure (suci), also performed ritual rejang dances at Galungan and Kuningan festivals. These days, there is only a small group of girls that dance in public on the occasion of village contests (lomba desa) or Bali Art Festivals (pesta seni). ${ }^{27}$

On all these occasions, the daha mark their membership of the association by wearing a very special form of dress which is entirely made of cloths woven in Sembiran (Photo 7).

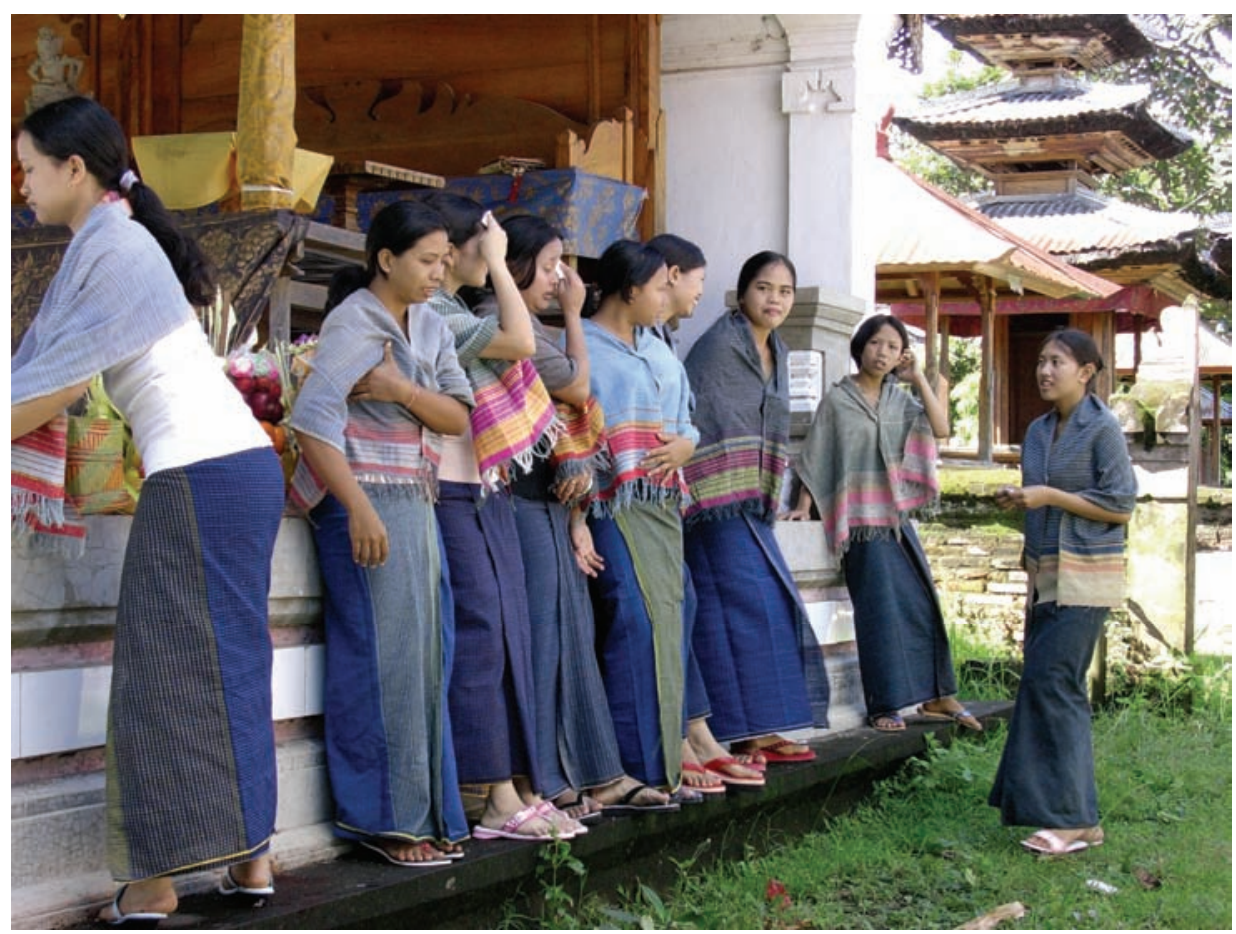

Photo 7: Young daha bunga at Galungan Festival, showing the varieties of hipcloths and shoulder-cloths. Photo: Jörg Hauser 2005.

They are clad in a long, open hip-cloth (kamben), wrapped tightly around their bodies and falling down to their feet. It is usually of dark blue indigo colour with extremely thin, undyed warp and weft stripes that produce a discreet check design. There are, however, quite a number of variations: from plain blue cloth up to refined forms with a middle section of slightly different colour and check design. The upper part of the body is tightly wrapped from hips to armpits with a long,

${ }^{27}$ Detailed information on the daha association is based on personal communications of Brigitta Hauser-Schäublin and fieldnotes of Christa Schot. 
narrow, usually white band (sabuk), forming a kind of corset. Many young women have replaced it by a more fashionable corsage of elastic material, called streples, and a bra (Photo 8).

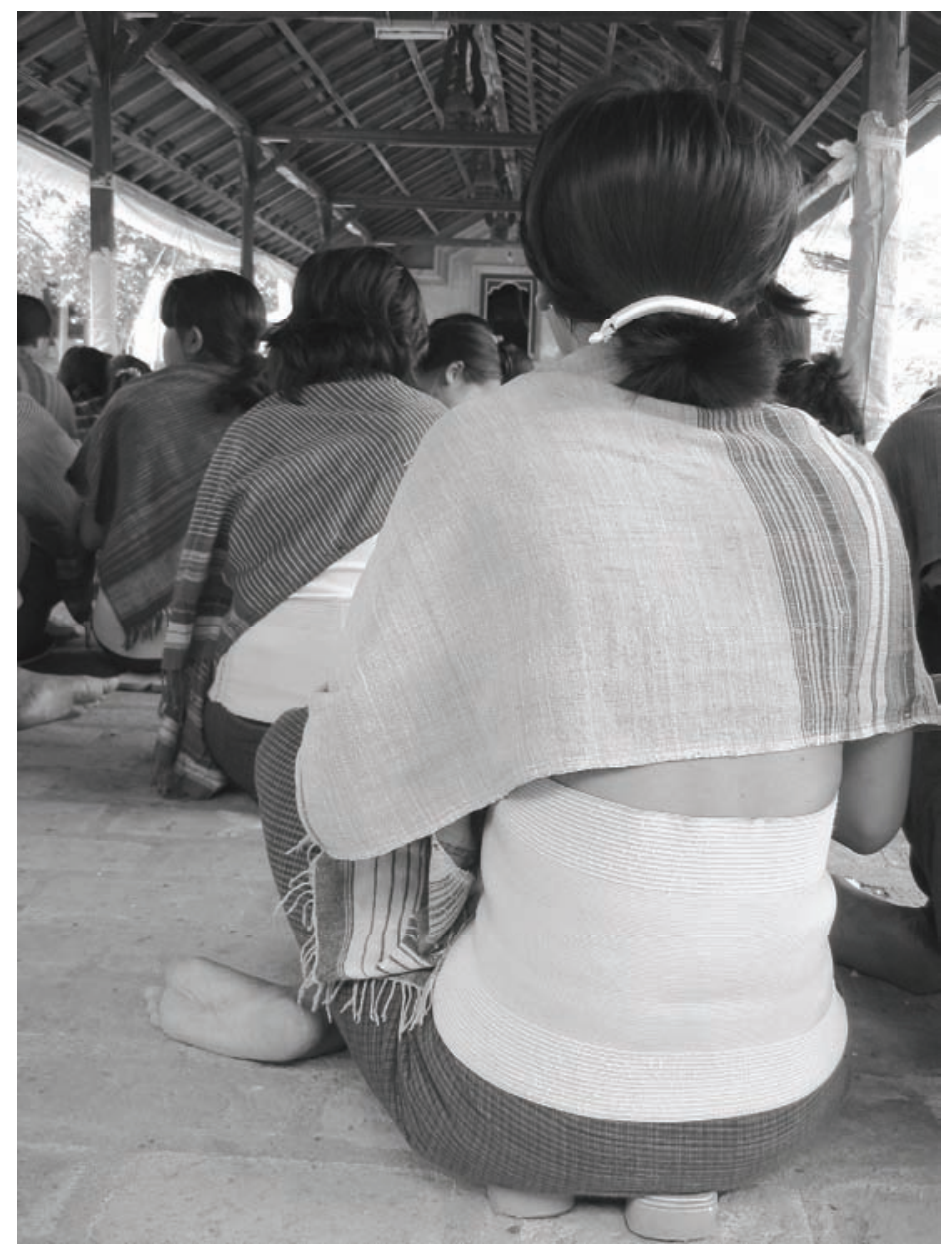

Photo 8: Daha gathering at Galungan Festival in the Bale Agung. The photo illustrates the many variations of stripe designs and ground shades (grey, indigo blue, black). The young daha bunga prefer to wear a modern streples of pastel colour instead of the old-fashioned white sabuk. Photo: Brigitta Hauser-Schäublin 2005.

Both shoulders and the body are then completely hidden under a shoulder-cloth (selendang, local name banja, or panja) with fine, carefully twisted fringes (kucih) which Sembiran women consider to be a very important sign of quality. The banja is fixed over the bosom by means of a safety pin or held in place by hand. It is 
dark indigo blue (some dyed with synthetic colours are faded to pale blue or grey) with thin, white weft stripes and broader, coloured bands in the center and at both ends (pala), called sisih. $^{28}$ There are many variations in the arrangement of these bands in terms of width and succession, but they ultimately have to be white, yellow and red.

My surmise according to which these primary four colours might symbolize the four points of the compass, and hence the divine powers as in several other Balinese textile categories ${ }^{29}$, was not confirmed by Sembiran women. Nor did they see any relation between the number and arrangement of the stripes to certain clans, nor to the wearer's hierarchical position within the daba group. On the contrary, it is obvious that some old daba tua wear undyed greyish shoulder-cloths (Photo 9).

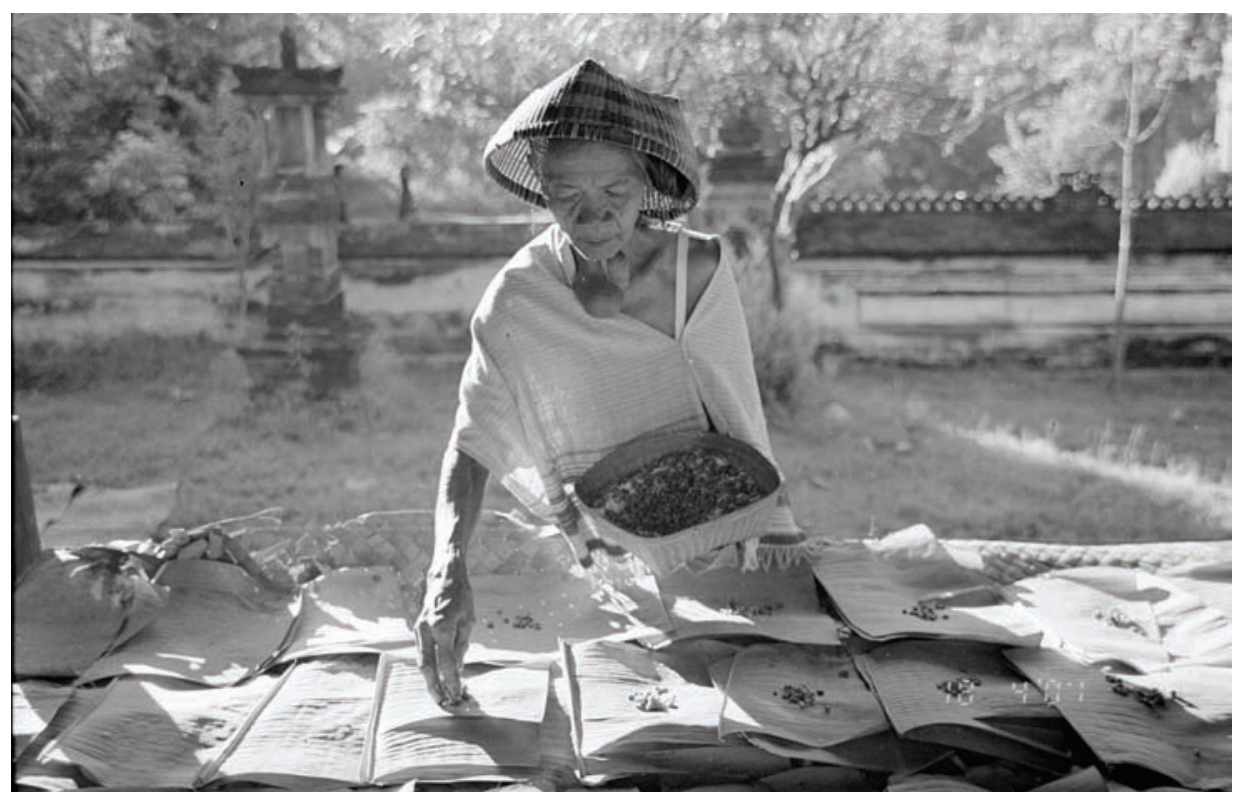

Photo 9: An old daha tua at the meeting sangkapan in the Village Temple on the day Buda Wage. Photo: Christa Schot 2001.

But sometimes, shoulder-cloths of old women just look grey, because their synthetic colours have completely faded away through sunlight and washing. Young

\footnotetext{
${ }^{28}$ In old and modern Javanese, sisib means "two, one at each end" (personal communication from Rens Heringa).

${ }^{29}$ Hauser-Schäublin, Nabholz-Kartaschoff and Ramseyer 1991:60, 72-73, 78, 92, 114.
} 
daha may also wear such faded cloths; however they prefer gaudy colours and feel ashamed of wearing such tired-looking ones. ${ }^{30}$

As a matter of fact, the Sembiran unmarried women's dress code of covering their bare shoulders is extremely unusual for Bali, and we do not know of any other local culture in Bali hiding women's bare shoulders like this. Is it a relic of a much older form of dress that disappeared long ago from other parts of Bali and beyond? ${ }^{31}$ Daha tua say that their garb corresponds to the form worn in olden times, and that the only modern change was that young girls prefer an often pastel-coloured girdle-cloth or a streples and a bra instead of a sabuk. ${ }^{32}$ Does this rather "puritan" sense of shame and modesty reflect a relic of Islamic influence (see Hauser-Schäublin 2004)? ${ }^{33}$ The answer is, as given by most of Sembiran informants, more pragmatic. Until a few decades ago, the bania was tightly wrapped around women's chest. The shoulder part above the breast had to remain naked to allow older people to check, if any of the girls was pregnant; pregnancy was thought to be recognised by bluish veins above the breast. In fact, a pregnant girl would immediately loose her daha status, and she would be absolutely forbidden to enter a temple, because she was not considered to be pure anymore. In the course of modernization - after women had started wearing bras - naked shoulders were considered shameful. Therefore the daba started to wear the banja as a shoulder cloth.

After the death of a daha, her ceremonial attire was in former times buried with her corpse. ${ }^{34}$ Today, it is inherited by her nieces, or sold. ${ }^{35}$

Unmarried boys and men, teruna, have, in principle, to fulfil comparable duties and hold gatherings similar to the daha. But as many young men have left the village to work elsewhere, the members of the teruna association are much less active than

\footnotetext{
${ }^{30}$ Personal communication from Brigitta Hauser-Schäublin, 2006.

31 According to Rens Heringa, the style of wrapping both shoulders in a selendang or mantle is known in Java as rimong; it is typical for the bride costume in Tuban, or for dancers in Jogjakarta. Sumaryoto (1993:35) describes the leading character of a $20^{\text {th }}$-century Javanese novel as wearing rimong limar katangi, and comments: "rimong is a selendang ("long wide shawls worn over the shoulders')"; and finally, moving to more Eastern islands, we may observe that dancers and young noblewomen in Roti use to wear an ikat selendang over the shoulders (Breguet 2006:149; Guy 1998:Ill. 119).

To my question as to whether it might possibly correspond to clothing traditions among Sasak Wetu Telu in Lombok, Sven Cederroth answered that he had never seen anything worn like this in North Lombok. However, he continued: "I think that it resembles quite closely the South Lombok festive dress". I have not yet found time to follow up this idea. 32 Fieldnotes from Christa Schot, 2001.

${ }^{33}$ Like the renunciation of butchering and consuming pigs and of their use in offerings in agama slem rituals (Hauser-Schäublin 2004:46-47).

34 Personal communication from Hauser-Schäublin, 2006

${ }^{35} \mathrm{It}$ is the custom in Sembiran to bury a corpse together with a few objects, such as clothing, an umbrella, etc., that might be useful to the deceased person on her way to the upper world (Riemenschneider 2004:84-85; Riemenschneider and Hauser-Schäublin 2006:43), Fieldnotes from Christa Schot, 2001.
} 
the daha, and there are only few gatherings. ${ }^{36}$ Presumably, teruna members also had their special form of attire in former days, yet it is no longer worn. As it is often the case, men depart more easily from old dress codes than the more conservative women. At weddings, however, bridegrooms are clad in a very special outfit, which possibly corresponds to an ancient teruna style of clothing that has now disappeared.

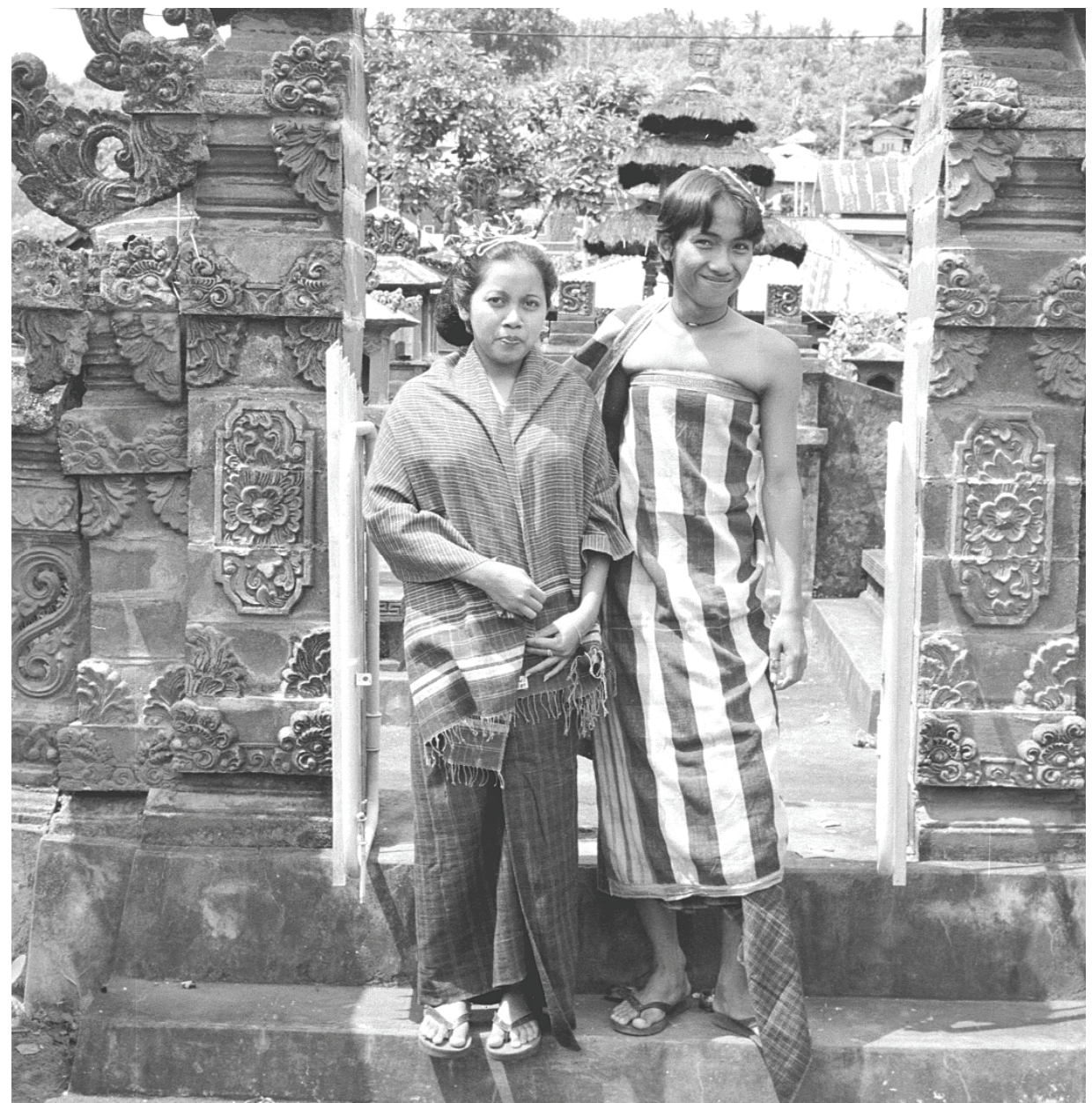

Photo 10: Young couple in traditional wedding dress at the entrance to clan temple.

Photo: Brigitta Hauser-Schäublin 1998.

${ }^{36}$ Teruna are for instance supposed to hold gatherings every new moon, Tilem. 
During the first parts of their wedding, bride and bridegroom wear festive clothing (pesaluk) entirely made of textiles woven in Sembiran (Photo 10). ${ }^{37}$

As a matter of fact, the bride - and we suggest the bridegroom, too - are by means of this traditional garb marking their final departure from unmarried status during this important life cycle ritual.

Thus, the bride's attire is the daha clothing as described above. The groom is wearing a kamben of the same type, dark indigo-blue with minute white check design, draped in pleats and knotted in front, and fixed with a belt-like sash (sabuk) in bright orange and red shades. Over this, he wears a second broad cloth (saput) knotted on his right hip, and wrapped around his body, coming down from his armpits to his calves and with one corner tip drawn over his back and his right shoulder. Its design consists of big dark blue and white checks (poleng) with red and yellow stripes at both ends; a narrow decorative band (tepi) with supplementary warp patterns is sewn to the upper border.

This apparel is worn during the first parts of the wedding ceremony at a ritual common meal of the couple, and at the so-called "small marriage ritual" (peragat nik-beakawon) which symbolically marks their transition from unmarried to married status. Their appearance in bachelor's garb marks their status as being still members of the organisation of unmarried people. This ceremony takes place in the family temple of the bride's family, or in a special sacred room (pengijen) in their house. On this occasion, the bride asks her ancestors for permission to leave her clan (dadya) before joining that of her future husband. The couple continue to wear this garb during a procession through the village during which they bring offerings to different relatives and pray at different places, as also at the "big marriage" ceremony (peragat gedé-penyari) in the temple of the bride's family. After a feast gathering of both families, the married couple dress up in the conventional Balinese festive wardrobe (Riemenschneider 2004:68-69, 106-107; Riemenschneider and Hauser-Schäublin 2006:32-33, Photo. 9-10).

Only couples who both originate from Sembiran would wear this garb of the daha and teruna organisations, whereas a couple with a bridegroom from Gianyar, or another one with a bride from Sumatra did not. At a purification ritual (ngotonin - ngeraja singa / ngeraja sewala, see Hauser-Schäublin this volume) which one couple had to go through before the actual wedding ceremony, the bride did not wear the daha banja over her shoulders as usual, but wrapped it as a breast-cloth in the old style, as in Balinese adat clothing of the highest level. ${ }^{38}$

In spite of rich field research material on Sembiran in terms of notes and illustrations, I have not met with one single old textile from the village that was used

${ }^{37}$ A full set of attire for a Sembiran bridal couple from around 1950 is kept in the Museum der Kulturen Basel, nos IIc 21399-21403. The hip-cloth of the bride is of an older type with a central section in red silk (see Photo 14). The check design of the bridegroom's kamben is not composed of white but pale blue stripes; the originally white and blue cloth has apparently been refreshed by over-dyeing with indigo (sembuban).

${ }^{38}$ Field photographs from Christa Schot, 2001. 
in a ritual context, either in offerings or in any decorations for sacred objects or buildings. The only likely exception was a shrine outside the village near the burial-ground. At this Pura Rajapati, or Pura Ngelumbahan, the third purification ritual (ngelumbah) for the deceased is performed by his dadya 42 days after his demise (Riemenschneider 2004:88-90; Riemenschneider and Hauser-Schäublin 2006:47). This sacred place is the seat of Dewa Rajapati who will accompany the soul of the deceased to his "ancestors" village". The stone seat, where an anthropomorphic figure representing the departed person is deposited, is clad with a very old, faded textile which seems to be a typical Sembiran cloth, possibly a banja with the characteristic end stripes (Photo 11).

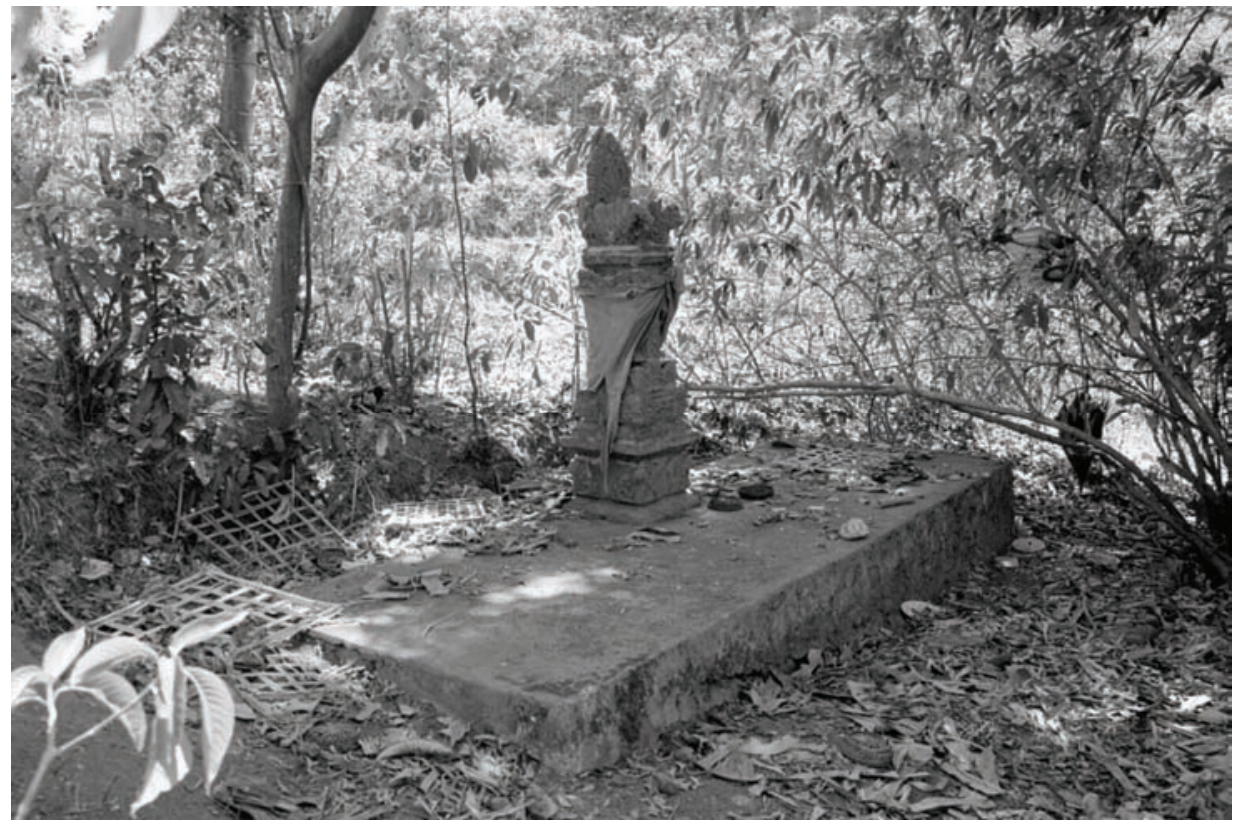

Photo 11: The stone seat of Dewa Rajapati is clad with a faded Sembiran textile.

Photo: Christian Riemenschneider 2003.

From time immemorial, a special kind of outer hip-cloth used to be woven in Sembiran for the two kubayan, heads of the ritual village community of Sukawana (Photo 12), who hold the highest ritual offices (Hauser-Schäublin 2003:167; Reuter 2002:13th Ill.,196-197). It is a simple white cotton cloth with thin dark indigo-blue weft and warp stripes, forming a check design, and called saput kotak- 
kotak pelung ("outer hip-cloth with dark blue check pattern"). 39 This kind of textile was never used in Sembiran itself. ${ }^{40}$ Under this saput, the kubayan wear a nearly black kamben with a check design of fine white stripes. It looks like the hip-cloths of the daha mentioned above, and could have been woven in Sembiran, too. The same type of cloth is used as kamben by the wife of a kubayan who also holds a high position in accomplishing rituals (Photo 13).

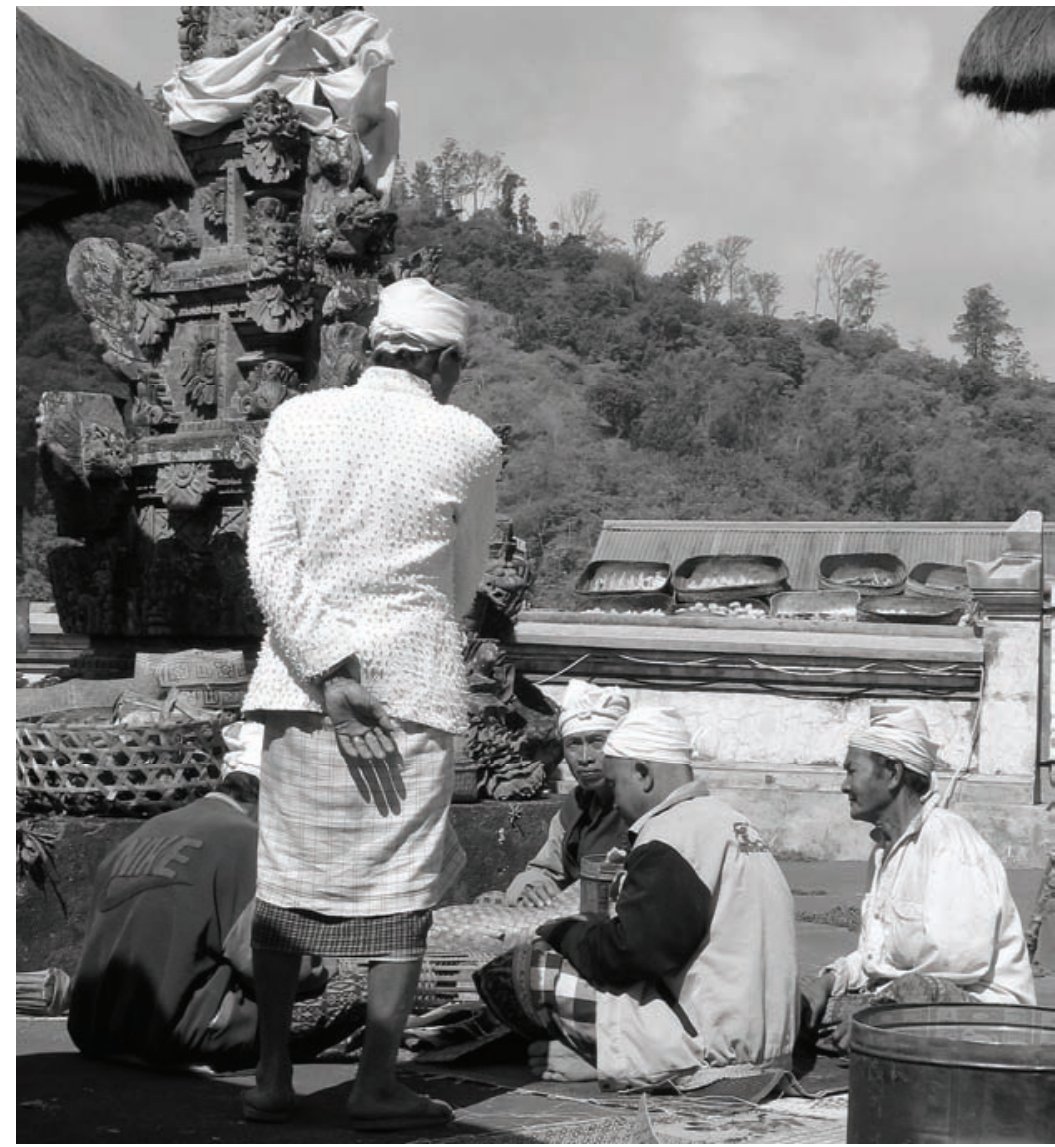

Photo 12: Kubayan of Sukawana at a Tilem Karo celebration, wearing a saput kotakkotak pelung from Sembiran over a nearly black kamben with check design, probably also from Sembiran.

Photo: Jörg Hauser 2004.

39 This cloth is of exactly the same type as the saput gotia, worn in Tenganan Pageringsingan by married women as a kind of "working garb" for performing certain sacrifices and other ritual activities (Ramseyer 1984:208-210, figs. 3, 6-9,16). These gotia as well as other checked cloths have either been manufactured in the village or ordered from a neighbouring village, and were not made on the typical Tenganan loom for weaving geringsing, but on a single-level loom (Ramseyer 1984: 203).

${ }^{40}$ Personal communication from Brigitta Hauser-Schäublin, 2006. 


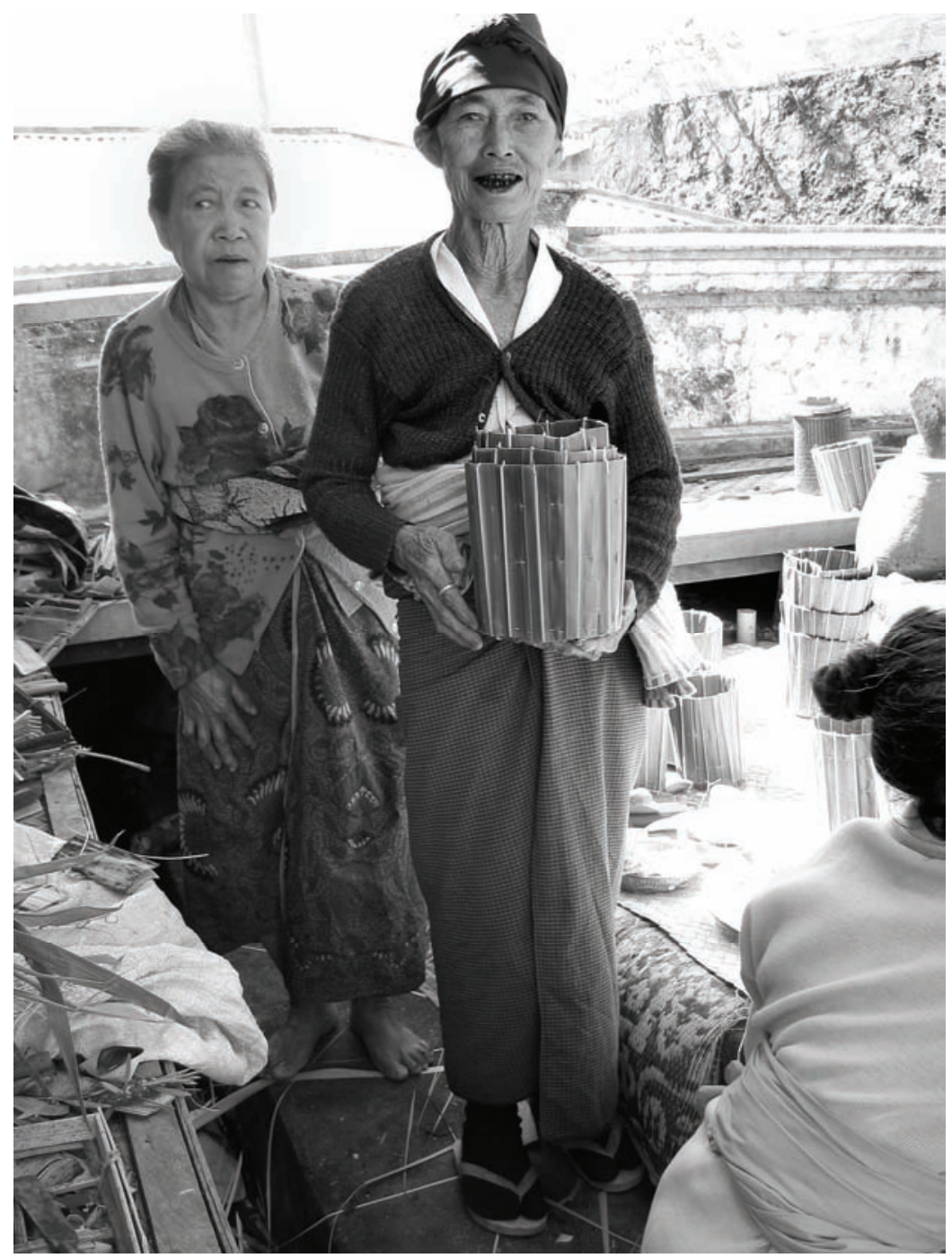

Photo 13: Wife of kubayan of Sukawana at a Tilem Karo celebration, wearing an indigo blue kamben with white check design, probably manufactured in Sembiran.

Photo: Jörg Hauser 2004.

Of course, Sembiran was not the only village to manufacture cotton cloths in North Bali. Fraser (1908:324) reports that Sembiran was the most important cotton weaving centre, whilst other villages only wove a few cloths for ceremonies such as, for example, tooth filing. Let us just briefly exemplify: Julah and Pacung were important cotton cultivation and weaving centres long ago. Julah still produces plain white cloths nowadays; and in Pacung weaving traditions have sur- 
vived up till now and have successfully been revitalized through the activities of the Surya Indigo Project. ${ }^{41}$ Weaving in Kubutambahan is confirmed by a selendang with a check design of white, yellow, red, olive, blue, and black weft and warp stripes. ${ }^{42}$

\section{Kain kumalo - A Textile from Outside Sembiran}

In Sembiran, a very particular kind of hip-cloth was formerly used by women as part of their wedding costume or as an outfit for presenting offerings and praying at festivals (maturin). It could be considered a luxurious and more colourful variation of the usual ceremonial kamben of daha and brides (Photo 14).

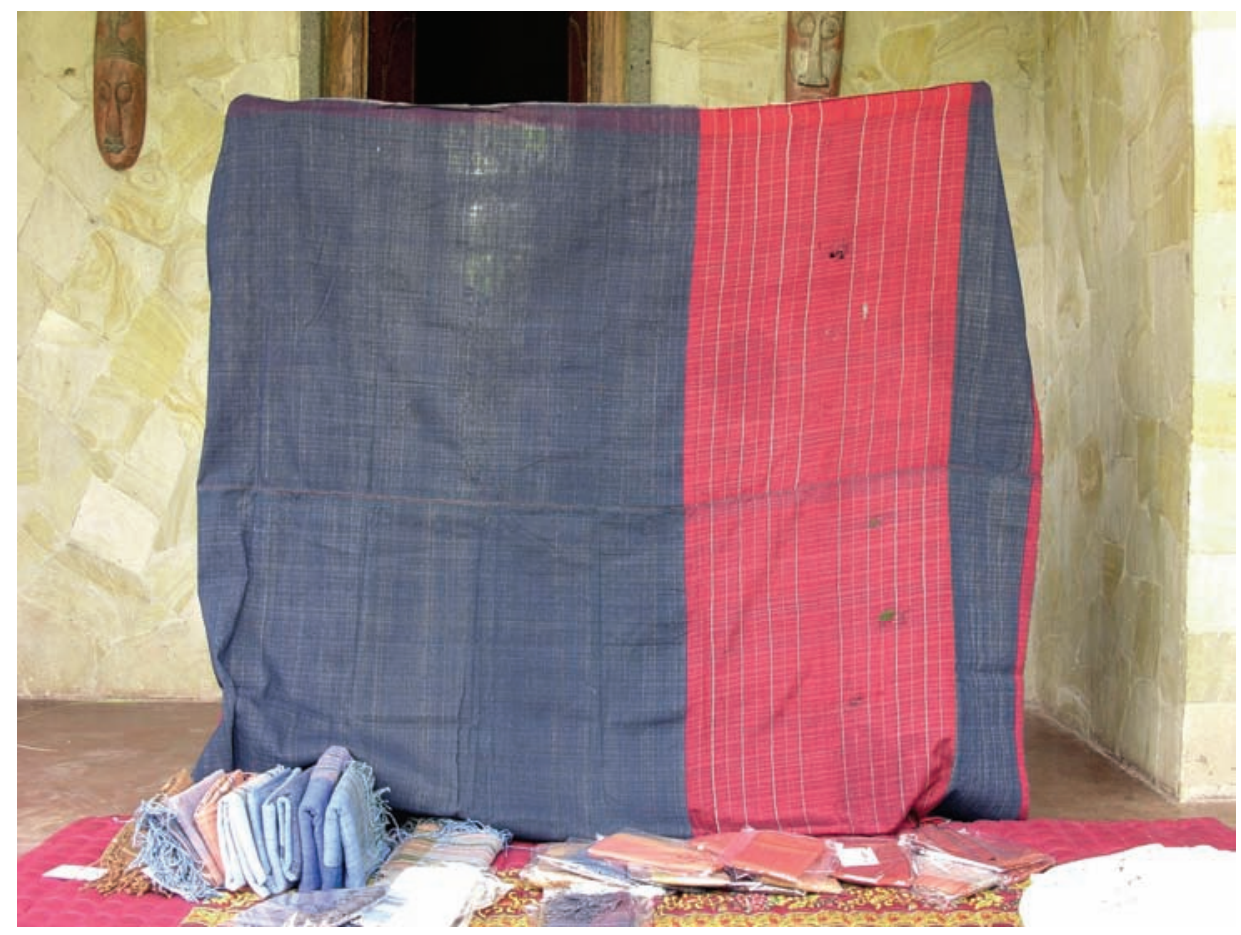

Photo 14: Old kain kumalo from Sembiran, acquired by the Surya Indigo Foundation in Pacung.

Photo: Brigitta Hauser-Schäublin 2004.

${ }^{41}$ Personal communication from Rens Heringa, 2006.

${ }^{42}$ No. 25992, Wereldmuseum Rotterdam, collected by L.C. Heyting before 1924. 
Informants from Sembiran call it kain kumalo, or are speaking of sutra kumalo ("kumalo silk"). ${ }^{43}$ Its over-all design has the same structure as the usual daha hipcloth: dark blue or black lateral parts with thin white stripes in the warp and weft, forming a discreet check design; its decorative panel (kepala), however, is of a luminous red with narrow white weft stripes. This kepala may be set in the center of the cloth, but in most cases it is shifted towards one end. This led to the fairly common assertion that kain kumalo with a central kepala were associated with male dress, the ones with an asymmetrically placed kepala with female dress. These hipcloths are always composed of two webs (from 61 to $72 \mathrm{~cm}$ wide), sewn together to achieve a total width (or height when worn, respectively) of about $140 \mathrm{~cm}$. The basic material is cotton; but the extremely fine white warp and weft stripes of often only single pairs of threads consist of undyed ramie, as on the Kintamani breast-cloth mentioned below (p.94). Outside Bali, this feature of fine lines of only single pairs of warp threads of ramie occurs on old Minangkabau textiles from Sumatra (Summerfield 1999:203-204). ${ }^{44}$ The red weft of the kepala is a rather coarse, only slightly twisted mulberry silk yarn, dyed with lac-dye ${ }^{45}$, and in more modest forms a most probably mengkudu-dyed cotton thread (p.78). Some simpler models have no silk, being entirely woven from cotton.

As a matter of fact, we will have to consider three new components in our study, namely silk, ramie, and the dyestuff lac.

There is apparently "no evidence for silk weaving in Bali during the 9-14th centuries, although it is likely that silk textiles reached the island through trade" (Stuart-Fox 1993:90). In pre-colonial and colonial Bali, no silk was cultivated in Bali itself. ${ }^{46}$ This precious raw material was essentially imported from China, usually

\footnotetext{
${ }^{43}$ One example could be acquired by Brigitta Hauser-Schäublin for the collection of the Museum der Kulturen Basel, no. IIc 21400, see note 37.

${ }^{44}$ Among the Minangkabau, this material is called ramin. Bast fibers of Boehmeria nivea or another Boehmeria species are not spun, but their ends are joined by knotting or twisting the ends of the fibers (Summerfield 1999: ills. 8.6 and 8.7; Personal communication from Summerfield, 2006). This extremely fine yarn is only found on Minangkabau textiles that are at least one hundred years old.

${ }^{45}$ Degummed mulberry silk Bombyx mori L. and the dyestuff lac from Kerria lacca (Kerria 1872) have been analyzed in a similar textile (Museum der Kulturen Basel, no IIc 14027) by the Koninklijk Instituut voor het Kunstpatrimonium, Brussel, 2003; the use of lac-dye has also been confirmed on the piece from Sembiran (Museum der Kulturen Basel, no. IIc 21400 ) by Dr. Harald Böhmer and Dr. Recep Karadag, Marmara University Istanbul. ${ }^{46}$ Only the province of Aceh in North Sumatra and to a lesser extent Lampung in South Sumatra and later South Sulawesi produced silk from the 16th to the 19th centuries. It might be possible that, because of intensive inter-island connections of North Bali, the material used in Buleleng was imported from Sumatra (see Salmon 2005; Nevermann 1938:43).

Recently, Georges Breguet was told by members of a Brahmin griya in Budakeling, that silk worms had been reared there up to the 1970s; one member remembered having helped her mother to unwind silk from cocoons when she was a child.

The processing of silk in Bali and Lombok has been described in detail by Jasper en Pirngadie (1912:47-48).
} 
through Chinese traders. ${ }^{47}$ That this was the case in North Bali, we learn for instance from Chinkak, the Chinese master of a Siamese merchant junk, who sailed from Bangkok via Singapore to Buleleng in 1845-46, and who wrote a detailed report about trading and living conditions in North Bali. Among the goods for exchange trade, he carried raw silk, silk cloths and gold thread (Graves and Kasetsiri 1969:83, 95, 102). According to the Dutchman Van Eck (1880:20), import goods in the main port of Pabejan Boeleleng in 1873 included considerable amounts of coarse raw silk, gold leaf and gold thread. These luxury items were in demand among aristocratic circles. In general, silk was considered to be a sign of prestige for the families of the royal court who claimed the exclusive right to weave and use silk clothing. Let us again refer to Chinkak's report on his official visits; he meticulously described how local aristocrats and high officials in Buleleng were dressed in silk (Graves and Kaset-siri 1969:89-98).

Ramie (Boebmeria nivea Gaudich) is a typical textile raw material in China, Formosa and the Philippines. ${ }^{48}$ A report on an expedition of the Ming emperors to the kingdom of Majapahit mentions ramie among the goods brought from China (Yoshimoto 1988:175). According to Bally (1957:10), it is highly probable that the Chinese brought the ramie plant to Indonesia. ${ }^{49}$ The Chinese ramie is known as "white ramie", or "China grass". There are, however, also indigenous kinds of Boehmeria in India and Southeast Asia. They belong to several forms forms of socalled "green ramie" (Boebmeria tenacissima or Boebmeria utilis, Indian name: rhea) which appear to be better suited to tropical conditions. Boehmeria sanguinea Hasske., for instance, was used for knotting fisher nets and weaving cloths in Java (Heyne 1927:585-586; Junghuhn 1842-54 I:175). "Green ramie" grows wild or is cultivated on a small scale in Bali, too, where it is sometimes called bagu. ${ }^{50}$ It is possible

\footnotetext{
${ }^{47}$ Fraser 1908:325, 327; Nevermann 1938:44.

48 Bally 1957:4, 6, 13-14.

49 Jasper en Pirngadie 1912:52-53; Nevermann 1938:23-24; Van Bloemen Waanders 1882. As early as in the $19^{\text {th }}$ century the cultivation of Boehmeria nivea was fostered in Java by the Dutch for export to the Netherlands. During the Japanese occupation, the cultivation of ramie was particularly emphasised in Java and Sumatra (Bally 1957:10).

${ }^{50}$ There seems to be some confusion as to the translation or interpretation of the term bagu: The dictionary Kamus Bali-Indonesia edited by I Wayan Warna (1978) translates the word bagu as "serat" (fiber), "rami" (ramie), the Kamus Bahasa Bali by Sri Reshi Anandakusuma (1986) as "rope of rice straw". According to informants in Mungsahan and Catur (1988), it means ramie. However, it may also be used for other bast fibers, in Sembiran for instance for pineapple fibers (information from the Kelian Desa in 1988). Van der Tuuk (v. 4, p. 1044) explains bagu as "vezels in't blad v.d. ananas, in den bast v. versch. bomen of planten", thus pineapple fiber, too, or bast fiber of other trees and plants. Finally, Susi Johnston informed me that "bagu or bagoe or bago are different terms in Balinese, Javanese, Kawi, and various other local languages used on other islands for the melinjo or belinjo tree (Gnetum gnemon L.)", and that the bast fibers of this tree are used in Bali to manufacture ropes, strings for nets, and paper. Gnetum is also present in Java and serves for the manufacture of ropes and paper (Junghuhn 1842-1854:175; Jasper en Pirngadie 1912:52; Heyne 1927:121-122). However microscopic analysis of the core fibers of the gold thread mentioned below (p. 19-20) confirms that they are ramie, not Gnetum.
} 
that Balinese used their own ramie for weaving instead of buying it from outside. ${ }^{51}$ In any case, ramie appears only rarely in Balinese fabrics, as for instance in a particularly interesting ceremonial breast-cloth which was attributed by its former owner to Sembiran, or some village in the Kintamani region. ${ }^{52}$ This hand-spun cotton fabric has a rather loose structure of varying density; its check design is formed by single pairs of undyed ramie threads in the warp and weft, and thick gold threads with a ramie core in the weft. Outside Bali, this feature of fine lines of only single pairs of warp threads of Boehmeria nivea occurs on old Minangkabau textiles from Sumatra (Summerfield 1999:203-204). ${ }^{53}$

Lac-dye ${ }^{54}$ is the product of different kind of lac insects of the family of Lacciferidae; the most frequent species used is Laccifer lacca Kerr. (synonym Coccus lacca). Their females produce a resinous secretion on twigs of host trees. These encrustations include the red colour lac-dye contained in the female insects, and a resinous substance used for producing lacquer (shellac). Lac is a mordant dye which acts in combination with alum and sour constituents (tamarind, citrus fruits, or alike). It produces a cool red with a slightly bluish hue; by mixing with or dyeing over other colours, or by using another combination of mordants, all kind of shades from warm red tones to dark purple or violet can be obtained.

Dyeing with lac, mainly on silk, was wide-spread throughout India, Continental South-East Asia (in particular in Thailand, Burma) and the west of the SouthEast Asian archipelago; since the second half of the $19^{\text {th }}$ century it has been gradually supplanted by cochineal and synthetic dyestuffs.

In Indonesia, lac is known under the name of blendok trembalo in Java, or ambalau in Sumatra (Jasper en Pirngadie 1912:73-75), where it was mainly used for dyeing red silk. In the first half of the 19th century, an indigenous, nondomesticated form of lac (Carteria lacca Kerr) used to be collected in the forests of these islands. ${ }^{55}$ Raffles (1817, I:170) reports: "Stic-lac, used in dyeing, is procured in many parts of Java, and can easily be obtained in a quantity sufficient to meet

\footnotetext{
${ }^{51} \mathrm{It}$ is very difficult to determine exactly the different types of the genus Boebmeria. Even Summerfield (1999:205-206) in his detailed study of the use of ramie among the Minangkabau, had to refer to future analyses to be made by Sumatran botanists.

52 No. IIc 20689, Museum der Kulturen Basel.

${ }^{53}$ Among the Minangkabau, this material is called ramin. Bast fibers of Boebmeria nivea or another Boebmeria species are not spun, but their ends are joined by knotting or endtwisting (Summerfield 1999: ills. 8.6 and 8.7; personal communication from John Summerfield, 2006). This extremely fine yarn is only found on Minangkabau textiles that are at least one hundred years old.

${ }^{54}$ For detailed information on lac-dye see Böhmer 2002:208-209; Bühler 1948:2787; Gittinger 1992:28, 245; Kajitani 1980:317; Mohanty 1987:56, 75, 82.

55 Salmon 2005:10, following Jules Itier: Journal d'un voyage en Chine en 1843, 1844, 1845, 1846. Paris 1848-53:36.
} 
the demand." The best quality, however, was cultivated lac from Burma, particularly the one imported from Pegu. ${ }^{56}$

We have no information on possible lac cultivation for Bali, but lac-dyed silk yarn frequently appears in early songket fabrics with beautiful patterns worked in gold and silver thread. The weavers of Sembiran, however, had never ever heard of such a dye-stuff.

We came across several textiles similar to the kain kumalo type of Sembiran. They are attributed to different regions of Bali57, and were used as hip-cloths for women and as over-hip-cloths (saput) for men. The Sembiran piece mentioned above was worn as a bridal hip-cloth and may be also worn as part of the daha garb. Sembiran informants, however, insisted that this was long ago; the weaver Ni Ketut Sri Ngentek reported she had bought, and not woven herself, such a kamben at the request of her ancestors; other women confirmed they had done so as well. Older informants added that women sometimes cut out the red panel as they felt embarassed to wear it over their buttocks ${ }^{58}$; this remark expresses the same sense of modesty as mentioned above (p.85). The black and red cloths could also be used in a ritual context: a textile of this type was for instance laid out, together with a sacred cepuk cloth and white and yellow fabric, on the occasion of a purification ritual of a family temple in Kerambitan (Tabanan) in order to create a pure site for symbols representing ancestors.

We have no evidence for any of the samples as to where they might have been woven, with one very interesting exception: both weavers in Sembiran insisted that such fabrics had never been manufactured in their own village, but had been bought from Lombok dealers from Timbali, a village near Gretek and Tembok near the border between Buleleng and Karangasem. One of them incidentally remarked that the pattern was Sasak.

Another fact points towards such a possible relation with Lombok: The general Balinese appellation for these textiles is kain sara ${ }^{59}$, but other names were

\footnotetext{
${ }^{56}$ Heyd 1936:613 (Appendix); Jasper en Pirngadie 1912:76, following G.P. Rouffaer: Catalogus der tentoonstelling van Oost-Indische weefsels, 's Gravenhage 1901 give sample descriptions of the dyeing methods with lac.

${ }^{57}$ For instance, nos. IIc 14027, 14028, 14067, 14068, 14088 in the Museum der Kulturen Basel collected by Alfred Bühler before 1949 in South Bali (without any reference to precise provenance) and IIc 21400 acquired in Sembiran (see note 37); nos. 25645 and 25646 in the Wereldmuseum Rotterdam, collection L.C. Heyting 1924, attributed to Nusa Penida, and no 25973 from Buleleng with prominent red, blue and white weft stripes in the side parts, which is referred to by the collector as "kêmaloe"; nos. 1987.1082 and 1083 in the National Gallery of Australia in Canberra, dated 1900-1925, collection Mary and Michael Abbott 1987; one example coming directly from Sembiran in the collection of the Surya Indigo Project in Pacung; and some more in private collections in Leiden (acquired in Singaraja) and in the US.

58 Personal communication from Brigitta Hauser-Schäublin, 2004 and 2006.

${ }^{59}$ Personal communication from David Stuart-Fox, 2006: for sara, Van der Tuuk (v. 3, p. 51) gives different meaning derived from the Sanskrit and Old Javanese, but also: "bal. weefsel, halfroode zijde (z. kapala) en halfzwart; kamben sara sama”.
} 
heard in different places, for instance belasbas kemalu in Padangkerta, and kain kumalo in Sembiran. Informants there admitted that this word was not Balinese; its meaning was incomprehensible to them. ${ }^{60}$ We shall follow up this designation below.

As a matter of fact, we have found several examples of the same type of cloth in Dutch museum collections and elsewhere which originate from Lombok. ${ }^{61}$ The Wereldmuseum Rotterdam has a few very interesting old textiles showing exactly the same basic checked pattern structure with a central panel and two contrasting lateral parts. They may be executed in other colours. ${ }^{62}$

Sometimes, centre and side panels have the same basic colour all over, and the contrast is formed only by a different size and arrangement of the checks. ${ }^{63}$ By the end of the 1980s, shoulder and hip cloths with thin white lines forming a check design on a plain blue, or red ground were still worn as everyday clothing by Sasak Telu men in Central Lombok villages (Photo 15).

Finally, there is an example from the village of Suela in East Lombok in the Leiden museum, the pattern structure of which is exactly similar to the Sembiran piece described above (Photo14), but with opposite base colours: the central panel is dark indigo blue whilst the side parts are red. ${ }^{64}$

This type of fabric has been manufactured up to now in Lombok. On a short exploration trip in Lombok in 1988, we had the opportunity to see a woman in Central Lombok weaving such hip-cloths from mercerized cotton, with a pinkishviolet center panel. We acquired an example in Sukarara, which was called tapuk kemalu (tapuk is the Sasak word for "hip-cloth") 65 and we came across Sasak women from the village Ujung near Kuta wearing such tapuk kemalu at a wedding.

60 They also spoke of sutra kumalo, which could be a reference to the lac-dyed red parts. According to Rens Heringa, the word kemalo can be translated as "resin" or "lacquered", which might be related to the dyestuff lac. This word is used in Java, but it is not of Javanese origin. Van der Tuuk (v. 2, p. 344) explains the word kamalo as "jav., om garen te verven", and gives the example "sutra kamalo" without further explanation (Personal communication from David Stuart-Fox, 2006).

${ }^{61}$ No. 2407.269 from the village of Suela in East Lombok, in the Rijksmuseum voor Volkenkunde Leiden, acquired from Kleiweg de Zwaan in 1939; no. 74519 in the Wereldmuseum Rotterdam, a bridal cloth, most probably woven in Sukarara, Central Lombok, collected by C. Hagoort, 2000, and several examples called kemalu at a dealer's in Ampenan (1988), which, according to him, had been worn in Sembalun as part of the festive dress, either as kamben, or one half of it as selendang.

${ }^{62}$ For instance no 2153, collected by E. van Rijckevorsel before 1884, has thin cotton warp and weft stripes in white, yellow, green, blue and black colour and broader silk weft stripes on an overall red cotton base.

${ }^{63}$ For instance no. 27182 from Sasak Wetu Telu in Middle Lombok, collected by L.C.Heyting before 1924, is an extremely finely woven piece with an overall blue ground with thin white lines forming the check design. Its name, according to Heyting is kemali kain ragi kamok, and it was particularly worn at festivals and at common big feasts.

${ }^{64}$ No. 2407.271 from the village of Suela in East Lombok, in the Rijksmuseum voor Volkenkunde Leiden, acquired from Kleiweg de Zwaan in 1939.

${ }^{65}$ No. IIc 20383, Museum der Kulturen Basel. 
Also among Sasak in Lombok, we frequently met with different denominations bearing a resemblance to the word kumalo, which was used by Sembiran weavers, but not understood by them.

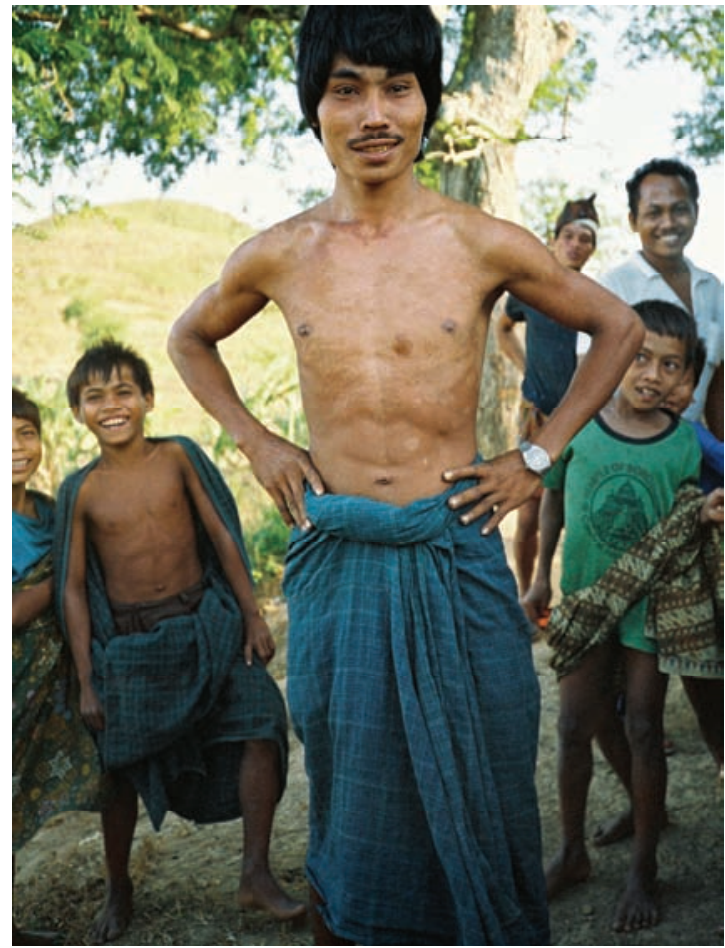

Photo 15: Young Sasak Wetu Telu man in everyday clothing. Central Lombok, village Lentok.

Photo: M.L. Nabholz-Kartaschoff 1988.

This seems obvious for the Sasak name tapuk kemalu just mentioned above. ${ }^{66}$ The word kemali or kĕmale is designating "a sacred place", or a "sacred cloth", or a "sacred object or stone". 67 Paul Wirz (1931:6,43-45) gives the variant kamáli or kambáli to magic cotton fabrics of the Sasak in Lombok, equating them to sacred Balinese babáli or wángsul cloths.

${ }^{66}$ According to personal communication from Sven Cederroth, 2006 "the word kemalu could be kemaliq which translates approximately as 'sacred' and which is the word used for the sacred cloths, the umbaq kombong in Bayan which are said to collectively belong to the category of kain kemaliq. The Sasak language has several dialects and the language spoken in South Lombok is quite different from bahasa Bayan, the language spoken in the North. Maybe kemalu is the South Lombok equivalent of the Bayan word kemaliq (the $q$ is a glottal stop and is not pronounced)".

${ }^{67}$ See Haar 1925:48, 51; Paauw 1923:184-185; Damsté 1923:177. 
All these facts corroborate my presumption that the kain kumalo used in Sembiran and in other places in Bali are actually of Lombok origin, or at least that they have been manufactured in Bali under strong Lombok influence. Certainly, in common with checked cloths on a plain ground, they clearly follow the same basic design concept, which was probably wide-spread on both islands once upon a time.

\section{"Kain Sembiran" - A Label?}

Many Balinese textile collections include fabrics usually called "kain Sembiran "by museum experts, collectors, and dealers. ${ }^{68}$ We shall discuss this name later. These hip-wrappers have a basic design structure similar to the kain kumalo: a prominently decorated panel (kepala) between two lateral parts (badan) with narrow weft stripes of two or three shots each. Their colour combination is generally reduced to brick or rusty red, white and dark blue, or to rusty red, white, yellow and green, but it may be enriched with more colours and single metal threads. The much thinner, sometimes hardly visible warp threads are of white, red, green and blue shades. The decorated panel is usually more or less placed in the centre of the cloth; in the type with floral patterns (see below), it is often shifted sidewards to one end, and small bands repeat part of its central side borders at both ends. The length of these fabrics goes from 163 to $238 \mathrm{~cm}$; their width is relatively large (100

\footnotetext{
${ }^{68}$ Museum der Kulturen Basel: no. IIc 14954, from Lombok or Bali, collected by L. Langewis before 1956, nos. IIc 15389 and 15390, from Lombok, collected by L. Langewis before 1959, no. IIc 15969, from Batur region, collected by M.L.J. Lemaire before 1966 (Hauser-Schäublin, Nabholz-Kartaschoff and Ramseyer 1991:Ill. 1.3), no. IIc 17582, from Buleleng, collected by U. Ramseyer in Klungkung from a person from Singaraja before 1974
}

Collection Georges Breguet, Geneva: nos. Bali-1-018 and 019 (Breguet 2006: cat.no. 58 and 59)

Rautenstrauch-Joest-Museum Köln: no 24363, acquired in Buleleng by Thomann-Gillis 1907/1908 (Khan Majllis 1984:Kat. 341)

Wereldmuseum Rotterdam: nos. 25988, 25989, 25991, 49559, from Buleleng, collected by L.C. Heyting before 1924, no. 27821, from Nusa Penida, collected by E. Jacobson, before 1931, no. 60856, from Buleleng, acquired from J. Hartman, 1970s

Museum of Fine Arts Boston: no. 25.64 (no precise data at hand) Asian Civilisations Museum Singapore: one example with figurative design (inventory number not at hand), acquired from a dealer in Jakarta end of 1990s

National Gallery of Australia Canberra: nos. 1990.1266-1269, collected by Michael and Mary Abott, acquired by them from dealers in Bali before 1990; nos. 2000.846-847, former collection Robert Holmgren and Anita Spertus (original nos. I-828 and I-827), acquired by them from dealers in Bali in 1987

UCLA Fowler Museum of Cultural History Los Angeles (UCLA): no. X61.28, collected by Katharane Mershon in Bali, 1930es, no. LX7 4.279, collected by Miguel Covarrubis in Bali, 1930s

Collection Robert Holmgren and Anita Spertus, no I 936, acquired in Bali, 1980s

Private Collections in Germany and the US

This list is not exhaustive. 
to $108 \mathrm{~cm}$ for the ones with geometric patterns, 88 to 106 for the floral ones). All originals available for study were woven in one web, and were never composed of two webs sewn together. Thus, they must have been manufactured on a larger loom than the Sembiran loom described above.

There are two quite different types of decoration for the dominant kepala: The first group is characterized by a combination of weft ikat stripes and supplementary weft bands with geometrical motifs such as small diamonds, complicated rhomboid forms, crosses, arrow-heads, stars, stylised blossoms, etc. (Photo 16)-

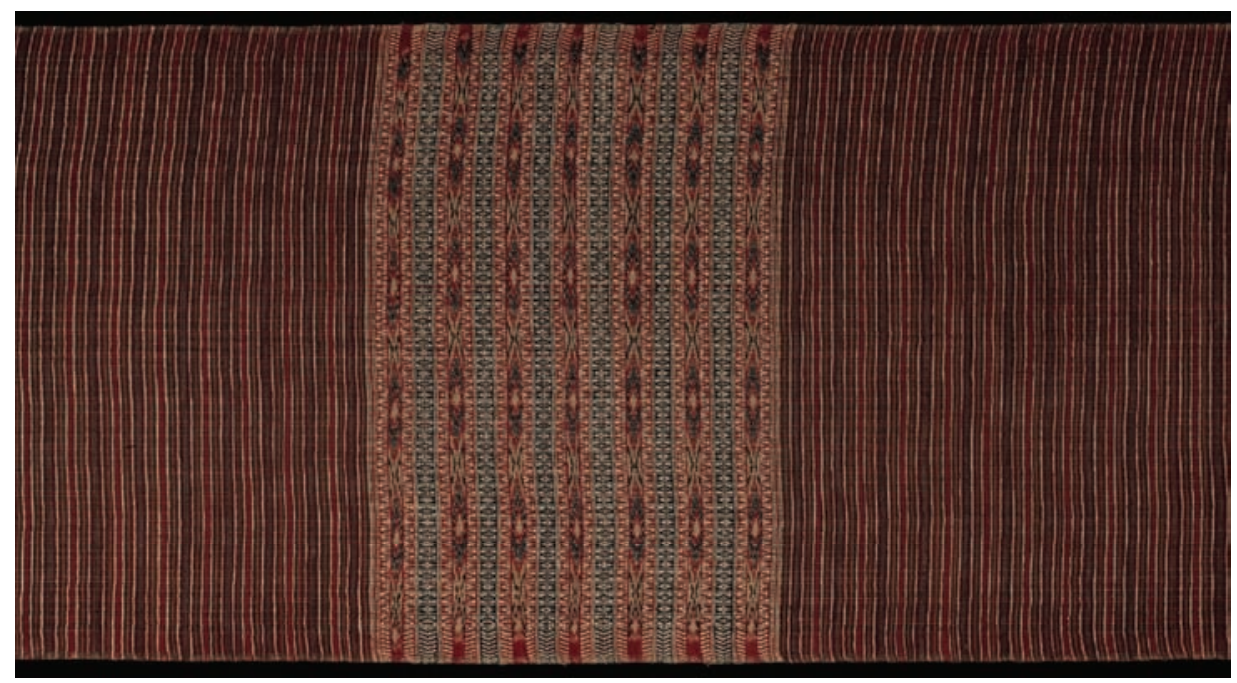

Photo 16: "Kain Sembiran" of geometric style with weft ikat stripes, Lombok. Museum der Kulturen Basel no. 15389. Acquired from L. Langewis 1960 (before in an old Dutch collection).

Some of the white-and-red, white-and-blue, or white-and-red-and-blue ikat designs with elongated lozenges and crosses are elaborated with greatest precision, whilst others appear quite blurred. We know only of one single example with anthropomorphic motifs, rows of small, stylized human figures in supplementary weft technique, placed in between the usual ikat stripes. ${ }^{69}$

The second group has no ikat decoration; its supplementary weft patterns are much more elaborate, and in an ornamental floral style (Photo 17).

They are slightly reminiscent of designs of courtly silk songket fabrics worked with gold or silver threads; as a matter of fact, they look like rough interpretations of the same design concept. They are formed of two opposite rows of elegant shrubs, framing a grid-like structure of lozenges with stylised blossoms, enclosed by two bands with artistically designed lozenge-like motifs.

${ }^{69}$ Collection of Asian Civilisations Museum Singapore (see note 68). 


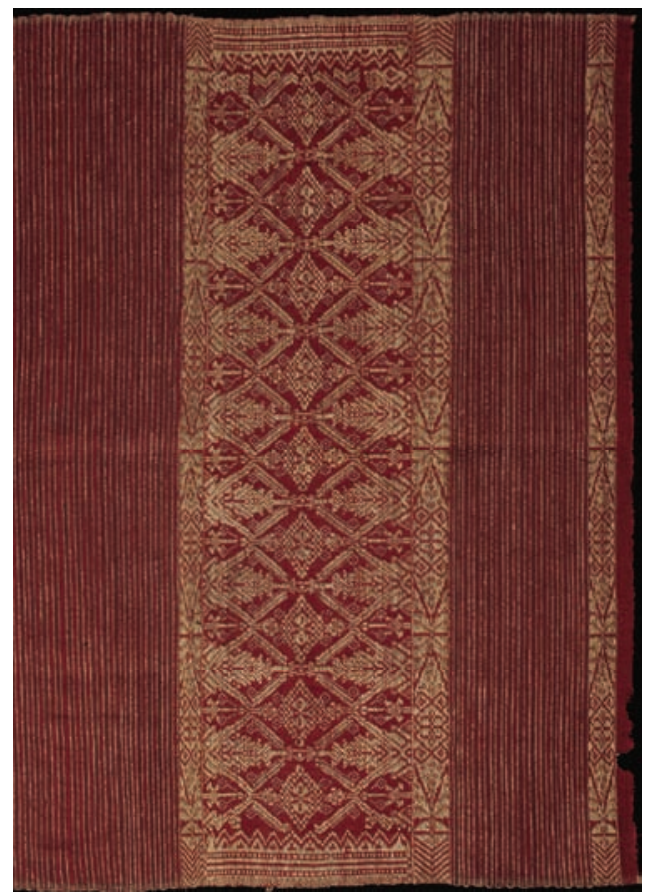

Photo 17: "Kain Sembiran" of floral style, Buleleng (Bali) or Lombok. Museum der Kulturen Basel no. IIc 17582. Collected by Urs Ramseyer, acquired in Klungkung from a person of Singaraja 1974.

It is striking that both groups show relatively few differences with respect to their basic design idea and patterns. Especially in the second group, the decoration of the central panel is practically always the same, with some minor variations. We are, therefore, inclined to believe that they might have been produced in two separate weaving centers, or at least have been influenced by two such dominant centers.

The most characteristic feature of these "kain Sembiran" is the use of a coarse metal thread as supplementary weft in the central panel or as single shots in the lateral parts. Narrow strips of paper, coated with gold leaf with quite a high content of silver are wrapped Z-wise around a rather thick core. This core is undyed, and was identified on many samples as ramie, Boehmeria nivea Gaudich (p.93). ${ }^{70}$ The wrapping is rather loose with intervals in between the windings through which the core is visible. The yarn is very brittle; often the golden paper strips are totally worn out, so that only the core remains intact. Elsewhere, the formerly shiny gold

\footnotetext{
${ }^{70}$ In one example, hemp (Cannabis sativa) was identified by the Koninklijk Instituut voor het Kunstpatrimonium, Brussels, 2003.
} 
leaf has corroded to grey or to a blackish colour, or is completely rubbed off; sometimes just tiny spots of metal stratum and remnants of a red or orange bolus are left on the remaining paper base.

This coarse gold thread also appears on narrow girdle-like cloths with supplementary weft designs which look like the stylised blossom patterns of "kain Sembiran". ${ }^{71}$ In ancient times, they were even used in Sembiran, as part of the wedding garb (pesaluk), as a breast cloth (anteng) when carrying offerings at festivals, or as a kind of scarf (panja selimbag) worn diagonally on the occasion of daba gatherings. ${ }^{72}$ This metal yarn is also to be found as decorative warp stripes in another girdle of very great age $(150 \text { years or more })^{73}$, in the Kintamani breast-cloth mentioned above (p.94), in the end parts of several shoulder-cloths collected in South Bali. ${ }^{74}$ And it appears again on rare examples of geringsing textiles, the end part patterns of which had been over-embroidered. ${ }^{75}$ Those geringsing were usually not used in Tenganan itself, but were gifts or tributes given away to royal courts like Klungkung $^{76}$, Karangasem or Buleleng, and were most probably enriched with gold thread embroidery there; one weaver in Tenganan remembered that this was a speciality of Buleleng.

In principle, metal yarn made of gilded paper strips wrapped around a white or yellow silk core is regarded as a typical Chinese material, but usually it is of much finer quality. ${ }^{77}$ According to Jasper en Pirngadie (1912:22-23), all metal threads used in Indonesia were imported. They were of two types, metal wire wrapped

${ }^{71}$ For instance Rijksmuseum voor Volkenkunde Leiden, no. 300.172, exhibited in the Paris World's Fair 1878; Museum der Kulturen no. IIc 2432, collected by Paul Wirz in Bali, before 1925; or National Gallery of Australia Canberra: nos. 1990.1270-1273, collected by Michael and Mary Abott, acquired from dealers in Bali before 1990.

${ }^{72}$ Personal communication from Brigitta Hauser-Schäublin, 2004.

${ }^{73}$ Collection Georges Breguet, Geneva: no. Bali-2-086, from a village of Balinese emigrants in Lampung, South Sumatra, who left Bali in the 1950s or 60s.

${ }^{74}$ Museum der Kulturen Basel, nos. 14076, 14098-14100.

75 Brigitte Majlis drew my attention to this fact.

${ }^{76}$ Breguet 2006: cat. 60.

${ }^{77}$ Many different techniques have been developed to produce elastic metal thread for weaving and embroidering:

hammered and cut strips of metal foil (Ancient Egypt, Persia); fine metal wire (India); cut strips of leather, parchment, animal gut coated with gold- or silver-leaf (Orient, Europe); cut strips of paper coated with gold- or silver-leaf (China); solid metal strips, or wire wound in spirals around a silk, linen or cotton core (India, Middle East, Europe); cut metal-coated strips of leather and animal gut wrapped around a core (Near East, Spain); cut metal-coated strips of paper wrapped around a core (China).

According to Jolly (2002:184) paper strips coated with gold leaf around a yellow silk core, or with silver leaf around a white one, were used in China and in Central Asia since as early as the $14^{\text {th }}$ century.

Metals used are basically gold, silver, copper, brass, or alloys. Metal strips and wires often have an extremely thin outer stratum of precious metal only. The coat of gold- or silverleaf is usually applied to the support with a layer of red or white bolus as an adhesive under it (Járó 1996:35-36; Peter 2006; Watt and Wardwell 1997:142, 150, 152, 188). 
around a core, most probably originating from India, and metal-coated paper strips wrapped around a core, from China. William Marsden's list of foreign goods in circulation in Sumatra in the 1770s (p.70) includes coarse silks and metallic thread from China (Guy 1998:68). The Minangkabau in Sumatra used both kinds in weaving, metallic strips as well as gilded paper strips, wrapped around a core (Summerfield 1999:203; Indictor 1999:226-231; Hanssen 2000:44-45), and used the expression benang Macao for metal thread. ${ }^{78}$

In Bali, gold thread was acquired through dealers from Singapore, as reported by Captain Chinkak in 1845 (p.93). Thanks to a French silk ribbon manufacturer, Isidore Hedde, we learn that in 1844, thread wrapped with gold-leaf coated paper strips imported from China was woven into "kaen sonquete" (kain songket) in a big Singapore workshop; he considered this yarn to be of much inferior quality than European gold thread (Salmon 2005:9). In Dutch colonial times, the high valued metal threads came from Singapore via Buleleng to Klungkung, on boats that had transported pigs from Buleleng to Singapore before. ${ }^{79}$ Not all of this paper-strip wrapped material is of such coarse quality as that used in "kain Sembiran". Fine silk songkets from the Puri Badung (Denpasar) from the end of the $19^{\text {th }}$ century are woven with extremely fine gold and silver threads with gold-leaf-coated paper strips wrapped around a silk core. ${ }^{80}$

One last typical technical detail has to be mentioned: quite often, single gold thread wefts in the lateral parts are accompanied by a white cotton thread in the same shot in order to increase their protruding effect. According to the labels of L.C. Heyting on several "kain Sembiran" in the Rotterdam collection, this is called renteng ${ }^{81}$; Sembiran weavers mentioned this term in connection with shouldercloths with gold thread from Lombok (Photo 18).

\footnotetext{
78 This points to the fact that they probably bought this material through traders from this important Portuguese trading post on the Southern coast of China. Indictor (1999:226227), however, maintains that benang Macao consists of solid metal strips wrapped around a core, and is thus not of Chinese, but rather of Indian, Persian or European origin, possibly traded through Macao. Diana Collins has suggested that this material was possibly produced in Kanton.

${ }^{79}$ Personal communication from Georges Breguet, 2006.

${ }^{80}$ Confiscated by the Dutch after the Puputan War of 1906 and now in the Rijksmuseum voor Volkenkunde in Leiden.

${ }^{81}$ According to Rens Heringa, the term renteng used in Java means "two or more in front or behind each other", which seems appropriate for the technique of entering two threads together in one shot.
} 


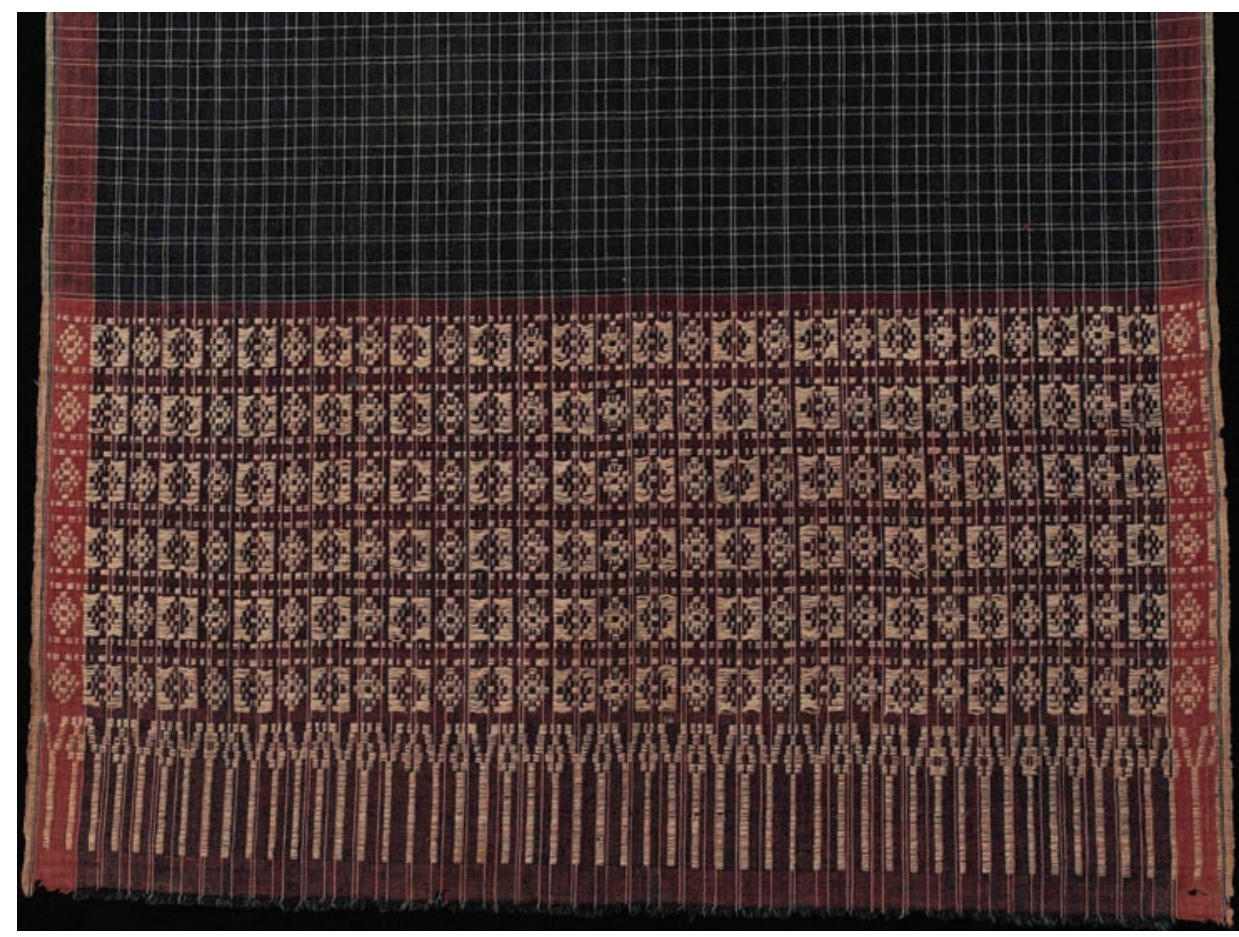

Photo 18: Ceremonial selendang, Lombok. Museum der Kulturen Basel no. IIc 15395. Acquired from L. Langewis 1960 (before in an old Dutch collection).

But where did this coarse gold thread with a ramie core come from? None of several competent experts has ever met with such a material, neither in Indonesia, nor in China, nor in Japan, nor elsewhere. Could it, eventually, have been manufactured locally as a cheaper substitute for the expensive imported material? There are good reasons to believe this. Compared to Chinese material, the thread's quality is quite poor. One could imagine that the local producers used imported gilded paper sheets which they cut up in narrow strips ${ }^{82}$ to wrap around the ramie core. Gold- and silver leaf had been imported from China, too, and Balinese craftsmen were actually familiar with processing gold-leaf on textiles (kain perada), leather and wood. Or was it from Lombok? Sembiran weavers took the gold thread in several shoulder-cloths collected in South Bali (see note 74), and also in a Lombok shoulder-cloth (Photo 18), to be typically Sasak and slem (see note 7), and mentioned at the same time Chinese traders in the village of Bondalem near Tejakula who were evidently specialized in selling such yarns. China, Bali, Lombok, or perhaps Sumatra? Stimulated by a remark made by Brigitte Majlis shortly before

${ }^{82}$ This is how they proceeded in China and Japan (Personal communication from Alan Kennedy, 2006). 
printing of this article, I discovered the same coarse gold thread with a ramie core on several very old ceremonial women's sarongs (tapis) and ship-cloth (palepai) from the region of Lampung in South Sumatra. This important fact opens up a new possible interpretation, which needs to be followed up in the future.

There is very little information available about what "kain Sembiran" were actually used for. Their size and basic design structure give us reason to assume that they were worn as hip-cloths on festive and ritual occasions. This is supported by the occasioned labels of L.C. Heyting on his collected samples (see note 68) on which he wrote "temple- en offerkleed".

As in the case of kain kumalo (p.91), it is doubtful whether the use of the two different types was gender-specific. Those decorated with floral motifs are generally smaller. One might infer that this type was rather worn by women - a asymmetrically placed kepala would be better suited to wrap the cloth around their body - whilst a centred arrangement might be preferred by men who knot their hipcloth more or less symmetrically. The weaver Ni Wayan Landri from Sembiran added that such fabrics could have been worn by baris perisi dancers. ${ }^{83}$

Let us state from the very beginning, that the denomination "kain Sembiran" never appears in connection with samples in old museum collections (Basel, Neuchâtel Köln, Rotterdam, Los Angeles); it was only mentioned for pieces collected from the 1970s onwards when collecting Indonesian textiles became extremely popular. None of the many "kain Sembiran" known to us was acquired in Sembiran itself. Some were said to come from Buleleng, others were purchased without any detailed information on provenance, some were said to come from Lombok, and we know of two Lombok dealers who offered such pieces of Lombok origin for sale. Weavers in the village unanimously stated that these fabrics were not manufactured in Sembiran. One of them assumed, it might be Sasak, another added that dealers from Buleleng were selling such fabrics and commented: "this is a very expensive cloth".

I suspect this kind of "fashion designation" was propagated relatively late by dealers. Stamping them with the provenance "Sembiran", which was considered a Bali Aga village made them more interesting for their clients and gave them a certain aura of mystery. ${ }^{84}$

\footnotetext{
83 According to Brigitta Hauser-Schäublin, different forms of ritual baris dances are still performed by men in Julah and in Sembiran on the occasion of temple festivals. They symbolize the eternal battle between Good and Evil. Nowadays the dancers' costumes only include relatively new fabrics. In the baris perisi the dancers represent particular kinds of soldiers (praejurit).

84 This may be compared with the once-maintained myth that all cepuk cloths came from Nusa Penida (many in fact are from Tabanan and Buleleng, see Hauser-Schäublin, Nabholz-Kartaschoff and Ramseyer 1991:114).
} 


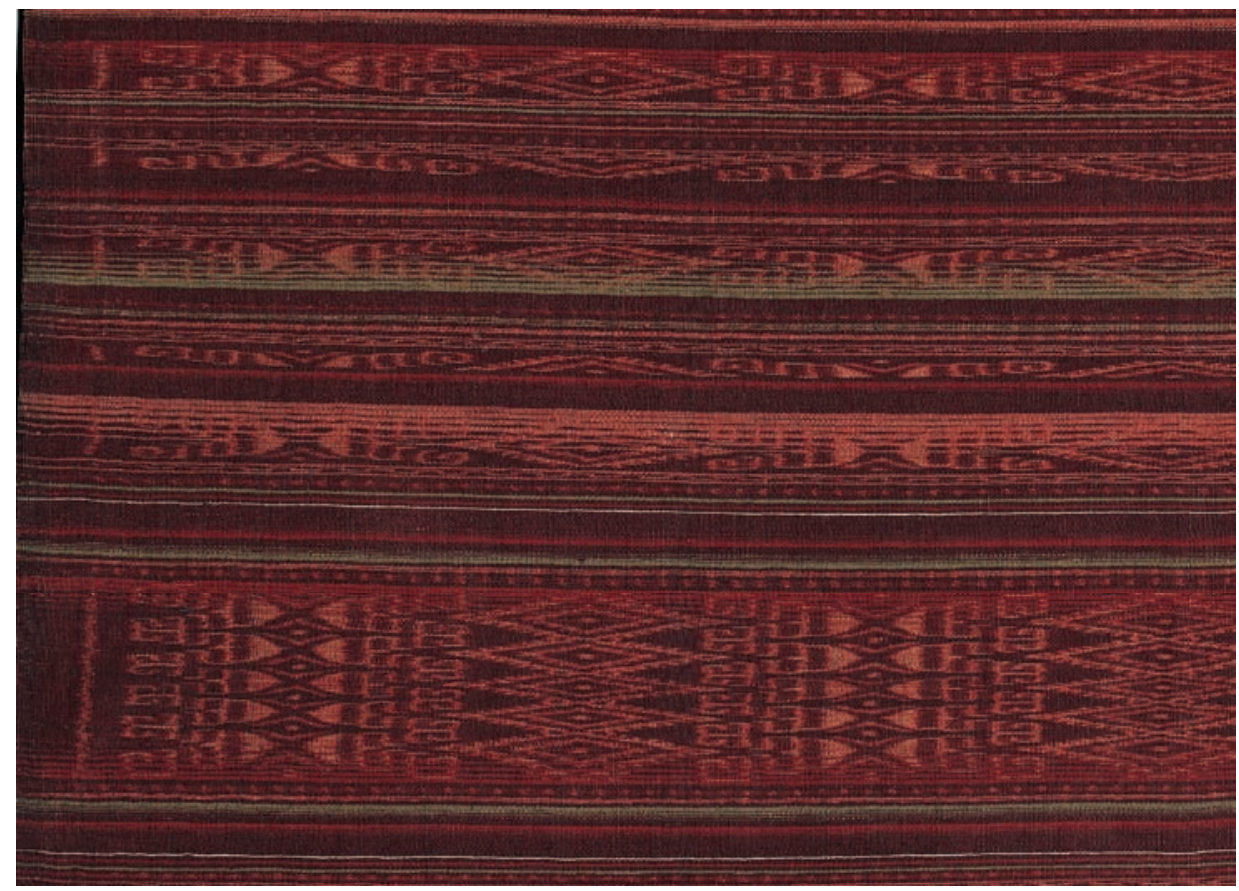

Photo 19: Anak néné (detail), North Lombok, Sembalun or East Lombok, Masbagik area. Museum der Kulturen Basel no. IIc 21383, 19th century, acquired from A. Flick 1997.

But where do they actually come from, Bali or Lombok?

Summing up all the data given on provenance for examples collected before the 1970 s and analyzing the different complementary information available, we find that a provenance from Lombok prevails for at least the first group. This corresponds to the fact that their designs have remarkable counterparts in Lombok textiles. Their supplementary weft decoration is very much like similar patterns on certain kain usap ${ }^{85}$ from Sasak in North Lombok, and in shoulder-cloths of the type illustrated (Photo 18), which by the way also shows the renteng effect (p.102).86

${ }^{85}$ Usap are small square ceremonial cloths with purely geometrical patterns, either repeated all-over or arranged in bands. They are used as ceremonial head-cloths for women, as ritual cover over betel chewing ingredients, and in life cycle rituals (Cederroth 1993:305, 311). For comparison see Museum der Kulturen Basel, nos. IIc 18846, 18848, 18853, and Rijksmuseum voor Volkenkunde Leiden, nos. 2407.230, 231, 252; for illustrations see for instance Maxwell 1990:Ill.246).

${ }^{86}$ Let us add that the weaver Ni Ketut Sri Ngentek from Sembiran identified this shoulder-cloth as Sasak (slem) and said that such fabrics were brought by Muslim Lombok traders over Padangbai up to her village. They could be used there by women on the occasion of temple festivals. 
As regards the anthropomorphic figures on one single "kain Sembiran" (note 69) which are not at all Balinese in style, there is a certain resemblance to human figures on musla or pesujutan fabrics ${ }^{87}$, also from North Lombok. And exactly the same type of weft ikat designs may be found in anak nene textiles (Photo 19), another kind of very rare old ritual cloth from the Sasak Wetu Telu in North and East Lombok. ${ }^{88}$

Sven Cederroth, the best expert for Sasak Wetu Telu in North Lombok never saw any cloth similar to "kain Sembiran" but suggested it could possibly come from Sembalun. Also the narrow fabrics with the same gold thread mentioned above would resemble similar girdles from the same area.

Finally, all these arguments convinced me that the "kain Sembiran" with geometrically patterned bands and weft ikat stripes might originate from Lombok.

The case is different for the second group. Their technical features and the design concept is similar to the first group, but the stylized floral patterns speak a totally different language, somewhat reminiscent of Buleleng silk songket fabrics. A letter dated June 6, 1924 from L.C. Heyting to J.W. Noyhuys, then director of the Rotterdam museum, might enlighten this question of provenance. ${ }^{89} \mathrm{He}$ wrote in connection with Balinese influence on ikat weaving in Lombok:

"Een plaatselijk onderzoek geeft dikwijls allerlei verrassingen. Zoo keek ik vreemd op toen ik te Pengastoelan, een der weefcentre van Boeleleng, opmerk.te, dat de patronen der ikatweefsels in zijde en halfiijde door Mohammedaansch-Balische vrouwen ontworpen worden, in hoofdraak althans, en ook het ikatten. Het eigenlijke weven geschiedt meest tegen betaling door Hindoe-Balische vrouwen, die goedkoopere arbeidskrachten zijn.

De Mohammedaansche Baliërs verhandelen deze ikatweefsels. Zoo koopt Fatima wel van deze weefsels en heeft dan van uit Singaradja (Boeleleng) de nitvoor plaats. Bij beschouwing van de patronen der te Singaradja gekochte inslag-ikats heeft man dus rekening

\footnotetext{
${ }^{87}$ Musla, or pesujutan, is a long, rectangular cotton cloth with supplementary weft patterns at both ends. It is one of the most sacred textiles of the Sasak, used by Muslim religious leaders (kiyai) in the mosque, and also by a bridegroom during the wedding ritual (Cederroth 1993:305-306, fig.7). For comparison see Museum der Kulturen Basel, no. IIc 20328; see for instance Khan Majlis 1991:168, Ill.149; Maxwell 1990:Ill.184.

${ }^{88}$ Haar 1925:74; Khan Majlis 1984:78; Khan Majlis 1991:168, Ill.151; Maxwell 1990:165, Ill.99.

${ }^{89}$ I am grateful to Linda Hanssen for having discovered this letter for me in the archives of the Wereldmuseum Rotterdam.
} 
te bouden met het feit, dat Mohammedaansche ideën invloed gehad kunnen bebben op het ontstaan der patronen, en dat ze niet ziver Hindoe-Balisch behoeven te zijn. ${ }^{90}$

As the quotation above shows, Heyting was himself surprised to encounter professional weaving workshops in Buleleng, for example in Pengastulan ${ }^{91}$, where Muslim-Balinese women created designs for ikat fabrics, which showed Muslim (Lombok?) influence. Their products were executed on the loom by cheap-labour Hindu-Balinese women, and traded through Muslim-Balinese traders to Buleleng, and maybe to other places. Did they also possibly create other kind of textiles, maybe among them these floral "kain Sembiran", quite a number of which Heyting had acquired for the Rotterdam museum in Buleleng? This also supports my opinion that such wide cloths could not have been woven on simple village looms, and had possibly been manufactured in some specialized weaving centre (see p.75, p.100). Such Muslim-Balinese workshops might be compared to the famous Chinese-Javanese and Dutch-Javanese batik centres on the North coast of Java, which, in the last quarter of the $19^{\text {th }}$ century, created patterns strongly marked by European and Chinese influence (Khan Majlis 1991:117, 122).

Most "kain Sembiran" are attributed to the second half of the 19th century, maybe even earlier. One narrow cloth with the same supplementary weft design (note 71) is known to have been exhibited in the 1878 Paris World's Fair. Early dating also seems to be indicated by the harmonious colour scheme. The obvious lack of gaudy hues suggests that no synthetic dyes - which were already quite widespread at the beginning of the $20^{\text {th }}$ century - were used for them.

To sum up, we come to the conclusion that so-called "kain Sembiran" were not manufactured in the village of Sembiran. The first group with geometrical supplementary weft and weft ikat patterns is most probably of Lombok origin. As to fabrics of the second group with floral design, we suggest that they might have been products from Muslim-Balinese workshops in North Bali.

\footnotetext{
90 "Research on the spot often brings all kinds of surprises. Thus, I was very astonished, when I observed in Pengastulan, in one of the weaving centers of Buleleng, that MuslimBalinese women designed patterns for silk and mixed silk ikat cloths, and did also most of the ikat dyeing. The weaving itself was realized against salary by cheap-labour HinduBalinese women. Muslim-Balinese traders sell these cloths. Thus, when Fatima buys such textiles, she thinks they originate from Singaraja (Buleleng). When looking at designs of weft ikats acquired in Singaraja, one therefore has to bear in mind, that their creation may have been influenced by Muslim ideas, and that they do not necessarily have to be pure Hindu-Balinese" (Translated by M.L.Nabholz-Kartaschoff).

${ }^{91}$ Pengastulan is situated between Seririt and Bubunan, west of Singaraja.
} 


\section{Parba Cili - A Lamak-Style Hanging}

The extent to which the designation "Sembiran" has become a token for interesting textiles of archaic look - expensive ones - will be demonstrated by a unique hanging (Photo 20) said to originate from Sembiran. ${ }^{92}$

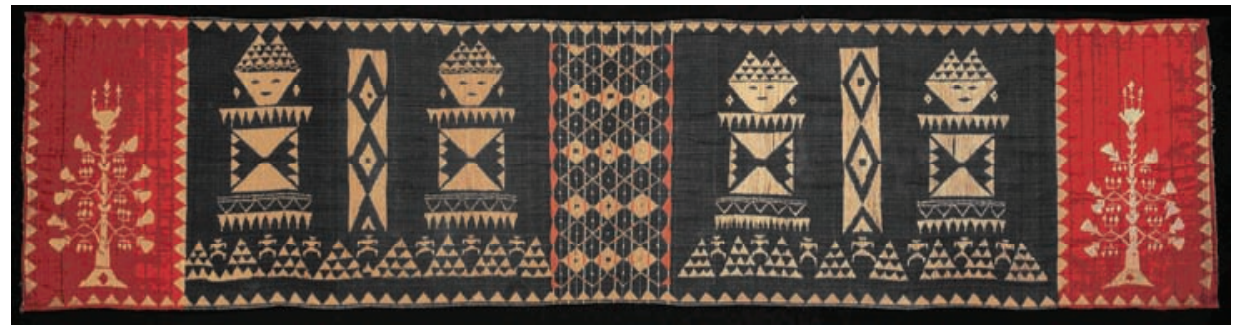

Photo 20: Lamak-style hanging (parba cili), Bali. Museum der Kulturen no. IIc 20290. Acquired from a Balinese dealer 1988.

It fascinates its viewer with its huge format (height $65 \mathrm{~cm}$, width $260 \mathrm{~cm}$ ) and its attractive patterns: four large female cili figures above rows of mountain-like patterns and small anthropomorphic representations on a dark indigo blue base, flanked by two flowering trees on a red background. Each pair of cili is separated by a rectangle with lozenge motifs, while the centre is formed by a grid with smaller diamonds.

At first glance, the style of the representation has much in common with designs on lamak decorations. ${ }^{93}$ These are elaborate constructions of different lengths, fashioned of white and green palm leaves (Photo 21), which are joined with little bamboo pins (jejaitan, from Balinese jait, "to sew").

They are created by women as ephemeral ritual adornments for altars or shrines, or as underlays for offerings. These vertical runners are always quite narrow, and may vary in length from about $30 \mathrm{~cm}$ up to more than 10 metres, when they serve as huge decorations at New Year or important temple festivals. There exist innumerable regional variations, but invariably present are a number of motifs replete with symbolic meaning: The sacred mountain Gunung Agung is the representation on earth of the cosmic Mount Mahameru, linking the three spheres as an axis.

\footnotetext{
92 No. IIc 20290, Museum der Kulturen Basel, acquired from a Balinese dealer in 1988.

93 See Brinkgreve 1992; Brinkgreve 1993; Langewis 1956; Pelras 1967.
} 


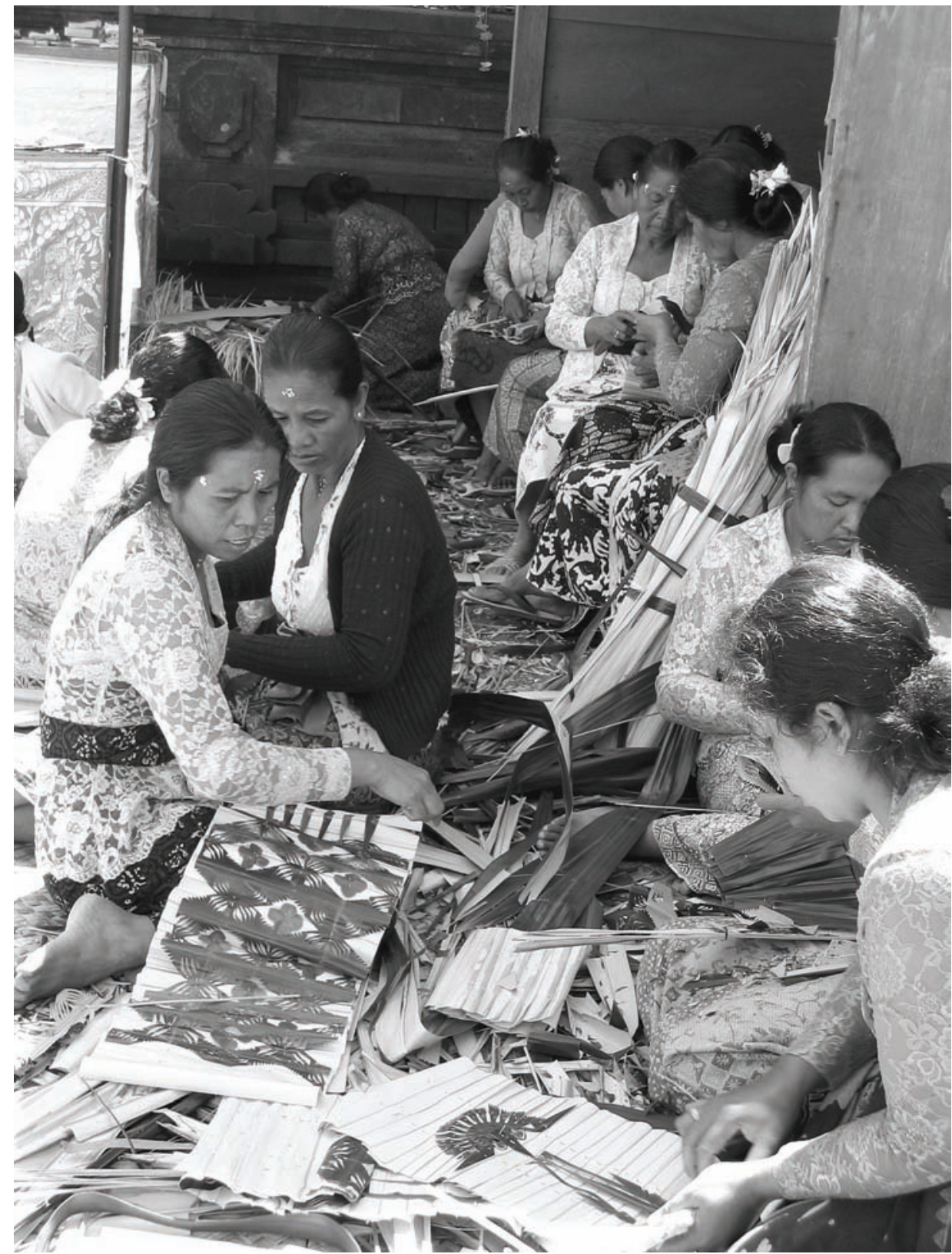

Photo 21: Women preparing „sewn“ lamak from fresh palm leaves for a festival at Batur Temple. 
The flowering tree, or Tree of Life, unites all living creatures, flourishing vegetation and wild life. The stylised female figure with her typical fan-shaped headdress, cili or deling, is an expression of human life and fertility, and may be sometimes associated with Dewi Sri, the rice goddess, who stands for fertility, prosperity and wealth. The sun and moon also appear, which are part of the upper world and bestow fertility on earth. The stylised geometric patterns are related to the base of the world, or the underworld.

The motifs are always placed vertically in a certain sequence that expresses symbolically a path or a bridge between heaven and earth and, in this way, the general Balinese view that the world or the universe is vertically ordered in underworld, middle world and upperworld. On small lamak, the representational elements are always placed at the top, the geometrical ones at the bottom. On large samples, these different elements may alternate, but the geometrical ones have implicitly to appear in the lower field. A lamak may be compared by the Balinese to a textile that is said to be the "clothing" of a shrine, dressed up for a festive occasion.

Actually, there exist a relatively small number of permanent lamak made of cloth instead of palm leaf. ${ }^{94}$ They are usually worked on blue, black or red cotton cloth with fine white stripes in a very special weaving technique. To realize the pattern, groups of thick undyed yarn bundles are inserted during the weaving process and led in parallel lines to the warp threads floating on the reverse side. Only a small number of motifs, like the sun and moon, are embroidered. ${ }^{95}$ According to Brinkgreve (1993:144, note 4) some examples were never ritually used, but "already in the thirties they might have been made especially to sell at art-exhibitions" to interested foreigners. ${ }^{96}$ As true lamak are extremely rare and much in demand, "art shops in Bali ask exorbitant prices for the few pieces they have in their possession, or they try to sell recently made embroidered copies" (Brinkgreve 1993:135).

Let us come back to the hanging in question:

The cotton base is most probably a complete web intended to be cut and sewn into a hip-cloth of the kain kumalo type; its external lateral parts had just been cut off. In fact, such full lengths were often stored away to be made up into a festive dress on a later occasion. ${ }^{97}$ The design is embroidered in quite a coarse way with a very thick ramie yarn ${ }^{98}$; knots are visible on the reverse side. The running stitches

\footnotetext{
${ }_{94}$ Brinkgreve 1992:135-136; Brinkgreve 1993:135 and note 2; Langewis 1956; Pelras 1967. ${ }^{95}$ Langewis 1956:32-33; Pelras 1967:257-264. According to Pelras (1957:259-261), this technique was invented by a weaver in Kesiman, Badung district.

${ }^{96}$ A typical example is the lamak no. 23937 in the Museum Nasional, Jakarta (Hardiati and ter Keurs 2005:143, 145). It was acquired by Engineer T.A. Resink in the 1930s in Bali, and sold to the Jakarta museum in 1941 (personal communication from Francine Brinkgreve, 2006).

${ }_{97}$ The Museum der Kulturen Basel owns an uncut web of this type with a total length of $328 \mathrm{~cm}$ intended to be cut and sewn into a kain kumalo (no. IIc 14028).

${ }^{98}$ Confirmed by analysis of the Koninklijk Instituut voor het Kunstpatrimonium, Brussel, 2003.
} 
imitate woven warp floatings; however the threads only run in the direction of the warp in the rows of triangles along the selvages, whilst all other patterns are embroidered in the direction of the weft, or are executed, as in the case of the flowering trees, in oblique stitches.

The former owner designated the hanging as a parba cili, ${ }^{99}$ used as a decoration on the occasion of tooth filings or ceremonies in honor of the rice goddess Dewi Sri when it would be suspended in a rice granary. He firmly maintained that it was made and used in Sembiran although rice cultivation in Sembiran has long been completely abandoned (see Hauser-Schäublin this volume), and rice granaries (jinang) have disappeared too. However, there still exists a shrine in the form of a jinang in the Pura Desa which has replaced a bigger one pulled down in 1959/60, and where a ceremony for Dewi Sri is performed every new moon Tilem Sadha. ${ }^{100}$ The weaver Ni Wayan Landri had never ever seen such a hanging in Sembiran, but she spontaneously associated its design with a kind of palm leaf lamak, locally called gelebegan-grantangan. It was used in ancient times in the rice fields to decorate a small altar, nini, where rituals were performed at the beginning (pinta gede) and the middle (pinta nengabin) of the harvest. ${ }^{101}$

Thus, there are several reasons to believe that this hanging was neither manufactured nor used in Sembiran, nor that it had served ritual purposes. Its horizontal shape is unparalleled, and its embroidery technique imitates in a rather crude way the rare weaving technique of genuine textile lamak. Above all, the style of combining the individual motifs arouses some suspicion. They are not arranged in the conventional order replete with symbolic meaning (p.110), but seem to float in an empty space, without meaningful relation to each other. Thus, for instance, the stylised geometric patterns that represent the base of the world are set somewhat randomly in between the cili figures.

Discussing these facts with Francine Brinkgreve and David Stuart-Fox, who are today the leading experts in this matter, we came to the common conclusion, that this astounding hanging was either an inspired creation of the 1930s intended to be sold to interested collectors (p.110), or that it is simply a recent fake for those gullible customers that are so keen to acquire authentic lamak textiles, indeed any textiles that were said to originate from the famous village of Sembiran.

\section{Summary}

We have shown in this chapter that the village of Sembiran produced, and still is producing, hand-woven cotton cloths, which are used as traditional festive garb by

\footnotetext{
${ }^{99}$ A parba is the wooden back wall of an open building (bale), which sometimes is embellished with paintings.

100 Personal communication from I Wayan Partheyasa, kelian desa of Sembiran, 1988.

${ }^{101}$ Personal communication from Brigitta Hauser-Schäublin, 1999.
} 
the group of unmarried girls and women and by brides and bridegrooms. They were also manufactured for villages outside Sembiran. Cultivation of cotton and weaving have been important home crafts since ancient times.

The textile traditions of Sembiran have undergone foreign influences and have integrated fabrics from outside the village; some of them presumably originate from Lombok. One typical case is represented by hip-cloths called kain kumalo, which are particularly interesting in terms of the raw materials used and their design.

Checked cloths with fine white lines on a plain ground obviously represent remnants of a common elementary design tradition, which probably was widely dispersed on both islands once upon a time.

So-called "kain Sembiran" textiles have been thoroughly investigated with regard to raw materials used, technical aspects and patterns. This led to the final conclusion that they were not manufactured in Sembiran, but either in Lombok or in some Muslim-Balinese workshop in North Bali.

The connotation "Sembiran" seems to have been propagated by antique dealers at a relatively late date since the 1970s in order to increase collectors' interest in these textiles by attributing them to a village that once had unjustly been seen as an isolated and pure "Bali Aga" community. Thus it is not by accident that this label was also given to a particularly decorative hanging, which turned out to be a creative re-interpretation for sale to foreigners in the 1930 s, or perhaps a recent fake.

\section{References}

Anandakusuma, Sri Reshi

1986 Kamus Bahasa Bali: Bali-Indonesia, Indonesia-Bali. Graha Pengajaran: Kayumas.

Bally, Walter

1957 Ramie. Ciba Rundschau 132: 1-31.

Bloemen Waanders, F.G. van

1882 De Rameh. 'S-Gravenhage: H.C. Susan C.Hzn.

Böhmer, Harald

2002 Kökboya. Naturfarben und Textilien. Ganderkesel: Remhöb-Verlag Dr. Harald Böhmer.

Bolland, Rita

1971 A Comparison between the Looms Used in Bali and Lombok for Weaving Sacred Cloths. Tropical Man 4: 171-182.

Bolland, Rita, and A. Polak

1971 Manufacture and Use of Some Sacred Woven Fabrics in a North Lombok Community. Tropical Man 4: 149-170. 
Breguet, George

2006 La fibre des ancêtres. Trésors textiles d'Indonésie de la collection Georges Breguet. Genève: Musée d'Ethnographie.

Brinkgreve, Francine

1992 Offerings. The Ritual Art of Bali. Sanur: Image Network Indonesia.

Brinkgreve, Francine

1993 The Woven Balinese Lamak Reconsidered. In: Nabholz-Kartaschoff, M.L.; R. Barnes and D. Stuart-Fox (eds.): Weaving Patterns of Life. Indonesian Textile Symposium 1991; pp. 135-152. Basel: Museum of Ethnography.

Bühler, Alfred

1948 Primitive Dyeing Methods. Ciba Review 68: 2485-2500.

Cederroth, Sven

1993 The Role of Sacred Cloths in the Wetu Telu Cosmology of Bayan. In: NabholzKartaschoff, M.L.; R. Barnes and D. Stuart-Fox (eds.): Weaving Patterns of Life. Indonesian Textile Symposium 1991; pp. 305-320. Basel: Museum of Ethnography.

Damsté, H.T.

1923 Heilige Weefsels op Lombok. Tijdschrift voor Indische Taal-, Land- en Volkenkunde 65: 176-183.

Eck, R. van

1875 Schets van het Eiland Lombok. Tidschrift voor Indische Taal- Land- en Volkenkunde 22: 311-363.

1880 Schetsen van het Eiland Bali. Tidschrift voor Nederlandsch Indie 9: 1-39.

Fraser, J.J.

1908 De Weefkunst in de Afdeeling Boeleleng (Bali). Tijdschrift voor het Binnenlandbestuur 35: 324-333.

Gittinger, M. and H. Leedom Lefferts, Jr.

1992 Textiles and the Tai Experience in Southeast Asia. Washington, D.C.: The Textile Museum.

Graves, Elizabeth and Charnvit Kaset-Siri

1969 A Nineteenth-century Siamese Account of Bali with Introduction and Notes. Indonesia 7 (April): 77-122.

Guy, John

1998. Woven Cargoes. Indian Textiles in the East. London: Thames and Hudson.

Haar, J.C.C.

1925 De Heilige Weefsels van de „Waktoe-Teloe“ op Oost-Lombok. Tijdschrift voor Indische Taal-, Land- en Volkenkunde 65: 38-89.

Hanssen, Linda

2000 Gouddraad in Indonesische Weefsels. De Gouddraad-Doeken van de Minangkabau van West-Sumatra. In: Textieldag gehouden op 17 April 1997; pp. 32-47. Utrecht: Museum Catharijneconvent. 
Hardiati, Endang Sri and Pieter ter Keurs

2005 Indonesia. The Discovery of the Past. Amsterdam: KIT Publishers.

Hauser-Schäublin, Brigitta

2003 The Pre-Colonial Balinese State Reconsidered. A Critical Evaluation of Theories on the Relationship between Irrigation, the State, and Ritual. Current Anthropology 44: 153-181.

2004 "Bali Aga" and Islam: Ethnicity, Ritual Practice, and "Old-Balinese" as an Anthropological Construct. Indonesia 77 (April): 27-55.

2005 Temple and King: Resource Management, Rituals and Redistribution in Early Bali. The Journal of the Royal Anthropological Institute 11: 747-771.

Hauser-Schäublin, Brigitta, Marie-Louise Nabholz-Kartaschoff, and Urs Ramseyer 1991 Textiles in Bali. Berkely-Singapore: Periplus Editions.

Heyd, Wilhelm

1936 Histoire du Commerce du Levant au Moyen-Age. Leipzig: Harrassowitz.

Heyne, K.

1927 De Nuttige Planten van Nederlandsch Indie. Leiden: Brill.

Indictor, Norman

1999 Metallic Threads in Minangkabau Textiles. In: Summerfield, Anne; John Summerfield (eds.): Walk in Splendor: Ceremonial Dress and the Minangkabau; pp. 225-238. Los Angeles, Calif.: UCLA Fowler Museum of Cultural History.

Járó, Márta

1996 Quick Determination of the Manufacturing Technique of Metal Threads on Museum Textiles before Treatment and Review of the Methods Used for Their Cleaning. Unpublished Lecture, 2. Ehemaligentreffen der Abegg-Stiftung - Referate der Tagung 1./2. Nov. 1996. Riggisberg: Abbegg-Stiftung.

Jasper, J.E., en Mas Pirngadie

1912 De Inlandsche Kunstnijverheid in Nederlandsch Indië, Vol. II. Het Weefkunst. 'S-Gravenhage: Mouton.

Jolly, Anna

2002 Naturalismus. Seidengewebe des 18. Jahrhunderts. Riggisberg: Abegg-Stiftung.

Junghuhn, Franz W.

1842-54 Java. Leipzig: Arnold.

Kajitani, Nobuko

1980 Traditional Dyes in Indonesia. In: Gittinger, M. (ed.): Indonesian Textiles. Irene Emery Roundtable on Museum Textiles, 1979 Proceedings; pp. 305-325. Washington, D.C.: Textile Museum.

Khan Majlis, Brigitte

1984 Indonesische Textilien. Wege zu Göttern und Ahnen. Krefeld: Deutsches Textilmuseum.

1991 Gewebte Botschaften - Indonesische Traditionen im Wandel. Woven Messages Indonesian Textile Tradition in Course of Time. Hildesheim: Roemer-Museum. 
Korn, Victor E.

1932 Het Adatrecht van Bali. 'S-Gravenhage: G. Naeff.

Langewis, Laurens

1956 A Woven Balinese Lamak. In: Galestin, Th.P.; L. Langewis and R. Bolland: Lamak and Malat in Bali and a Sumba Loom; pp. 44-56. Amsterdam: Royal Tropical Institute.

Maxwell, Robyn

1990 Textiles of Southeast Asia. Tradition, Trade and Transformation. Melbourne: Oxford University Press.

Mohanty, Bijoy Chandra

1987 Natural Dyeing Processes of India. Ahmedabad: Calico Museum of Textiles.

Nevermann, Hans

1938 Die indo-ozeanische Weberei. Hamburg: Kommissionsverlag Friederichsen, de Gruyter \& Co.

Paauw, J.

1923 De Kekombong Umbaq (Heilige Draagdoek) in het Gebruik bij de Sasaks van Oost-Lombok. Tijdschrift voor Indische Taal-, Land- en Volkenkunde 65: 184201.

Pelras, Christian

1967 Lamak et Tissus Sacrés de Bali. Objets et Mondes 7, 4: 255-278.

Peter, Michael

2006 Metallfäden. Unpublished Texts of the Exhibition „Gewebtes Gold - Metallfäden in der Textilkunst“", 30.04.-12.11.2006. Riggisberg: Abegg-Stiftung.

Raffles, Thomas Stamford

1817 The History of Java. London, 1817. Reprint 1988. Singapore: Oxford University Press.

Ramseyer, Urs

1984 Clothing, Ritual and Society in Tenganan Pegeringsingan (Bali). Verhandlungen der Naturforschenden Gesellschaft in Basel 95: 191-241.

Reuter, Thomas

2002 Custodians of the Sacred Mountains. Honolulu: University of Hawaii Press.

Riemenschneider, Christian

2004 „Die Lebenden hierhin, die Toten dorthin“: Konstituierung und Transformation der Person in Lebenszyklusriten in Sembiran (Bali). Unpublished M.A. Thesis, Universität Göttingen: Institut für Ethnologie.

Riemenschneider, Christian, and Brigitta Hauser-Schäublin

2006 “...Yang Hidup di sini, Yang Mati di sana“: Upacara Lingkaran Hidup di Desa Sembiran, Bali (Indonesia). Göttinger Studien zur Ethnologie, Bd. 15. Berlin: LIT. 
Salmon, Claudine

2005 La sériciculture à Sumatra Nord. De l'histoire à la légende de job. Archipel 70, Paris: 239-260.

[n.d.] La Mission de Théodose de Lagrené et les Enquêtes sur les Textiles d'Insulinde. In: Chuanhui, Mau (in print) (ed.): Les Échanges Franco-Chinois au XIXe siècle. Colloque des 3 et 4 juin 2004. Paris.

Schot, Christa

2001 Unpublished Fieldnotes. Research on Women's Organizations in Sembiran (Bali). Archives Institut für Ethnologie der Universität Göttingen.

Schrieke, Bertram Johannes Otto

1955 The Shifts in Political and Economic Power in the Indonesian Archipelago in the Sixteenth and Seventeenth Century. In: ders.: Indonesian Sociological Studies; pp. 1-82. The Hague, Bandung: W. van Hoeve Ltd.

\section{Stuart-Fox, David}

1993 Textiles in Ancient Bali. In: Nabholz-Kartaschoff, M.L., R. Barnes and D. StuartFox (eds.): Weaving Patterns of Life. Indonesian Textile Symposium 1991; pp. 85-98. Basel: Museum of Ethnography.

Sumaryoto, Woro Aryandini

1991 Textiles in Javanese Texts. In: Nabholz-Kartaschoff, M.L., R. Barnes and D.

Stuart-Fox (eds.): Weaving Patterns of Life. Indonesian Textile Symposium 1991; pp. 31-49. Basel: Museum of Ethnography.

Summerfield, John

1999 Fibers and Patterning Techniques. In: Summerfield, Anne; John Summerfield (eds.): Walk in Splendor: Ceremonial dress and the Minangkabau; pp. 201-224. Los Angeles, Calif.: UCLA Fowler Museum of Cultural History.

Tuuk, H.N. van der

1897-1912 Kawi-Balineesch-Nederlandsch Woordenboek. Batavia: Landsdrukkerij.

Vickers, Adrian

1987 Hinduism and Islam in Indonesia: Bali and the Pasisir World. Indonesia 44: 3158.

Warna, I Wayan

1978 Kamus Bali-Indonesia. Denpasar: Dinas Pengajaran Propinsi Daerah Tingkat Bali.

Watt, James C.Y. and Anne E. Wardwell

1997. When Silk was Gold. Central Asian and Chinese Textiles. New York: The Metropolitan Museum of Art. 
Wirz, Paul

1931 Die magischen Gewebe von Bali und Lombok. Jahrbuch des Bernischen Historischen Museums in Bern, Vol. 9; pp. 39-49. Bern: Wyss.

Yoshimoto, Shinobu

1988 Kain perada: Hirayama Collection: The Gold-Printed Textiles of Indonesia. [s.l.]:

Kodansha. 



\title{
Sanggah Dawa in the Life of Pacung Community
}

\author{
I Wayan Patera
}

\section{Introduction}

Pacung village, Tejakula District, Buleleng Regency, is one of the old villages located in the northern part of Bali near Bangkah, Sembiran and Julah. With its specific traditions and large amount of cultural relicts still considered sacred by the community, Pacung, classified as a Bali Aga village, has been an object of research from the $1^{\text {th }}$ to the $21^{\text {st }}$ century (see Ardika, Setiawan and Rochtri, Suastika, Drawatik, Hauser-Schäublin this volume).

The findings of the researches so far carried out suggest that Pacung and the other Bali Aga villages located in the eastern part of Buleleng regency are sites that have been settled since the pre-historic era. This can be proved by the findings of Palaeolithic artefacts and pottery sherds, some local and others made in China and India. Human skeletons with grave goods have also been found, providing evidence of the belief in a life after death and worship of ancestors.

The findings of foreign pottery sherds, such as the ornamented Indian one, show that Pacung and its surroundings were settlement sites and in touch with the outside world already 2000 years ago (see Ardika this volume). The quality of the rouletted pottery of Indian origin found at Pacung was good. It is said to have come from Arikamedu in South India at the beginning of the first century AD.

The arrival of Hindu culture did not necessarily mean the extinction of the old culture or Bali Aga, whose essence is the belief in the power of nature and the 
ancestors' souls (Ardana 1986:15). Nevertheless, apart from grave goods we do not know much about the contents of pre-Hindu religion. However, there are traces of religious beliefs and practices left that differ from Indian Hinduism, such as ancestor worship. We therefore can assume that ancestor worship in Bali is a survival of pre-Hindu religion. As Koentjaraningrat stated, religion consists of five elements: the system of belief, religious emotion, a system of sites, ceremonial and ritual tools and religious worship (1980:80). This applies to all religions including ancestor worship and the worship of the natural powers (Hendropuspito 1983:34).

This article focuses on one special feature of ancestor worship in Pacung as still performed today. The data were collected through library research, survey and narrative interviews in Pacung village, and analysis of forms. A contextual interpretation will then be made, resulting in a description of the function and meaning of sanggah dawa.

One of the most interesting things in the socio-cultural life of the Pacung community, especially in their religious life, is the holy shrine (pelinggib) called sanggah dawa. There are only 14 families (out of 238 in 2007) who have such a shrine in their household temple. Most of the villagers possess a household temple with shrines that are similar to those in other parts of the island.

\section{Function and Meaning of Sanggah Dawa}

The expression sanggah dawa is derived from two words, sanggah and dawa. Sanggah refers to a group of holy buildings belonging to a family coming from the same ancestors ( $s a=$ one, angga $=$ body, sanggah = belonging to the same ancestors); dawa means 'long'. sanggah dawa is therefore the name given to a form of holy building belonging to one family. It is narrow high and long (see Photo 1). The structure of sanggah dawa consists of three parts: the foot, the body and the top with the niches (rong) including the roof. The building is $170 \mathrm{~cm}$ high, the foot is $30 \mathrm{~cm}$ thick, the body is $20 \mathrm{~cm}$ thick and it is $170 \mathrm{~cm}$ wide. In the upper part there are at least 18 niches, each of which is $20 \mathrm{~cm}$ high, $15 \mathrm{~cm}$ wide and $20 \mathrm{~cm}$ thick. It is the length of the building that probably leads to the name sanggah dawa. The building materials used for building sanggah dawa are bricks, and today also concrete and wood. Formerly, such structures were made entirely of bamboo. 


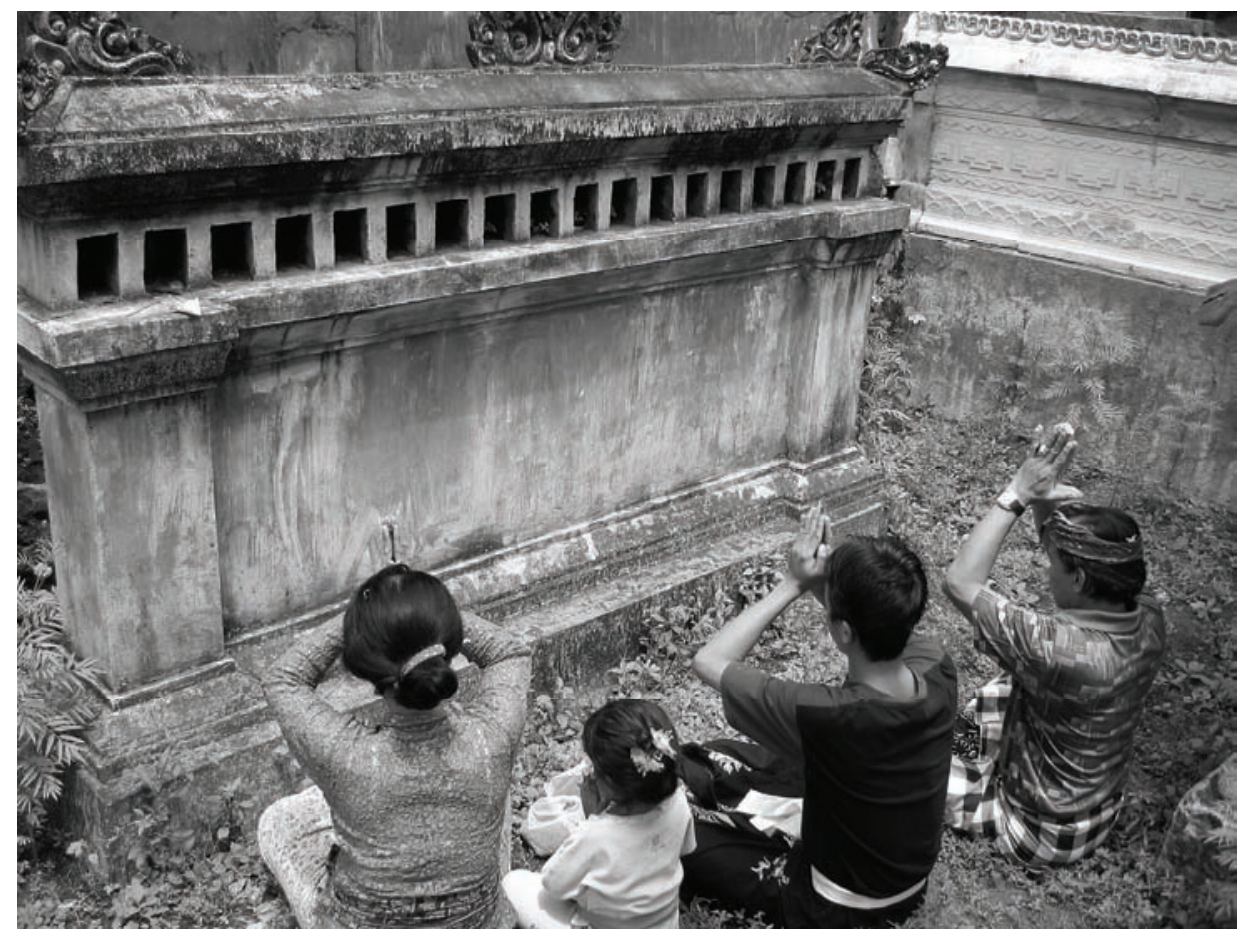

Photo 1: Worshipping in front of a sanggah dawa made of red bricks and covered with concrete; note the 18 niches. Photo: Brigitta Hauser-Schäublin 2007.

Based on information provided by I Nyoman Tisna, a well-known woodcarver and architect, sanggah dawa is the main structure of a family temple (sanggah). I Nyoman Tisna is a member of the Bujangga-Clan (Bujangga-Waisnawa). Seven generations ago, the forefather of Nyoman Tisna fled from Pintu village, which today no longer exists (see Hauser-Schäublin this volume), to Pacung and settled there. Pintu village was at that time attacked by "wild animals of the bush" probably a metaphor for enemies - and completely wiped out. Nyoman Tisna's ancestor escaped the killings, together with an elder brother who sought refugee in Sembiran and settled there. Still today, the descendants of these refugees in Sembiran and Pacung are closely related. Today, there are four Bujangga households in Pacung and each has its own sanggah dawa. Since members of other clans in Pacung also have sanggah dawa, we can assume that this type of shrine is more typical of Pacung village than of a single clan such as the Bujangga. It needs to be pointed out that the descendants of Bali Mula, or Aboriginal Balinese, in Pacung do not have a sanggah dawa in their household temple.

The specific feature of sanggah dawa is that it displays at least 18 niches. In addition, Nyoman also stated that the existence of the 18 niches cannot be separated 
from the belief system of the local community, that is, they believe in God and the ancestors' souls that control human life. The souls of their ancestors are called Ratu Tempekan Batur. This is the personification of the unified god and the purified souls of their ancestors, including those of the village founders. Altogether, there are 18 deities. They are:

Table 1: List of Gods and Places of Origin

\begin{tabular}{|c|c|c|}
\hline & List of Gods & Place of Origin \\
\hline 1) & Ratu Gede Penataran & \multirow{4}{*}{$\begin{array}{l}\text { These deities are located in the Pura Desa/Bale Agung, } \\
\text { Pacung (Village Temple). }\end{array}$} \\
\hline 2) & $\begin{array}{l}\text { Ratu Gede Maduwe } \\
\text { Karang }\end{array}$ & \\
\hline 3) & $\begin{array}{l}\text { Ratu Gede Duuring } \\
\text { Akasa }\end{array}$ & \\
\hline 4) & $\begin{array}{l}\text { Ratu Ayu Pangentel } \\
\text { Gumi }\end{array}$ & \\
\hline 5) & $\begin{array}{l}\text { Ratu Gede Bhujangga } \\
\text { Sakti }\end{array}$ & This deity's home is Pura Jati at the Batur Lake. \\
\hline 6) & Ratu Ayu Gunungsari & This deity's home is Pura Penulisan. \\
\hline 7) & $\begin{array}{l}\text { Ratu Ngurah Gunung } \\
\text { Lebah }\end{array}$ & This deity's home is Pura Desa Batur. \\
\hline 8) & $\begin{array}{l}\text { Ratu Sesuhunan } \\
\text { Gunung Sinunggal }\end{array}$ & This deity's home is Pura Pucak Sinunggal. \\
\hline 9) & $\begin{array}{l}\text { Ratu Sesuhunan } \\
\text { Gunung Mas }\end{array}$ & \multirow[t]{2}{*}{$\begin{array}{l}\text { These deities are located in the Pura Desa / Bale Agung, } \\
\text { Pacung. }\end{array}$} \\
\hline 10) & Ratu Bagus Nengah & \\
\hline 11) & $\begin{array}{l}\text { Ratu Gede Gunung } \\
\text { Agung }\end{array}$ & $\begin{array}{l}\text { This deity is located on Bali's holiest mountain, Gunung } \\
\text { Agung. }\end{array}$ \\
\hline 12) & Ratu Puseh Duur & $\begin{array}{l}\text { This deity represents the origin of the village that has a } \\
\text { shrine with a pagoda roof in the Village Temple. }\end{array}$ \\
\hline 13) & Ratu Gede Pemaksan & $\begin{array}{l}\text { This deity represents the village community of Pacung; } \\
\text { there is a special shrine in the Village Temple. }\end{array}$ \\
\hline 14) & Ratu Ngurah Bolot & $\begin{array}{l}\text { This deity's home is the Pura Sang Hyang Marek, a temple } \\
\text { on the sea shore used by both Sembiran and Pacung. }\end{array}$ \\
\hline 15) & $\begin{array}{l}\text { Ratu Ngurah Sisin } \\
\text { Segara }\end{array}$ & This deity has also its home in the Pura Sang Marek. \\
\hline 16) & Ratu Gede Dasar & This deity has its home in the Pura Dalem (Death Temple). \\
\hline 17) & Ratu Gede Dikumpi & $\begin{array}{l}\text { This deity, representing the forefathers mainly of aboriginal } \\
\text { Balinese no longer has a definite home; the shrine it once } \\
\text { had in the Village Temple has been abandoned. }\end{array}$ \\
\hline 18) & Ratu Bagus & $\begin{array}{l}\text { This deity has its home in Pacung's Pura Ulun Siwi (Tegal } \\
\text { Suci) Temple. }\end{array}$ \\
\hline
\end{tabular}


Each deity subsumed under the name Ratu Tempekan Batur is worshipped through the niches available at the sanggah dawa. The numbers above and the corresponding deities start according to the niches in the shrine, starting on the left hand side, which is the eastern side. Most of the deities (except Ratu Gede Dasar) subsumed under the name Ratu Tempekan Batur have also a seat in the Pura Puseh/Bale Agung Temple in Pacung and worshipped there by the village community: the deities numbered 1 to 3 share (ngerob) a closed shrine (palinggih gedong); this shrine is located in the most eastern mountainward corner of the Village Temple. The deities numbered 4 to 6 share a shrine in the Village Temple, as do those numbered 7 to 9; 10 and 11 are housed together in yet another shrine again. All other deities have an individual shrine.

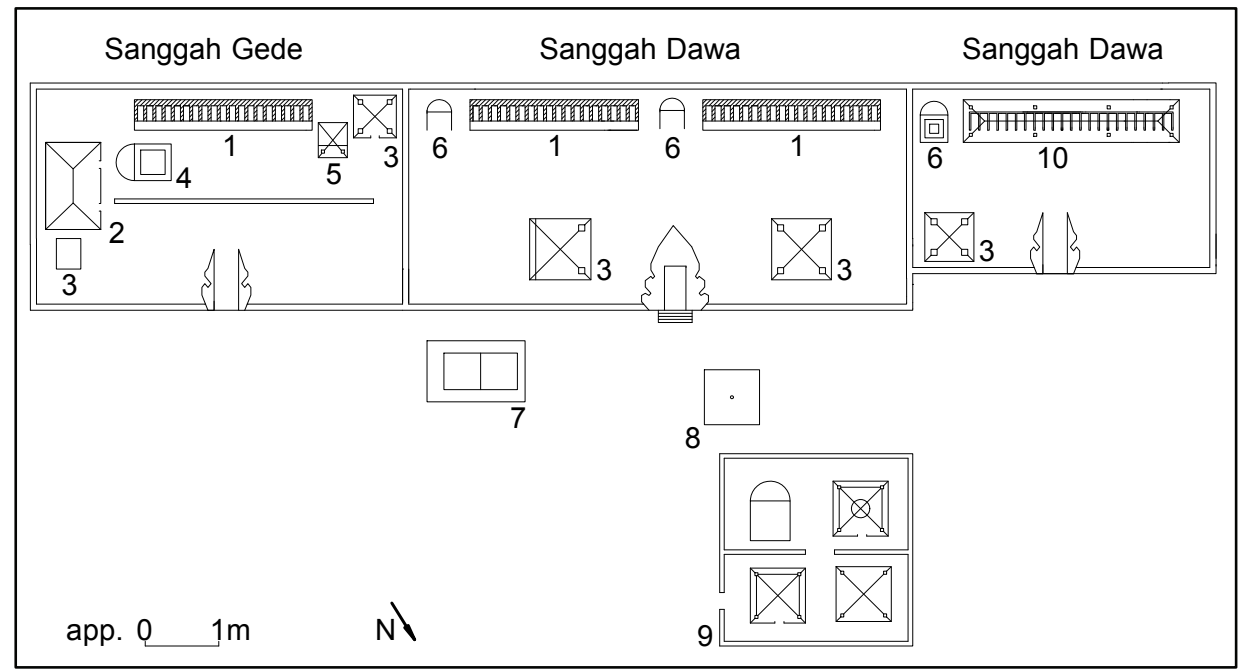

Figure 1: Four sanggah dawa of different lineages of one clan. The one at the furthest right is made of wood, the others of red brick and concrete. No. 1: Sanggah dawa; No.2: Shrine for Sang Hyang Tiga Sakti; No. 3: Piasan; No. 4: Shrine for I Ratu Gede Bujangga Sakti; No. 5: Shrine for I Ratu Susunan Gunung Mas; No. 6: Kemulan, No. 7: Istana Kembar; No. 8: Penunggun Karang; No. 9: Paibon.

The names of the gods and goddesses classified as Ratu Tempekan Batur in the sanggah dawa show that each household temple is closely interwoven with the deities and main temples of Pacung village. The sanggah dawa is more or less a representation of all the major village gods at the individual household. Some of the deities are closely associated with Pacung as a localized community, such as Ratu Gede Penataran, Ratu Gede Maduwe Karang, Ratu Gede Duuring Akasa, Ratu Bagus Nengah, Ratu Puseh Duur, Ratu Gede Pemaksan, Ratu Gede Dasar and Ratu Gede Dikumpi. Others show far-reaching relationships, those to the temples 
at Penulisan and Batur in the central mountain range. A further group of deities are related to sacred places in the neighbourhood, such as the mountain sanctuary of Sinunggal near the village of Tajun or the sea temple of Sang Hyang Marek. The sanggah dawa is an important sacred site in the household temple; usually there is an additional shrine beside the sanggah dawa which is dedicated to Ratu Gede Kemulan, the god controlling the origin of life.

Apart from the sanggah dawa, Nyoman Tisna's clan in Pacung also has a sanggah gede and a paibon where the Unified God (Sang Hyang Tiga Sakti) and the purified forbearers of the clan are worshipped.

A closer examination of sanggah dawa revealed that some have more niches than 18. The one owned by Nyoman Tisna has 22 niches; two sanggab dawa of his closest relatives have nine and one 18 niches. Why do some have more recesses than others? Based on the information obtained from Made Wiryana, the significance of sanggab dawa cannot be separated from the life-cycle ceremonies conducted by a family head.

The members of the krama desa (village association of the Hindu-Balinese) are all married. As family head, a man has to carry out life-cycle rituals as part of the life-long process of purifying himself. There are nine stages in the religious ceremonies that he has to conduct in order to be able to add a further niche to the sanggah dawa. The first stage takes place when he is newly married; this ritual is called mragat. The philosophical meaning of this ceremony is a request for purification and safety for him and his wife in carrying out grahsta asrama (married life).

A few days later, the ceremony mragat is followed by melis, namely a purification ceremony which is performed in the yard, at the house (bale), and in front of the shrine where Ratu Ayu is worshipped by means of holy water (tirta). Then another ceremony follows called maklaci, which is carried out at the Village Temple on the day of the new moon (tilem). This ceremony implies that the man and his wife are socially and legally acknowledged as a new household. The couple now becomes a member (krama) of the desa pakraman; the husband joins the male and his wife the female organization. Maklaci is the formal admission to the sociopolitical and religious village association. To be member of the desa pakraman means to have rights and duties towards the village and its community. On another level, the couple will be also responsible for obligations towards the village temples of Pacung.

The Bendesa Pacung (the leader of ceremonies), I Wayan Liarsa, stated that today the ceremony of maklaci can be carried out any time after the ceremony of melis is finished. There is no longer a special day for maklaci. This arrangement was made because many villagers work away from the village. They have limited time and are, therefore, given time off so that the ceremony can be carried out.

The next ceremony is mapanyari, meaning the offering of devotion at a village temple or at the household temple. In this ceremony an offering of pork is made, called bhakti daar. The next stage of the ceremony is macicipan with an offering in 
the form of a complete pejati which should be presented at two holy places, one at the wife's father temple and the other at Bali Mula family shrines.

If the new family has developed and economically strengthened, the next ceremony to be conducted is bhakti ngaturin bulu geles. This ceremony is directed to Ratu Dalem Tajun (the village is located on the hills) through a place called Pengaturan, which is located on Sembiran territory up the hills and is about two kilometres from Pacung. The ceremony involves six male calves (godel) (two for Dalem Tajun, two for Dalem Bayad and two for Ratu Bolot) with banten pengikutan (a kind of offering) in the shape of one roasted suckling pig (babi guling). The six calves are brought to Pengaturan where they are butchered following a ceremony. Half the meat is used for ceremonial purposes and the other half is consumed together at the location.

The next ceremony is panyicipan consisting of an offering called salaran, a mixture of all kinds of agricultural products such as fruits, tubers, chicken and ducks; this is offered to the gods at Julah's village temple. The next ceremony is called the second bhakti ngaturan and is performed at the Dalem Temple and Dalem Bayad Temple at Tajun. The offerings used at this ceremony are the same as those when bhakti ngaturan bulu geles is conducted, but the roasted suckling pig has to be male. The next ceremony consists of offering bhakti aturan, whose form is identical with that of the second bhakti ngaturan. This is the whole cycle of rituals performed after marriage. It shows on the one hand the extent to which Pacung is interconnected with the neighbouring villages of Tajun, Julah and Sembiran, the latter two being villages from which Pacung is said to be an offshoot. From a comparative perspective, the ceremonial stages mentioned above and their names display many similarities with those in Sembiran (see Riemenschneider and Hauser-Schäublin 2006:39-41).

The meaning of the additional niches on the sanggah dawa can be identified by making a comparison with Hinduism as a philosophy in particular its teachings related to the stages of life and the objectives of human life. In Hinduism, the stages of human life can be classified into four. They are: catur asrama consisting of the learning era (brahmacari), the married era (grhastha), the religion learning era, and, lastly the freeing of the individual from earthly things (vanaprastha) in order to achieve moksa (the heaven - the eternal life). There are also four objectives of life. They are: cultivating religious truth, seeking after wealth (artha), seeking after pleasure (kama), and seeking after eternal life (moksa). The goal of the learning era (brahmacari) is the truth (dharma), the goal of married life (grhasta) is artha (wealth) and the goal of artha, kama and vanaprasta and saniasin is moksa (eternal life).

The family head who has been able to conduct the ceremony of bhakti aturan bulu geles is said to have reached the stage of vanaprastha. The reason is that he has been able to release himself from being attached to earthly pleasures in the forms of artha and kama. Moreover, the family head who has been able to conduct the second bhakti aturan up to the last ceremony after going through bhakti panyipan is 
said to have reached the life stage of saniasin asrama. In Hinduism, if someone has been able to carry out the stages of life and to realize them in his or her daily life well and truthfully, he is stated to be able to achieve his final life goal, that is, eternal life, which can be achieved when still alive and is called mukti. If this assumption is true, he will be given high social status, since he has been able to carry out all forms of devotion (bhakti) and has shown capability in all aspects of life.

\section{Sites of Purified Ancestors' Souls}

The fulfilment of these ritual obligations is a precondition for the performance of a further large ceremony called ngeneman sanggah. This ritual aims at freeing a whole generation (or two) of ancestors (both male and female) from the last ties to earthly life. This large ritual enables the head of the family to add a further niche (rong) to the sanggah dawa. The souls of the ancestors thus freed will then take seat in this additional recess; they are worshipped there by their descendants. Nyoman Tisna's grandfather was the last member of the family who was able to perform this large-scale ceremony. The 22 recesses of Nyoman Tisna's sanggah dawa give evidence of the fact that so far four of his ancestors have carried out ngeneman sanggah since his shrine has 22 niches instead of the 18. Ngeneman sanggah takes place at the family temple; the offerings consist of six pigs. This final ceremony is also a big feast to which all village organizations are invited: all the members of the desa pakraman, sekaa gong (the gong orchestra), sekaa baris (a group of warrior dancers), sekaa rejang (a group of female dancers performing rejang [dance]) and sekaa legong (a group of female dancers performing legong). Among the six pigs, three serve as offerings in the ceremony; two are prepared as a meal for the invited village members and sekaa, and one is used for banten pabangkitan (a kind of offering).

If all the steps of the ceremonies have been gone through without curtailment, the family head is held to have fulfilled his swadharma (holy obligations) as a Hindu follower and is allowed to add one more niche to his sanggah dawa. If a man dies before he can fulfil all the ceremonies, his son has to continue them on behalf of his father. The son cannot complete the life cycle rituals for himself before those of his father have come to an end. It is the son's duty to complete the ritual cycle of his father first. If the son disregards this duty, he is assumed to have broken the norms and to be sinful (alpaca guru rupaka). Unless a man has fulfilled all these duties he is unable to perform ngeneman sanggah.

From what has been described above, it can be concluded that further niches on the sanggah dawa can be added only if all the holy obligations of the preceding and the present generation (swadharma) have been completely fulfilled. In addition, it also means that the family head has succeeded in raising enough money for these expensive ceremonies. Not everybody can put on big and complicated 
ceremonies, only those that are socially, economically and politically capable of doing so.

The attempt of a family head to add a further niche to his sanggah dawa can be viewed as an ongoing competition between family heads. At the same time ngeneman sanggah is a public ceremony organized by a single household. All the covillagers are invited and served with food; therefore, this ceremony constitutes a kind of on-going exchange in the village, continuously producing new relationships of exchange (reciprocity) by giving, taking and owing among the village members. What is given in the form of offerings to the gods/ancestors is classified as niskala (immaterial) and what is later served for the village members is classified as sekala (material). The process of providing niskala and sekala is seen as one single achievement and contributes to the prestige of the person who performed it.

\section{Conclusion}

Sanggah dawa is a particular type of shrine in a household temple. This building constitutes a special form of Bali's cultural heritage, a testimony of Bali's moral values, its history, aesthetics and its symbols. In north Bali, the sanggah dawa represents a typical feature of Pacung village. sanggab dawa serves as a particular place for the worship of God in all his aspects, the power of nature and the purified souls of the ancestors. Such a shrine is always located in the most pure direction of the household temple, which is mountainward. The name of Ratu Tempekan Batur - a collective name for all deities and purified ancestors - accounts for all the divinities worshipped in this row of 18 and more niches. The shrine comprises at least 18 small niches; those are sites where the major deities of the village are worshipped. Further recesses are sites of the purified ancestors' souls that are worshipped there. A further niche may be added only after the completion of all life cycle rituals; it testifies to the fact that the head of the family has already completed swadharman - rituals whose goal is purification and the expression of gratitude towards God. To add a further recess another expensive ceremony to which all villagers are invited is required. This ceremony, ngeneman sanggah, is part of a prestigious exchange system within the village that conveys at the social level high status to the head of the household who has carried them out. Usually only every second or third generation is capable of performing such a ritual. To all his descendants, the existence of more than 18 niches on the sanggab dawa is an object of pride. At the level of religion, such a completion empowers a person to perform all types of rituals without any further restriction. 


\section{References}

Ardana, I Gusti Gede

1986 Unsur Megalitik dalam Hubungan dengan Kepercayaan di Bali. In: Makalah

Pertemuan Ilmiah Arkeologi, Jakarta, 1980.

Hendropuspito, D.

1983 Sosiologi Agama. Jakarta: Kanisius.

Koentjaraningrat

1980 Sejarah Teori Antropologi, Vol. I. Jakarta: Universitas Indonesia Press.

Riemenschneider, Christian und Brigitta Hauser-Schäublin

2006 „....Yang Hidup di sini, Yang Mati di sana“: Upacara Lingkaran Hidup di Desa

Sembiran, Bali (Indonesia). Göttinger Studien zur Ethnologie, Bd. 15. Münster:

LIT-Verlag.

\section{List of Informants}

I Nyoman Tisna, 56, Banjar Kubuanyar, Pacung, Retired Government Civil Servant; Wood Carver and Architect.

I Wayan Liarsi, 70, Banjar Kubuanyar, Pacung, Bendesa Adat

I Made Wiryana, 53, Banjar Kubuanuyar, Pacung, Head of Banjar Kubuanyar, Pacung 


\section{Environment and Change}





\title{
Changes in the Landscape
}

\author{
Enrico Kalb
}

\section{Introduction}

In view of globally increasing "landscape use" due to new development, roads and forest clearance to create new agricultural areas, natural areas are subject to extreme change. Studies of land use change are thus becoming increasingly important.

The area under investigation is located on the northeast coast of Bali, for whose components a lasting anthropogenic settlement and, subsequently, a reshaping of the landscape by the people is already evident. The origins of the reshaping of the landscape and its vegetation in the last century will be examined in the study through general physiographic work processes with regard to vegetation. In addition to pedogenic and geological considerations, a three-dimensional figure of the globe's surface will also be used.

\section{Physiographic Aspects}

\section{Introduction and Land Form}

Approximately $102 \mathrm{~km}^{2}$ in size, the area under investigation is located on the northeast coast of Bali and belongs to the districts (kabupaten) Buleleng and Bangli. It is situated approximately $30 \mathrm{~km}$ east of the centre of the former harbour town 
of Singaraja and covers parts of the sub-districts (kecamatan) Kubutambahan and Tejakula (Figure 1 in the Introduction to this volume).

The fringe threshold of the north-eastern region of Bali is divided into two parts running from north to south (Figure 1).

The coastal plain runs northwards into the Bali Sea and shows soil rich in nutrients at a low inclination of $1^{\circ}$ to $3^{\circ}$ (occasionally a maximum of $5^{\circ}$ ) with coarse sand. Its low relief is partly responsible for the presence of main roads with numerous towns and villages on the coastal strip. Moreover, the coastal plain offers a good location for horticulture, as the low sea-level in connection with a high ground-water level facilitates irrigation all the year round through self-dug wells.

The transition from coastal plain to mountain area is usually very abrupt and characterised by savannah landscape which runs up to the gardens of the settlements.

The mountain area constitutes a rather steady rise next to the deeply carved mountain range of the Ayung Valley to the east of the area under investigation with an average inclination of 13 degrees and a relief increase of 1.000 metres. This inland rise is determined by the second largest and active volcano (Batur $1.712 \mathrm{~m}$ above sea-level) whose lava fields and ash rain settle in the region. Small plateau fields and deep valley forms with retrogressive erosion mark the morphological shape of the area.

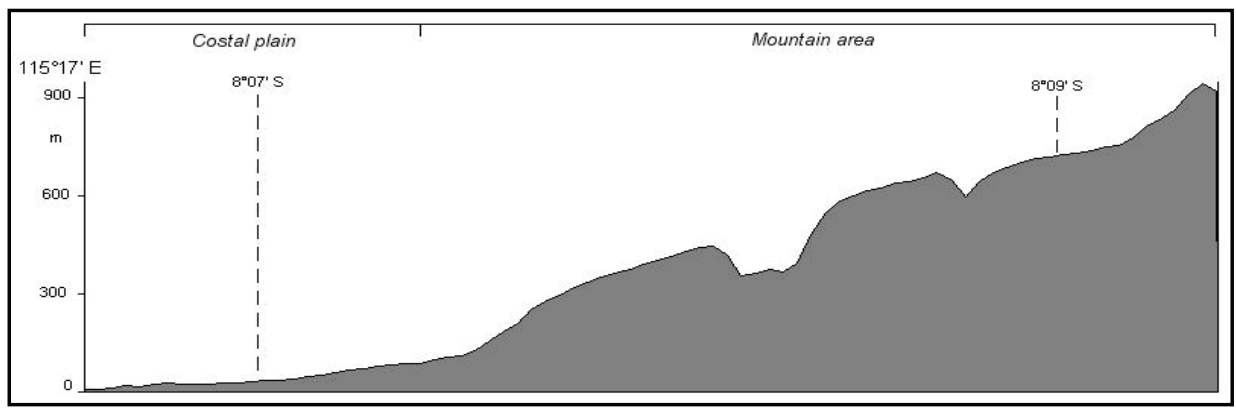

Figure 1: N-S profile of the area under investigation on the geographic longitude of $115^{\circ} 17^{\prime} \mathrm{E}$.

\section{Climate}

The tropical monsoon climate is affected by the monsoon winds, which shows a diurnal climate in which the temperature fluctuations within a year move below those of a day. The air temperature reaches on average approximately $26^{\circ} \mathrm{C}$ in altitudes below $500 \mathrm{~m}$ above sea-level. Changes in temperature take place with increasing altitude, where the air mass cools below the saturated adiabatic lapse rate of $0,6 \mathrm{~K}$ per $100 \mathrm{~m}$ (Whitten et al. 2000). 
With approximately 1.700 to $1.800 \mathrm{~mm}$, the annual amount of precipitation for the north-eastern area of Bali is low compared to most other regions of Indonesia, which have 2.000 to $3.000 \mathrm{~mm}$ (Domrös 1979). Figure 2 illustrates the crucial role of macrorelief in the distribution of precipitation in and around the area under investigation. The unequal distribution of the values depends upon the orographic rise of air mass and the associated precipitation of the surplus water in the cooled air and through air mass convergence, convection of high equatorial radiant intensity and local wind convergence in the mountain range.

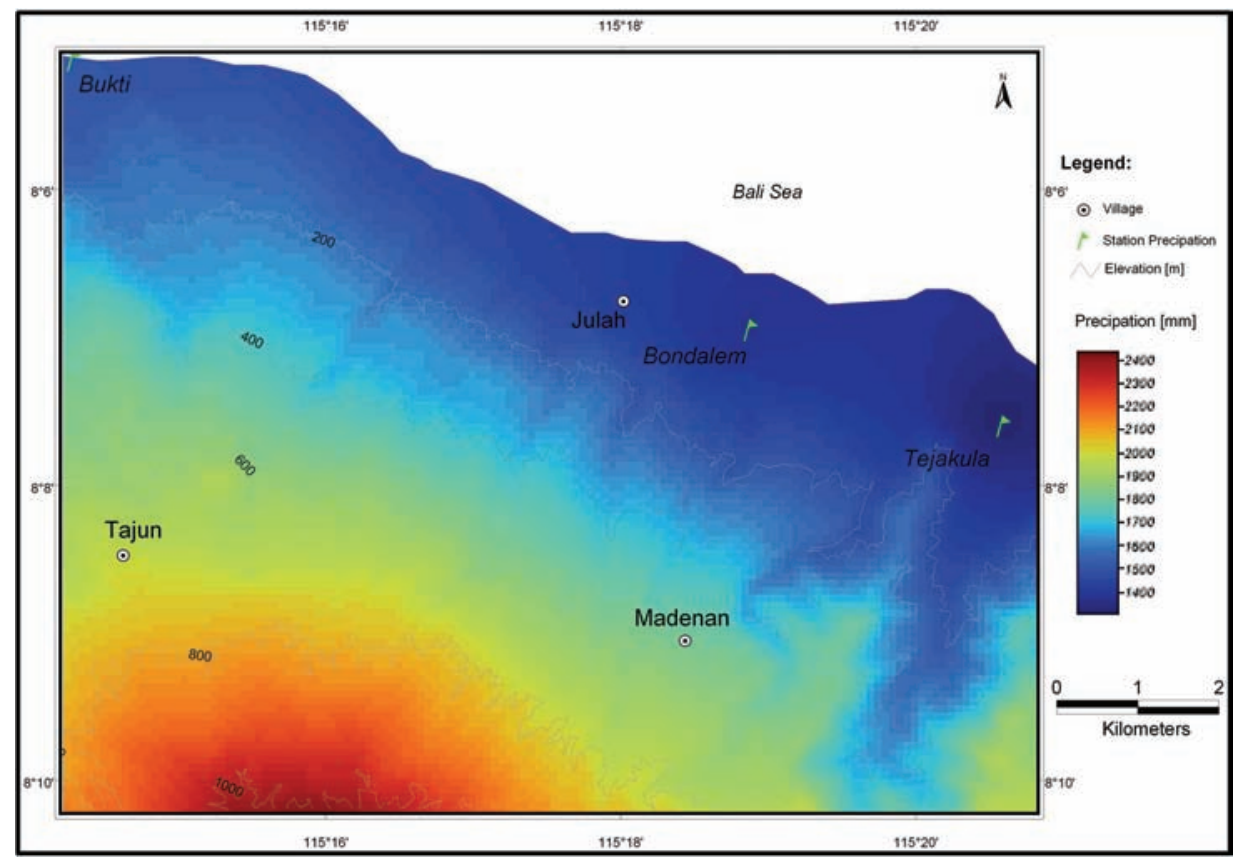

Figure 2: The map depicts the average and classified annual figures for precipitation from 1983 to 2000. The values were calculated in association with the regressive rise of the ground level using the spatial-stochastic interpolation process "kriging".

\section{Soil}

The in-situ volcanic rocks in the area under investigation form a good basis for the emergence of nutritious soil and, thus, the cultivation of agricultural areas. Falling of recurrent ash rain (Uhlig 1979) from the nearby volcanoes Batur and Agung has also contributed recently to the mineralization of the soil. The prevailing soil type is confined to regosol according to the FAO classification (Food and Agriculture Organization of the United Nations) (Schmidt 1979), and consists therefore of soil that contains more than $20 \%$ of volcanic loose masses as source 
material or higher proportions of allophanes (sorption-heavy clay minerals). The porousness and good permeability of the soil, as well as its large nutrient reserves, ensure high fertility.

The river valleys and flat coastal sections are distinguished by alluvial and lahar soil (mud stream of water and ash arising in volcanic eruptions). The superficial close lahar soil in the north-eastern coastal region comes primarily from an alluvial complex composed of volcanic materials (andesite, volcanic breccia, tuff and ash) (Eelaart 2003). Drilling carried out by the Institute "Sustainable Development of Irrigated Agriculture in Buleleng and Karangasem" showed that the alluvial fans in the coastal area on average reach sizes between 1 and 25 metres. The soil types of the fluviatile sediments fluctuate between sandy loam and clay stone with a coarse texture. Inland, the fans gradually decrease in proportion to inclination of the relief and the relative altitude to the sea. In addition to the frequently occurring regosols, fluvisol soil and, on the coast, occasionally cambisol soil were also categorised in the area under investigation (Eelaart 2003).

\section{Geology}

The active volcano Batur, which borders the area under investigation and has been in existence for approximately 500.000 years (Sutawidjaja 1990), contributes considerably to the prevailing subterranean conditions of the area up to this day. As we can gather from the geological map (Figure3), the largest area is occupied by volcanic rock. The andesitic-basaltic igneous rocks of the volcanoes Buyan and Bratan, situated to the southwest, and the south-eastern Batur volcano are classified as belonging to the Holocene Period in the geological time scale (100.000 to 60.000 years ago).

The combination of several forms of chemical and physical weathering in the subtropical and tropical latitudes has led to the genesis of a loose mass blanket in the area just below the surface. These weathering products and, at the same time, sediments are subject to fluvial erosion and fluvial accumulation in the rain season. The accumulation takes place primarily in the coastal area or directly in the sea.

The weathering products of this constantly visible process are referred to as $\mathrm{Q} a$ and are among the youngest geological phenomena in the area under investigation. The volcanic rocks with the name Qvbb can be attributed to an eruption of the Buyan-Bratan volcanoes during the mid-Pleistocene period (approx. 500.000 to 1,3 mn. years ago). They are made of volcanic breccia and extrusive rocks with enclosed tuff. They belong to the Asah formation, which characterises the coastal area from Bondalem to Bukti. The formation arose in the Pliocene Period (approx. 1,6 to $5 \mathrm{mn}$. years ago). 


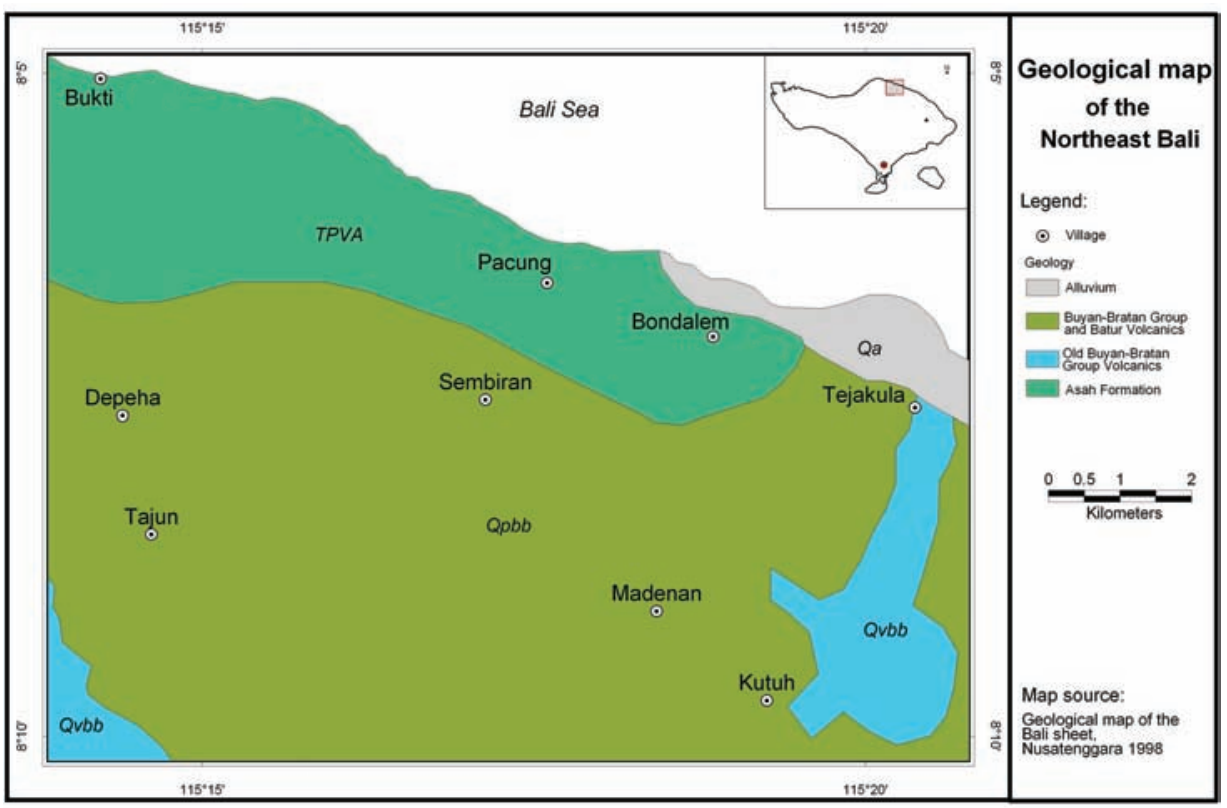

Figure 3: Geological map of the area under investigation (altered according to GRDC 1998).

\section{Investigative Methods and Data Basis}

The extensive registration of the landscape change in the area under investigation is carried out using two periods (1923 and 2004), for which precise map resources were made available. For the first period, maps were used dating from the years 1923 to 1925 during the Dutch colonial era. As the Dutch at that time were mainly interested in profitable export goods such as rubber, coffee, tea and sugar, comprehensive land use was recorded on the maps. Furthermore, detailed information regarding the size of settlements, individual locations and altitude are illustrated in the specimens available as colour prints drawn to a scale of 1:50.000.

The topographical maps from the institute BAKOPSURTANAL (Badan Koordinasi Survey dan Pemetaan Nasional) from Jakarta, drawn to a scale of 1:25.000, formed the data basis for the second period. The maps were reprinted in 1999. Aerial photographs from 1993/94, which were processed photogrammetrically to a scale of 1:50.000 and combined with field photographs from 1999 served as a basis. In order to make the present comparison of the two periods 1923 and 2004, high-resolution pictures were ordered from the QuickBird sensor of DigitalGlobal $^{\odot}$ on 1. September 2003. The sensor provides the data in two different types of picture. The first is with a 2,44 to $2,88 \mathrm{~m}$ resolution in a three-channel 
multispectral mode and close-up, infrared. The second photograph is carried out in black and white mode (panchromatic mode) with a resolution of 0,61 to $0,72 \mathrm{~m}$.

The data available for each period was converted into digital form using the software PCI Geomatica ${ }^{\odot}$ and geo referenced.

Mapping of the types of land use was carried out for each period using the geographic information system ArcGIS 9.0 . The pre-processed multispectral satellite picture was classified beforehand by means of an unattended classification using the software ENVI $4.0^{\circ}$. The land use map produced was tested and improved on site through a sampling procedure in minimum areas of a 0,1 ha surface, and vegetation units could be assigned to the spectral values. This led to a formulation of the vegetation complex, characterised floristically through dominant species. Afterwards, the area percentages were calculated. Moreover, in order to obtain a more differentiated analysis of the area, a construction of the Digital Terrain Model (DTM) was carried out, which related to the geomorphological units, such as inclination, elevation and exposure.

Written sources - primarily statistic year books of the CKS (Central Kantoor voor de Statistiek van het Department van Economische Zaken) - verbal records and earlier photographs facilitated chronological classification and clarification of the causes of the changes established.

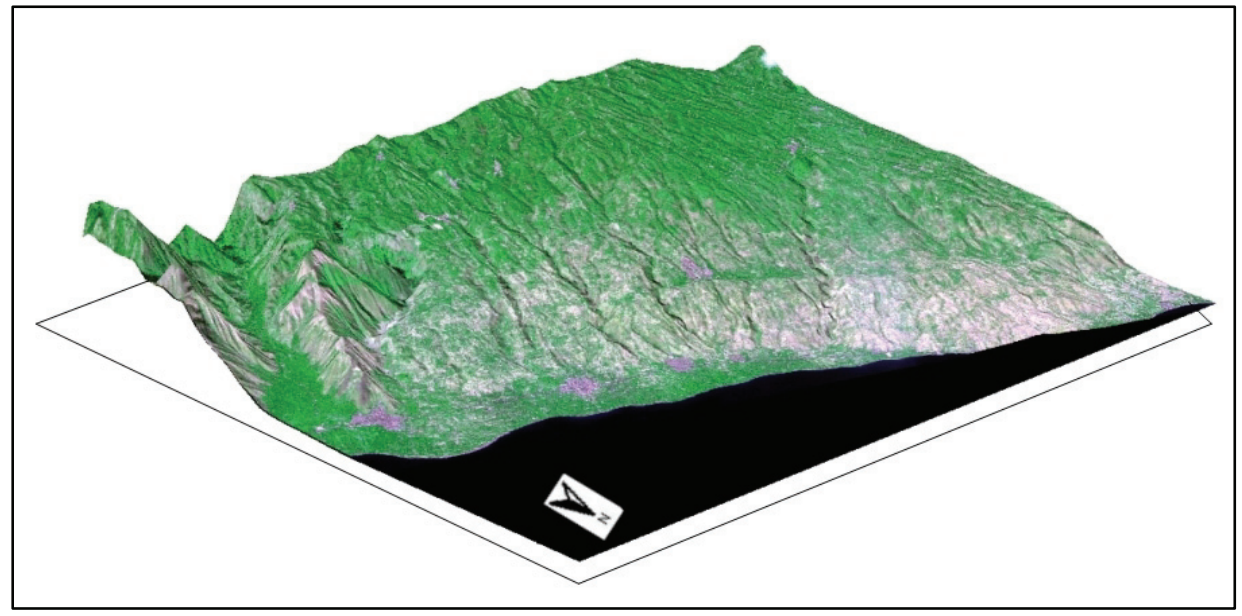

Figure 4: Three-dimensional representation of the area under investigation with triple transversal slopes. 


\section{Results}

\section{Land Use Analyses by Means of a Satellite Picture and Mapping}

The botanic examination concentrated on an analysis of the occurring vegetation ratios in the area under investigation. At the same time, the structures of the habitats were analysed for their floristic compositions and frequency, and in this way the significance of individual plant types in each habitat was established.

Two gradients were recognised as landscape-defining for the area under investigation, based on the interpretation of the satellite picture: a north-south gradient, reflecting the influence of the high altitude climate, and an east-west gradient, caused by the anthropogenic intervention of the irrigation canal built in the area of the Ayung Valley (south Tejakula). The coastal road, which follows the direction of the east-west gradient, was chosen as a starting position for the areas of investigation situated further away. The locations of these areas depended upon the previously classified vegetation complexes and the degree of availability (Kalb 2006).

On the basis of classification made with the help of the processed satellite picture and later verification during field work, nine land use categories could be distinguished. Seven of the nine land use categories were considered to be vegetation categories; the categories Settlement and Vegetation-free have to be considered separately. In the case of Settlements, areas are meant that are sealed off by development (houses, streets etc.). Vegetation-free areas are characterised by their relief conditions. In the higher and steeply sloping regions, the soil erosion is so high that no soil development can build up sufficiently to support a vegetation layer.

Figure 5 illustrates the result of the land use mapping made possible by the QuickBird scene and the field photographs. The elevation classes marked in colour on the map reflect the cultivation of high altitude-climatic plant communities. 


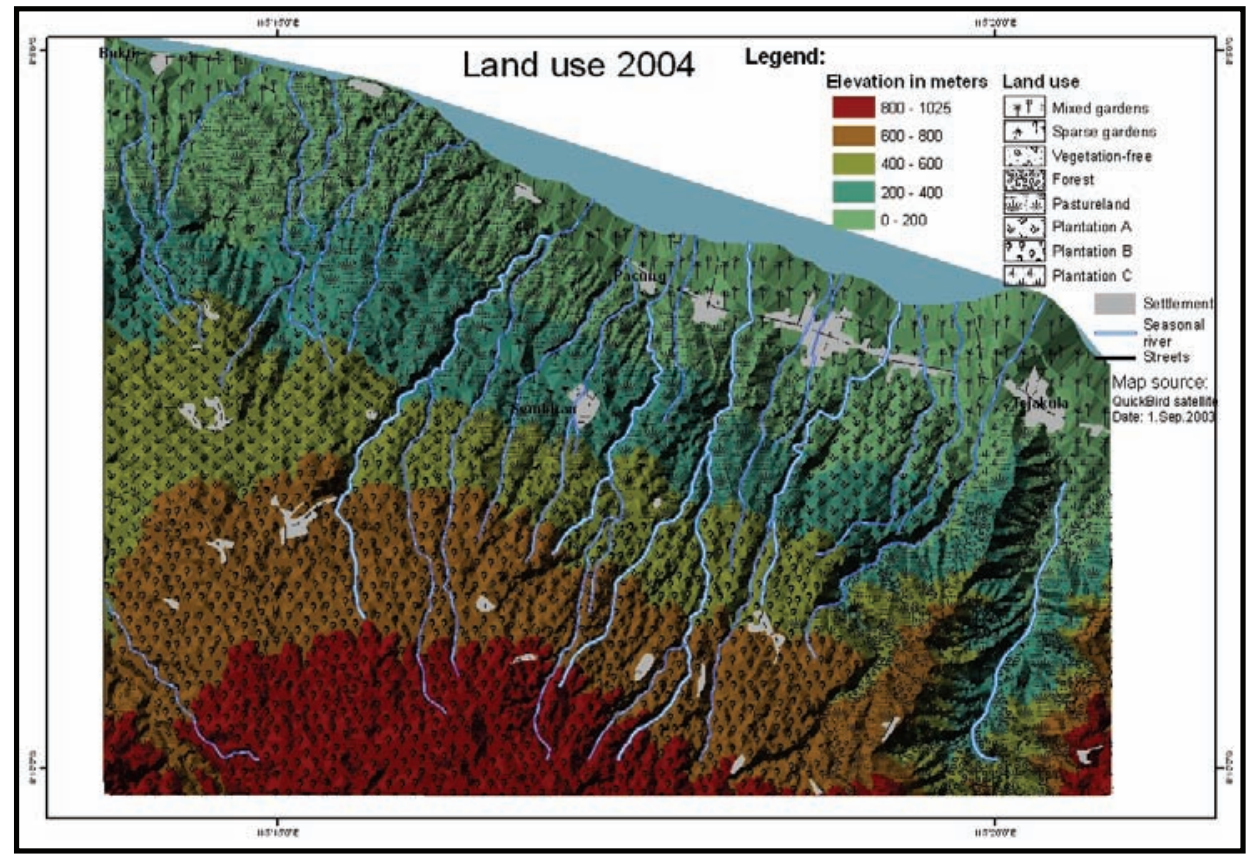

Figure 5: The land use of the region under investigation in 2004 with information on elevation.

\section{Land Use Analysis from Historical Maps}

For the historical land use classification, topographical maps were implemented ${ }^{1}$, the age and origin of which are mentioned in above. After the preparation of the charts, they were compared with the satellite picture with integrated criteria. In the interpretation of the historical charts, very precise cartography could be identified. Differences arise primarily in the names of settlements or rivers that differ from the current ones.

The symbols included in the historical charts illustrate the prevailing vegetation of the time extensively. Scale settlements with detailed information also appear in them.

For the classification of land use, the dense, point-like symbols have to be projected in areas from the analogue chart. The borders of the vegetation units were interpolated visually with GIS using these symbols. Six units of land use were recorded here categorized as Mixed gardens, Plantation coffee, Sparse gardens,

\footnotetext{
${ }^{1}$ For the evaluation of historical land use analyses, remote sensing records provide a better basis than historical charts. Research based on aerial photographs or similar techniques remained inconclusive. The historic charts provide the only freely available access to bygone vegetation.
} 
Settlements, Vegetation-free and Savannah. The figure below illustrates the area under investigation with the vegetation as it was in 1923, when the topographic maps were drawn.

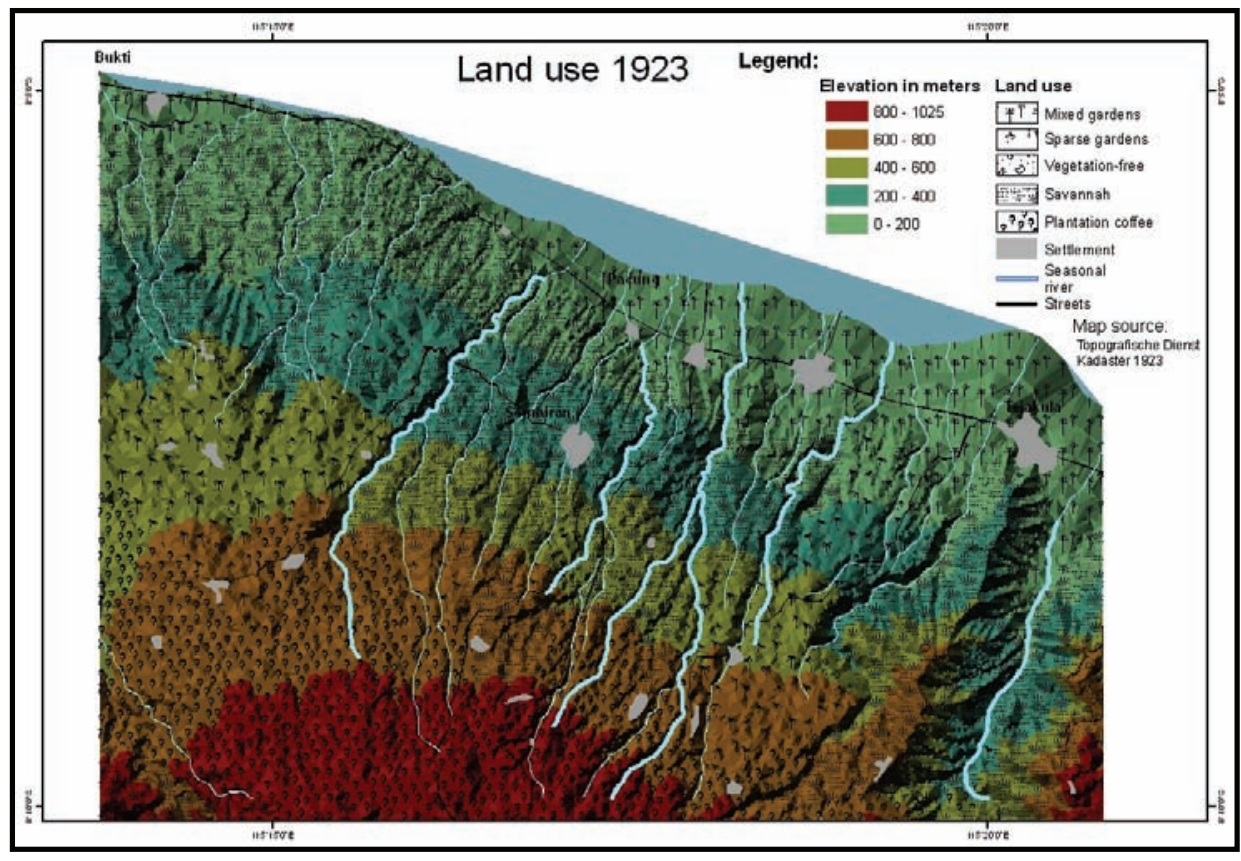

Figure 6: The land use of the region under investigation in 1923 with information on elevation.

\section{Accuracy Evaluation of the Vegetation Analysis}

In any current evaluation of historical data for the purpose of a historical landscape analysis, one can assume that it involves data that are not optimal for the purpose of evaluation. Although the maps made available in this study contain informative evidence of land use, they also conceal many details in the reproduction scale which can be emphasised in the QuickBird scene of 2003 with a soil resolution of $0,6 \mathrm{~m}$.

In the registration of changes in the landscape, there is also a lack of available material for the cartographers with regard to content. Consequently, unclear distinguishable objects are represented by sharp borders. In addition, geometric errors have to be taken into account in the registration of objects on an evaluation board.

The characteristics of land use in the historical maps are based upon symbols which usually only express individual plant genera. These could only be inter- 
preted and classified by adopting an approach according to the principle of relevance regarding today's vegetation. The results of the areas have to be viewed critically due to the interpolation and the actualistic principle; nevertheless, the area percentages of the individual classes in the overall picture and their changes within the period are relevant compared to the general development of the island state of Indonesia.

\section{Change Detection}

According to Myint (2001), change detection is the registration of changes, and therefore a process in which the difference of a single object is identified and investigated through observations at different times.

To enable interpretation of the change in land use by means of the multitemporal QuickBird scene and the maps supplied in the period of 1923 to 2003, both pictures were classified. The following addition was also made. The previously investigated land use categories from both pictures were standardised to facilitate a representative comparison. This resulted in the amalgamation of the categories Plantation A, B, C and Plantation coffee as "Plantation" and Forest and Savannah as "Savannah". All of the other classes retained their original name.

The arithmetical results of the comparison of the area percentages of the individual classes of both periods are illustrated in Table 1 and Diagram 1. The result of both classifications was illustrated in Figure 7 through the intersection of all categories with GIS.

Table 1: Percentage Comparison of the Land Use Shares between 1923 and 2003

\begin{tabular}{|l|l|l|l|}
\hline Class & $\begin{array}{l}\text { Share in \% } \\
1923\end{array}$ & $\begin{array}{l}\text { Share in \% } \\
2003\end{array}$ & Balance in \% \\
\hline Mixed gardens & 13.77 & 10.65 & -3.12 \\
\hline Rivers & 3.10 & 2.82 & -0.28 \\
\hline Roads & 0.24 & 0.72 & 0.48 \\
\hline Plantations & 23.70 & 47.38 & 23.68 \\
\hline Settlements & 1.26 & 2.07 & 0.81 \\
\hline Sparse gardens & 16.43 & 3.08 & -13.35 \\
\hline Vegetation-free & 1.42 & 1.18 & -0.24 \\
\hline Savannah & 40.08 & 32.11 & -7.97 \\
\hline
\end{tabular}




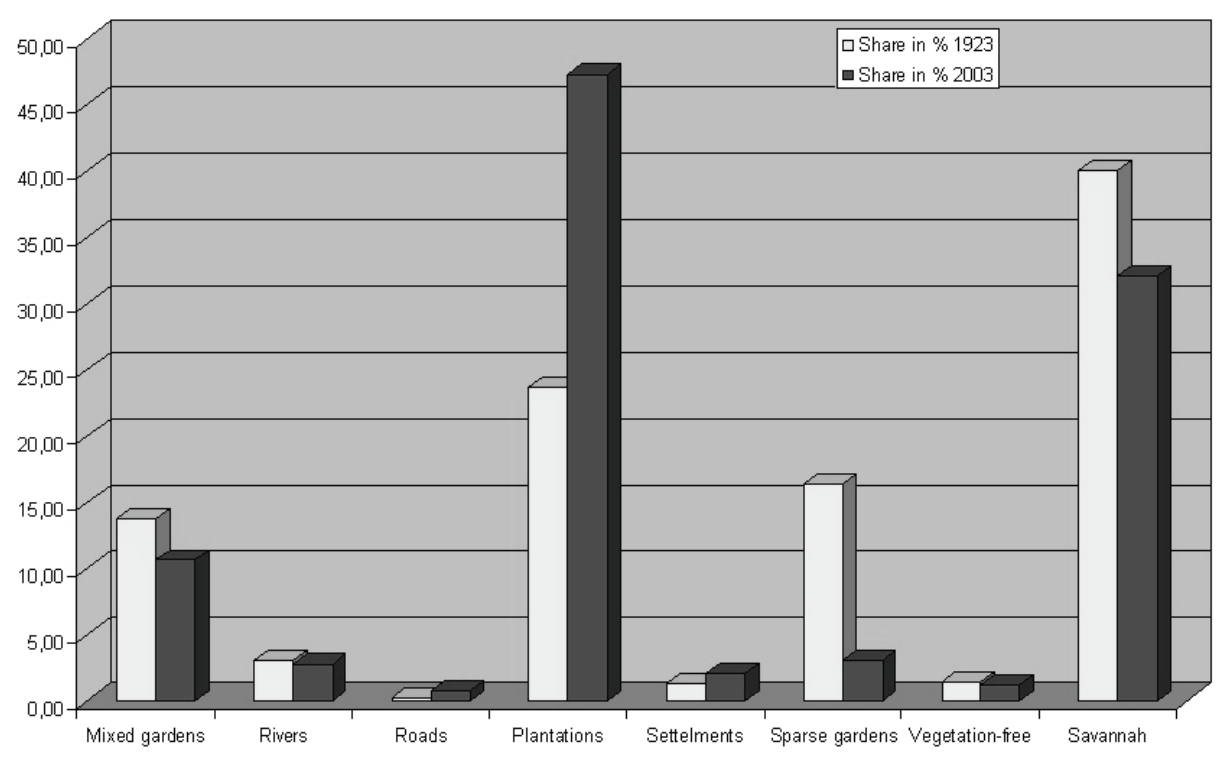

Diagram 1: Percentage comparison of land use proportions between 1923 and 2003.

\section{Interpretation and Discussion}

The results of the land use categories should be viewed critically as the surface shares do not serve as absolute numbers but rather as approximate values. The observations of the accuracy evaluation (see above) indicate that a precise classification is difficult. For this reason, classes where land use change is on balance below $1 \%$ are not examined more closely. However, in this study, significant errors in the land use classification cannot be assumed.

The category Plantation displays the clearest change within 80 years. It constitutes the second largest land use category in 1923 with 23,68\% and is the largest land use category in 2003 with an area percentage of 47,38\%. The growing demand for export agriculture, such as coffee, cocoa and cloves saw an increase in cultivation of $100 \%$ in small farming businesses within the period measured. According to the CKS (Central Kantoor voor de Statistiek van het Department van Economische Zaken) of 1938, the demand for products from the plantation business is extremely low compared to that of today. Not even a third of the few areas reserved for plantations were actually cultivated. 
The extent to which the cash crops of 1923 (within the plantations) differed from the present agricultural dominance could not be analysed in detail. However, it can be assumed that it was a homogenous coffee plantation in comparison to the mixed plantation of today as the coffee symbol is used exclusively in the historic maps.

It was clear from the current mapping that the areas of the plantations under cultivation are increasing. A significant extension of these areas has occurred in the east along the Madenan-Bondalem road. Furthermore, the cultivation of the cash crops to the west of the area under investigation has been extended around the village of Tunjung. The extension of both of these regions has occurred on former Sparse gardens. This also includes the plantations south of Tejakula, which were only laid out in the 1990s. The extension was mapped on a small scale in the centre of the area under investigation where cultivation took place on former savannah country.

The second largest land use change, with a deficit of $13,35 \%$, was analysed in the category Sparse gardens. It has been increasingly replaced by the cultivation of plantation agriculture in recent decades. The settlement of ethnic groups in the region can be named as a reason for the advance of cash crops in unfavourable locations, for which the expanding population and immigration on Bali has been responsible in recent decades. The statistics from 1930 substantiate this: 1.101 .393 inhabitants (CKS 1938), 1971: 2,120,322 inhabitants and 2000: 3.151 .162 inhabitants (http://www.bps.go.id 2005).

In the same way, the Savannah has shrunk also from $40,08 \%$ to $32,11 \%$. The following development can be seen in most areas: plantations have emerged today where Sparse gardens and Savannah could be found adjacent to each other in the 1920s. This kind of plantation can be classified without exception under the plantation A category presented here.

In the case of Mixed gardens, there is a negative balance of $3,12 \%$. This is the result of the loss of the gardens in the areas south of Bondalem to Pacung and the expansion of the gardens in the north-western area of the area under investigation. The land use change of Mixed gardens occurred on savannah landscapes, or was taken over by these. 


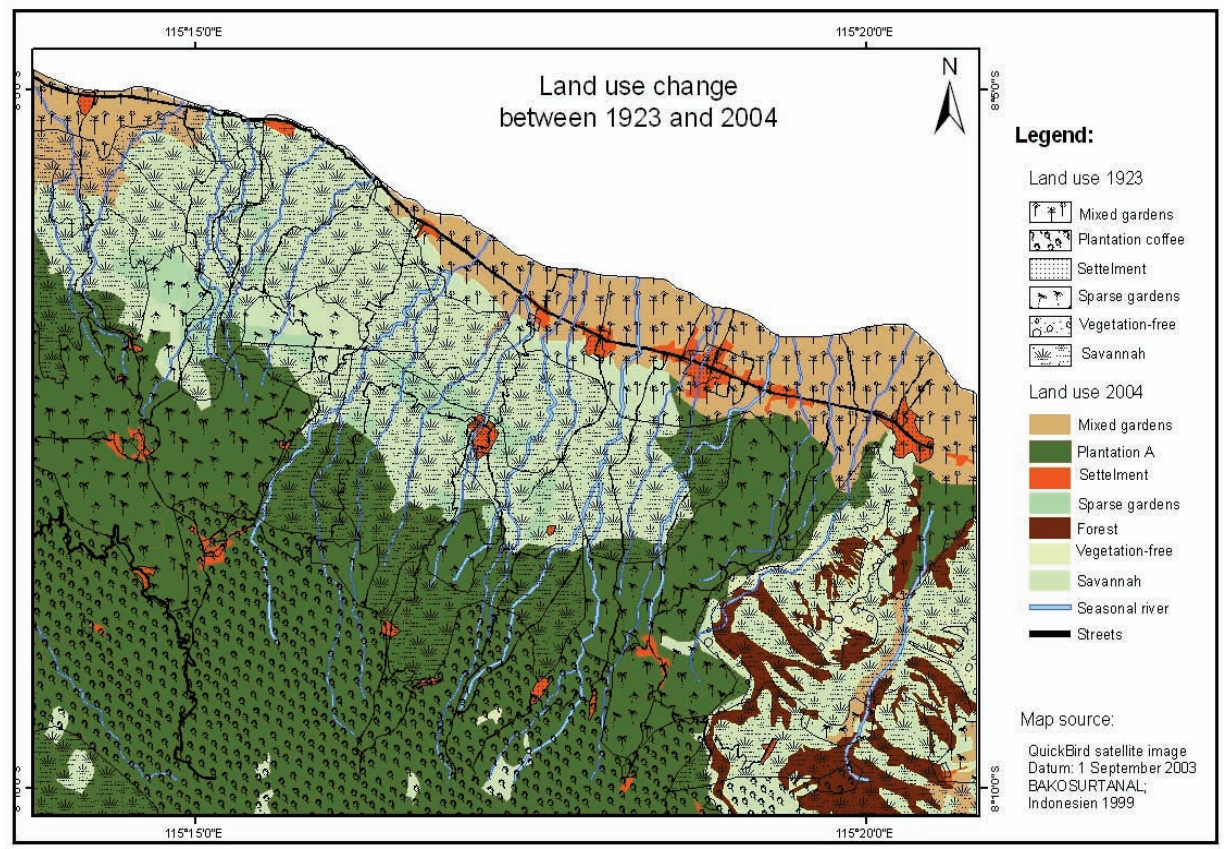

Figure 7: The land use change of the area under investigation between 1923 and 2004

\section{Summary}

In the existing study, a description of land use change between 1923 and the present was carried out for the area under investigation. To achieve this, a map including historical data from 1923 during the Dutch colonial period, botanical ground surveys from the summer of 2004 and high resolution satellite pictures from the sensor QuickBird ${ }^{\odot}$ on $1^{\text {st }}$ September 2003 were put together. For classification of the present land use, the QuickBird ${ }^{\odot}$ scene from the $1^{\text {st }}$ September was available. During the site visit in the summer of 2004, more detailed and informative data was recorded for the land use classification to be made. The historical data referred to for the differential analysis originate from the Dutch colonial period and provide good insights into the land use ratios around 1923 in the form of topographical maps. The available data records were subject to pre-processing and adapted to an integrated digital reference system. The investigated land use areas as seen on historical topographical maps could not be further checked and thus had to go into the classification from 1923. The results of both classifications were compared to using geographic information system, and changes in land use between the two periods were calculated. The land use classification produced 
eight categories which differed in their percentage area balance between 1923 and 2003 as follows: Mixed gardens $(-3,12 \%)$, Plantation $(+23,68 \%)$, Sparse gardens $(-13,35 \%)$,Vegetation-free $(-0,24 \%)$ and Savannah with Forest $(-7,97 \%)$. The categories Settlements, Roads and Rivers occupy the least significant area percentages in the area under investigation together with the category Vegetation-free. The result of the change detection shows the greatest changes within the plantations. With an area percentage of over $47 \%$, it presently represents the largest land use category in the area under investigation.

\section{References}

Bandan Pusat Statistika

2005 http://www.bps.go.id/index.shtml; (24.07.2005).

Central Kantoor voor de Statistiek van het Department van Economische Zaken

1938 Statistisch Jaaroverzicht van Nederlandsch-Indie over het Jaar 1936. Indisch Verslag, Batavia. In: Zimmermann, G.R. (2003): Indonesien: eine geographische Landeskunde; S. 157. Nackenheim: Ed. Matahari.

Domrös, $\mathrm{M}$.

1979 Klima-Niederschlag. In: Junghans, K.H. et al. (Hg.): Indonesien: Geographie, Geschichte, Kultur, Religion, Staat, Gesellschaft, Bildungswesen, Politik, Wirtschaft. Tübingen; S. 21-31. Basel: Horst Erdmann Verlag.

Eelaart, A. van den

2003 Mission Report of the Tropical Soils and Land Use Specialist. Sustainable Development of Irrigated Agriculture in Buleleng and Karangasem. Project IDN/RELEX/2001/0087; pp. 5-8. Singaraja.

Geological Research and Development Centre (GRDC)

1998 Geological Map of the Bali Sheet. Bandung.

Kalb, E.

2006 Erosionsmodellierung und Landnutzungsinterpretation der Küstenregion von Nordost Bali, Indonesien. Stuttgart: ibidem-Verlag.

Myint, O.

2001 Untersuchungen zur Anwendung von Satellitenfernerkundung und terrestrischen Aufnahmen zum forstlichen Monitoring und zur Planung im tropischen Regenwald, am Beispiel in Bago District in Myanmar. Göttingen: Cuviller.

Schmidt, H.L.

1979 Geologie und Lagerstätten. In: Junghans, K.H. et al. (Hg.): Indonesien: Geographie, Geschichte, Kultur, Religion, Staat, Gesellschaft, Bildungswesen, Politik, Wirtschaft; S. 7-14, 24-29, 44-58. Tübingen, Basel: Horst Erdmann Verlag. 
Sutawidjaja, I.S.

1999 Gunung Batur. Berita berkala Vulkanologi. Edisi Khusus, Direktorat Vulkanologi, No. 158.;

http://www.vsi.esdm.go.id/gunungapiIndonesia/batur/geologi.html; (24.07.2007).

Uhlig, $\mathrm{H}$.

1979 Oberflächeform und Böden. In: Junghans, K.H. et al. (Hg.): Indonesien: Geographie, Geschichte, Kultur, Religion, Staat, Gesellschaft, Bildungswesen, Politik, Wirtschaft; S. 7-14, 24-29, 63-64. Tübingen, Basel: Horst Erdmann Verlag.

Whitten, T., Soeriaatmadja, R. and S. Afiff

2000 The Ecology of Java and Bali. The Ecology of Indonesia Series, Vol. II: 117-128.

Singapore: Periplus. 



\section{Archaeological Evidence and its Interpretation}





\title{
Archaeological Traces of the Early Harbour Town
}

\author{
I Wayan Ardika
}

\section{Introduction}

Systematic archaeological research at Sembiran and adjacent areas in north-eastern Bali was commenced in 1987. Finds at Sembiran and Pacung included Indian and local potteries, glass and carnelian beads, metal objects, human burials, and other organic materials. The appearance of Indian potteries at Sembiran and Pacung as well as the occurrence of inscriptional data suggest that these sites may have functioned as an ancient port at least from the beginning of the first millennium $\mathrm{AD}$ up to the $12^{\text {th }}$ century AD.

The archaeological research at Sembiran and adjacent areas was inspired by the inscriptional data which were written on 20 copperplate inscriptions dated from AD 922 to AD 1181. In 1965, these inscriptions were divided by the villagers of Sembiran and Julah, and each village kept 10 of these each. Several facts in relation to the village and the inhabitants of Julah were mentioned in these inscriptions. For instance, the inscription of Sembiran A I dated to AD 922 mentioned a market (pasar), and a market officer (ser pasar) at Julah. Apart from that, a regulation concerning stranded ships and their cargos (tawan karang) also appeared in the inscription. It is also mentioned that people who lived in a fortified settlement (kuta) at Julah were attacked by their enemies, forcing some of them to flee to other villages. 
It should be noted that the terms kuta and ser pasar (market officer) are also mentioned in the inscription of Bebetin A I dated to AD 896 (Goris 1954:54). A kuta within the territory of Banwa Bharu is noted in this inscription. Banwa Bharu could have been another port site in north Bali, possibly located near the modern village of Sangsit, about $15 \mathrm{~km}$ west of Julah, where a small port still exists.

The provisions of the banigrama (merchant guild) that resided in kuta are also mentioned in the inscription of Sembiran A II dated AD 975. The term banigrama also occurs in contemporary East Javanese inscriptions, particularly in port areas. From the $10^{\text {th }}$ century Javanese inscriptions, the term banigrama is associated with foreign traders including Chams, Khmers, Mons, Singhalese, Bengalis, Kalingas, Podikiras, Karnataka, Dravidis and Aryyas (Barret Jones 1984:23; Wisseman 1977:207).

The inscription of Sembiran A III dated AD 1016 mentioned the villagers of Julah who had been scattered and fled to other villages. Some of them were killed by enemies. In all, there remained in the village only 50 families out of an original 300. The village therefore asked the Balinese Queen (Sang Ratu Sri Ajnadewi) for a reduction in their taxes and other responsibilities.

An interesting fact concerning seafaring merchants (banyaga) who anchored at Manasa with their ships and boats was also mentioned in the inscription of Sembiran A IV dating from AD 1016 (Ardika 1991:144). Manasa could be another port site in north Bali that is still unknown. Regulations concerning maritime vessels anchored at Julah were also mentioned in the inscription of Sembiran $\mathrm{C}$ dating from AD 1181. The samgat badwa haji and the kabayan gosti had authority to inspect the cargos of these ships (Ardika 1991:148). Based on the contents of these inscriptions, Julah and nearby areas seem to have been involved in maritime trade between the early $10^{\text {th }}$ to $12^{\text {th }}$ centuries AD. During the early 10 th century AD, the trade activities at Julah were probably carried out from a kuta or fortified settlement. The settlement itself was plundered many times, perhaps by pirates, and its inhabitants were sometime killed, captured, or they fled to other villages. Foreign traders or banyaga came to Julah and lived there in a guild (banigrama).

Archaeological excavations at Sembiran and Pacung, which are located less than one kilometre west of the modern village of Julah, have now produced a good deal of data that proves these sites could be an ancient harbour dating at least from the beginning of the first millennium AD. In other words, inscriptional and archaeological data have now been put together that indicate that the coastal areas of Sembiran and Pacung could have been the earliest harbour in northeastern Bali. Geographically, Sembiran and Pacung could be part of ancient Julah, as has been mentioned in several Balinese inscriptions. 


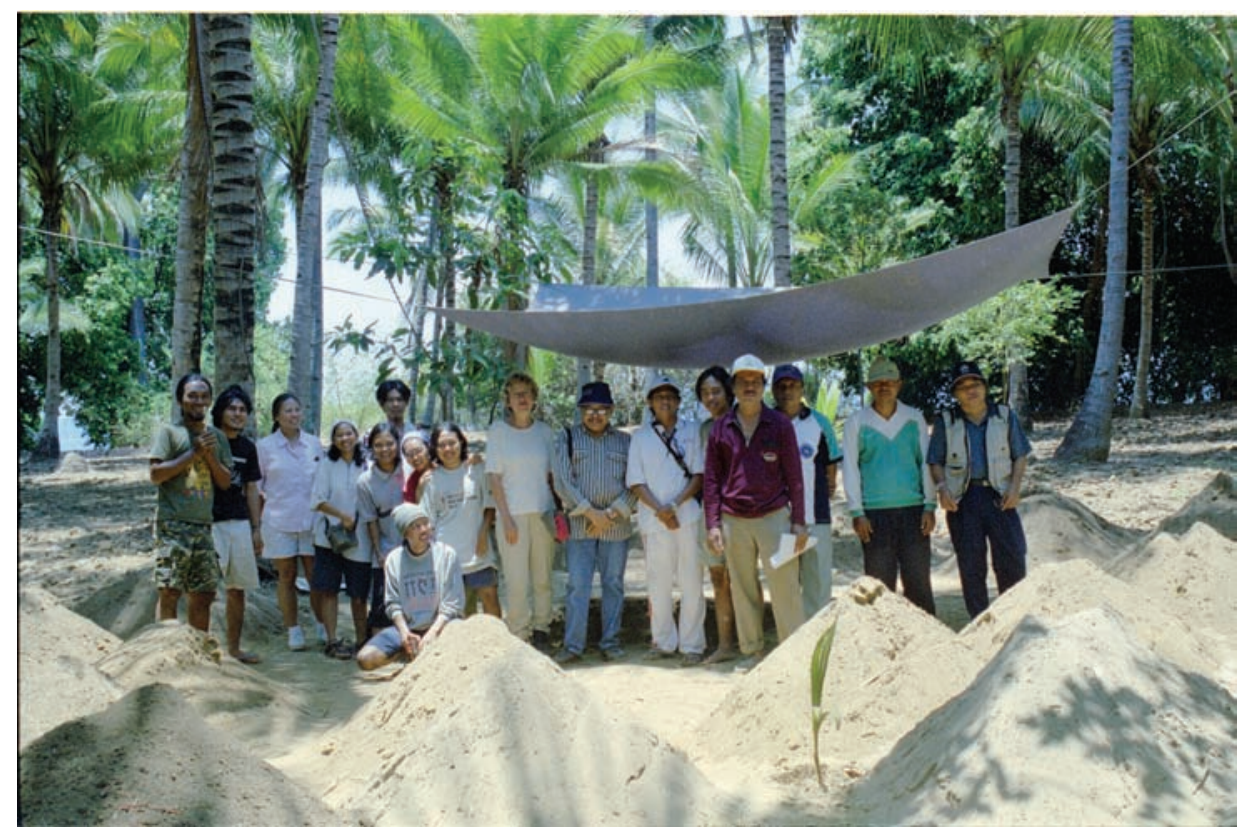

Photo 1: The excavation team (with the two editors of this book in the centre) in Pacung in 2003.

Photo: Jörg Hauser 2003.

\section{Archaeological Discoveries}

Over the last decade, archaeological excavations on the north-eastern coast of Bali, particularly at the sites of Sembiran and Pacung have been continued.

These excavations have produced a large amount of Indian pottery including Rouletted Ware of Arikamedu type 1, potsherds of Arikamedu type 10, a potsherd of Arikamedu type 18, and a potsherd of Arikamedu type 141, named after the archaeological site in the Coromandel Coast, Tamil Nadu (India), a once important port with intermaritime trade relations reaching as far as the Mediterranean Sea and the Roman Empire. So far, Sembiran and Pacung have produced the largest collection of rouletted sherds in Indonesia and Southeast Asia. More than a hundred pieces of rouletted sherds were discovered at Sembiran and Pacung (Ardika 1991). A complete bowl of Rouletted Ware has also been found accidentally at Kobak Kendal in West Java. This site is considered to have been the former site of Taruma Negara kingdom in West Java.

Rouletted Ware was manufactured in India or Sri Lanka between perhaps 150 BC and AD 200. The date of appearance of Rouletted Ware in Bali and Indonesia in general was probably AD 1-200 (Ardika and Bellwood 1991:229). It should be noted that a large black-slipped storage jar was tempered with rice husk found at 
the same layer in association with Rouletted Ware at Sembiran dated by AMS radiocarbon to 2660+/- $100 \mathrm{BP}$ (Ardika and Bellwood 1991).

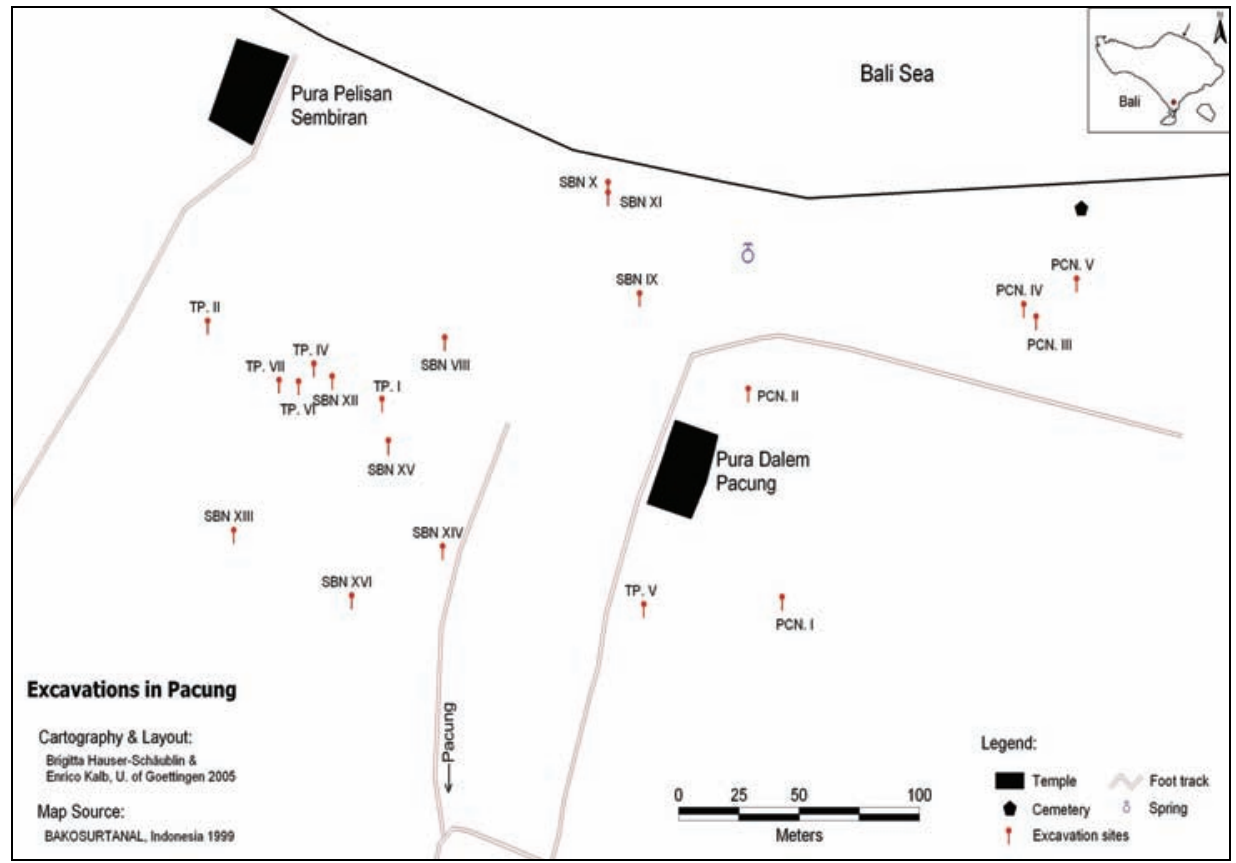

Figure 1: The location of the individual excavations trenches in Pacung.

X-ray diffraction (XRD) analysis has so far been performed on one rouletted sherd from Sembiran IV, four from Anuradhapura and three from Arikamedu. All have essentially the same minerals; mainly quartz with traces of mica, muscovite, potassium feldspar and plagioclase feldspar. The XRD result conclusively supports an Indian origin (Ardika and Bellwood 1991:224; Ardika et al.1993).

In addition to the XRD analysis, nine samples of Rouletted Ware (two from Anuradhapura, two from Arikamedu, one from Karaikadu [Tamil Nadu], three from Sembiran and the single sherd from Pacung) have also been subjected to neutron activation analysis (NAA) for 20 rare elements. The result indicates that all the Rouletted Ware is so similar in composition that a single manufacturing source for all the samples listed has to be supposed. The rouletted sherds cluster completely and separately in principal components and average link cluster analysis from those of presumed Balinese manufacture (Ardika and Bellwood 1991:224; Ardika et al.1993).

Apart from Rouletted Ware, two pieces of sherds of Arikamedu type 10 have also been found at Sembiran. Outside Arikamedu this type of pottery has also been found on the site of Chandraketugarh in West Bengal, and Alangankulam on 
the Vaigai river in Tamil Nadu (Ardika and Bellwood 1991:224). No information is at present available on its occurrence elsewhere.

An inscribed sherd has also been discovered at Sembiran (Ardika and Bellwood 1991:225, fig.4). At first the script was believed to be Brahmi, similar to that used for the Tamil or Prakrit graffiti found on many potsherds from South Indian sites such as Arikamedu, Anuradhapura, and Salihundam. However, according to B.N. Mukherjee of Calcutta University, the script is Kharoshthi, although no definite translation is possible owing to the fragmentary nature of the script.

Beads made of glass or stone were often found in several prehistoric sites in Indonesia. Red glass beads or mutisalah are very common in Southeast Asia as well as in Indonesia. Several sites such as Oc-Eo (Vietnam), Kuala Selinsing and Pangkalan Bujang (Malaysia) produced a large number of glass beads, but are very rare at Ahichchatra, North India. Glass beads were also found in several sites in Indonesia, including Gilimanuk, Sembiran (both sites in Bali), Plawangan (Central Java), Leang Bua (Flores), and Pasemah (South Sumatra). Five glass beads from Sembiran have been analysed by Kishor Basa at the Institute of Archaeology in London. One can be categorized as mixed-alkali glass and four as potash glass. Basa (1991) believes that the Sembiran beads are similar to South Indian samples in terms of raw materials, and were probably manufactured at Arikamedu.

In addition to glass beads, carnelian beads have also been discovered in several prehistoric sites such as Gilimanuk, Sembiran and sarcophagus sites (Nongan, Bona, Selasih, Margatengah, Pujungan, and Ambiarsari) in Bali. These carnelian beads are generally believed to have been imported from India, although some may have been made in Southeast Asia since carnelian scrap occurs in some sites, including Kuala Selinsing in West Malaysia.

Gold foil eye covers have been found in Gilimanuk and in sarcophagus burial sites at Pangkungliplip and Margatengah (Soejono 1977). Similar gold foil eye covers have also been discovered at Oton on Panay Island in the Philippines and at Santubong in Sarawak (O'Connor and Harrisson 1971:72-73). These gold foil eye covers are similar to the artifacts reported from graves at Adichanallur on the Tamil Nadu coast (O’Connor and Harrisson 1971; Ray 1989:51).

Apart from Indian articles, glass and stone beads, as well as metal objects, the majority of archaeological findings in north-eastern Bali are potsherds. These potsherds are very similar in terms of form and decoration to those found in a number of contemporary sites in Southeast Asia. This type of pottery in Southeast Asia is well known as Sa Huyn (Vietnam) - Kalanay (The Phillipines) pottery.

Human burial sites have also been found in several trenches at Sembiran and Pacung. Burial practices at Sembiran and Pacung seem to have consisted of two types, namely primary and secondary burial. In primary burial the corpse was normally put in the ground without a permanent container, and in straight or bent position. In secondary burial, it was sometimes put in a pot used as a container, or 
without a container. Burial accoutrements consisted of potteries, glass and carnelian beads, stone tools, as well as metal objects.

From the year of 1987 up to 2005, there are at least 32 trenches that have been excavated in several villages in north-eastern Bali, including 1 trench at Julah, 7 trenches at Pacung, 20 trenches at Sembiran, 2 trenches at Upit/Batu Gambir, and 2 trenches at Bangkah. These trenches are mainly $1.5 \times 1.5 \mathrm{~m}$ or $2 \times 2 \mathrm{~m}$ in length and between 1.5 and $4.5 \mathrm{~m}$ in depth. Most of the archaeological evidence has been found in the coastal areas of Julah, Pacung, Sembiran, and Bangkah. Only a few potsherds have been found from two trenches that were excavated in the highlands of Sembiran (Sembiran Atas/SBA 1 and 2). The situation is similar at Upit/Batu Gambir. However, there are only small numbers of potsherds that were discovered during the excavation programs at Upit/Batu Gambir. On the basis of archaeological remains it can be assumed that the settlement in northeastern Bali might have been located in the coastal areas, due to geographical setting of north-eastern Bali, which is located on the trade routes connecting the eastern and western part of the Indonesian archipelago.

\section{Trade and Trade Goods}

Archaeological evidence such as Rouletted Ware, glass and carnelian beads and gold foil eye covers, discovered in several prehistoric sites in Indonesia, might have derived from India. The question arises as to what kind of goods or commodities from Indonesia or Southeast Asia were exported to India during prehistoric times; we have so far no definitive answer to this, however the following indications:

High-tin bronze bowls, made in Southeast Asia perhaps as early as 200 BC, might have been exported to India and even as far as Taxila in Pakistan (Glover 1990). Pottery decorated with intricate angular or curvilinear carved-paddle impressed designs, of a type very common throughout at least the past 2000 years in western Island Southeast Asia has also been found in major Indian trading sites of the early historical period such as Arikamedu, Anuradhapura and probably Kantarodai. The finds in India cannot however be assumed to be from Southeast Asian sources without the benefit of chemical analysis (Ardika and Bellwood 1991:230).

It is remarkable to note that both Indian and Classical sources mentioned a number of products from Indonesia. For instances, the Ramayana (prior to AD 200) mentions gharuwood and sandalwood from eastern Indonesia, where the best quality sandalwood was to be found. The Raghuvamsa of Kalidasa (AD 400) mentions cloves (lavanga) with nutmegs indigenous to the Moluccas (Wolters 1967:65-6). Miller (1969) provides detailed list of spices mentioned in Classical texts which are presumed to have been produced in Southeast Asia during the Roman Imperial period. Cloves were known to Pliny in AD 70 (Miller 1969:51), as 
was cinnamon, which probably was grown widely in Sri Lanka and Island Southeast Asia at that time.

It is interesting to note the result of the analysis of ancient mitochondrial DNA from the human tooth of Pacung III in north-eastern Bali. The tooth sample is generally associated with haplogroup $\mathrm{A}$, which clearly clustered closest to Indian sequences followed by most of the Nepalese and Tibetan sequences (i.e., 16240 G, $16261 \mathrm{~T}$ ) (Lansing et al. 2004:288-90). AMS radiocarbon analysis of the tooth indicates its age as 2050 +/- $40 \mathrm{BP}$ (conventional radiocarbon age 2110 +/40 BP) (Lansing et al. 2004:288). In addition, Y-Chromosome data from a sample of 551 modern Balinese men indicate significant prehistoric contacts between India and Bali (Karafet et al. 2005).

On the basis of archaeological data found at Sembiran and Pacung, we can assume that both sites which are very close to each other could be part of an ancient harbour on the north-eastern coast of Bali. In the beginning of the first millennium $\mathrm{AD}$, foreign traders might have come to the site with their goods such as Indian pottery, beads of glass and carnelian, and possibly other products. Foreign traders might have died and been buried in the site or intermarried to local people as indicated by the DNA results from Pacung.

Since archaeological data is still limited, it is impossible to know whether the Balinese or Indonesian traders also travelled to the Indian continent at the beginning of our century. This kind of question needs to be raised in order to understand the mechanisms and processes of trade between foreigners and the local people of Bali in the past.

As mentioned before, all the evidence indicates that Sembiran and adjacent areas could have been a harbour on the north-eastern coast of Bali dating from the beginning of the first millennium AD up to $12^{\text {th }}$ century AD. Sembiran might have been located on the trade route between eastern and western part of the Indonesian archipelago. It is not clear why the site ceased functioning as a harbour after $12^{\text {th }}$ century AD. Archaeological excavations at Sembiran and Pacung suggest that the erosion and sedimentation process reached a depth of 4 meters within 2000 years. This erosion and sedimentation process could be another factor besides social disturbance that caused the end of Sembiran harbour in north-eastern Bali after $12^{\text {th }}$ century.

\section{Conclusion}

Archaeological and inscriptional data suggest that Sembiran or the ancient village territory of Julah could have been one of the ancient harbour in north-eastern Bali. Trade activities might have taken place in a market place within a fortified settlement. DNA analysis indicates that foreign traders presumably may have come to the site and intermarried with local people. Genetic data also strongly suggest the presence of contacts between India and Indonesia, and particularly 
Bali, during prehistoric times. These contacts supposedly have been stimulated by the appearance of a world trade system in these regions (Glover 1990).

\section{References}

Ardika, I Wayan

1991 Archaeological Research in Northeastern Bali, Indonesia. Dissertation. Canberra: Australian National University.

Ardika, I W. and P. Bellwood

1991 Sembiran: the Beginnings of Indian Contact with Bali. Antiquity 65, 247: 221232.

Ardika, I W., Bellwood, P., Eggleton, R.A. and D.J. Ellis

1993 Single Source for South Asian Export-Quality Rouletted Ware. Man and Environment XVIII, 1 (January-June): 101-109.

Ardika, I W., Bellwood P.S., Sutaba, I.M. and K. Citha Yuliathi

1997 Sembiran and the First Indian Contacts with Bali: an Update. Antiquity 71, 271: 193-195.

Barret Jones, A.M.

1984 Early Tenth Century Java from the Inscriptions. Leiden: Koninklijk Instituut voor Taal-, Land- en Volkenkunde.

Basa, K.

1991 The Westerly Trade of Southeast from c. 400 BC to AD 500 with Special Reference to Glass Beads. Unpublished Ph.D. Thesis. London: University of London.

Glover, I.C.

1990 Early Trade Between India and Southeast Asia. Link in the Development of a World Trading System. Hull: Centre for Southeas Asian Studies. The University of Hull.

Goris, R.

1954 Prasasti Bali. Lembaga Bahasa dan Budaya. Fakultas Sastra dan Filsafat, Universitas Indonesia. Bandung: Masa Baru.

Karafet, T.M. et al.

2005 Balinese Y-Chromosome Perspective on the Peopling of Indonesia: Genetic Contributions from Pre-Neolithic Hunter-Gatherers, Austronesian Farmers and Indian Traders. Human Biology 77, 1: 93-113.

Lansing, J.S., Redd, A.J., Karafet, T.M., Watkins J., W. Ardika et al.

2004 An Indian Trader in Ancient Bali? Antiquity 78, 300: 287-293.

Miller, J.I.

1969 The Spice Trade of the Roman Empire. Oxford: Clarendon. 
O'Connor, S.J. and T. Harrisson

1971 Gold-foil Burial Amulets in Bali, Philippines and Borneo. Journal of Malaysian Branch of the Royal Asiatic Society 44, 1: 71-77.

Ray, H.P.

1989 Early Maritime Contacts between South and Southeast Asia. Journal of Southeast Asian Studies XX, 1: 42-54.

1994 The Winds of Change. Buddhism and the Maritime Links of Early South Asia. Delhi: Oxford University Press.

Soejono, R.P.

1977 Sistem-Sistem Penguburan pada Akhir Masa Prasejarah di Bali. Unpublished Dissertation. Jakarta: University of Udayana.

Wheeler, R.E.M., Ghosh, A. and Krishna Deva

1946 Arikamedu: an Indo-Roman Trading Station on the East Coast of India. Ancient India 2: 17-124.

Wisseman-Christie, J.

1977 Market and Trade in Pre-Majapahit Java. In: Hutterer, K.L. (ed): Economic Exchange and Social Interaction in Southeast Asia: Perspectives from Prehistory, History, and Ethnography; pp. 108-118. Michigan Papers on South and Southeast Asia, Vol. 13. Ann Arbor: The University of Michigan.

Wolters, O.W.

1967 Early Indonesian Commerce. Ithaca \& London: Cornell University Press. 



\title{
Traces of Human Life Style from the Palaeolithic Era to the Beginning of the First Century AD
}

\author{
I Made Suastika
}

\section{Introduction}

The Importance of the Archaeological Research in North Bali

Prehistoric life in Bali can be characterized as a life of hunters and gatherers. This description is based on the cultural evidence known to have been Palaeolithic, in the form of solid tools discovered around Lake Batur, Trunyan, Kintamani, Sembiran, Pacung, Julah, and Bondalem (Soejono 1984:107; Suastika 2000a). Although the material evidence has been discovered, the people who supported the culture and who created the solid stone tools have so far not been identified.

It seems that there was continuous life in Bali as far as can be deduced from the natural caves used as settlements. Traces of Mesolithic culture have been identified from discoveries made in the cave at Selonding, Pecatu. The tools are of bones and horn; nothing is known, however, of the people who made them (Soejono 1984:98). In addition to the cave at Selonding I recently discovered some caves on Nusa Penida. The excavations in the Goa Gede there showed two cultural layers of the hunting and gathering continuum, together with an additional layer of cultivation. In the agricultural layer some C14 dating has been carried out, in cooperation with Brigitta Hauser-Schäublin, Institute for Cultural and Social Anthropology, University of Goettingen, and P. M. Grootes, Leibniz Laboratory 
for Radiometric Dating and Stable Isotope Research, Kiel, which has produced dating of $3805 \pm 25$ BP (Suastika 2005).

With the beginning of agriculture, people started living permanently in small settlements. Agriculture and the pattern of living permanently in small settlements contributed to an increasing population density, the development of a clan-based society and elaborate forms of cooperation in the cultivation of agricultural land as well as complex activities relating to death and worship in general. Forms of worship such as the menhir (a big stone post as a megalithic cultural product symbolizing the ancestor's soul), the stone seat (the "king's chair" made of stone), statues and other megalithic monuments were developed in honour of the ancestors. As other excavations along the north coast of Bali have shown, the megalithic tradition appeared in the agricultural farming period and continued to develop to the Bronze-Iron Age (perundagian) up to the present day (Heekeren 1958; Soejono 1982; Sukendar 1993; Sutaba 1976).

Pacung is one of the archaeological sites located in the north-eastern coastal area of Bali. Like other ancient villages such as Bangkah, Julah, Sembiran, Bondalem, Tejakula, Les and Penutukan, Pacung has unique traditions manifested in its worship system, its form of social organization, the rules governing social life and the ancient artefacts that have been discovered there

This paper will discuss the above-mentioned traces of human life based on the archaeological research carried out at Pacung and its surroundings.

The archaeological research in North Bali has been crucial for the development of archaeology as a discipline in Indonesia in general and in Bali in particular. The results gave evidence of Bali's long history predating the establishment of Dutch colonial rule by centuries, even millennia; the results, therefore, have proved to be an important contribution to Bali's identity. The archaeological research started with the deciphering of inscriptions kept at Sembiran by R. Goris (1954). In 1961 R.P. Soejono conducted research at Sembiran and excavated some Palaeolithic tools (Soejono 1962:225).

A few years later, I Made Sutaba discovered some megalithic buildings there, which he interpreted as prehistoric in origin. At about the same time, I Wayan Widia investigated a bronze kettledrum, nekara, used in religious ceremonies during the Bronze Era decorated with an eleven-sided star; this kettledrum was $84 \mathrm{~cm}$ high and had a diameter of $62 \mathrm{~cm}$. This important artefact, whose whereabouts are unclear today, was found by chance by some inhabitants at Pacung village. This drum has been identified as belonging to the same type as the existing at Pejeng (Widia 1981). Then, in 1987 I Wayan Ardika started excavations at Bangkah, Pacung and Sembiran. His research produced a wealth of data, among them sherds of local pottery and foreign ceramics, fragments of a kettledrum, beads, and so on (Ardika 1989). Since then researchers have paid so much attention to the site that it has even been used as a training field for students, through cooperation between 
the Archaeological Office of Denpasar and the Faculty of Letters, Udayana University, a project intensified since 1990.

In addition, archaeometric research was conducted by the National Archaeological Research Centre of Jakarta in 1995 under the leadership of the archaeologist Sudiono in order to establish the relationship between the cultural and the environmental variables so that the choice and the location of Sembiran as the settlement location in the past could be reconstructed. After 1995 the research was continued by the Department of Archaeology, the Faculty of Letters at Udayana University, in cooperation with the National Archaeological Research Centre through the Archaeology Office at Denpasar.

From the typology of findings, their stratigraphic location and comparison with similar findings in other regions, we can conclude that the north-eastern coast had been inhabited since the Neolitihic (perundagian) that is, from the first Millennium BC to the first century AD (Sudiono and Arfian 1995). The excavation campaigns mentioned above have produced many archaeological remains. Various Palaeolithic tools, so-called choppers and smaller tools, flakes and blades (serpin bilab), various kinds of pottery sherds of both local and foreign origin (made in India), a large variety of beads, bronze fragments of kettledrums, human remains and animal bones, stone seats ("king's chair"), statues, stone piles, and sarcophagi. Still, many of the archaeological artefacts and the cultural context they come from need further study and interpretation.

\section{The Location of Pacung}

Morphologically, the northern part of Bali is divided into three regions: the coastal region, the mainland region and the hilly region (Figure 1).

Administratively, Pacung village belongs to Tejakula District, Buleleng Regency. The site can be reached easily by any means of transport. It is 26 kilometres from Singaraja city, or 112 kilometres from Denpasar city. Geographically, reckoned from the meridian spot in Jakarta, the position of the site is $8^{\circ} 7^{\prime} 57^{\prime \prime}$ to $8^{\circ} 11^{\prime} 42^{\prime \prime}$ South Latitude and $115^{\circ} 12^{\prime} 30^{\prime \prime}$ to $115^{\circ} 15^{\prime} 49^{\prime \prime}$ East Longitude and 0 - 350 metres above sea level.

Pacung is situated on a narrow strip of land between the mountains and the sea. The soil is brown and yellow in colour. Water is available only near the coast; rice cultivation is not possible. Geologically, the substratum consists of tuff stones, and the sediment of old Buyan and Beratan lava composed of lava, breccia and tuff that had erupted from Mount Kalatakan, Mount Merbuk and Mount Patas (West Bali) (for a geological map of Northeast Bali see Kalb, this volume, Figure 3).

The environmental conditions are so bare that land conservation today is not possible in the way as on the hills with dense forest. Mountains without forest as a binding agent are prone to high erosion during the wet season. This has been evidenced by the floods and landslides that frequently strike the inhabitants' 
houses. Due to these conditions, most villagers in Pacung village and its surroundings currently work as farmers cultivating dry fields or gardens. Some also work as traders and fishermen.

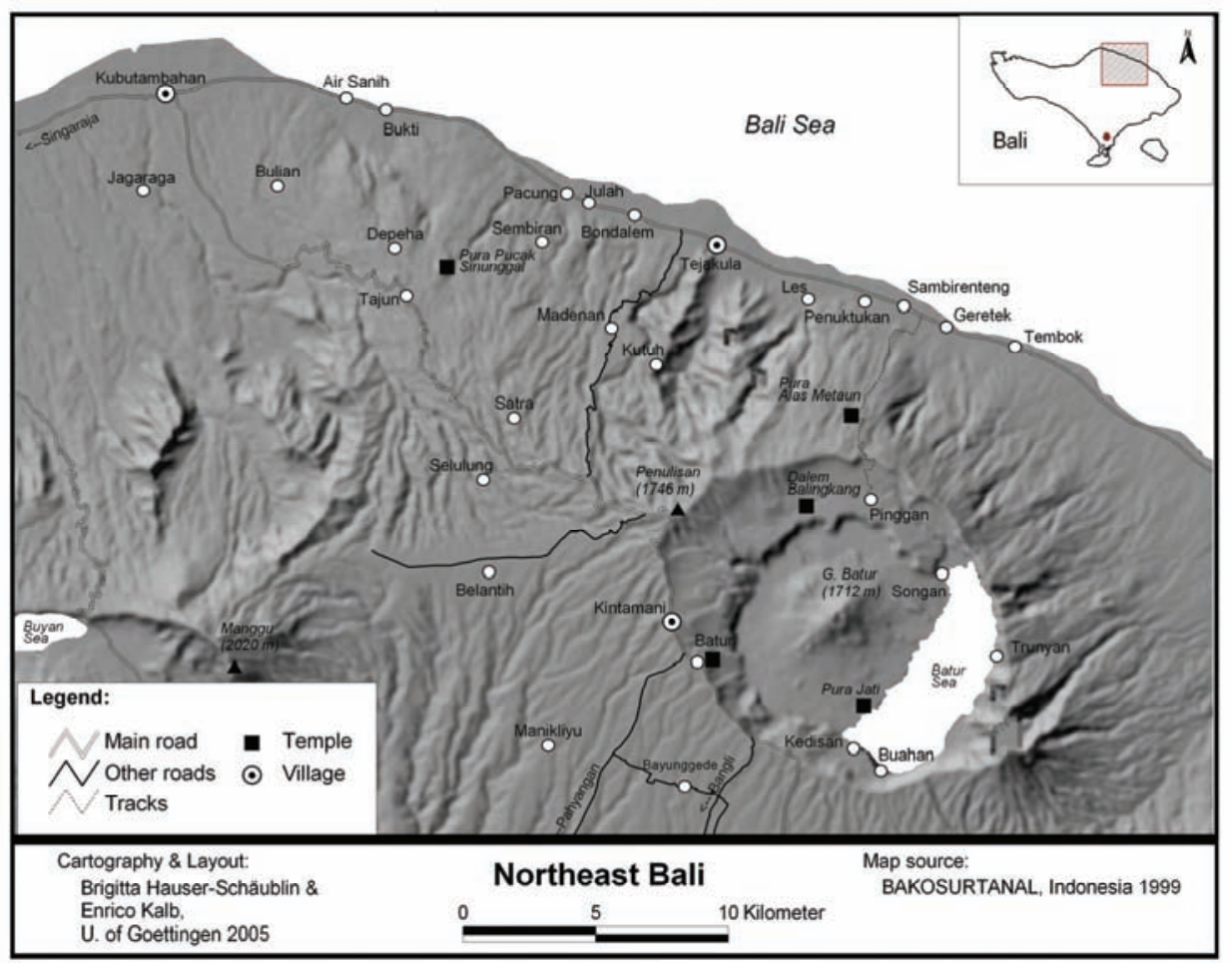

Figure 1: Northeast relief of Bali with the huge crater and caldera of the Batur volcano.

\section{The Results of the Excavation at Pacung}

The Oldest Traces of Human Life

Natural conditions supporting human life during the Pleistocene Era that commenced from 2.500 .000 to about 10.000 years ago were marked by major incidents affecting human life. Such incidents included the expansion of ice on the earth's surface, the fluctuation of sea level, volcanic eruptions, and the appearance and disappearance of rivers and lakes.

In Indonesia the Pleistocene Era is chronologically divided into the formations of Pucangan (Earlier Pleistocene; named after a location in eastern-central Java), Kabuh (Middle Pleistocene) and Notopuro (Upper Pleistocene). These eras are clas- 
sified as the hunting and food collecting periods which occurred from 1.9 million to 10.000 million years ago (Soejono 1976:20). Excavations at Sangiran (Central Java) proved that Homo erectus dominated this region from the Earlier Pleistocene to Middle Pleistocene. This period of time corresponds to 1.3 to 0.2 million years ago (Widianto et al. 1998:1). Nevertheless, natural conditions from the earliest era of mankind in Indonesia, the Pleistocene, were favourable for these forebearers of modern man. The people lived in groups and subsisted from hunting and gathering; they made and used all kinds of Palaeolithic tools including heavy ones ("pebbles"), flakes, bones, antler tool, and wooden ones.

In the Palaeolithic tradition there are two well-known basic forms. These are stone tools called choppers (a kind of axe) and flakes (Soejono et al. 1984:84). Basically, the method by which choppers were produced was unifacial, combining both solid and rough characteristics. Similarly, the flakes seldom show a point of percussion or a striking platform (Heekeren 1955:11).

In Indonesia the Palaeolithic tools were mostly stone tools which are typologically similar to those wide-spread in other parts of Southeast Asia and East Asia. They developed in the regions that had a lot of stone materials suitable for producing tools. This can be seen in the regions where Palaeolithic developed in Indonesia such as in Java, Sumatra, Nias, Kalimantan, Sulawesi, Lombok, Sumbawa, Flores, Timor, Sabu and Sumba. In Bali Palaeolithic stone tools were discovered around Lake Batur, Sembiran, Julah and Pacung.

Geologically, the mountainous area in North Bali is an extension of the Solo Zone in Java. This zone is a volcanic belt that formed after the Lower Pleistocene Era and is still active today. The Mount Batur complex is actually a big crater formed by volcanic eruptions resulting in two crater rims (caldera) including the ridge on which Sembiran is situated. Many Palaeolithic tools have been discovered on this ridge, which includes Pacung and Julah villages. Research on Palaeolithic tools was first conducted by R.P. Soejono, who made a typological classification of the tools (Soejono 1962). In 1990 I conducted further research at Sembiran, Pacung and Julah. I found Palaeolithic tools in different locations, such as at the lower and the upper parts of the River Panggang, near Sembiran and close to the river Kayehan Kangin, also along a path near Julah and in the lowland plain close to Pacung.

By means of technological analysis I was able to classify them as: chopper (both general and iron type), chopping tool, proto hand axe, hand adze, hand axe, high scraper, and another kind of scraper, hammer and various other tools (Suastika 2000a; 2000b).

Compared with other Palaeolithic sites in Indonesia, the Pacitan Palaeolithic tools (named after a village in south-central Java) are the best both quantitatively and qualitatively. Pacitan Palaeolithic tools showed a development of both the solid sort (choppers) and flakes, which were classified by Movius (1948). Technologically, van Heekeren (1922:3) believed that the tools found in Pacitan were 
flakes struck from cores (Bellwood 1985:60-63). After striking one stone against another or throwing one stone against a bigger one, the so-called "smashing technique", the good and suitable fragments were selected to be used as tools. This technique seems to have been already widely used in the Palaeolithic Era. The tools found at Pacung and Sembiran are of the same type. The stone tools are simple in form and are roughly trimmed. More developed types of tools have not been discovered at Pacung so far. The reason for this may be that the stone material in Sembiran and its surroundings is rougher and harder than the stone found at Pacitan.

In 1990 I collected a number of Palaeolithic tools found spread over Pacung, Sembiran and Julah, which are in the form of solid tools including choppers, scrapers, chopping tools, hand adzes, proto hand axes, hand axes, axes of a horsehoof type, hammers and core (Table 1).

Table 1: The Range of Palaeolithic Tools Found at the Pacung Site

\begin{tabular}{|l|l|l|l|l|l|l|l|l|l|}
\hline Location & Chopper & $\begin{array}{l}\text { Hand } \\
\text { axe }\end{array}$ & $\begin{array}{l}\text { Hand } \\
\text { adze }\end{array}$ & $\begin{array}{l}\text { Chop- } \\
\text { ping tool }\end{array}$ & Scraper & Flake & Core & $\begin{array}{l}\text { Ham- } \\
\text { mer }\end{array}$ & $\begin{array}{l}\text { Oth- } \\
\text { ers }\end{array}$ \\
\hline $\begin{array}{l}\text { Pacung } \\
\text { village }\end{array}$ & 10 & 2 & 2 & 2 & 8 & 5 & - & 1 & 30 \\
\hline $\begin{array}{l}\text { Coastal } \\
\text { area }\end{array}$ & 6 & 9 & 2 & 2 & 9 & 1 & 2 & - & 31 \\
\hline $\begin{array}{l}\text { Sembiran } \\
\text { village }\end{array}$ & 9 & 3 & 2 & 1 & 6 & - & 2 & - & 23 \\
\hline $\begin{array}{l}\text { Julah } \\
\text { village }\end{array}$ & 3 & 6 & 1 & 1 & 6 & 2 & - & - & 19 \\
\hline Total & 28 & 20 & 7 & 6 & 29 & 8 & 4 & 1 & 103 \\
\hline
\end{tabular}

The Palaeolithic tools are dominated by choppers. Among them, 14 are of the horse-hoof type. Their characteristics are as follows: the material is basalt stone black in colour, the sharpened part is semi-circular and made by upright trimming, and the outer layer of the stone is sometimes left on the surface. In addition to the choppers of the horse-hoof type, four items of the iron types are also found. Their characteristics are as follows: they are long, plano-convex cross-section, strictly trimmed and stretched. On the sharpened part, marks of frequent use can be seen. Marks of use are also seen on the other tools such as on chopping tools, hand axes and hand adzes (Suastika 1990:5).

\section{Neolithic Evidence}

Human life in the Agricultural Era (Neolithics) - starting about 5000 years ago was, as in other parts of the world, a more developed level (Ardika 1987, Ardika 
and Sutaba 1996). The tools were well made, polished and und rubbed to make them soft and sometimes shiny.

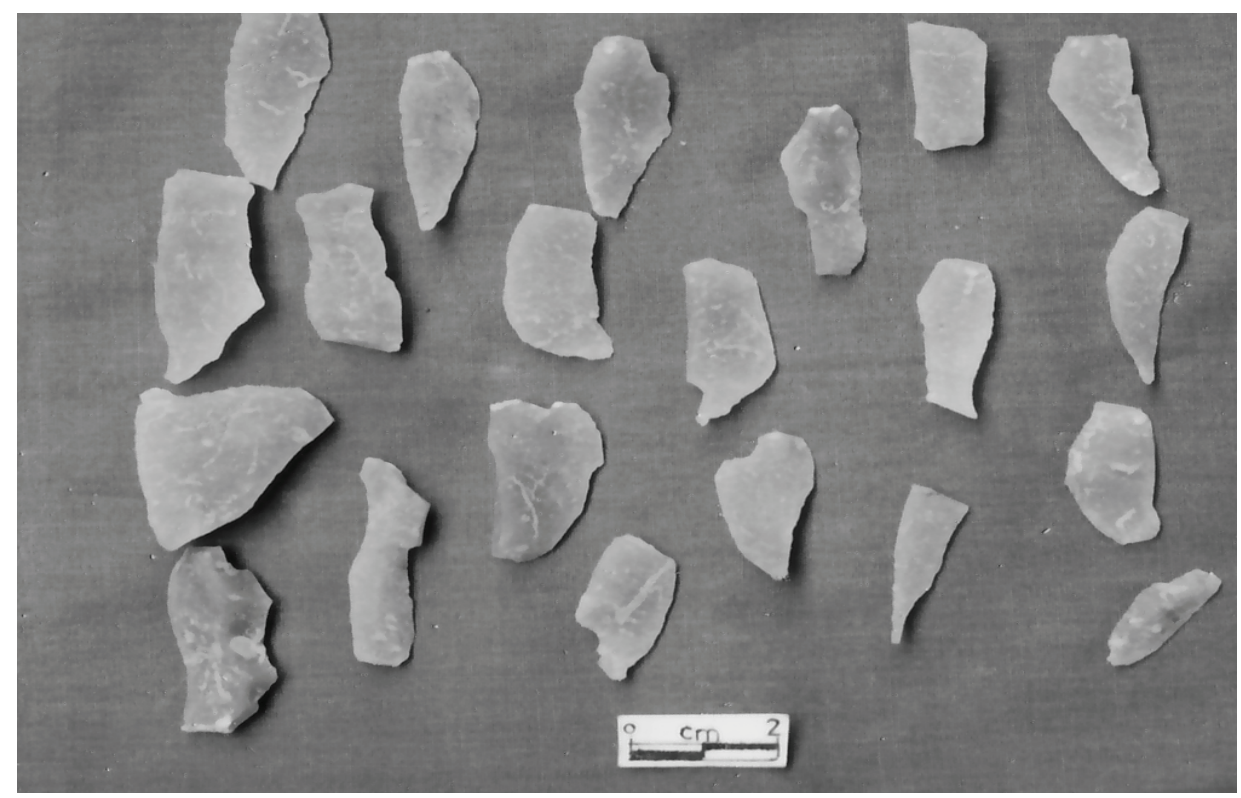

Photo 1: Flakes and blades used as grave goods, Pacung excavation. Photo: IMade Suastika

The Neolithic or Agricultural Era coincided with the development of expertise in polishing stone tools and pottery production. The surface finding of a one-sided hatchet, polished on all sides, is an interesting example. It is rectangular with a sharpened monofacial edge. In addition, obsidian tools, employed as grave goods, were found at Bondalem beach. On one of the skeletons in Pacung, which followed the system of burial without containers, the head was directed mountainward and the feet towards the sea. Near the shoulders 21 obsidian flakes and blades were found and on the feet one clay pot (Sudiono and Arfian 1995:21). The core flakes in Indonesia had appeared after the Mesolithic Era, but at the Pacung site these tools were associated with pottery used as grave goods. This clearly reveals that flakes played an important role during the Cultivation Era, too. The skeleton found was incomplete and in a fragile condition. The remains consisted of an upper and lower arm bone, and a left and right and upper right skin bone. The skull was damaged and the teeth incomplete. The position of the skeleton was five metres north of the shore edge, buried 210-260 centimetres below sea level. The analysis of the flakes and blades revealed slightly damaged edges, showing that the tools had been regularly used before. 
The excavations of graves containing human skeletons showed that the people living at different places along the coast, and also in Bondalem, had been familiar with the same burial system.

In the Pacung/Sembrian area, fragments of containers (of unknown use) had been found; there is however almost no documentation on these excavations. Most recently (in the late 1990s) a sarcophagus was discovered at the temple of Ponjok Batu during renovation works. However, most of these graves excavated along the coast between Pacung and Tejakula did not display any permanent container such as sarcophagi. The burials showed in each case no traces of containers and the corpse was stretched out. Not far from where the skeleton was found in Pacung, a burial jar with a lid, which first appeared when the sea level retreated, was also found. The jar was found damaged. The wall of the container is thin and blackish-brown in colour; there is no indication that the jar was produced by means of a rotating wheel. The lid is thick and yellowish-brown in colour. The diameter of the jar is $60-68 \mathrm{~cm}$ and the height is $40 \mathrm{~cm}$. The position of the jar was $2.80 \mathrm{~m}$ from the shore edge and $2.60 \mathrm{~m}$ below sea level. The jar contained an intact skull, human bones, teeth and burned pig bones. The jar burial (secondary burial) was located beside the primary one mentioned above. The association of flakes and blades, skeletons and pottery as grave goods suggest that these burials are not Mesolithic but Neolithic, since pottery is characteristic of Neolithic culture.

The fragments of pottery both of local and Indian origin are the most dominant artefacts found at the Pacung site. The fragments of local pottery consist of both simple and ornamented ones. They comprise the lip parts, the body, the base, the carination, and the pin and handle of a pitcher. The data used for the analysis were the findings in excavation Test Pit I and Test Pit II, which were excavated by the Archaeology Office of Denpasar, and those in Box I, II, III, IV and V, which were excavated by the Archaeology Department of the Faculty of Letters, Udayana University. 


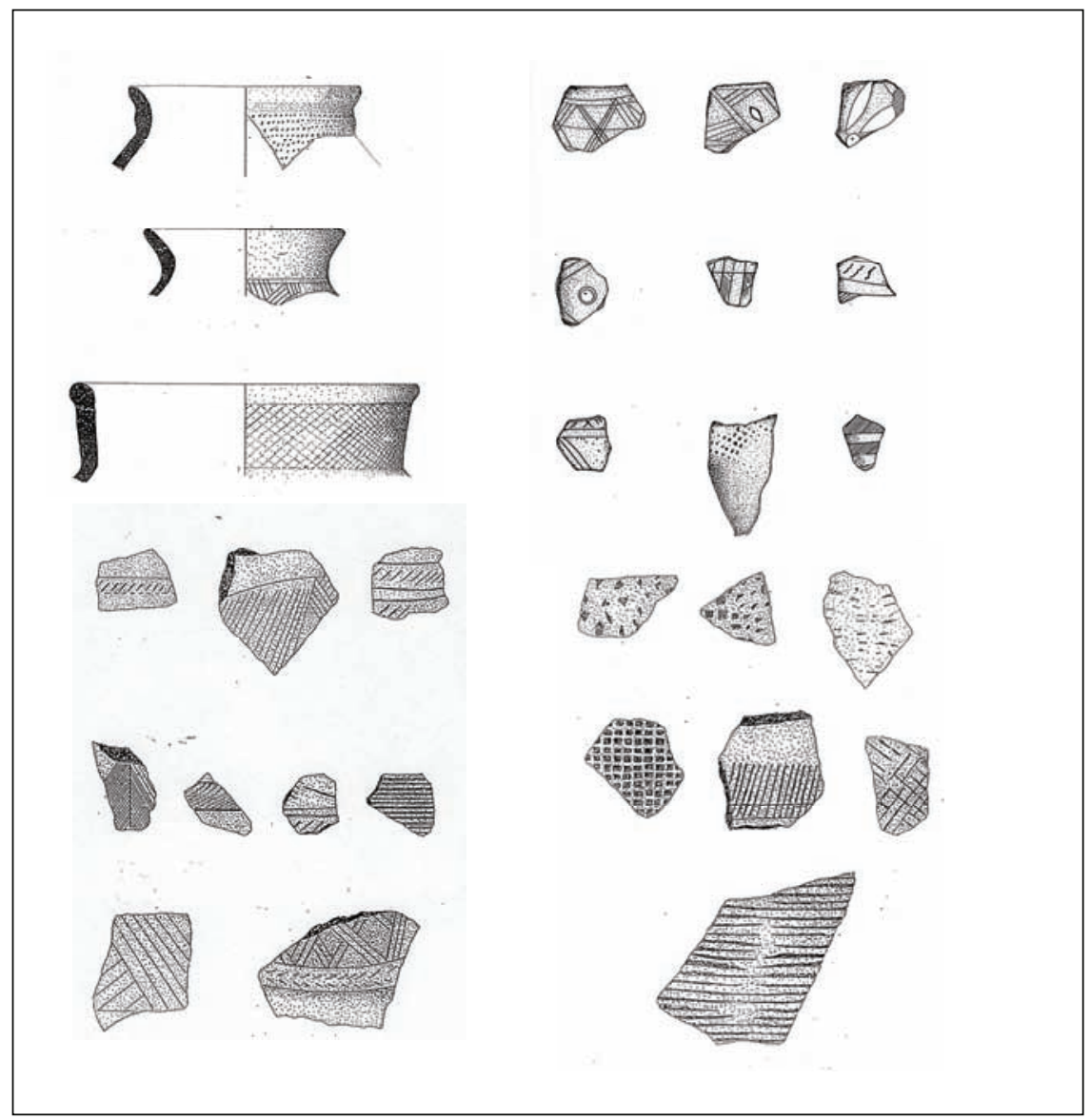

Figure 2: Pottery sherds displaying different techniques and styles of decoration, Pacung Site.

Drawing by Tim Jurusan Arkeologi 2004.

The findings of local pottery in Test Pit (TP) I amounted to 4.000 pieces, altogether consisting of pieces of simple pottery totalling 4.061 and ornamented ones totalling 339. The findings in Test Pit II amounted to 1.816, consisting of 1.731 pieces of simple pottery and 85 ornamented ones. Those in trench PCN I amounted to 2.342 , consisting of 2.326 fragments of simple pottery and 16 fragments of ornamented ones. Those in trench PCN II totalled 14.083, consisting of 13.146 fragments of simple pottery and 937 ornamented ones. In trench III, the fragments of pottery totalled 2.792, consisting of 2.507 fragments of simple pottery and 285 ones of ornamented pottery. Trench PCN IV contained 16.952 fragments of pottery, consisting of 16.068 fragments of simple pottery and 884 ones of ornamented pottery. Trench PCN V contained 292 fragments, 209 of which were of 
simple pottery and 83 of ornamented pottery. The total amount of the findings was 42.277 , with fragments of simple pottery (table 2) predominant.

Table 2: Distribution of Findings of Local Pottery, Pacung Site, Buleleng

\begin{tabular}{|c|c|c|c|c|}
\hline \multirow{2}{*}{ Number } & \multirow{2}{*}{ Trench } & \multicolumn{2}{|c|}{ Fragments of Local Pottery } & \multirow{2}{*}{ Total } \\
\cline { 3 - 4 } & TP I & Simple & Ornamented & 4,061 \\
\hline 1 & TP II & 1,731 & 339 & 45 \\
\hline 2 & PCN I & 2,326 & 16 & 1,816 \\
\hline 3 & PCN II & 13,146 & 937 & 2,342 \\
\hline 4 & PCN III & 2,507 & 285 & 14,083 \\
\hline 5 & PCN IV & 6,068 & 884 & 16,792 \\
\hline 6 & PCN V & 209 & 83 & 2952 \\
\hline 7 & Total & 40,028 & 2629 & 42,277 \\
\hline
\end{tabular}

The techniques of making ornaments on the pottery at Pacung were the impressed technique (paddle-impressed and dentate stamped), the incised technique and the excised technique. The ornamental patterns varied. Some were in the form of repeated circles, some were in the form of straight lines, some were in zigzag, lozenges, and others were in the form of curved lines, fish bones, rectangles, or a combination of all types.

The varied ornamental patterns on the local pottery are highly artistic. The ornamental patterns are similar to those found at burial sites in other parts of Bali such as Gilimanuk (Jembrana Regency), Manikliu (Bangli Regency) and Jambe (Tabanan Regency).

The Pacung site and its surroundings contain a large number of pieces of pottery brought from outside Bali, in particular India. The Indian pottery was also of various forms and contained fragments of Indian Rouletted Ware. Features of the latter were that the surface and the inside part of the wall were soft thanks to the advanced technique used in their manufacture. The core colour was light grey, brown, light orange and black. These features show similarity with rouletted pottery which was classified by Wheeler (1946) as "Arikamedu pottery type 1". The Neutron Activation Analysis (NAA) conducted by I Wayan Ardika shows that the fragments of Indian pottery are identical in composition to those of the Arikamedu, Karaikadu (both in South India) and Anuradhapura (Sri Lanka) type (Ardika 1991; Soegondo 2002:216-218).

In reconstructing the forms, types and functions of pottery all the parts of the pottery covering the lip, the rim, the neck, the body, the base, the carination, the lid and the spout, were subjected to analysis. Some of the Indian pottery consisted of ornamented or plain cups, bowls, pans and water jars, obviously intended for everyday use. 
Chemical analysis of the pottery found at Sembiran showed a composition of silica, calcium, sodium, magnesium, aluminium and sulphate (Ardika et al. 1996).

The beads found at Pacung were made of various materials such as stones, glass and fish bones. Among them, glass is the most dominant. Some were round, some were rectangular and the rest had a cylindrical form. Among them, the round ones were the most dominant. The colours also vary: some were white, some were blue, some were dark red, some were orange, some were greenish yellow and some were green with spots. Most beads were found in association with human skeletons and pottery.

Some of the bronze fragments found during the excavations at Pacung, Bangkah and Sembiran were fragments of kettledrums and of bronze bracelets. Some flat fish hooks with a hole in the middle, relatively small and made of bronze and iron with a diameter of $1.5 \mathrm{~cm}$ were also found. Other bronze fragments of kettledrums and bracelets were found in association with pottery fragments along the north-western coast of Bondalem. Three further bronze bracelets were also found at the Pacung site near a skeleton which was in a flexed position. A kapak corong (a kind of axe), whose handle was in bad condition, was found at a depth of 4.4 metres by some local people while digging a well at Pacung (Sudiono and Arfian 1995:21).

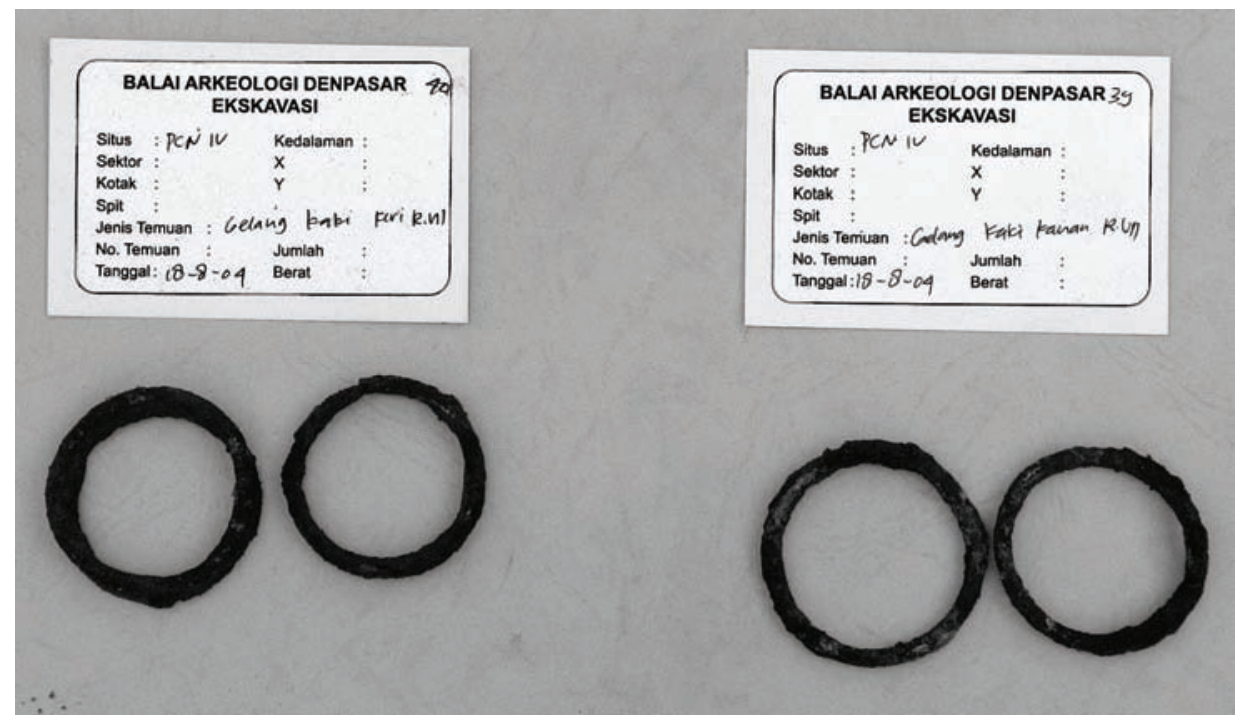

Photo 2: Bronze rings found at Pacung.

Photo: Jörg Hauser 2004.

The metal artefacts, especially those made of bronze, show that the coastal community living at Pacung was already familiar with bronze tools in their daily lives. Indeed, this was a feature of life in the first century AD. 
Apart from burials, a building foundation made of basalt gravel in trench $\mathrm{X}$ and trench XI was found at the Pacung site, too. The foundation shows a rectangular ground plan; the house was possibly built on wooden or bamboo poles.

A fireplace was found in trench II at the Sembiran site $30 \mathrm{~cm}$ below the surface. It was composed of four stones as supports. Fragments of an earthenware pan and charcoal were found surrounded by the stones. One earthenware pan containing betel lime at the edge of the fireplace was found, reminding us of the habit of keeping betel lime in a pan at the fireplace in the kitchen close to the drinking water container (Suantika 1991:35).

During the Neolithic Era, people resided permanently in villages and arranged their lives in accordance with their collective needs, which focused on how to manage a subsistence economy by means of both farming and animal husbandry. In the Bronze-Iron Age people developed the technique of forging metal for creating various tools. The progress achieved by people in improving their living standard led to a more complex structuring of society. The division of labour became more diverse with specialists for different tasks. Among them were undagi, craftsmen who specialized in various kinds of construction work, such as building wooden houses and producing goods made of pottery and other material as well (Soejono et al. 1984:238).

Further specialists produced canoes, bronze kettledrums, bronze hoes and so on. Metal technology developed fast at the beginning of the first century AD. This can be seen from the findings discovered by excavation and survey in the Pacung area; they all display features typical of the Bronze-Iron Age.

Agriculture became a more sophisticated activity, especially when the rice fields were supplied with water in order to set up irrigation agriculture and wet rice cultivation.

The organic remains found in the graves can be assumed to be the remains of human and animal bones. In addition to the fragments of bones some entire human skeletons were also found. Radiocarbon dating gives an estimated age of $2105 \mathrm{BP}$ for human bones found at a layer of $4,3 \mathrm{~m}$; as the tables (at the end of this chapter) show. The analyzing Laboratory added the comments: "The natural heavy $\delta{ }^{13} \mathrm{C}$-values may suggest a $\mathrm{C} 4$ [usually related to the consumption of crops such as millet, maize, sugar cane and others, but not rice], or a fish component in alimentation".

Furthermore, DNA laboratory analysis for a number of human teeth found at the Pacung site has already been done revealing that one of the human skeletons at the Pacung site displayed traces of probably north-east Indian ancestry. This was the skeleton of an adult female who lived 50 years before the first century AD. This strongly supports the assumption that Bali had been visited by Indians in person since the first centuries BC (Tim Jurusan Arkeologi 2003:46). Previously, scholars had debated the question whether the artefacts of Indian origin had reached Bali through indirect trade relations only. 
The Bronze-Iron Age was a so-called minor tradition which developed fast in Bali and continued up to the time when the influence of Hinduism, a major tradition, was introduced. The mix of the two traditions has resulted in the cultural tradition peculiar to Bali today.

\section{Summary}

Based on the data obtained from earlier research, excavations and surveys, it can be stated that the Pacung site has been continuously settled by humans since the Palaeolithic Era.

The flakes and blades, usually attributed to the Mesolithic Era, that were found in association with pottery sherds provided as grave goods are evidence for agricultural life, as is the sided hatchet. Therefore, Mesolithic and Neolithic life styles and their corresponding tools cannot be neatly separated, as is often assumed in archaeology. In this era people already permanently settled, and consequently, matters relating to fertility, crop diseases, safety and protection seem to have received much attention resulting in religious beliefs and practices that were directed probably towards the ancestors. The megalithic constructions are likely to have been related to ancestor worship.

Around the first centuries AD, or by the time Hinduism was brought in, the life at Pacung was becoming developed and more complex. This can be shown by the discovery of a refined metal-producing tool, that is, a mould used for melting metals, especially bronze. The metal artefacts found were bronze bracelets, bronze kettledrums, and bronze axes which were used as daily tools, ceremonial equipment and grave goods. The tradition of secondary burial in containers such as the jar found at Pacung site has also been known from other sites in Indonesia connected to the Bronze-Iron Age.

\section{References}

Ardika, I Wayan et al.

1987 Bronze Artifacts and the Rise of Complex Society in Bali. M.A. Thesis. Canberra: Australian National University.

1989 Laporan Ekskavasi Arkeologi di Situs Sembiran dan Pacung, Kecamatan Tejakula, Buleleng. Denpasar: Fakultasa Sastra, Universitas Udayana.

1991 Archaeological Research in Northeastern Bali. A Thesis Submitted for the Degree of Doctor of Philosophy at the Australian National University. Canberra: Australian National University.

1996 Ekskavasi Arkeologi di Situs Sembiran. Kecamatan Tejakula, Kabupaten Buleleng.

Ardika, I Wayan and I Made Sutaba (eds.)

1996 Dinamika Kebudayaan Bali. Denpasar: Upada Sastra. 
Grootes, P.M.

2004 Datierungsergebnisse der Knochenproben 25125, 25126. Unpublished Report. Leibniz Labor für Altersbestimmung und Isotopenforschung. ChristianAlbrechts-Universität Kiel..

Goris, R.

1954 Prasasti Bali. Lembaga Bahasa dan Budaya. Fakultas Sastra dan Filsafat, Universitas Indonesia. Bandung: Masa Baru.

Heekeren, H. R. van

1955 (1992) New Investigation on the Lower Paleolithic Culture in Java. Berita Dinas Purbakala, Bulletin of the Archaeological Service of the Republic of Indonesia, Vol. 1; Repr. Djatop. 660/ BC.-1.000 bk/ 55; Jakarta.

1958 The Bronze-Iron Age of Indonesia. Verhandelingen van het Koninklijk Instituut voor Taal-, Land- en Volkenkunde, Vol. XXII. 's-Gravenhage: Martinus Nijhoff.

Movius, Jr. H.L.

1949 The Lower Palaeolithic Cultures of Southern and Eastern Asia. Transactions of the American Philosophical Society 38, 4, (new series); pp. 329-340. Philadelphia: The American Philosophical Society.

Soegondo, Santoso

2002 Gambaran tentang Gerabah Situs Sembiran: Pembahasan tentang Disertasi I Wayan Ardika, Kumpulan Makalah Pertemuan Ilmiah Arkeologi VIII. Jakarta: Ikatan Ahli Arkeologi Indonesia.

Soejono, R.P.

1962 Primary Notes on New Finds of Lower Paleolithic Implements from Indonesia, Asian Perspectives V: 217- 233.

1976 Tinjauan tentang Pengkerangkaan Prasejarah Indonesia. Aspek-Aspek Arkeologi Indonesia, Vol. 5. Jakarta: Departement Pendidikan dan Kebudayaan (PPKPN).

1982 On the Megalithic in Indonesia. Megalithic Cultures in Indonesia, Monographs Vol. 2. Singapore: Hanyang University Press.

Soejono, R.P. et al.

1984 Jaman Prasejarah di Indonesia. Sejarah Nasional Indonesia, Vol. I. Jakarta: Departemen Pendidikan dan Kebudayaan.

Suantika, I Wayan

1991 Ekskavasi Situs Bangsal Desa Tejakula, Kecamatan Tejakula, Kabupaten Buleleng. Laporan Penelitian Arkeologi. Denpasar: Balai Arkeologi Denpasar.

Suastika, I Made

1990 Diskripsi Alat-Alat Batu. Hasil Penelitian Situs Pacung dan Sekitarnya. Laporan Penelitian Arkeologi. Denpasar: Pusat Penelitian Arkeologi Nasional, Balai Arkeologi.

2000a Analisis Teknologis Alat-Alat Paleolitik Sembiran. Bulletin Prasejarah/ Bulletin of Prehistory, Vol. I. Jakarta: Asosiasi Prehistori Indonesia.

2000b The Paleolithic Tool From Bali. Forum Arkeologi, Vol. 1:46-58. Denpasar: Balai Arkeologi Denpasar. 
2005 Menapak Kehidupan Gua di Nusa Penida, Bali. Berita Penelitian Arkeologi. Denpasar: Badan Pengembangan Sumberdaya Kebudayaan dan Pariwisata, Pusat Penelitian dan Pangembangan Arkeologi Nasional.

Sudiono and Arfian

1995 Penelitian Arkeometri di Situs Sembiran, Kecamatan Tejakula, Kabupaten Buleleng, Propinsi Bali. Laporan Penelitian Arkeologi Bidang Arkeometri. Jakarta: Pusat Penelitian Arkeologi Nasional.

Sukendar, Haris

1993 Arca Menhir di Indonesia. Fungsinya dalam Peribadatan. Jakarta: Universitas Indonesia.

Sutaba, I Made

1976 Megalithic Traditions in Sembiran North Bali, Aspek-Aspek Arkeologi Indonesia, Vol. 4. Jakarta: Pusat Penelitian Arkeologi Nasional.

Tim Jurusan Arkeologi

2003 Hasil-Hasil Penelitian Situs Pacung Kecamatan Tejakula. Denpasar: Laporan Penelitian Fakultas Sastra Universitas Udayana.

2004 Laporan Penelitian Ekskavasi Arkeologi di Situs Pacung, Kecamatan Tejakula, Buleleng. Denpasar: Fakultas Sastra, Universitas Udayana.

Wheeler, R.E.M., Ghosh, A. and Krishna Deva.

1946 Arikamedu: an Indo-Roman Trading Station on the East Coast of India. Ancient India 2: 17-124.

Widia, I Wayan

1981 Temuan Nekara Perunggu Tejakula. Saraswati 17. Denpasar: Muesum Bali.

Widianto, Harry et al.

1998 Penelitian Situs Sangiran: Eksistensi Artefak pada Awal Kala Plestosen Tengah dan Stratigrafi Endapan Teras di Atas Seri Kabuh dan Seri Notopuro. Berita Penelitian Purbakala Daerah Istimewa Yogyakarta, Balai Arkeologi. Yogyakarta: Pusat Penelitian Arkeologi Nasional, Departemen Pendidikan dan Kebudayaan. 
Table 3a: Dating Results for KIA25125: 2004; S 6, Excavation Site Pacung

KIA25125 (PCN IV. S 6/II, Right Femur); Radiocarbon Age

2090BP \pm 37 ; Calibrated Age (2 Sigma): cat BC (196-4)

\begin{tabular}{|c|c|c|c|}
\hline Fraction & $\mathrm{PMC}_{(\text {corrected) }}{ }^{\dagger}$ & Radiocarbon-Age & $\delta 13 \mathrm{C}(\% 0)^{\ddagger}$ \\
\hline Bones, Collagen, $2.9 \mathrm{mg} \mathrm{C}$ & $77.09 \pm 0.26$ & $2090 \pm 25 \mathrm{BP}$ & $-17.12 \pm 0.07$ \\
\hline Radiocarbon Age: & \multicolumn{3}{|l|}{$2090 \pm 27$} \\
\hline Calibrated Age: & \multicolumn{3}{|l|}{4} \\
\hline \multirow{3}{*}{$\begin{array}{l}\text { One Sigma Range: cal BC } \\
\text { (Probability 68,3\%) }\end{array}$} & \multicolumn{3}{|c|}{ (Probability $20.5 \%$ ) } \\
\hline & $119-88$ & \multirow{2}{*}{\multicolumn{2}{|c|}{$\begin{array}{l}\text { (Probability } 26.6 \% \text { ) } \\
\text { (Probabilitv } 21.2 \% \text { ) }\end{array}$}} \\
\hline & 80-54 (Probab & & \\
\hline \multirow{3}{*}{$\begin{array}{l}\text { Two Sigma Range: cal BC } \\
\text { (Probability 95,4\%) }\end{array}$} & 196-192 (Probab & \multicolumn{2}{|c|}{ (Probability $1.0 \%$ ) } \\
\hline & $175-42$ & \multicolumn{2}{|c|}{ (Probability $93.5 \%$ ) } \\
\hline & (Probab & \multicolumn{2}{|c|}{ (Probability $1.0 \%$ ) } \\
\hline
\end{tabular}

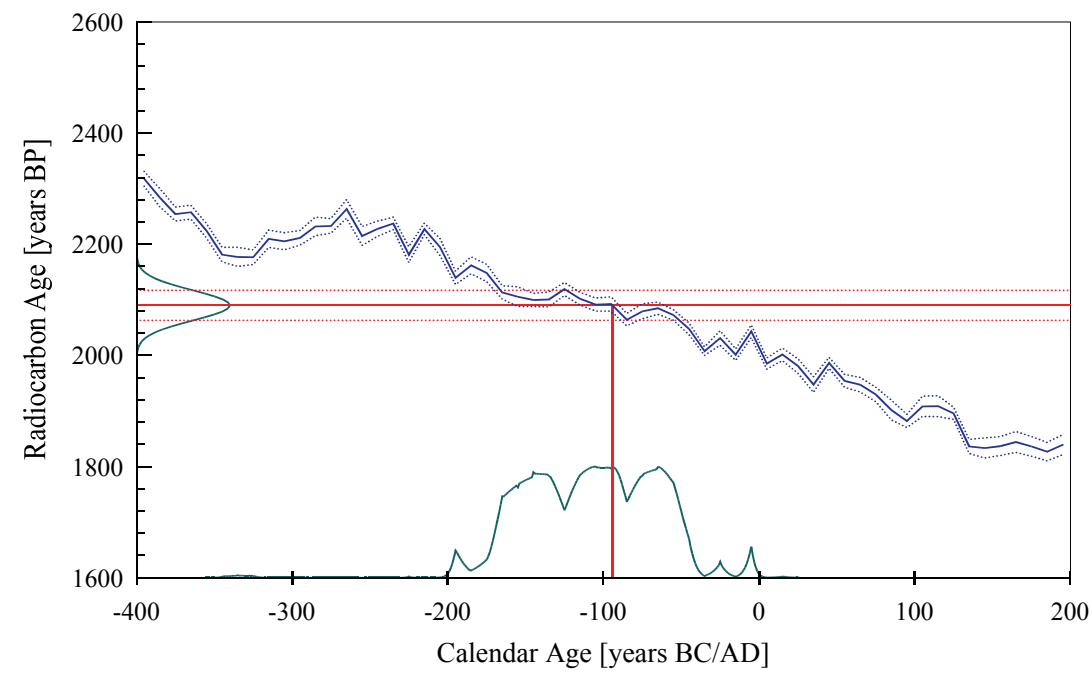

Calibrated age specified by:

Stuiver et al.

1998 „CALIB rev 4.3 (dataset 2)“, Radiocarbon 40, 1041 - 1083.

† "Corrected PMC" indicates the percent of modern (1950) carbon corrected for fractionation using the ${ }^{13} \mathrm{C}$ measurement. The indication " $>$ AD $1954 *$ " denotes the influence of bomb ${ }^{14} \mathrm{C}$.

$\ddagger$ Please note that the $\delta{ }^{13} \mathrm{C}$ includes the fractionation occurring in the sample preparation as well as in the AMS measurement and therefore cannot be compared to a mass-spectrometer measurement. 
Table 3b: Dating Results for KIA25125: 2004; S 6, Excavation Site Pacung

KIA25126 (CN IV. S 6/III, Left Humerus); Radiocarbon Age

2103BP \pm 37 ; Calibrated Age (2 Sigma): cal BC (198-47)

\begin{tabular}{|c|c|c|c|c|}
\hline \multicolumn{2}{|l|}{ Fraction } & $\mathrm{PMC}$ (revised) $^{\dagger}$ & Radiocarbon -Age & $\delta^{13} \mathrm{C}(\%)^{\ddagger}$ \\
\hline \multicolumn{2}{|l|}{ Bones, Collagen, $3.8 \mathrm{mg} \mathrm{C}$} & $76.97 \pm 0.26$ & $2105 \pm 25 \mathrm{BP}$ & $-17.40 \pm 0.32$ \\
\hline $\begin{array}{l}\text { Radiocarbon Age: } \\
\text { Calibrated Age: } \\
\text { One Sigma Range: } \\
\text { (Probability 68, } 3 \% \text { ) } \\
\text { Two Sigma Range: } \\
\text { (Probability 95, 4\%) }\end{array}$ & $\begin{array}{l}\text { BP } \\
\text { cal BC } \\
\text { cal BC } \\
\text { cal BC }\end{array}$ & $\begin{array}{ll}2103 \pm 27 & \\
151,134, & 116 \\
168-92 & \text { (Probal } \\
69-63 & \text { (Probal } \\
198-188 & \text { (Probal } \\
181-47 & \text { (Probal }\end{array}$ & $\begin{array}{l}\text { ty } 63.5 \%) \\
\text { ty } 4.8 \%) \\
\text { ty } 2.9 \%) \\
\text { ty } 92.5 \%)\end{array}$ & \\
\hline
\end{tabular}

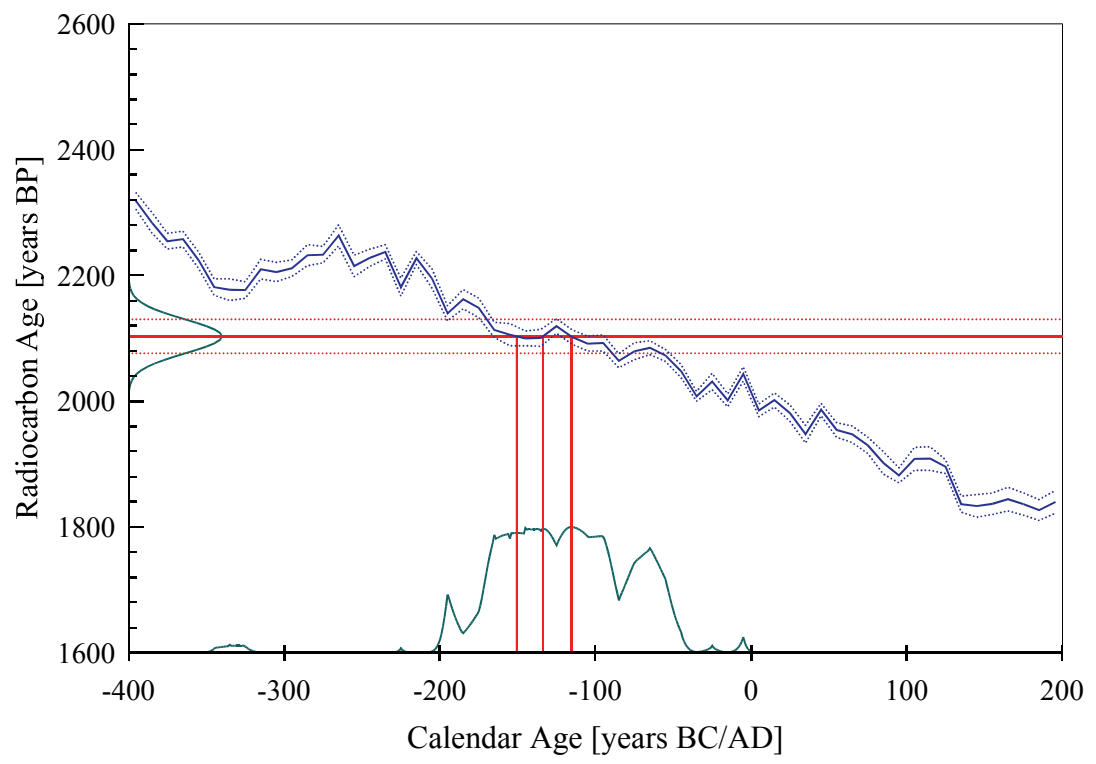

Calibrated age specified by:

Stuiver et al.

1998 „CALIB rev 4.3 (dataset 2)“, Radiocarbon 40, 1041 - 1083.

t "Corrected PMC" indicates the percent of modern (1950) carbon corrected for fractionation using the ${ }^{13} \mathrm{C}$ measurement. The indication "> AD 1954*" denotes the influence of bomb ${ }^{14} \mathrm{C}$.

$\ddagger$ Please note that the $\delta{ }^{13} \mathrm{C}$ includes the fractionation occurring in the sample preparation as well as in the AMS measurement and therefore cannot be compared to a mass-spectrometer measurement. 



\title{
The Burial System at Pacung
}

\author{
Marini Drawatik
}

\section{Introduction}

A burial system is a set of elements which are regularly related to one another in such a way that a totality, including procedures, methods, ceremonies and everything related to burial, is formed. The activities related to the burial cover the maintenance and preparation of the corpse, the making of offerings, the ceremonies necessary and the implementation of the burial. All these activities need accurate management and a detailed listing of all the tasks to be performed because they involve most or all of the community members (Binford 1972:232-400; Soejono 1977:9-10). In a burial system there are some particular rules related to the position of the corpse, the container used, the accompanying provisions for the dead person and everything related to the ceremony (Wirastri 1990:5-6).

A cemetery is part of an activity area since burials are repeatedly carried out there and since it forms a structure of activities of a particular social group belonging to a definite settlement (Binford 1972:146; Aziz 1987:158-160). The choice of a settlement area is, at least in prehistoric times, very much related to the adaptation of people to their environment, the availability of water and the other facilities needed such as means of transportation as well as natural resources that can supply foodstuffs (Tim Jurusan Arkeologi 1998:8). The reason why people in the prehistoric era chose the region of Pacung can be found in the favourable environmental conditions for human survival. It is located at the estuaries of several 
rivers close to the coast and forest. The location was able to supply an abundance of fresh water, all maritime produce (fish, salt etc.) and other natural resources (see Suastika this volume).

The earlier researches conducted at the Pacung site in 1987 and 1989 found fragments of pottery both local and made in India and China, animal bones and some compositions of stones indicating the construction foundations built in the past. This reveals that the Pacung site was considered a complex settlement (see Ardika and Suastika this volume). Related to the burial, I Wayan Ardika, in his dissertation, mentioned two findings of human skeletons in trench SBN VII (excavation trench Sembiran VII). The first skeleton was found flexed in an east-west position with face southwards. Its arms and legs appeared to be folded. Some beads, possibly functioning as grave goods (Ardika 1991:37), were associated with the first skeleton. The second skeleton was in a flexed position as well but only some remains and leg bones were found. In the following years several skeletons with different positions, directions and orientations were found.

\section{The Prehistoric Burial Patterns}

According to R.P. Soejono, the prehistoric burials consisted of a number of different patterns. The main patterns of burials are as follows:

1. The primary burial can be classified into the burial without any container (Soejono 1977:92), and the burial with permanent container such as a jar, a stone room, dolmen or sarcophagus in which the corpse was placed (Soejono 1969:2).

2. In the secondary burial all or parts of the bones were buried with or without containers such as jars or sarcophagi. The bones were not anatomically placed, but looked mixed or incomplete; however they showed a particular pattern (Soejono 1969, 1977).

3. A mixed burial system consisted of both primary and secondary burials.

4. In an open burial system the corpse was exposed on the ground at a particular area such as at coral cliffs, cave walls, big stones, big trees and so on (Sudiono 1985:66). The open burial was usually followed by a selective one in which half the bones were buried under the ground or were put in a particular container as can be seen at Toala (South Sulawesi) and Trunyan (Central Bali).

Based on the prehistoric patterns of burial generally mentioned above, the prehistoric patterns of burial at the Pacung site can be described as follows:

\section{Burial Container}

In trench PCN IV (excavation trench Pacung IV) a closed jar containing human remains was found; thus evidence of a secondary burial $(\mathrm{S} \mathrm{X})$ is present. The skull was directed towards the sea. Adjacent to the nearby Ponjok Batu temple, a sarco- 
phagus serving as a burial container (primary burial) was also found. The sarcophagus was made of sandstone and a small amount of andesit stone. Those who were primarily and secondarily buried with sarcophagi and jars as containers probably had high social status and important positions (Mahaviranata 2002:23).

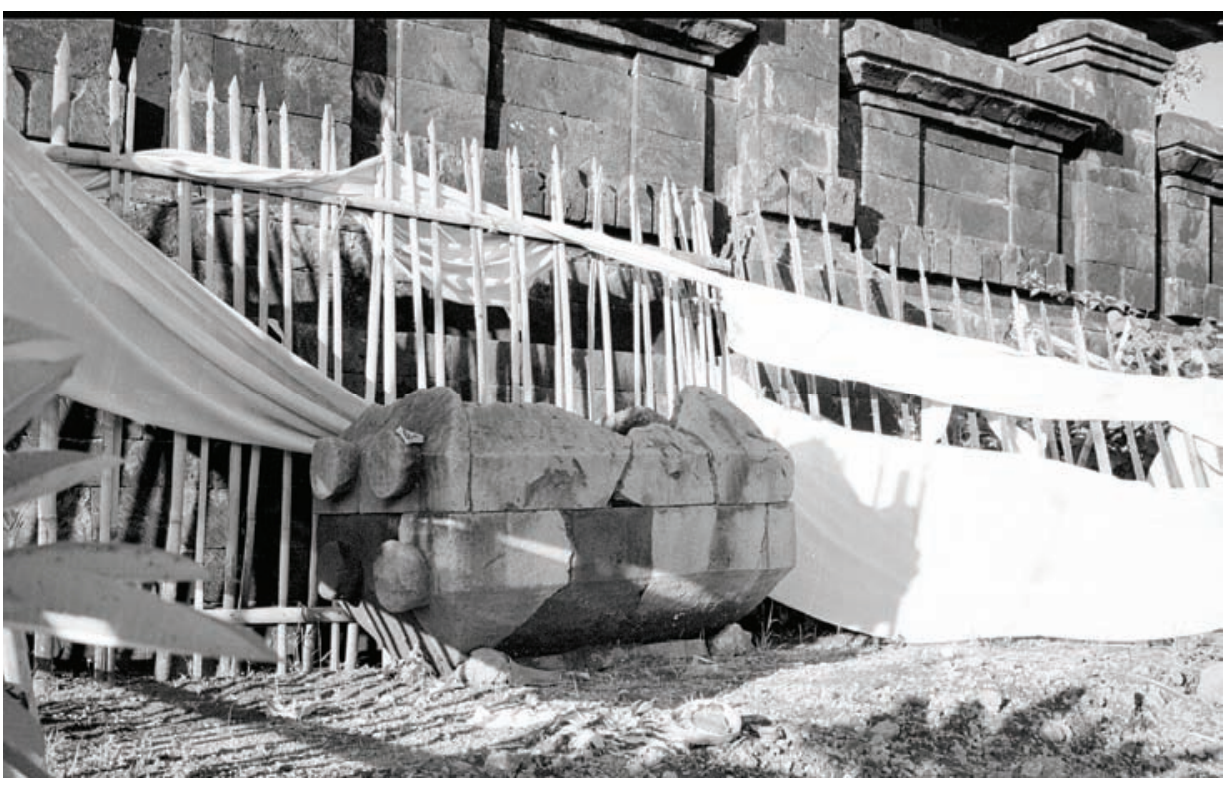

Photo 1: Sarcophagus found at the Ponjok Batu Temple. Photo: Brigitta HauserSchäublin 1999.

\section{The Position of the Bodies}

The human skeletons found from the excavation at the Pacung site until 2004 totalled 10 derived from PCN III and PCN IV (see Table 1; Ardika this volume). Half the skeletons were found complete with the bones still anatomically related and the other half were found in an incomplete state. Incisor, canis, molar and premolar, some fragments of backbones (vertebra), and fragments of ribcages and of skulls were also found.

Skeleton I (S I) was found in trench PCN III at spit 35 and $360 \mathrm{~cm}$ under the earth's surface. This skeleton was put on a clay layer mixed with rough sand blackish brown in colour. Not all the skeleton, but merely some fragments mixed and caught under natural stones were visible. The fragments were not anatomically related. The fragments in S I were not regularly piled and no skull was found; the orientation of the corpse could therefore not be identified.

Skeleton II (S II) belonged to an adult individual found at $385 \mathrm{~cm}$ under the earth's surface and at a clay layer mixed with sand. The arms were flexed (flexed position) with the lower arms folded up under the shoulders. The body was found 
complete with the bones in an anatomically correct position, except for the feet, which may perhaps be located in the wall of the excavation trench. The corpse had been buried straightaway without any permanent containers.

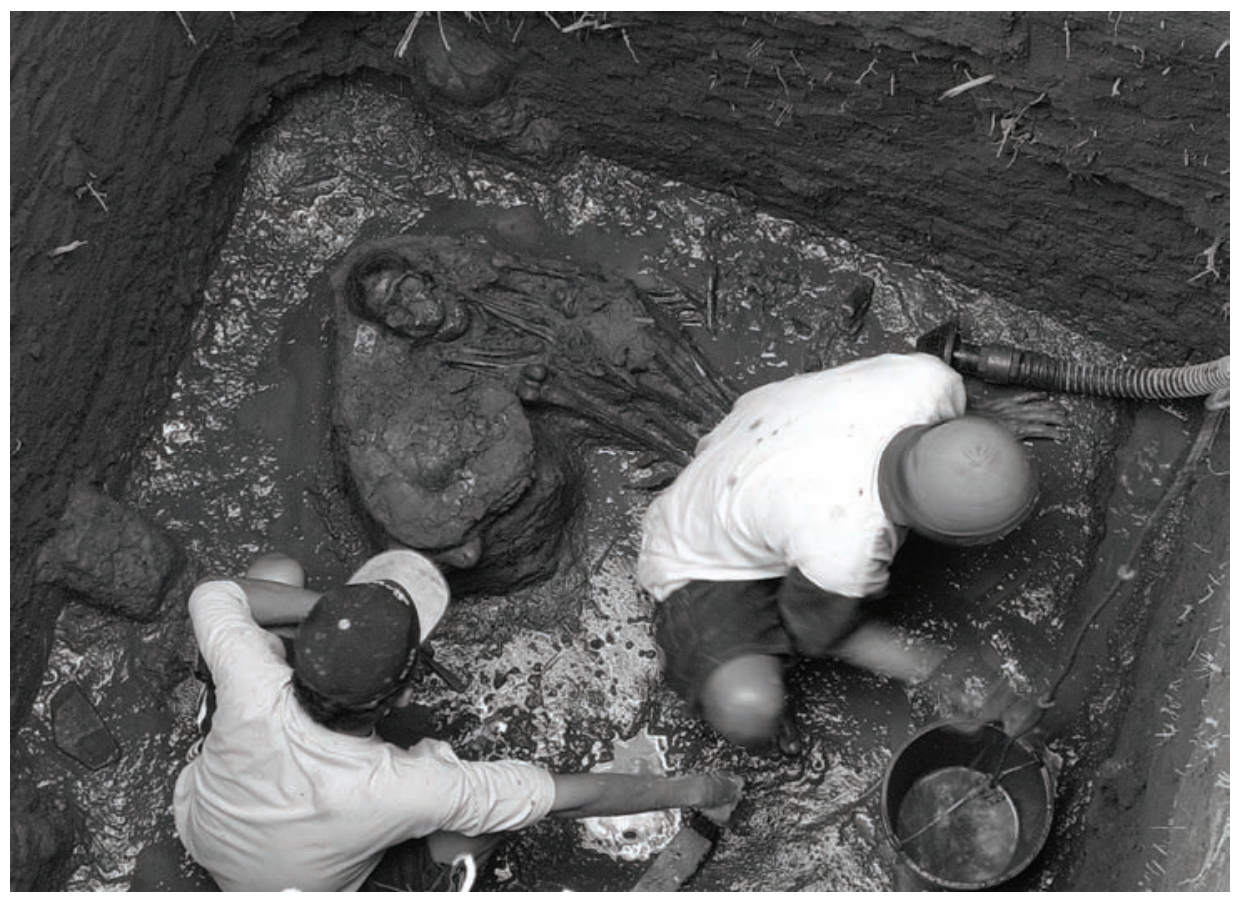

Photo 2: The excavation site Pacung IV with a skeleton in a flexed position and a jar containing a skull adjacent to the skeleton. These finds were located $400 \mathrm{~cm}$ below the ground surface and the sea level. The bottom of the trench had to be continuously drained.

Photo: Brigitta Hauser-Schäublin 2004.

As the careful analyses showed, the bones from what was first identified as Skeleton III (S III) and Skeleton IV (S IV) probably belong to one individual because they had the same colour and were found close to each other. They were located at $390 \mathrm{~cm}$ under the earth's surface. S III consisted only of a skull which was found undamaged. S IV included bones of legs that probably belonged to the same skeleton as the skull. These remains suggest an uncovered secondary burial. After the corpse had decayed, some bones considered important had been selected for burial. Parallel to the skull (S III), fragments of local pottery red in colour and forming part of burial provisions were found.

Skeleton V (S V) belonged to an adult individual which was located in PCN IV. S V consisted only of a damaged skull. The body of S V apparently became 
separated from the skull. It may perhaps be located in the wall of the excavation trench. To the north of S $\mathrm{V}$ a damaged clay pan was found.

Skeleton VI (S VI) was found in PCN IV lying in a flexed position. The skull appeared to be undamaged, the arms were folded up under the shoulders and the feet were in a squatting position. The whole body was slanted to the right. On the right side of S VI, parallel to its head a closed jar was found. The burial of a flexed body in the prehistoric era may have been based on the belief that a corpse should be in a similar position as a baby in his mother's womb. This possibly is an indicator for the belief in rebirth (Mahaaviranata 2002:22).

Skeleton VII (S VII) was located in trench PCN IV at a depth of $400 \mathrm{~cm}$ under the earth's surface. Only arm-bones could be discovered. The other findings were in the form of six bronze bracelets (two of them were found worn on the wrist and four off the wrist but still close to the arms).

Skeleton VIII (S VIII) was found in PCN IV at $425 \mathrm{~cm}$ under the earth's surface. Most the bones were not anatomically related and were in bad condition. Nevertheless, the skeleton gives evidence of a primary burial without permanent container.

Skeleton IX (S IX) was located in trench PCN IV at spit 43 which was $230 \mathrm{~cm}$ below the surface. While half the bones were in bad condition, the other half appeared to be undamaged and anatomically related. Some fragments of a skull were found to the north and the feet were found to the south. There were three clay pans found to the left, parallel to the head. A comparative point of view of S VI and S IX leads to the conclusion that this site was a multiple burial site. First, S IX was buried followed by S VI but at the same location. In the process of the burial, S IX was dug up, either intentionally or unintentionally, so that there was enough space for the relocation of S VI. This could be the reason for the damage to S IX. Similar circumstances can be found at several prehistoric burial sites such as at the Gilimanuk Site and Gunung Wingko Site, South Central Java (Simanjuntak 1979:61).

Skeleton X (S X) was found inside a jar, which at first was assumed to be grave good for S VI. After the jar was lifted, a skull was discovered; S X indicates a secondary burial with a permanent container

A careful examination revealed an anatomical difference between S I and S X with regard to the teeth and other parts of the body. One skeleton displayed apparent traces of tooth-filing. This was shown by a loose finding in the form of fragments of incisors in trench PCN IV. On the fragments of teeth some filing marks were seen that were probably applied during a life cycle ceremony, the transition from childhood to adulthood (Simanjuntak 1979:66-67). 
Table 1: Description of Findings of Human Remains

\begin{tabular}{|c|c|c|c|c|c|c|c|c|c|c|c|c|c|c|c|c|c|c|c|}
\hline \multirow[t]{2}{*}{ No } & \multirow[t]{2}{*}{$\begin{array}{l}\text { Skele- } \\
\text { ton }\end{array}$} & \multicolumn{2}{|c|}{$\begin{array}{l}\text { Posi- } \\
\text { tion } \\
\text { of } \\
\text { the } \\
\text { body }\end{array}$} & \multicolumn{2}{|c|}{$\begin{array}{l}\text { Posi- } \\
\text { tion of } \\
\text { the legs }\end{array}$} & \multicolumn{2}{|c|}{$\begin{array}{l}\text { Posi- } \\
\text { tion of } \\
\text { the } \\
\text { arms }\end{array}$} & \multicolumn{6}{|c|}{ Condition of skeleton } & \multicolumn{6}{|c|}{ Types of burial } \\
\hline & & $\mathrm{a}$ & $b$ & C & $d$ & $\mathrm{e}$ & $f$ & 1 & 2 & 3 & 4 & 5 & 6 & $A$ & $B$ & C & $\mathrm{D}$ & $E$ & $\mathrm{~F}$ \\
\hline 01 & S.I & & $X$ & & $X$ & & & & & & & & $\mathrm{X}$ & & & & & & $\mathrm{X}$ \\
\hline 02 & S. II & $\mathrm{X}$ & & & $X$ & $X$ & & & $X$ & & & & & $X$ & & & & $X$ & \\
\hline 03 & S. III & & $X$ & & $X$ & & $\mathrm{X}$ & $X$ & & & & & & & $X$ & & & & \\
\hline 04 & S. IV & & $x$ & $X$ & & & $x$ & & & $x$ & & & & & $B$ & & & & \\
\hline 05 & S. V & & $X$ & & & & $\mathrm{X}$ & $X$ & & & & & & & & & & & $\mathrm{X}$ \\
\hline 06 & S. VI & $\mathrm{X}$ & & $X$ & & $X$ & & & $\mathrm{X}$ & & & & & $x$ & & $X$ & $\mathrm{D}$ & & \\
\hline 07 & S. VII & & $x$ & & $X$ & & $x$ & & & & $\mathrm{X}$ & & & $A$ & & & & & \\
\hline 08 & S. VIII & & $X$ & & $X$ & & $x$ & & & & & & $\mathrm{X}$ & & & & & & $\mathrm{X}$ \\
\hline 09 & S. IX & & $X$ & & $X$ & & $x$ & & & $\mathrm{X}$ & & $X$ & & $x$ & & & $X$ & & \\
\hline 10 & R. X & & $X$ & & $X$ & & & $X$ & & & & & & & & $X$ & & & \\
\hline \multicolumn{4}{|c|}{$\begin{array}{l}a=\text { stretched out } \\
b=\text { unknown } \\
c=\text { legs flexed } \\
d=\text { unknown } \\
\text { e }=\text { arms flexed } \\
\mathrm{f}=\text { not identified }\end{array}$} & \multicolumn{8}{|c|}{$\begin{array}{l}1=\text { skull } \\
2=\text { bones still in original } \\
\quad \text { anatomical position } \\
3=\text { leg bones } \\
4=\text { arm bones } \\
5=\text { damaged bones } \\
6=\text { fragments, mixed }\end{array}$} & \multicolumn{8}{|c|}{$\begin{array}{l}\mathrm{A}=\text { primary burial with- } \\
\text { out permanent con- } \\
\text { tainer } \\
\mathrm{B}=\text { secondary burial } \\
\mathrm{C}=\text { mixed burial } \\
\mathrm{D}=\text { double burial } \\
\mathrm{E}=\text { single burial } \\
\mathrm{F}=\text { not identified }\end{array}$} \\
\hline
\end{tabular}

\section{Orientation of the Skeletons}

The dominant direction of the skeletons found at the Pacung site was north-south with the head facing southward. "South" points at the mountains or hills where, according to today's understanding, the ancestors' souls are supposed to reside. Such a direction was found in S II and S VI. The skeletons were positioned slightly aslant to the left with the heads facing the south-west. The fact that the faces were slightly aslant was possibly caused by the pressure of the ground around the head.

Contrary to the position of S II and S VI, the heads of S III and S IV, which were supposed to be the secondary burial, faced north-east, the direction to the sea. The belief that the sea is the residence of the ancestors' souls is often found in the Indonesian ethnic groups residing in the coastal regions.

The skeleton S V laid south-west with the face towards north-east. What might be the reason for this position? Was the deceased a member of a different cultural community with other notions of orientation? Or might it have been an unusual death? 
Another possibility might be that the dead person had come from another region, with the burial pointed toward his place of origin (Soejono 1977:190, 263).

The skull of S X was directed to the north and slightly to the north-east.

Table 2: The Orientation of the Bodies

\begin{tabular}{|c|c|c|c|c|c|}
\hline No & Skeleton & Orientation & $\begin{array}{l}\text { Position of the } \\
\text { Head }\end{array}$ & $\begin{array}{l}\text { Direction of } \\
\text { the Head }\end{array}$ & Description \\
\hline 01 & SI & Unidentified & Unidentified & Unidentified & $\begin{array}{l}\text { Bone fragments } \\
\text { which were mixed } \\
\text { and pressed by } \\
\text { some stones }\end{array}$ \\
\hline 02 & S II & North-south & South & $\begin{array}{l}\text { Looking to the } \\
\text { right }\end{array}$ & $\begin{array}{l}\text { The feet may } \\
\text { perhaps be lo- } \\
\text { cated in the wall } \\
\text { of the excavation } \\
\text { trench (unidenti- } \\
\text { fied) }\end{array}$ \\
\hline 03 & S III & $\begin{array}{l}\text { North-east/ } \\
\text { North-west }\end{array}$ & Northwest & $\begin{array}{l}\text { Facing north- } \\
\text { east }\end{array}$ & Only a skull \\
\hline 04 & S IV & Unidentified & Unidentified & Unidentified & $\begin{array}{l}\text { Only foot bones of } \\
\text { S III }\end{array}$ \\
\hline 05 & S V & North-west & Unidentified & $\begin{array}{l}\text { Looking to the } \\
\text { left }\end{array}$ & $\begin{array}{l}\text { A damaged skull } \\
\text { propped against } \\
\text { the wall }\end{array}$ \\
\hline 06 & S VI & North-south & South & $\begin{array}{l}\text { Straight to the } \\
\text { front }\end{array}$ & $\begin{array}{l}\text { Body slanted to } \\
\text { the right, probably } \\
\text { multiple and } \\
\text { mixed burials }\end{array}$ \\
\hline 07 & S VII & Unidentified & Unidentified & Unidentified & $\begin{array}{l}\text { Arm bones point- } \\
\text { ing north-south } \\
\text { and bronze brace- } \\
\text { lets as burial } \\
\text { provision }\end{array}$ \\
\hline 08 & S VIII & $\begin{array}{l}\text { North-east/ } \\
\text { North-west }\end{array}$ & North-west & Unidentified & $\begin{array}{l}\text { Skeleton found } \\
\text { intact }\end{array}$ \\
\hline 09 & S IX & North-south & South & Unidentified & Multiple burial \\
\hline 10 & $S X$ & - & - & $\begin{array}{l}\text { Facing the } \\
\text { sea }\end{array}$ & $\begin{array}{l}\text { Secondary burial } \\
\text { with container }\end{array}$ \\
\hline
\end{tabular}

\section{Grave Goods}

The excavations at Pacung showed that all skeletons were accompanied by a variety of gifts. The objects often found in the primary as well as in the secondary burial consisted of ritual tools, ornaments, weapons, tools, symbols of wealth and remains of domestic animals. 
The results of the excavation and analysis showed that at Pacung the grave goods of S II, S VI and S VIII were in the form of loose findings; these were beads of various colours, forms and materials, and pottery sherds of different forms such as pans and jars, both of local and Indian origin. Skeletons S III and S IV had clay pans on the right side parallel to the legs. S V had some fragments of a small broken clay pan on the left side of the skeleton. In S IX one clay pan of medium size was found on the left side of the skeleton parallel to the head.

The most conspicuous gifts were bronze bracelets, some of which were found worn and others loose from the arm bone in S VII.

The form and richness of the burial provisions often depended on the status of the dead person and the economic capacity of their relatives conducting the burial ceremony.

\section{The Relation between the Current and the Prehistoric Burial System}

Archaeological and historical evidence (since the mid $19^{\text {th }}$ century) as well as oral history suggest a continuous settlement in the Pacung-Julah-Sembiran region for hundreds or perhaps even thousands of years. Can we assume continuity in some aspects of culture?

An ethnographic comparison with burial practices in today's Pacung may reveal similarities and differences with the prehistoric practices at the same site. An ethnographic investigation into the burial practices therefore formed part of the project.

Burial in Hindu-Balinese culture is a complex activity. It is a system of how to treat a dead person, the corpse and its burial and the ceremonies carried out after the burial procession in order to liberate and purify the soul (Suastika 2002: 1).

The burial ceremony at Pacung consists of three stages:

\section{Treatment of the Corpse}

Today's Pacung community believes that death is a journey to the embang, the eternal world where the souls of those who are dead reside. Birth and death are already determined by Sang Hyang Embang, the Creator (Suastika 2002:2). The holy place belonging to the souls of the ancestors is called pemerajan or sanggah, household temple. This symbolizes the mountain where the souls of the ancestors reside after a purification ceremony has been carried out; the ancestors' souls are then living close to their families and the community. The treatment of the corpse is intimately linked to the belief in a life hereafter.

Before the corpse is brought to the burial ground, the relatives and local community members bath it completely. Then, it is fully dressed and ornamented. Some beauty powder is also polished on it before it is wrapped with white cloth 
and a mat made of palm leaves. After that, the relatives and community members present food (sagi) and water to the deceased. After the food-serving stage is finished, they carry the corpse directly to the cemetery. The equipment needed for bathing the corpse is later thrown away at the cemetery.

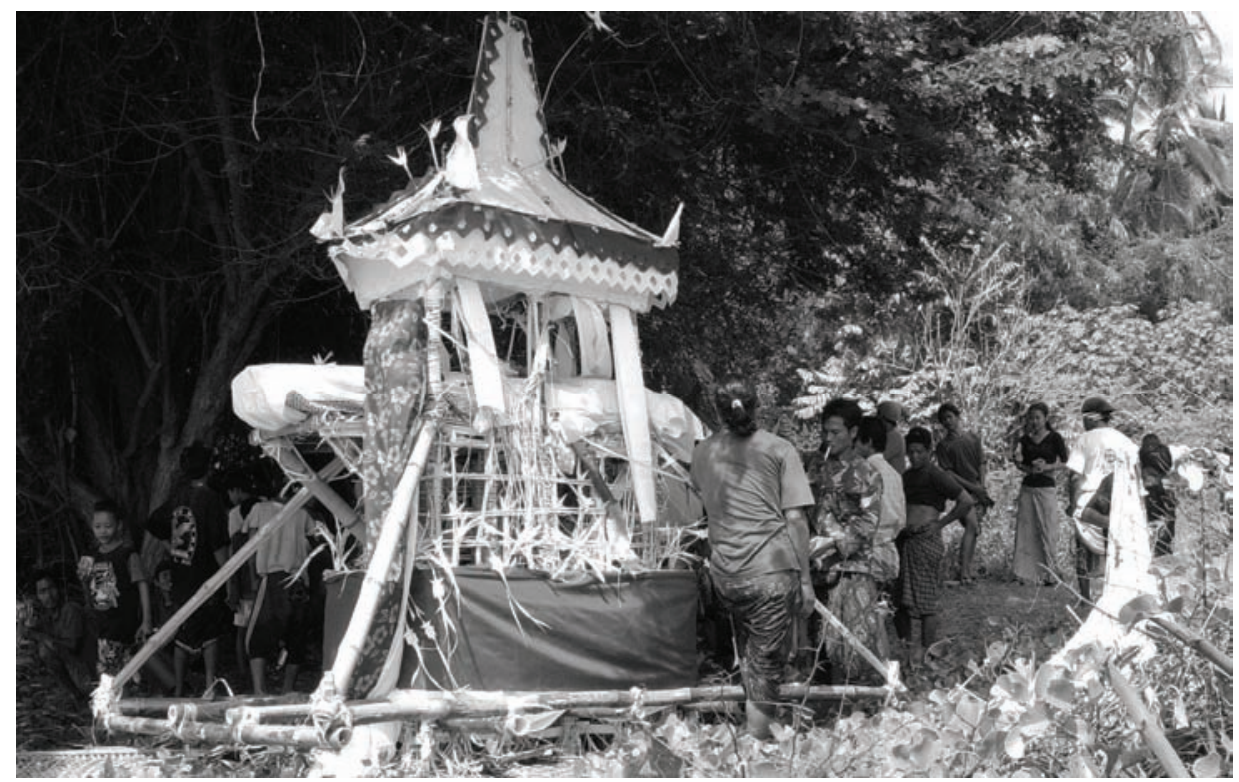

Photo 3: Burial procession Julah. The corpse is wrapped in white cotton cloth and horizontally put on the palanquin. The palanquin is carried by the deceased's relatives to the burial ground.

Photo: Brigitta Hauser-Schäublin 2004.

\section{Burial Procession}

To make the souls reach embang, it is necessary for the relatives and friends of those who are dead to conduct a burial ceremony. A traditional form of burial, according to an informant, was conducted up to 1977, although now some parts have changed. The Pacung villagers carry out a two-fold burial that is, the primary burial (mepegat) followed by the - exclusively symbolic - secondary burial ritual. The primary burial is carried out directly after death, and the second ceremony is conducted 42 days or one month and 7 days after the first one. 


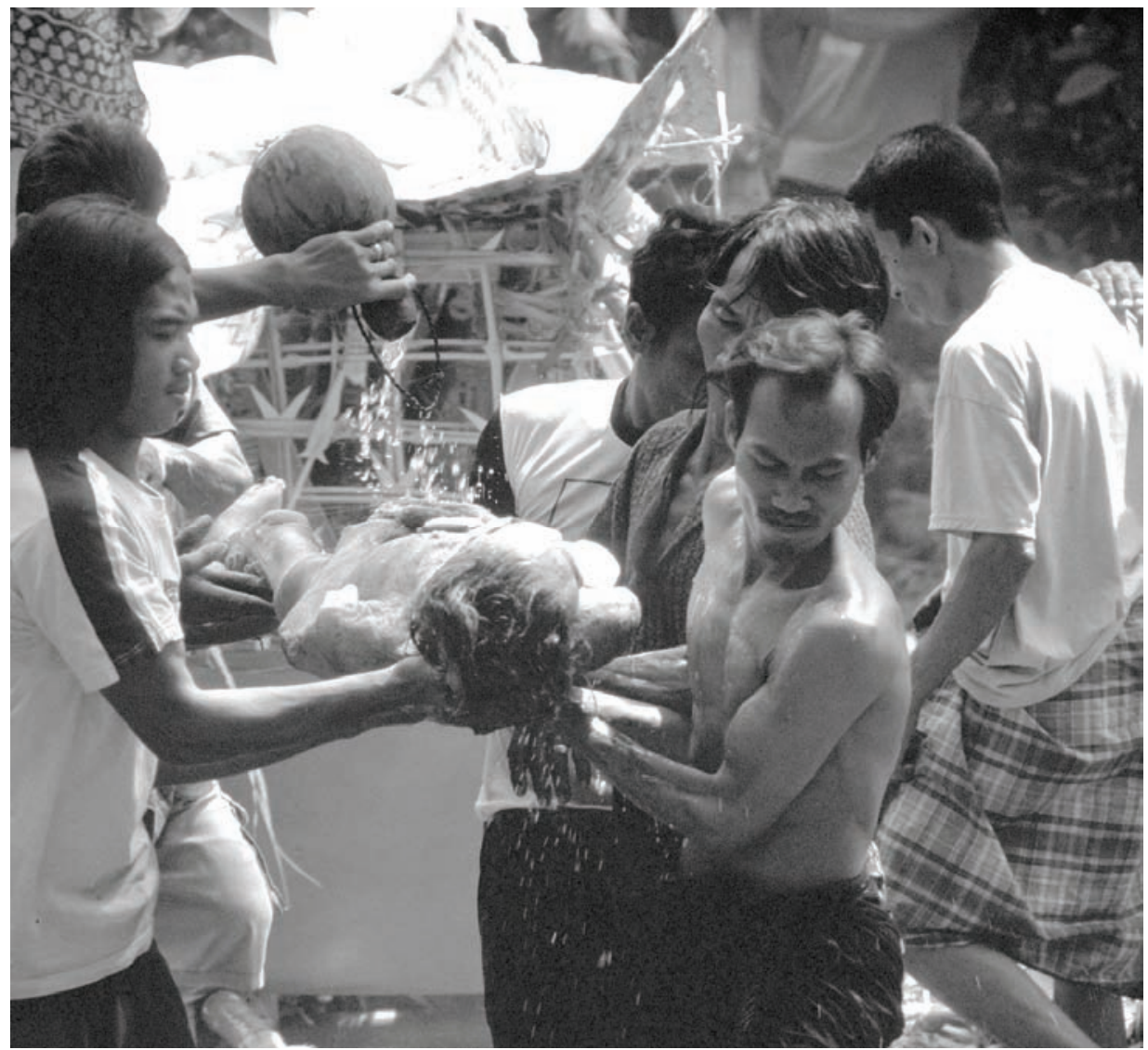

Photo 4: Before the corpse is lowered into the ground it is undressed and washed at the burial place near the sea.

Photo: Enrico Kalb 2004.

At Pacung, if someone dies during the day, the corpse should be buried before the sun sets; if he or she dies during the night, the community should wait for the following day. The ceremony does not have to be carried out on a special day as is done in other communities in Bali. In the event that the relatives live far away and cannot reach their home village within a day, the corpse cannot be kept at home for more than three days.

For the actual burial, a bamboo litter is made, on which the corpse is placed for the mepegat ceremony. This ceremony cuts off the relationship between the dead person and his or her relatives so that they do not object to letting him or her go, having been called by God. This separation is symbolized by white strings of cotton that are cut through by using a small piece of resin that has been set on fire. 


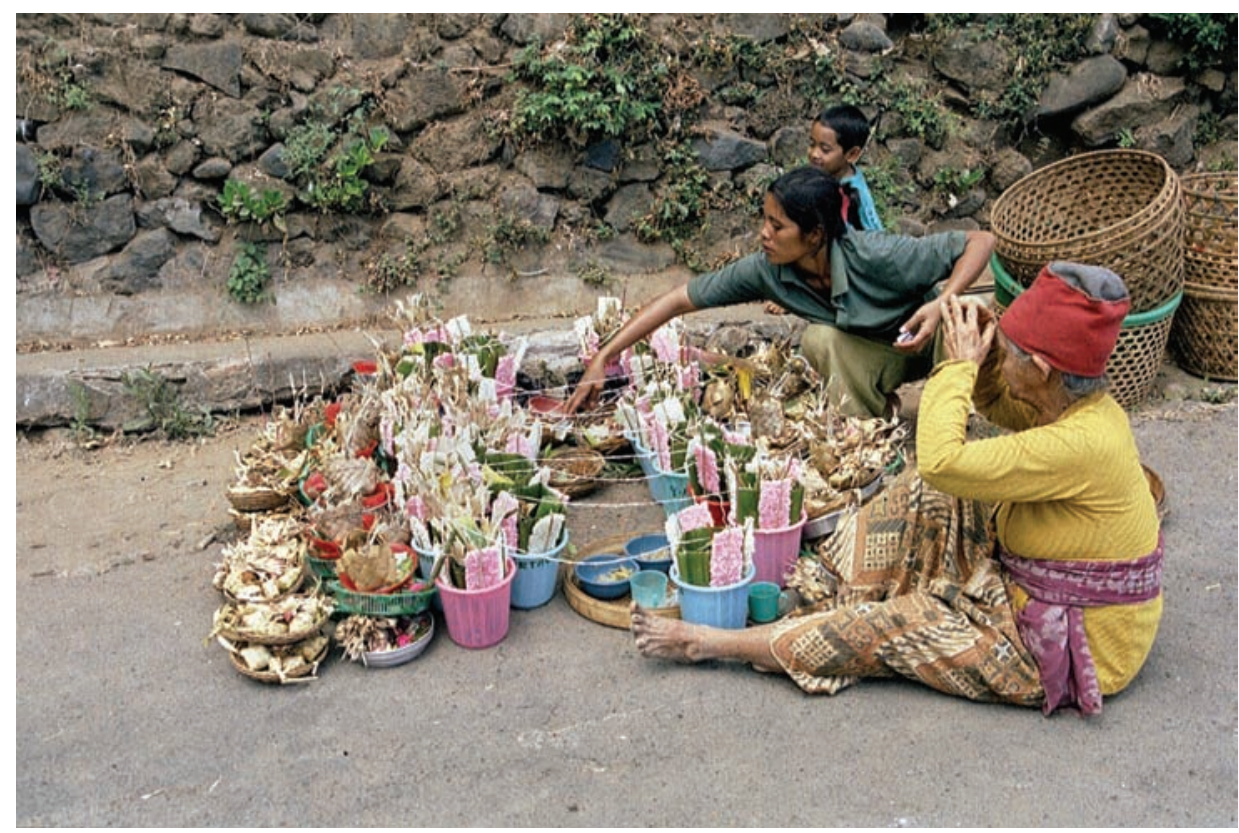

Photo 5: Mepegat Ceremony, the symbolic separation of the deceased from the living by dividing the offerings into two parts (left and right, the latter representing the living) in Sembiran.

Photo: Christian Riemenschneider 2003.

The dead person is provided by the relatives with 11 Chinese coins symbolizing the means of payment for the piece of ground in which the corpse will rest. Sometimes some gold or silver is added. Before the corpse is buried, the 11 Chinese coins and some jambu (Syzygium sp.) leaves are put in the grave and on the corpse. On top of the corpse the relatives put some personal belongings of the deceased as a token of their affection (tresna asik). The corpse is then lowered into the hole and the grave is filled with earth.

The corpse is laid out with the head pointed to the north-east and the feet to the south-west. A male corpse is arranged with the face downward and a female corpse with the face upward. Such positions refer to the belief that male symbolizes the sky and female symbolizes the earth, resulting in fertility or life. However, since 1977 wooden coffins have been used as burial containers at Pacung with the corpse lying stretched out in the same way as described above.

The difference in the orientation of the corpse at Pacung to those in the other regions possibly relates to the Sambu sect, in which death is associated with the north-east, where the God Sambu, who is identical with death, resides.

The grave is marked by stones arranged in the same direction. Finally, the relatives and friends make offerings (sesajen soda) to the deceased. This is intended so that he or she can redeem the mistakes made during his or her lifetime and thus 
give the soul peace (sagi ceremony). The younger relatives pay respect to the deceased (menyumbah) while the older pray (mebhakti).

Before leaving for the cemetery, the dead person's relatives and the community members visit Pura Kahyangan Tiga (the three major village temples), Pura Puseh (Temple of Origin), Pura Desa (Village Temple), Pura Dalem (Death Temple) and finally the family temple to pray.

Eleven days after the burial ceremony they build a permanent grave made of cement to avoid a possible further digging up of the ground for another burial by someone else. In such a case, the corpse would have to be buried together with the old one. If another grave is made, all the ceremonies mentioned above have to be performed again.

\section{The Ceremony of Metuun}

The metuun ceremony is a kind of second burial ritual in which the soul of the deceased is invoked to return; it needs to be purified before returning to embang.

The metuun ceremony is usually performed 42 days after the death if the relatives can afford it. In case they need more time to accumulate wealth for the ceremony, they have to wait for another three or six months, depending on what is decided by the core villagers. Those who are not economically capable are given one year to conduct such a ceremony and the date is set by the village. If they are still unable to perform the ceremony after this year, it is the village's obligation to do so. At the beginning of the ritual, a deity, Bhatara Ratu Gede Dalem, is asked to grant holy water (tirta) so that the deceased (or rather his soul) can be purified. A small manikin (jejeneng) symbolising the deceased is ritually cleansed and then dressed in white at a site dedicated to the dead (merajapati). The soul of the deceased is then called to descend into the jejeneng, which is then carried home and put on the bed of the deceased. There, a purification ritual is carried out. Afterwards, the soul is brought back to the merajapati from where the soul is supposed to return to embang; the jejeneng remains at the merajapati.

\section{Conclusion}

If we compare the prehistoric burial with current practice at Pacung some similarities can be detected, though continuity in populations or culture cannot be assumed. Many fundamental changes have taken place over the past hundreds of years. With regard to the belief system which heavily influences attitudes towards death and life in the after-world, we need to consider the advent of Hinduism and the impact it had on the existing burial system. Nevertheless it is important to state that, traditionally, cremation was not carried out in Pacung. The prehistoric community apparently conducted the primary burial without containers. Nowadays wooden coffins are used, but before 1977 the corpse was merely wrapped in 
mats. However, today the bones are not exhumed after the decomposition of the corpse and put in a special container for a second burial as was done in prehistoric times. Instead, a purification ritual for the soul, metuun, is carried out without touching the corpse again to facilitate the soul's return to embang. Such a ritual leaves no material traces. We know practically nothing about prehistoric life, only the evidence provided by remains.

With regard to the orientation of the corpse we can say that in the prehistoric era the dominant direction was north-south with the head facing southward, while nowadays the orientation of the corpse is north-east, south-west with the head facing north-eastward.

The excavations have shown that the dead were provided with all kinds of goods. This still applies to burials today. If the burial provisions in the prehistoric era were in the form of pottery, beads and metal, those currently used are in the forms of Chinese coins and other things requested by the deceased during his or her lifetime.

\section{References}

Ardika, I Wayan

1991 Archaeological Research in Northeastern Bali. A Thesis Submitted for the Degree of Doctor of Philosophy at the Australian National University. Canberra: Australian National University.

Aziz, Fadila Arifin

1987 Analisis Kubur Situs Plawangan. Proceedings Analisis Hasil Penelitian Arkeologi, Vol. I: 157-177. Jakarta: Pusat Penelitian Arkeologi Nasional: 157-177

Binford, Lewis R.

1972 An Archaeological Perspective. New York: Seminar Press.

Mahaviranata, Purusa

2002 Tingkat Status Social pada Kubur Manikliu, Kintamani, Bali. Pertemuan Ilmiah Arkeologi, Vol. V. Jakarta: Pusat Penelitian Arkeologi Nasional.

Simanjuntak, Harry Truman

1979 Penelitian Desa Pekraman dalam Mewujudkan Jagaditha di Era Globalisasi. Guratan Budaya dalam Perspektif Multikultural. Denpasar: Fakultas Sastra dan Budaya Universitas Udayana.

Soejono, R.P.

1969 On Prehistoric Burial Methods in Indonesia. Bulletin of the Archaeological Institute of the Republic of Indonesia. Jakarta: Lembaga Purbakala dan Peninggalan Nasional.

1977 Sistem-Sistem Penguburan pada Akhir Masa Prasejarah di Bali. Unpublished Dissertation. Jakarta: Universitas Udayana. 
Suastika, I Made

2002 Tata Cara Penguburan di Desa Pacung, Buleleng. Forum Arkeologi. Denpasar: Balai Arkeologi.

Sudiono dan Arfian

1985 Kubur Prasejarah di Liang Bua, Flores Barat. (Analisis Hasil Penelitian Arkeologi Nasional 1978), Skripsi. Jakarta: Fakultas Sastra, Universitas Indonesia.

Tim Jurusan Arkeologi

1998 Ekskavasi Arkeologi di Situs Pacung, Tejakula Buleleng. Laporan Penelitian.

Denpasar: Fakultas Sastra, Universitas Udayana.

Wirastri, Sri

1990 Pola Kubur Tanpa Wadah, Situs Liang Bua, Gilimanuk, Plawangan dan Anyer. Skripsi. Jakarta: Fakultas Sastra, Universitas Indonesia. 


\title{
Short Report on the Microscopic Examination of Bone Samples from a Neolithic Burial
}

\author{
Michael Schultr
}

\section{Introduction}

Microscopic analysis of archaeological skeletal remains leads both to diagnoses of ancient diseases, and to improved age determinations (e.g., Kerley 1965; Kerley and Ubelaker 1978; Schultz 1986, 2001, 2003; Stout 1992; Wolf 1999). Additionally, changes can be detected at the micro-level which provide insights into pathological conditions resulting from every-day life, such as inactivity atrophy, which macroscopically might not be clearly observable (Schultz 1986, 1997, 2001, 2003). Also, the effects of heat and fire, occurring perimortem or postmortem, produce characteristic changes in the microstructure of bones (Grimm and Strauch 1959; Piepenbrink and Herrmann 1988; Schultz 1986, 1997, 2001, 2003; Teschler-Nicola and Schultz 1984). In the case of small bone fragments, it may not be clear whether they are of human or other animal origin. The histological analysis of bone samples can establish their identity (Harsányi 1978, 1993; Schultz 2001). Furthermore, microscopic examination of ancient bone samples can frequently yield important information as to the state of preservation and the kind of postmortem destruction (e.g., Hackett 1981; Schultz 1986, 1994, 1997, 2001, 2003; Stout and Teitelbaum 1976), necessary for the dating of the archaeological bones by the radiocarbon technique, or for molecular work, for instance, on ancient 
DNA and collagenous and non-collagenous bone proteins (Schmidt-Schultz and Schultz

2004, 2005, 2007), or examination of trace elements and stable isotopes (e.g., Hotz 2002; Schultz 1986, 1997).

Reliable diagnoses are the basis of etiology and epidemiology of diseases in past populations. However, this is not always easy. As a rule, paleopathologists can only examine the vestiges of ancient diseases in dry bones. There are no soft tissues or cells, which play such an important role in pathological investigations on recent materials, which could be studied to establish a reliable diagnosis or for comparative purposes. When archaeological skeletal remains are studied by macroscopy alone or even additionally by radiological techniques, the rate of false diagnoses is still high. Therefore, special methods and techniques, particularly at the microscopic level, need to be established to render such diagnoses more reliable (Schultz 2001, 2003).

Remark: We should keep in mind that the results of the microscopic investigation of two small samples, only a few square centimetres in size from two long bones are not representative enough to characterize the health condition of one individual and certainly not of the whole population.

\section{Materials and Methods}

Two samples which were taken from the burial PCN-IV Skeleton 6 (see Drawatik this volume) (right femur and left humerus) of the Neolithic cemetery of Pacung, northern Bali (Indonesia), were X-rayed and then investigated using low power microscopy and thin ground section microscopy. As archaeological bone might be, as a rule, fragile and extremely brittle, the technique of choice for the microscopic examination is the preparation of undecalcified thin ground sections (e.g., Hackett 1976; Stout 1992; Schultz 1986, 2001, 2003). To produce thin ground sections for light microscopy, a special technique was established based upon the method of plastination developed by Hagens (1979), but modified for histological purposes by Michael Brandt and Michael Schultz working on archaeological specimens (cf. Schultz 1988, 2001). The embedding medium is a special epoxy resin $\left(\right.$ Biodur $\left.^{\circledR}\right)$.

The embedded samples were mounted on a glass slide, cut with a special circular saw (Dr. Steeg and Reuter, Frankfurt am Main) and ground down to a thickness of $70 \mu \mathrm{m}$ and $50 \mu \mathrm{m}$ (unstained thin ground sections examined in plane or polarized light) with the same saw using a special circular disk (cf. Schultz 1988, Schultz and Drommer 1983). Thus, from each sample two sections were available for light microscopic research.

The thin ground sections were examined by transmission microscopy in plane and polarized light using the light microscope DMRXP (Leica). Thus, the nature of possible pathological structures could be relatively easily detected. The use of 
polarized-light microscopy is very useful for examining ground sections produced from dry bone samples to identify collagen fibres and the special pattern of mineralized structures in normal and pathologically changed bones. The use of a hilfsobject red $1^{\text {st }}$ order (quartz) as compensator (cf. Schultz 1988) yields more information on the features of macerated bone and ossified soft tissues because various structures, for instance, collagen fibres in poorly preserved bone structure and their orientation as well as agents and products of diagenesis, such as crystals, and remains of flora and fauna, are better observable (Schultz 1997).

The age of the individuals was checked by the histomorphological and the histomorphometric method (e.g., Kerley 1965; Kerley and Ubelaker 1978; Wolf 1999).

\section{Results}

\section{Taphonomy}

The X-ray images show slight radiopaque spots which suggest diagenetic influences. Therefore, all four thin ground sections were studied for alterations due to diagenesis (taphonomy). The quality of the preservation of the inorganic materials (mineralized structures) of the bony tissue is relatively good (Photos 1a, 1b, 3a, $3 \mathrm{~b}$ ), however, the preservation of the organic materials (e.g., bone collagen fibres) is fair to poor (right femur: Photos 1 and 2) and poor (left humerus: Photo 3).

As a rule, diagenesis occurs in bones after the process of decomposition and is associated with characteristic morphological features of decay.

Sometimes bones might be preserved in the ground by protective surroundings. This did not happen in the case of these two samples. Both samples show relatively advanced diagenetic destruction of their microstructure due to the growth of algae (Photos 1d, 2a-b, 2d, 3c) which led to the partial loss of original organic materials, such as bone collagen. Thus, the skeletons apparently remained over a relatively long time period in muddy or wet earth (e.g., shore of a lake or the sea). However, the process of diagenesis worked slowly and incompletely. In both samples, the algae growth infiltrated the compact bone substance from the external (periosteal) and the internal (endosteal) surfaces (Photos 1c, 3b), as well as from the lumina of the blood vessel canals (Haversian canals: Photos 1d, 2a, 2b, $3 \mathrm{c})$. There is another interesting taphonomic feature. In some blood vessel canals, particularly in the humerus sample and, here, in the central and the endosteal area of the compact bone substance, there is evidence of a circumscribed secondary crystallization process which is characterized by the aggregation of crystals which filled the lumina of the blood vessel canals (Photos 3b, 3c). This phenomenon cannot be mistaken for the beginning of a fossilization process but is due to the reactions between the degradation process of soft tissue remains and the surrounding soil (cf. Schultz 2001). 
Additionally, there is evidence of long lasting soil pressure which caused microfractures (cracks) in the compact bone substance of both samples (Photos 1d, 2b).

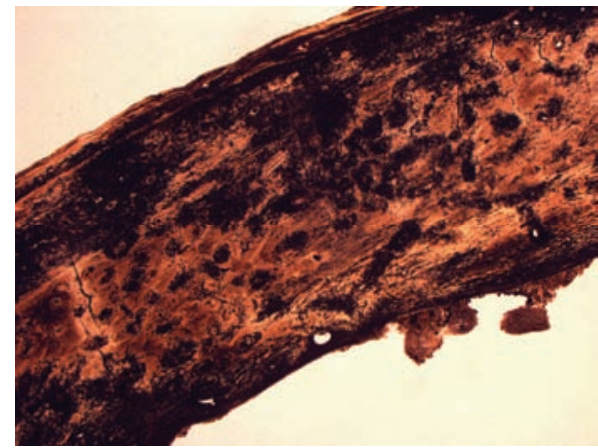

Photo 1a) Bali femur: Overview of the cross section. Undecalcified thin ground sections $(70 \mu \mathrm{m})$ viewed through the microscope in plane transmission light. Magnification 16x.

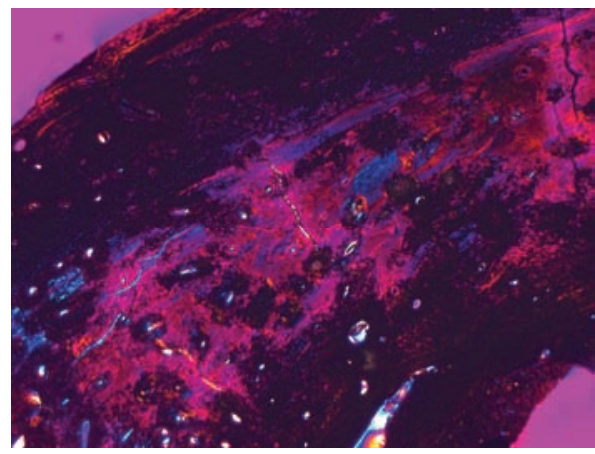

Photo 1c) Bali femur: Close up of the cross section. Region of the external and the internal circumferential lamellae relative severely affected by diagenesis (dark zones). Undecalcified thin ground sections $(70 \mu \mathrm{m})$ viewed through the microscope in polarized transmission light using a hilfsobject red $1^{\text {st }}$ order (quartz) as compensator. Magnification 25x.

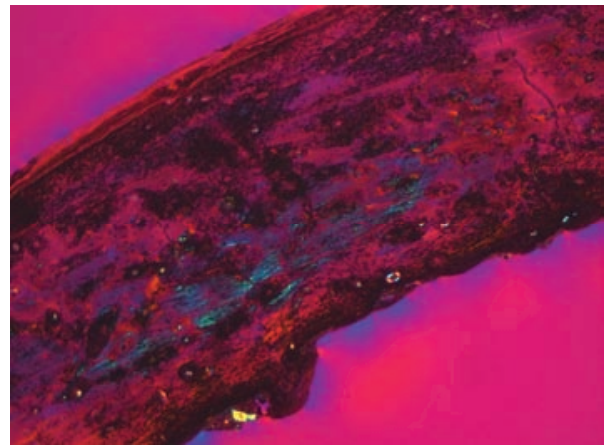

Photo 1b) Bali femur: Overview of the cross section. Undecalcified thin ground sections $(50 \mu \mathrm{m})$ viewed through the microscope in polarized transmission light using a hilfsobject red 1st order (quartz) as compensator. Magnification 16x.

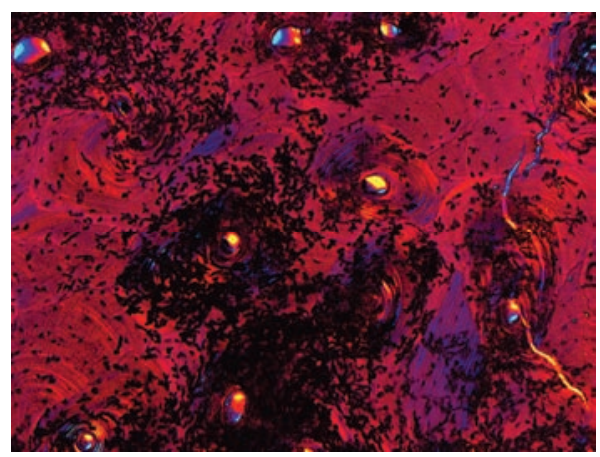

Photo 1d) Bali femur: Haversian systems (osteons) affected by postmortem tunneling due to algae growth (diagenesis). Almost complete loss of collagen fibers. Micro-fractures (cracks) due to postmortem soil pressure. Undecalcified thin ground sections $(50 \mu \mathrm{m})$ viewed through the microscope in polarized transmission light using a hilfsobject red $1^{\text {st }}$ order (quartz) as compensator. Magnification 100x. 


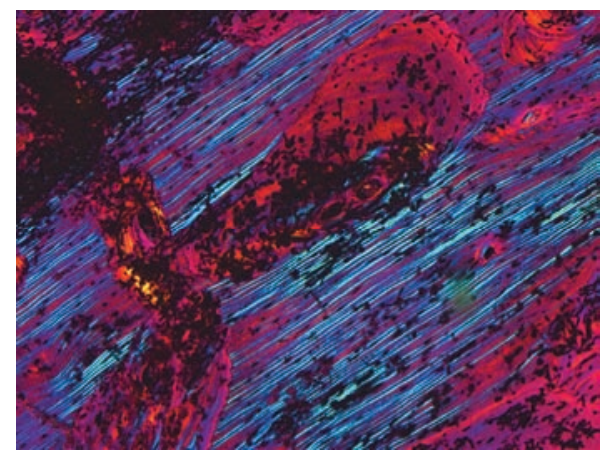

Photo 2a) Bali femur: Individual from burial PCN-IV Skeleton 6. Cross sections through femur sample. Remains of Haversian systems (osteons) and relatively well preserved tangential lamellae. In this area, collagen fibers are relatively well preserved. Undecalcified thin ground sections $(50 \mu \mathrm{m})$ viewed through the microscope in polarized transmission light using a hilfsobject red $1^{\text {st }}$ order (quartz) as compensator. Magnification $100 \mathrm{x}$.

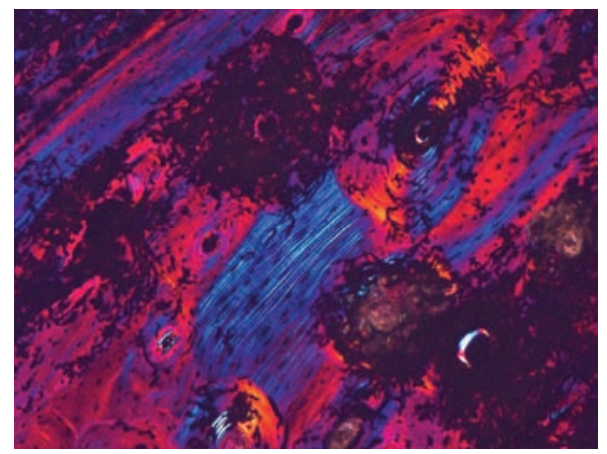

Photo 2c) Bali femur: Relatively well preserved external circumferential lamellae with blood vessel impression. Tunneling due to postmortem algae growth (diagenesis). Undecalcified thin ground sections $(50 \mu \mathrm{m})$ viewed through the microscope in polarized transmission light using a hilfsobject red 1st order (quartz) as compensator. Magnification 100x.

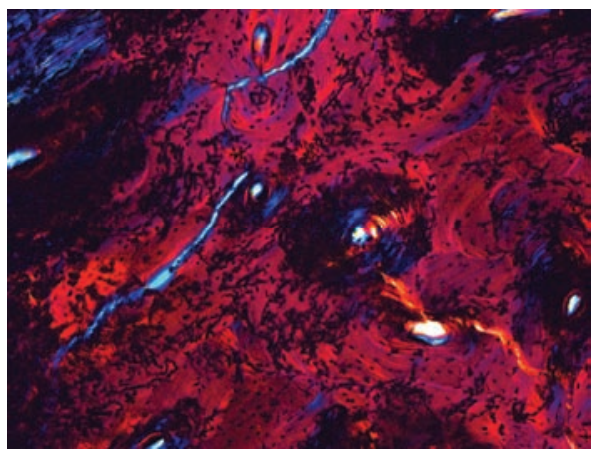

Photo 2b) Bali femur: Haversian systems (osteons) affected by postmortem tunneling due to algae growth (diagenesis). Almost complete loss of collagen fibers. Micro-fractures (cracks) due to postmortem soil pressure. Undecalcified thin ground sections $(70 \mu \mathrm{m})$ viewed through the microscope in polarized transmission light using a hilfsobject red $1^{\text {st }}$ order (quartz) as compensator. Magnification 100x.

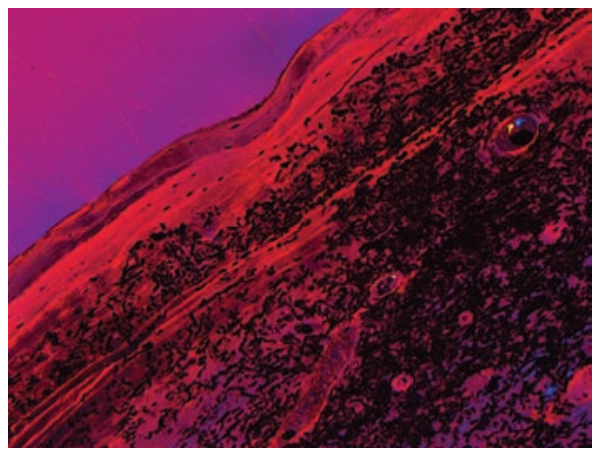

Photo 2d) Bali femur: Haversian systems (osteons) and tangential lamellae partially affected by postmortem tunneling due to algae growth (diagenesis). Undecalcified thin ground sections $(70 \mu \mathrm{m})$ viewed through the microscope in polarized transmission light using a hilfsobject red 1st order (quartz) as compensator. Magnification 100x. 


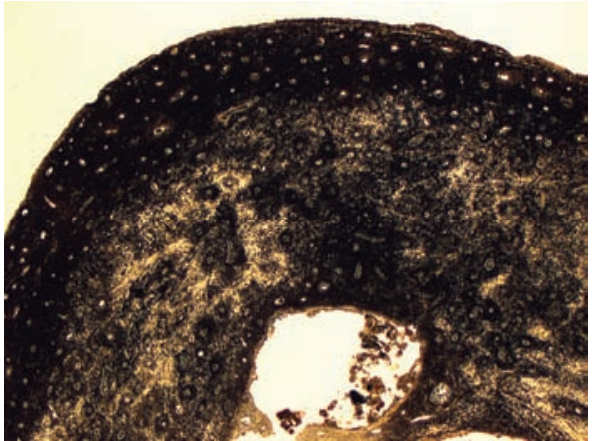

Photo 3a) Bali humerus : Overview of the cross section. Undecalcified thin ground sections $(50 \mu \mathrm{m})$ viewed through the microscope in plane transmission light. Magnification 16x

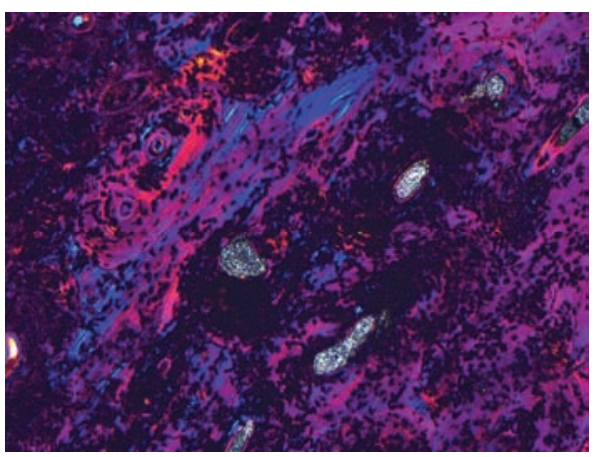

Photo 3c) Bali humerus : Haversian systems (osteons) and remains of tangential lamellae partially severely affected by postmortem tunneling due to algae growth (diagenesis). Crystals in Haversian canals in the middle and the endosteal area of the compact bone substance as product of diagenesis. Undecalcified thin ground sections $(50 \mu \mathrm{m})$ viewed through the microscope in polarized transmission light using a hilfsobject red $1^{\text {st }}$ order (quartz) as compensator. Magnification $100 \mathrm{x}$.

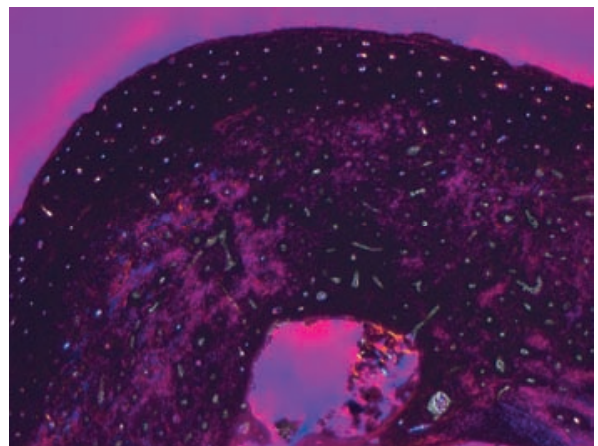

Photo 3b) Bali humerus: Overview of the cross section. Note postmortem crystals in Haversian canals as product of diagenesis. Undecalcified thin ground sections $(50 \mu \mathrm{m})$ viewed through the microscope in polarized transmission light using a hilfsobject red 1st order (quartz) as compensator. Magnification $16 \mathrm{x}$

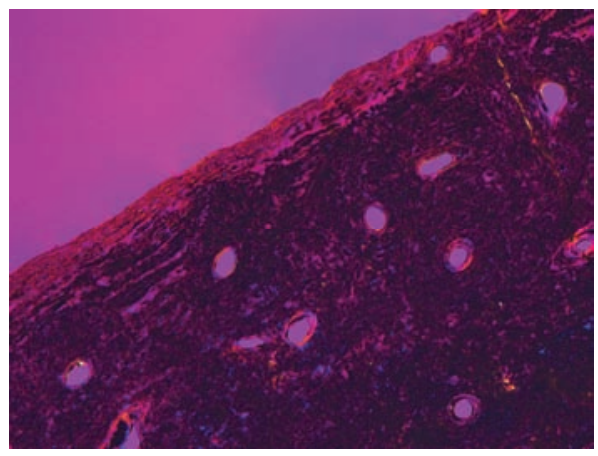

Photo 3d) Bali humerus : Relatively poorly preserved incomplete external circumferential lamellae. Tunneling due to postmortem algae growth (diagenesis). Undecalcified thin ground sections $(50 \mu \mathrm{m})$ viewed through the microscope in polarized transmission light using a hilfsobject red 1 st order (quartz) as compensator. Magnification 100x. 


\section{Microscopic Age Determination}

Using thin ground sections which were produced from samples taken from the two long bone fragments (Photos $1-3$ ), the age at death was estimated by the micro-morphometric and the micro-morphological age determination. Four morphological features were studied: 1) Haversian systems (= osteons), 2) fragmented osteons, and 3) non-Haversian systems, as well as 4) the external and the internal circumferential lamellae. If we start with the most important structure of the compact bone substance which is represented by the osteon or Haversian system, we observe that in both long bone samples most of the osteons show a regular shape and size as well as canals characteristic of individuals of the juvenile or young adult age group (Photos 1d, 2b, 3c). Large sized blood vessel canals or resorption holes which would be characteristic of the mature and senile age groups are missing. The external circumferential lamellae is very well developed. In the sample taken from the femur (Photo 2c), the external circumferential lamellae are better preserved than in the sample taken from the humerus (Photos 3c). The internal circumferential lamellae are not as well developed (Photos 1b, 3b) and in the sample from the humerus not very well preserved.

Thus, the estimated age of the samples from burial PCN-IV S 6 is 15-20 (10) years for the right femur and 15-20 (25) years for the left humerus. Therefore we can assume a core age of 15-20 years for this individual.

\section{Pathology}

Bone surfaces of the two samples representing small fragments of the right femur and left humerus of the individual from burial PCN-IV SK6 were investigated by magnifying glass and a low power binocular microscope. No vestiges of pathological conditions were observed on the external surfaces.

$\mathrm{X}$-ray images did not reveal any pathological conditions.

Despite the relatively poor preservation of the two samples, a microscopic investigation of all four ground sections was carried out to diagnose vestiges of diseases or pathological conditions. There is no evidence of vestiges of systemic deficiency diseases or inflammatory processes.

\section{Summary}

Two long bone samples (femur, humerus) of one individual from the Neolithic site of Pacung in northern Bali (Indonesia) were investigated using macroscopic, low power microscopic, radiological and light microscopic techniques including polarizing microscopy. The age was estimated by histomorphological and histomorphometric age determination to be $15-20$ (10) years (femur) and $15-20$ (25) years (humerus). The compact bone substance of the two samples showed pronounced diagenetic changes mainly due to the growth of algae which had infil- 
trated the compact bone substance from all external and internal surfaces which suggests that the burials had been interred in wet earth. There is influence of mild soil pressure expressed by some micro-fractures. Vestiges of pathological processes were not observed.

\section{Acknowledgments}

The author wishes to thank Michael Brandt and Ingrid Hettwer-Steeger (Department of Anatomy, University of Göttingen, Germany) for preparing the ground sections and Cyrilla Maelicke (Department of Histology, University of Göttingen, Germany) for reading the English text. Furthermore, the author thanks Brigitta Hauser-Schäublin for bone samples from the burial PCN-IV SK6 excavated at Pacung in 2002 and important archaeological information.

\section{References}

Grimm, H. und R. Strauch

1959 Schliffuntersuchungen am Knochen zum Nachweis einer Feuerbehandlung bei der Bestattung. Ausgrabungen und Funde 4: 262-264.

Hackett, C.J.

1976 Diagnostic Criteria of Syphilis, Yaws and Treponarid (Treponematoses) and some other Diseases in Dry Bones. Sitzberichte der Heidelberger Akademie der Wissenschaften, Bd. 4; pp. 1-124. Berlin: Springer.

1981 Microscopical Focal Destruction (Tunnels) in Exhumed Human Bones. Medicine, Science and the Law 21: 234-265.

Hagens, G. v.

1979 Impregnation of Soft Biological Specimens with Thermostetting Resins and Elastomers. The Anatomical Record 194: 247-255.

Harsányi, L.

1978 Unterscheidung von Menschen- und Tierknochen. In: Hunger, H. and D. Leopold (Hg.): Identifikation; pp. 100-112. Leipzig: JA Barth.

1993 Differential Diagnosis of Human and Animal Bone. In: Grupe, G. and A.N. Garland (eds.): Histology of Ancient Human Bone: Methods and Diagnosis; pp. 79-94. Berlin: Springer Verlag:

Hotz, G.

2002 Die Bestattungsplätze des Klosters St. Johann - Anthropologische Auswertung einer frühmittelalterlichen bis neuzeitlichen Skelettserie unter spezieller Berücksichtigung spurenelementanalytischer Fragestellungen. Diss. phil., Universität Basel.

Kerley, E.R.

1965 The Microscopic Determination of Age in Human Bone. American Journal of Physical Anthropology 23: 149-163. 
Kerley, E.R. and D.H. Ubelaker

1978 Revision in the Microscopic Method of Estimating Age at Death in Human Cortical Bone. American Journal of Physical Anthropology 49: 545-546.

Piepenbrink, H. and B. Herrmann

1988 Behandlung überdauerter Weichgewebe. In: Knussmann, R. (Hg.): Anthropologie. Handbuch der vergleichenden Biologie des Menschen, Bd. 1, 1; pp. 571-576. Stuttgart, New York: G. Fischer.

Schmidt-Schultz, T.H. and M. Schultz

2004 Bone Protects Proteins over Thousand of Years: Extraction, Analysis, Interpretation of Extracellular Matrix Proteins in Archaeological Skeletal Remains. American Journal of Physical Anthropology 123: 30-39.

2005 Intact Growth Factors are Conserved in the Extracellular Matrix of Ancient Human Bone and Teeth: a Storehouse for the Study of Human Evolution in Health and Disease. Biolological Chemestry 386: 767-776.

2007 Well Preserved Non-collagenous Extracellular Matrix Proteins in Ancient Bone and Teeth. International Journal of Osteoarchaeology 17: 91-99.

Schultz, M.

1986 Die mikroskopische Untersuchung prähistorischer Skeletfunde. Anwendung und Aussagemöglichkeiten der differentialdiagnostischen Untersuchung in der Paläopathologie. Archäologie und Museum 6. Liestal: Kanton Baselland.

1988 Methoden der Licht- und Elektronenmikroskopie. In: Knussmann, R. (Hg.): Anthropologie. Handbuch der vergleichenden Biologie des Menschen, Bd. 1, 1; pp. 698-730. Stuttgart, New York: G. Fischer.

1994 Ergebnisse mikroskopischer Untersuchungen an archäologischen Skeletfunden. Ein Beitrag zur Paläopathologie. Beiträge zur Archäozoologie und prähistorischen Anthropologie. In: Kokabi, M. and J. Wahl (Hg.): Forschungen und Berichte zur Vor- und Frühgeschichte in Baden-Württemberg, Bd. 53; pp. 107116. Stuttgart: Theiss.

1997 Microscopic Investigation of Excavated Skeletal Remains: A Contribution to Paleopathology and Forensic Medicine. In: Haglund, W.D. and M.H. Sorg (eds.) Forensic Taphonomy. The Postmortem Fate of Human Remains; pp. 201-222. Boca Raton [u.a.]: CRC Press.

2001 Paleohistopathology of Bone: A New Approach to the Study of Ancient Diseases. American Journal of Physical Anthropology 33: 106-147.

2003 Light Microscopic Analysis in Skeletal Paleopathology. In: Ortner, D.J. (ed.): Identification of Pathological Conditions in Human Skeletal Remains; pp. 73-108. Amsterdam [u.a.]: Academic Press, Elsevier Science.

Schultz, M. and R. Drommer

1983 Möglichkeiten der Präparateherstellung aus dem Gesichtsschädelbereich für die makroskopische und mikroskopische Untersuchung unter Verwendung neuer Kunststofftechniken. In: Hoppe, W.G. (Hg.): Fortschritte der Kiefer- und Gesichts-Chirurgie, Bd. 28; pp. 95-97. Experimentelle Mund-Kiefer-GesichtsChirurgie. Mikrochirurgische Eingriffe. Stuttgart, New York: G. Thieme. 
Stout, S.D.

1992 Methods of Determining Age at Death Using Bone Microstructure. In: Saunders, S.R. and M.A. Katzenberg (eds.): Skeletal Biology of Past Peoples. Research Methods; pp. 21-35. New York: Wiley-Liss.

Stout, S.D. and S.L. Teitelbaum

1976 Histological Analysis of Undecalcified Thin Sections of Archaeological Bone. American Journal of Physical Anthropology 44: 263-70.

Teschler-Nicola, M. and M. Schultz

1984 Jungneolithische Skelette der Badener Kultur aus Leobersdorf und Lichtenwörth, Niederösterreich. Annalen des Naturhistorischen Museums Wien, Bd. 86; pp. 111-144. Wien.

Wolf, M.

1999 Ergebnisse makro- und mikroskopischer Untersuchungen an den römischen Brandgräbern von Rheinzabern (Rheinland-Pfalz). In: Schultz, M. (Hg.): Beiträge zur Paläopathologie, Bd. 3. Göttingen: Cuvillier Verlag. 


\title{
Excavation in Julah's Temporary Settlement of Upit
}

\author{
I Ketut Setiawan and Rochtri Agung Bawono
}

\section{Introduction}

The northern part of Bali, especially the District of Tejakula, Buleleng Regency, encompassing the villages of Pacung, Sembiran and Julah, is a treasure trove of historical data such as prehistoric sites and inscriptions dating from the Bali Kuna (ancient Bali) era.

Further proofs of prehistoric civilization in this area are findings of a number of stone articles from the Palaeolithic Age in the Sembiran area such as: chopper, hand-adze, proto hand axe, core tool, hammer and scrapers (Soejono 1962). Another discovery is a terraced structure that may be similar to those in the megalithic age, upright stone and natural stones arranged in a pile. The terraced stone structure is believed to have been used as a site to pay homage to ancestors and to ask for safety and plenty for the living community (Sutaba 1976; 1980).

In the Classical Age Julah is mentioned in copperplate inscriptions of the Bali Kuna between the $10^{\text {th }}$ and $12^{\text {th }}$ centuries $A D$ written in the Bali Kuna or sometimes Java Kuna language (see Setiawan this volume). The inscriptions so far discovered amount to 20 pieces. Ten of them are kept in Sembiran and 10 in Julah (Goris 1954). The edicts contained in these inscriptions deal with the rights and the responsibilities of the people of Julah in relation to the kings of Bali Kuna (Brandes 1889). Based on the findings of these inscriptions, we can safely assume that the village life of Julah at that time was highly developed; Julah could even be 
considered a port town with its own representative market to conduct commerce (see Ardika this volume). As a port town Julah was visited by both local and foreign merchants that came to Julah in boats and ships and other (unknown) sea going vessels named as lancing and talaka (Santoso 1965).

Archaeological studies have only rarely been carried out in Julah with the exception of one systematic study in 1987. This excavation opened only one trench, Julah I (JLH I), with the discovery of a few earthenware fragments, Chinese ceramics and animal bone fragments. The find was concentrated at spit 9 and 10, or at the third layer (Ardika 1988; 1991).

The excavation at Julah was prompted by an interest in knowing the whereabouts of ancient villages described in the inscriptions found in Sembiran. The discovery of Chinese ceramic fragments in the hamlet of Batu Gambir in 1980 by local people raised hopes of finding archaeological data on Julah in the Bali Kuna age.

From an administrative point of view, the Batu Gambir excavation site is located in the village area of Julah, sub-district of Tejakula, Buleleng Regency, in hilly terrain. According to the local people, Batu Gambir was once the site of Julah's main temple, Pura Bale Agung (see Hauser-Schäublin this volume). The traditional term for this whole area is Upit, a name already mentioned in the copperplate inscriptions. Upit probably was a site where Julah's villagers fled to when they suffered attacks by enemies from the sea. Batu Gambir is a recent name given to the hamlet where today Muslim as well as Hindu immigrants from other parts of Bali live.

Batu Gambir (see Figure 1, Hauser-Schäublin this volume) sits on the crest of a hill with the west and east side falling steeply away into the rivers below. Julah is located on a flat strip of land near the coast. Today, the land of Julah's former refugee settlement is laba pura land (temple land) owned by the desa pakraman (core villagers) of Julah. The land is cultivated by growing cassava, nuts, bananas, mangoes, coconuts, avocados, rambutans, cloves, coffee beans and cocoa trees. The local community lives off this produce and from cattle farming.

Geologically, Julah is situated on the northern Bali mountain range, which is a part of the "Zone Solo" in Java. This is a volcanic range formed in the Pleistocene Age. Within this zone is found the Mount Batur complex, whose lava route runs in a northerly direction through Sembiran, Pacung, Julah, and Bondalem and through the rivers in that area (Poesponegoro and Notonegoro 1984).

According to the geological map of Bali - Nusa Tenggara, Julah shows two geological characteristics:

The formation Asah consisting of lava rocks, volcanic breccia and tuff stone, side by side with karst sediment.

The volcanic formation of the Buyan-Bratan-Batur mountain ranges from tuff and lava (Purbo-Hadiwidjojo et al. 1998). 
The Asah formation is located in lower Julah while the volcanic formation of the Buyan-Bratan-Batur group is in upper Julah.

On the basis of Bali's hydrogeology map, drawn to a scale of 1:250.000, Julah has a variety of water resources. The coast closer to lower Julah has local water resources with a spring discharge of $0.1 \mathrm{lit} / \mathrm{sec}$, located in the lava area. Upper Julah has local water resources with a spring discharge of 1 lit/sec (PurboHadiwidjojo 1971). The smaller water source is found to the east of Batu Gambir with a spring discharge of less than $10 \mathrm{lit} / \mathrm{sec}$ and is called the source of the Upit. This is a sacred well: the tirta (sacred water) is taken for religious ceremonies. East of Upit is a waterfall used by local people for their daily needs.

\section{The Archaeological Investigation}

The excavation at Batu Gambir Site in 2004 was the first made there. It would be important to know more about or to test the spit, i.e. about the general state of the structure and layers of the earth.

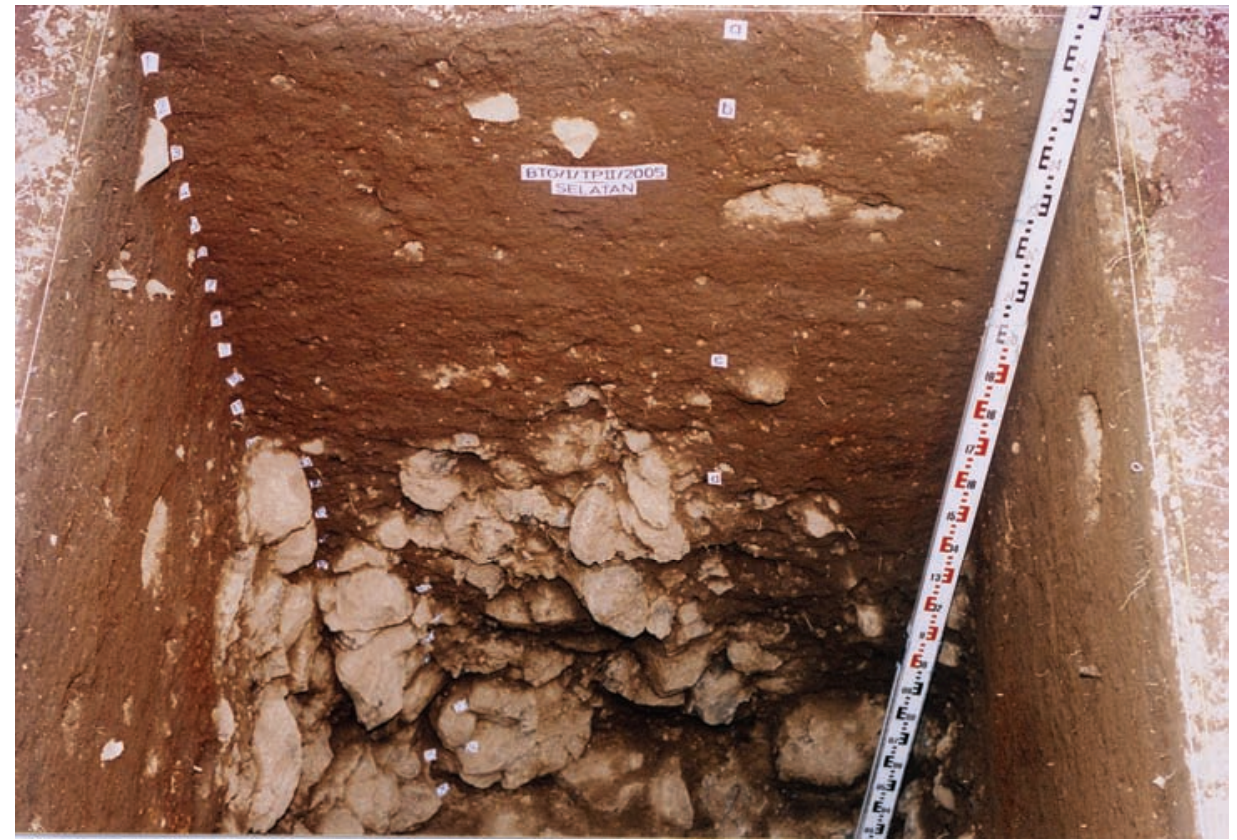

Photo 1: Test Pit II in Batu Gambir displaying the stratigraphy with a layer of stones at the bottom. Photo: Tim Jurusan Arkeologi 2005. 
The procedures and results of the excavation are as follows:

Square Test Pit (TP I)

Located approximately $378 \mathrm{~m}$ above sea level in the cultivated land owned by the Desa Pakraman Julah, approximately $400 \mathrm{~m}$ from Batu Gambir Mosque. The quality of the soil is good because the land is constantly cultivated by the people for planting.

The square is $1.5 \times 1.5 \mathrm{~m}$ and dug using the spit method with each spit $10 \mathrm{~cm}$ deep, excluding the first spit which is $15 \mathrm{~cm}$ in depth from the datum line (string level).

The condition of the soil has been identified as having four characteristic layers (from top down) as follows:

Humus/top soil, light brown with a yellowish tinge colour

Humus/top soil, brown blackish colour

Mixture of sand and tuff stone, brown colour

Mixture of volcanic stone and clay, brownish colour

Layer "a" is of humus/top soil down to about $15 \mathrm{~cm}$ in depth and is mostly cultivated and used for farming. Its texture is medium with a light brown yellowish tinge. Between $15 \mathrm{~cm}-40 \mathrm{~cm}$ in depth, the soil's texture is still medium but with a change of colour to brown blackish. Both can still be called humus but the difference is in the humidity of the soil. After a depth of $40 \mathrm{~cm}-60 \mathrm{~cm}$ the soil changes to rough, as it becomes a mixture of sand and tuff stone, brownish in colour.

At a depth of $60 \mathrm{~cm}-160 \mathrm{~cm}$ the soil condition changes to a mixture of volcanic stone and sand making its texture very coarse and brown in colour. The digging terminates at a depth of $170 \mathrm{~cm}$ volcanic rocks start.

Discovered at TP I have been: earthenware fragments, Chinese ceramics fragments, coal residue, coin fragments, animal bones and teeth fragments. Also fragments of pottery such as: lip, rim, carination, body and base from top spit to spit 13 with greater population at spit 5 to spit 9. Coal was found at spit 6, 8, 9, and 11 (see Table 1 below).

The greatest variety of items was yielded between spits 4 to 9 . 
Table 1: Items Found in TP I

\begin{tabular}{|c|c|c|c|c|c|c|}
\hline \multirow[b]{2}{*}{ Layer } & \multirow[b]{2}{*}{ Spit } & \multicolumn{5}{|c|}{ Result } \\
\hline & & $\begin{array}{c}\text { Earthenware } \\
\text { Fragment }\end{array}$ & $\begin{array}{c}\text { Ceramic } \\
\text { Fragment }\end{array}$ & $\begin{array}{l}\text { Bone } \\
\text { Fragment }\end{array}$ & $\begin{array}{l}\text { Coal Resi- } \\
\text { due }\end{array}$ & $\begin{array}{c}\text { Metal (coin) } \\
\text { Fragment }\end{array}$ \\
\hline \multirow{3}{*}{ A } & Surface & 24 & 3 & - & - & - \\
\hline & 1 & 29 & 3 & - & - & - \\
\hline & 2 & 30 & - & - & - & - \\
\hline \multirow{2}{*}{ B } & 3 & 11 & - & - & - & - \\
\hline & 4 & 24 & 1 & 1 & - & - \\
\hline \multirow{2}{*}{ C } & 5 & 50 & 2 & - & - & - \\
\hline & 6 & 41 & 3 & 1 & $2 \mathrm{~g}$ & $1 \mathrm{~g}$ \\
\hline \multirow{8}{*}{ D } & 7 & 61 & 2 & - & - & - \\
\hline & 8 & 64 & 2 & 1 & $20 \mathrm{~g}$ & $0.5 \mathrm{~g}$ \\
\hline & 9 & 52 & 1 & 1 & $2 \mathrm{~g}$ & - \\
\hline & 10 & 23 & 2 & - & - & - \\
\hline & 11 & 18 & 1 & - & $2 \mathrm{~g}$ & - \\
\hline & 12 & 26 & 2 & - & - & - \\
\hline & 13 & 4 & 2 & - & - & - \\
\hline & 14 & - & - & - & - & - \\
\hline \multicolumn{2}{|l|}{ Total } & 457 & 24 & 4 & $26 \mathrm{~g}$ & $1.5 \mathrm{~g}$ \\
\hline
\end{tabular}

\section{Square Test Pit (TP II)}

Located at approximately $375 \mathrm{~m}$ above sea level, $28 \mathrm{~m}$ north of square TP I. Soil condition can be said to be the same as in square TP I.

The trench is $1.5 \times 1.5 \mathrm{~m}$ and dug using the spit method with each spit $10 \mathrm{~cm}$ deep, excluding the first spit, which is $15 \mathrm{~cm}$ in depth from the datum line (string level). The dig goes down to $270 \mathrm{~cm}$ from the surface.

The condition of the soil has been identified as having four characteristic layers (from top down), as follows:

Humus/top soil, light brown colour

Sandy clay particles, brown colour

Mixture of clay and tuff stone, brown-reddish colour

Mixture of andesit, volcanic breccia, and clay layer, brownish colour

Layer "a", humus/top soil, is mostly cultivated to a depth of $20 \mathrm{~cm}$, light brown with yellow a tinge. From a depth of $20 \mathrm{~cm}-100 \mathrm{~cm}$ the soil condition changes to a sandy soil of brownish colour with a medium texture. Layer "c" is at a depth of $100 \mathrm{~cm}-130 \mathrm{~cm}$, the soil consisting of tuff stone, rough texture and brown to reddish in colour. 
Layer "d" is at a depth of $130 \mathrm{~cm}-270 \mathrm{~cm}$ and is a mixture of andesit and volcanic breccia. Digging stopped at this level because of the overall rocky condition, and no artefacts were found.

At TP II, between the top-most spit and spit 5 at $60 \mathrm{~cm}$ from string level, there were found earthenware fragments (lip, rim, and neck), Chinese ceramics fragments, coal residue and bone fragments. Earthenware was then uncovered at spit 24 (see Table 2).

Table 2: Items Found in TP II

\begin{tabular}{|l|l|l|l|l|l|l|}
\hline \multirow{3}{*}{ Layer } & \multirow{2}{*}{ Spit } & \multicolumn{6}{|c|}{ Result } \\
\cline { 3 - 8 } & & $\begin{array}{l}\text { Earthenware } \\
\text { Fragments }\end{array}$ & $\begin{array}{l}\text { Ceramic } \\
\text { Fragments }\end{array}$ & $\begin{array}{l}\text { Bone Frag- } \\
\text { ments }\end{array}$ & $\begin{array}{l}\text { Coal Resi- } \\
\text { due }\end{array}$ & $\begin{array}{l}\text { Metal (coin) } \\
\text { Fragments }\end{array}$ \\
\hline \multirow{3}{*}{$\mathrm{a}$} & $\mathrm{P}$ & 3 & 3 & - & - & - \\
\cline { 2 - 8 } & 1 & 43 & 6 & - & - & - \\
\cline { 2 - 8 } & 2 & 30 & 7 & 5 & - & - \\
\hline b & 3 & 11 & 1 & - & - & - \\
\cline { 2 - 8 } & 4 & 26 & - & - & $5 \mathrm{~g}$ & - \\
\cline { 2 - 8 } & 5 & 4 & - & - & - & - \\
\hline $\mathrm{d}$ & 24 & 1 & - & - & - & - \\
\hline \multicolumn{2}{l}{ Total } & 118 & 17 & 5 & $5 \mathrm{~g}$ & - \\
\hline
\end{tabular}

\section{Analysis of the Artefacts}

\section{Earthenware}

Earthenware fragments made up most finds at the Batu Gambir Site. None were found intact and the largest was a $25 \mathrm{~cm} \times 8 \mathrm{~cm}$ piece found at TP I, spit 11 at a depth of $115 \mathrm{~cm}$.

Most of the fragments were plain without any decorations except for the bearing of a circular indentation, probably from a natural cause in the making of the earthenware (see Table 3 below for items uncovered at Batu Gambir Site).

Table 3: Distribution of Earthenware Fragments at Batu Gambir Site

\begin{tabular}{|l|l|l|l|l|l|l|l|}
\hline Square & Lip & Rim & Neck & Carination & Body & Base & Amount \\
\hline TP I & 34 & 40 & 24 & 23 & 317 & 19 & 457 \\
\hline TP II & 13 & 13 & 6 & 11 & 75 & $1^{*}$ & 118 \\
\hline Total & 47 & 53 & 30 & 34 & 392 & 20 & 575 \\
\hline
\end{tabular}

Note: * a decorated earthenware fragment 
From the table above it can be seen that the earthenware fragments found at TP I amounted to 457 pieces, or 79,48 \%, and at TP II 118 pieces or 20,52\%. All were plain/unadorned $(99,83 \%)$ except for the piece found at TP II with a natural indentation similar to the one found at TP I/top soil.

Of the 575 fragments found, the largest percentage, 68,17\% or 392 pieces, were parts of the body. This was followed by the rim fragments $(9,21 \%)$ or 53 pieces, lip fragments $8,17 \%$ or 47 pieces, carination fragments 5,91 or 34 pieces, neck fragments $5,21 \%$ or 30 pieces, base fragments only $3,47 \%$ or 20 pieces. These proportions were consistent at both TP I and TP II.

From the fragments of the earthenware rims found and the orientation they had, analyses were made in order to reconstruct the types and function of the earthenware. Classification falls into two categories: the upright standing rim position, either with opened or closed rim, straight or bent shape. All were plain, with the exception of natural indentation occurring in the manufacturing process.

Analytical results from the 53 outer rim fragments taken from TP I and TP II are as follows:

Table 4: Distribution of Shapes and Orientation of Earthenware Rims

\begin{tabular}{|l|l|l|l|l|l|l|l|}
\hline \multirow{3}{*}{ Square } & \multicolumn{5}{|c|}{ Shape / Orientation } & \multirow{2}{*}{ Amount } \\
\cline { 2 - 7 } & \multicolumn{3}{|c|}{ Direct (straight) } & \multicolumn{3}{c|}{ Indirect (bent) } & \\
\cline { 2 - 7 } & Opened & Upright & Closed & Opened & Upright & Closed & \\
\hline TP I & 36 & - & - & 4 & - & - & 40 \\
\hline TP II & 11 & 1 & - & 1 & - & - & 13 \\
\hline Total & 47 & 1 & - & 5 & - & - & 53 \\
\hline
\end{tabular}

Based on the table above, we can identify five types of earthenware pottery at Batu Gambir Site:

a) Plate type: the largest straight plate with an outward opening rim has a diameter of $30 \mathrm{~cm}$ at the top; the others displayed approximately $20 \mathrm{~cm}-25 \mathrm{~cm}$ in diameter. They probably functioned as a serving dish rather than a dining dish; found at TP II, spit 4.

b) Bowl type: straight outward opening bowl with a diameter of $20 \mathrm{~cm}-30 \mathrm{~cm}$, with a much thicker lip compared to its main body. Found at both TP I and TP II. Straight outward opening bowls with opened or closed lips make up a large percentage of the artefacts found; there were also found straight upright bowls with opened lips. The bowl type accounted for most of the rim fragments found.

c) Basin type with carination: with indirectly opened rim (bent shape) and upright open lip. Diameter of the lips between $15 \mathrm{~cm}-30 \mathrm{~cm}$ and a width of the opening between $4 \mathrm{~cm}-7.5 \mathrm{~cm}$; found at TP I. 
d) Lid type: found only at TP II, bent form and open lip shape. Length and diameter cannot be identified from the sherd. The shape and the size of the body of the container to which the lid belonged could not be identified either.

e) Pitcher type: identified from the neck fragments found at TP II, with a diameter of $6 \mathrm{~cm}$. Pitchers were probably used instead of pots for storing water (no pots for storing water were found at Batu Gambir Site).

We can conclude from the Batu Gambir fragments themselves and from the fact that they were undecorated that these items were kitchen utensils. Drinking cups or pots were probably made from fragile materials that were easy to break, so that no remnants can be found.

Types of earthenware not found at Batu Gambir Site TP I or TP II: cups, jars, water pots, lamps, and legged bowls.

The result of technological analysis is as follows:

a) High velocity potter's wheels were used in the making of the pottery. This can be seen from parallel horizontal lines in the inner surface. The outside surface is usually smoothed out.

b) The raw material used was mostly clay of a red brownish colour mixed with coarse particles; pores are visible and consistent in both excavation sites. Sometimes fragments were found made from a finer material with a smoother texture, reddish in colour. In conclusion the raw materials consisted of: a) coarse mixture of clay and coarse sand that resulted in large particles and b) mixture of clay and quartz. Both components act as natural adhesives making the surface smooth and solid.

c) Outer surfaces were polished either by:

1) The slip method. This is done by covering the surface with the same mixture, with or without the same colouring. An example of this type was found at the Batu Gambir Site: one fragment had a red core and a black smooth surface.

2) The polish method. Evidence of this method can be found in a neck fragment where horizontal lines that covered the outer surface create a smooth and close surface.

From the analysis above, it can be said that the earthenware fragments were made by the people in the vicinity of todays Pacung, Sembiran or Julah, with the exception of the smooth neck fragment, which in all probability came from a different place of origin. 


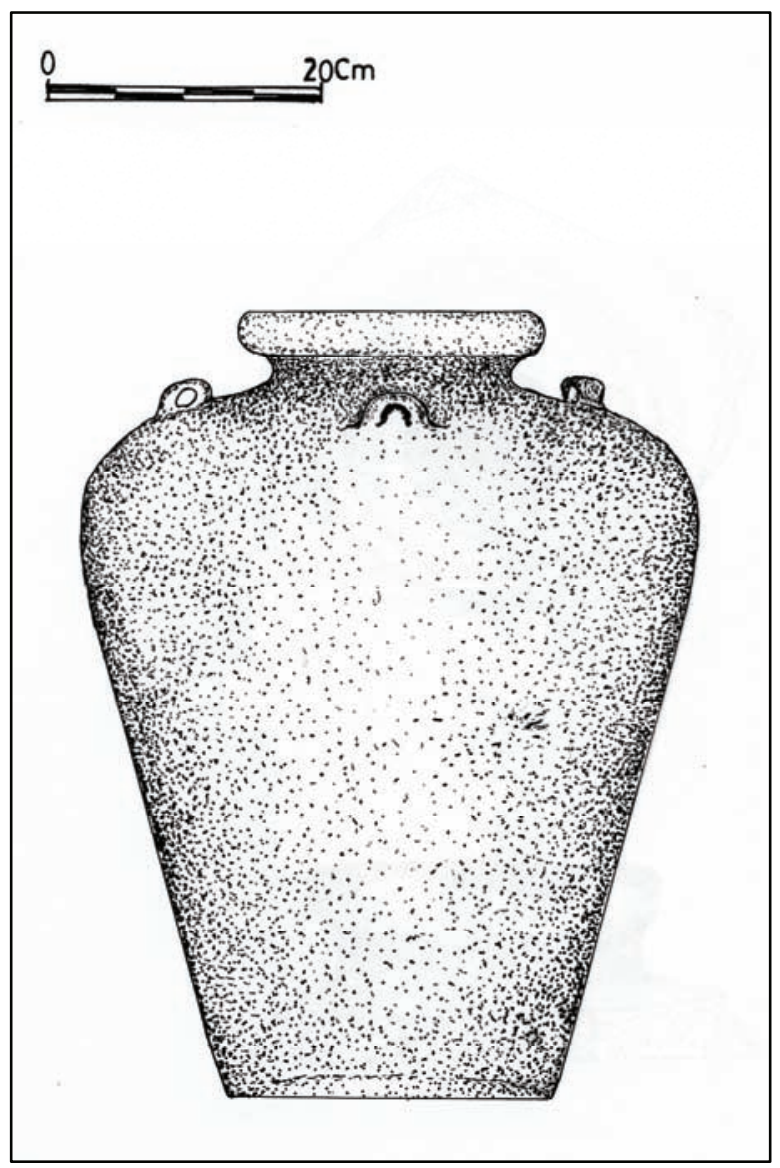

Figure 1: Drawing of a Chinese ceramic jar (Martavan type) found by a villager in Batu Gambir, Julah. Tim Jurusan Arkeologi 2005.

\section{Discovery of Chinese Ceramics}

Ceramics found in the Batu Gambir Site probably originated from China and were exchanged through commerce.

Dates when the ceramics were made can be analyzed from the type and motifs. Ceramic fragments found in TP I and TP II can be seen in the table below.

Table 5: Types of Ceramic Fragments at Batu Gambir Site

\begin{tabular}{|l|l|l|l|l|l|l|l|}
\hline Square & Lips & Rims & Neck & Carination & Body & Base & Amount \\
\hline TP I & - & 6 & - & 1 & 13 & 4 & 24 \\
\hline TP II & 6 & 1 & - & 1 & 9 & - & 17 \\
\hline Total & 6 & 7 & - & 2 & 22 & 4 & 41 \\
\hline
\end{tabular}


From a total of 41 pieces of fragments found, 22 pieces, or 53,7\%, are main body fragments, 7 pieces, or 17,1\%, rim fragments, 6 pieces, or 14,6\%, lip fragments, 4 pieces, or $9,8 \%$, base fragments and 2 pieces or $4,8 \%$ carination.

Based on the artefacts found (table 5) we can conclude that there were 3 types, their full shape in the Batu Gambir Site being as follows:

1) Plate type. Straight outward opening orientation; lips with a diameter between $20-30 \mathrm{~cm}$. Probably used for special purposes, not for everyday use, due to its beauty and luxurious quality and also economic value.

2) Bowl type. Straight, open orientation, diameter of the lips between $8-20 \mathrm{~cm}$ (found in both TP I and TP II). Variations of the bowl type can be seen in the form of the lips (opened and closed). There were also straight open, upright standing bowls with open lips. Bowls were apparently the most common ceramics found at the excavation site.

3) Small pot type (cepuk) found at spit 6 in TP I. Upright standing lip with a diameter of $8 \mathrm{~cm}$, a unique characteristic being that the lip part is thinner than the rest of the body. This is so that a lid can fit in; however, a lid could not be found.

Technical analysis shows two types of processes used in creating these objects:

1) Potter's wheel method: a characteristic of this type is that the base is not glazed, and parallel symmetrical grooves are visible.

2) Impressed technology: traces of this technique are visible on fragments that have parallel grooves in a wavy line.

Other analyses made were on the materials used and the method of glazing. It is noted that most were made from stoneware with a colouring of off-white, cream, grey or ivory, at its core and heated to a temperature of $1150-1300^{\circ} \mathrm{C}$. When made from porcelain, the inner part of the fragments has a milky or greyish white colour. It was heated to $1150-1350^{\circ} \mathrm{C}$. There are also two types of particles found: coarse and fine. Most of the fragments discovered have a fine texture.

The outer surface of these artefacts was glazed by either dipping each object into glaze liquid to make it shiny and transparent, with the exception of the base and the top of the lip.

Methods used to decorate the fragments were:

1) Paint: this is the most common decoration form. The surface of the ceramics was decorated by applying paint either with or without brush. The colour of the painted decoration differed from that of the glaze. The final colours became visible only after firing (under-glaze painting).

2) Application of the same material as used for the container on its surface.

3) Incision: incising with a sharp object on the surface until the desired picture is achieved. This method can be combined with the application method if the excised material is attached to an adjacent intact part of the surface to create a fur- 
ther decoration. There is one jar fragment that displays this method. It was used to create a dragon character (naga) with scales.

Almost all of the ceramic fragments found had some decoration except for 5 pieces. In TP I, 3 fragments were not decorated, 2 from the body and 1 from the rim. In TP II, only 2 fragments from the body were not decorated. Decoration consisted mostly of a single line, 2 parallel lines, dots, leaves, triangle, sunflower, bird wings, dragon scales and rising spirals. Judging from the variety and colour of raw materials, motifs, glaze and heated trace, the time and date of origin can be calculated for the different type of ceramic.

a) Sung Dynasty (between 960 and 1279 AD): off-white based, brown/iron-black glaze, stoneware; blue and white motifs with a bluish or rather greyish glaze; reddish or grey core. Leafs, twines and flowers as preferred decoration.

b) Yuan Dynasty (between 1279 and 1368 AD): off-white glazed, red lines on glazed base, reddish core.

c) Ming Dynasty (between 1368 and 1644 AD): blue and white motifs with vivid colours; greyish/shiny core; uneven dark-brown glaze. Application technique with motifs of dragon scales.

The ceramics with applications such as a dragon with scales and a dark-brown glaze may originate sometime between the $14^{\text {th }}$ and the $15^{\text {th }}$ century.

Wanli era (between 1572 and 1620 AD, that is Ming Dynasty): blue and white ceramic fragments from Swatow, featuring some faulty manufacture (International Field School of Archaeology 1991).

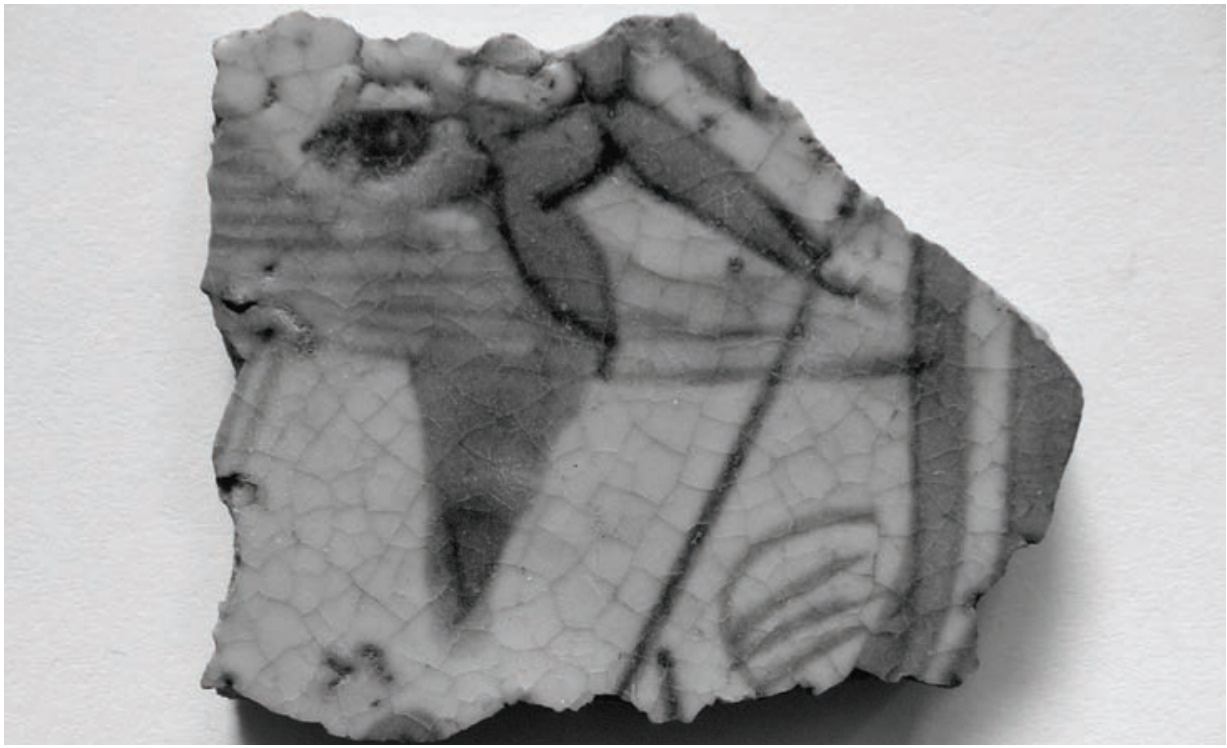

Photo 2: Chinese ceramic fragment found at the Batu Gambir Site. Photo: Jörg Hauser 2006. 


\section{Metal Fragments}

Two metal fragments of ancient Chinese coins were found in Batu Gambir Site at TP I/spit 6 (1 gram) and spit 8 (0.5 gram). Both were greenish in colour due to age. Difficult to verify origin or date, as the writings on the coins were blurred.

On the basis of these finds we can assume that the people of Old Julah, in the vicinity of Batu Gambir, were traders and used money, having progressed beyond the barter system.

Charcoal Residue

Charcoal was found in both TP I/spit 6 (2 g); spit 8 (20 g); spit 9 (2 g); and spit 11 $(2 \mathrm{~g})$; at TP II only at spit $4(5 \mathrm{~g})$. Total of 31 grams from both TP I and TP II.

\section{Organic Artefacts}

Remains of organism found at TP I and TP II consisted of bones and teeths. Further identification was difficult because of the fragile state.

At TP I spit 4 bone fragments $(2 \mathrm{~g})$; spit $6(1 \mathrm{~g})$; spit $8(1 \mathrm{~g})$; spit $9(1 \mathrm{~g})$; spit 10 $(2 \mathrm{~g})$ and at TP II spit 2 at lying close to another totalling 3 grams. Bone fragments at both TP I and TP II totalled 10 grams. In all probability they were animal bone fragments. Other organism artefacts found were two molar tooth fragments in TP II spit 2 (4 g), located close together.

With the findings of bones, tooth fragments and coal it can be stated that the people, at that time, consumed meat. Animals eaten by Old Balinese were pig, cattle, dogs, fish, and fowls (Archaeological Team of Udayana University 2004; 2005). These animals were not wild, but bred.

\section{Summary}

Findings at Batu Gambir Site were judged to be isolated or related artefacts and ecofacts. Most findings were fragments of earthenware. Types of earthenware were identified by rim fragments, fragments of plates, bowls, basins, jars and lids.

Other artefacts found were Chinese ceramics, which can be identified as to origin date and shape. Findings can be sorted into four groups: plates, bowls, box and jars calculated to be from the Sung, Yuan and Ming Dynasties that flourished between the $10^{\text {th }}$ and $16^{\text {th }}$ century. Artefacts that supported social interaction or commerce were the Chinese coins apparently used as a form of payment.

Ecofacts that suggested other activities were the findings of charcoal, bone, and teeth fragments from animals. The Julah people had a sophisticated coinage system used for commerce outside their community. The Batu Gambir Site was a characteristic "settlement" with its people probably making their living from farming and raising livestock. The evidence of money (coins) however, proves that the 
inhabitants of this settlement were integrated in an encompassing system of exchange and trade.

\section{References}

Archeological Team of Udayana University

2004 Ekskavasi Arkeologi di Situs Pacung, Tejakula Buleleng. Laporan Penelitian. Denpasar: Fakultas Sastra, Universitas Udayana.

2005 Ekskavasi Arkeologi di Situs Sembiran dan Pacung Kecamatan Tejakula Kabupaten Buleleng, Bali. Laporan Penelitian. Denpasar: Fakultas Sastra, Universitas Udayana.

Ardika, I Wayan

1988 Ekskavasi Arkeologi di Situs Pacung, Sembiran dan Julah. Kecamatan Tejakula, Buleleng. Laporan Penelitian. Denpasar: Fakultas Sastra, Universitas Udayana.

1991 Archaeological Research in Northeastern Bali. A Thesis Submitted for the Degree of Doctor of Philosophy at the Australian National University. Canberra: Australian National University.

Brandes, J.L.A.

1889 De koperen platen van Sembiran (Boeleleng, Bali): Oorkonden in het oudJavaansch en het oud-Balineesch. Tijdschrift voor Indische Taal-, Land- en Volkenkunde XXXIII. Batavia: Albrecht \& Rutche: 16-56.

Goris, R.

1954 Prasasti Bali. Lembaga Bahasa dan Budaya. Fakultas Sastra dan Filsafat, Universitas Indonesia. Bandung: Masa Baru.

International Field School of Archaeology

1991 Buku Panduan Keramik. Trowulan: Pusat Penelitian Arkeologi Nasional.

Santoso, Ida Bagus

1965 Prasasti-Prasasti Raja Anak Wungsu di Bali. Denpasar: Fakultas Sastra, Universitas Udayana.

Soejono, R.P.

1962 Preliminary Notes on New Finds of Lower Paleolithic Implements from Indonesia. Asian Perspectives V: 217 - 233.

Sutaba, I Made

1976 Megalitic Tradition in Sembiran North Bali. Aspek-aspek Arkeologi Indonesia, Vol. 4. Jakarta: Pusat Penelitian Arkeologi Nasional.

1980 Prasejarah Bali. Denpasar: Yayasan Purbakala Bali.

Poesponegoro, Marwati Djoened dan Nugroho Notonegoro

1984 Sejarah Nasional Indonesia I. Jakarta: PN Balai Pustaka.

Purbo-Hadiwidjojo, M.M.; H. Samodra and T.C. dan Amin

1998 Peta Geologi Lembar Bali, Nusa Tenggara. Skala 1 : 250.000. Bandung: Pusat Penelitian dan Pengembangan Geologi. 
Purbo-Hadiwidjojo

1971 Peta Hidrogeologi Tindjau Lembar Bali. Skala 1 : 250.000. Bandung: Direktorat.

Tim Jurusan Arkeologi

2005 Laporan Penelitian Ekskavasi Arkeologi di Situs Batu Gambir, Kecamatan Tejakula, Buleleng. Denpasar: Fakultas Sastra, Universitas Udayana. 


\title{
Socio-Political Aspects of Ancient Julah
}

\author{
I Ketut Setiawan
}

\section{Introduction}

This paper deals with Julah's culture based on the evidence of the Sembiran copperplate inscriptions dated between the $10^{\text {th }}$ and $12^{\text {th }}$ century (see HauserSchäublin and the literal transcription and translation into Indonesian this volume).

Julah Village is a village as old as its name. Brandes (1889) and Goris (1954) discovered that the village was already called Julah on the inscriptions kept at the holy places in Sembiran and Julah. These old inscriptions were carved on sheets of copper. The highly sacred inscriptions, the work of men of letters, refer to various events that took place in the past, and can give detailed information about the life of Balinese people at that time.

It is impossible to describe Julah's entire history since there are almost no written sources available. These inscriptions are therefore unique historical documents that cover a period of 200 years. An inscription was a royal edict issued by a king or another authority containing the decisions he made. Some were issued to certify that a piece of land had been allocated or belonged to a village because there was a holy place in that specific area, and that the village had the right to achieve the status of a perdikan (freehold) village.

As a royal certificate, an inscription had a legal and magical religious power. The legal power of an inscription consisted of the king's orders and the conse- 
quences of disobeying them. The inscriptions mention fines to be paid, for example in the form of gold and silver. The magic religious element of such an edict was shown by the process of its implementation. It was determined by a religious ceremony in which praises to the gods were recited, and sapatha (curses) were made on those who violated what was determined by the inscription.

Both the legal and the magic power of an inscription made it authentic and binding (Darmosoetopo 2003). The advantage of such an inscription was that it functioned as a guideline to be consulted in case royal advice was needed. These legal aspects contribute to their value as historical documents.

Considering that an inscription was an official certificate from a king, or another authority in a kingdom, we may regard it as an authentic document reflecting true conditions of life at that time. For this reason, an inscription can be seen as the main source for understanding the rights and obligations of a person, a village, or a holy building (monastery, temple etc.), sometimes including the reasons why such rights and obligations were provided. Various facts can be revealed related to the political, social, economic, and cultural life of a community in the past (Wibowo 1992:63).

\section{The Individual Inscriptions}

In Julah several inscriptions are kept issued by the kings of Old Bali. They have survived more than 1.000 years because they were written on sheets or plates of copper (tamra prasasti) which are generally $30 \mathrm{~cm}$ long and $11 \mathrm{~cm}$ wide. The inscriptions relating to Julah were called by Goris "Sembiran Inscriptions" since all of them were kept in Sembiran in the second half of the $19^{\text {th }}$ century when they were discovered by Dutch scholars.

The individual inscriptions are as follows:

\section{Sembiran Inscription A I, dated 922 AD}

This inscription consists of four pieces written in the Old-Balinese language and characters. On pieces Ib, IIa-b and IIIa-b six lines are carved and on piece IVa only two lines are carved. The inscription starts with the words "yamu pakatahu" ("you shall know"), followed by three royal authorities mentioned. Those are sarbwa, dinganga and manuratang ajna who received orders from the king. The main content of the inscription is that robbers (probably pirates) had destroyed Julah and captured many people. Due to these events, the village was freed from taxes. The village was given the right to keep canoes, boats and ships which had been washed ashore (tawan karang). Taxes were contributed to the holy places existing around the village. In addition, the rights and obligations of the villagers and Julah's boundaries according to the four points of the compass are mentioned. Inhe- 
ritance patterns were also determined by the inscription, especially for childless couples. If a couple had children, two thirds of their wealth was inherited by the son and one third by the daughter. If both spouses had died, all wealth was submitted to the village after deduction of funeral expenses. The king issuing the inscription was King Ugrasena.

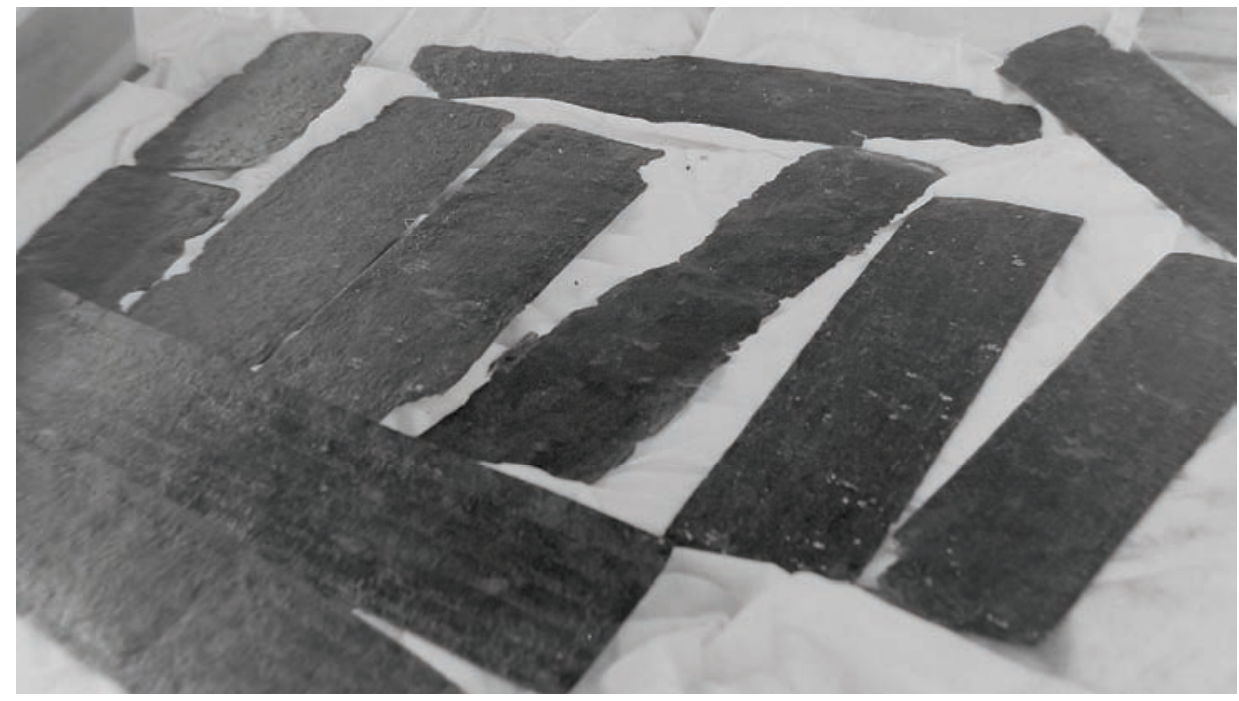

Photo 1: Ten sheets of the copperplate inscriptions still kept in Sembiran. Photo: Jörg Hauser 2003.

\section{Sembiran Inscription A II, dated 975 AD}

This inscription consists of two pieces of copper and is a continuation of the inscription of Sembiran AI.

It starts with the word "punah" ("once again") and was issued in the month of cetra (March), one of the five dark months, at a place called wijayamanggala (Goris 1954: 77). The king issuing it was Sri Janasadhu Warmadewa. The inscription contains the determination of various kinds of taxes and demarcates the firm borders of Julah in all the directions of the compass. If there was a plantation, a public bathing place, a holy place or a monastery that had been damaged, the villagers, supported by Bondalem village, had to repair it. In addition, this inscription contains the rights and obligations of Julah and the statement that if there were robbers who dared to destroy the monastery located at Dharmakuta, all the villagers were obliged to defend it.

At the end of the inscription a number of royal authorities functioning as witnesses during its presentation by the king are also mentioned. Their titles are senapati, samgat, nayakan, caksu, and manuratang ajna. 
Sembiran Inscription A III, dated 1016 AD

This inscription consists of three pieces of copper carved in the Old Balinese language and characters. It was issued by Raja Sri Sang Ajnadewi, a woman who governed Bali and replaced Raja Udayana Warmadewa and his wife Gunapriya Dharmapatni. As the inscription of Sembiran AVII, it starts with the word "punab" and was issued on the sixth day of the bright half of the month asuji (September) on the market day at wijayakranta (Goris 1954:95).

The main content of the inscription is that the people at Julah village informed Raja Sang Ajnadewi that their village had been destroyed again and many people had been killed while the survivors had fled to other villages. Before, Julah had been inhabited by 300 families; afterwards only 50 families were left. Therefore, they asked to be freed from taxes. In the end of the inscription the royal authorities who were present as witnesses are also mentioned. Their titles are senapati (senapati dinganga, senapati tunggalan, senapati kuturan), samgat (samgat juru wadwa, samgat mangireniren, samgat prah, samgat manurang ajna, samgat pituha), caksu (caksu karanapura, caksu karankranta). In addition, the inscription notes some Siwaist and Buddhist priests attending the issuing as well.

\section{Sembiran Inscription A IV, dated 1065 AD}

This inscription consists of six pieces of copper carved in the Old-Javanese language and characters. The main content of the inscription which was issued by Raja Anak Wungsu clarified the rights and obligations of the Julah community which had been determined in the previous inscription. On the other part the inscription mentions a number of the village leaders such as dbikara, juru gusali, banjar, rama kabayan, sabaya and panulisan who met the king and reported various problems to him. Raja Anak Wungsu seemed to lend an ear to his people's complaints. He asked the village authorities to take part in finding solutions to the problems faced by the people in Julah, especially those related to their heavy obligations.

Furthermore, the inscription arranged and determined the social aspects of community life as well. If there was a group of artists such as mask dancers, clowns and traditional music players that came to the village, taxes could be levied. However, regular groups of artists should be distinguished from those who came from the palace.

Some species of domestic animals such as cows, goats, chickens, ducks, buffaloes and pigs were also mentioned on the inscription. If robbers came to Julah, all the people should face them with the weapons they had. At the end of the inscription, magic sanctions to be imposed upon those going against what had been determined on the inscription are listed. In addition, the inscription refers to certain authorities who were present when the inscription was presented to the people at Julah. 


\section{The Kings Who Issued the Edicts}

As the Sembiran inscriptions described above show, they were issued in different periods and by different kings. The inscription A I was written by the king Sri Ugrasena. He governed Bali from 915 to 942 AD. On the evidence of other inscriptions bearing his name, a number of important royal policies can be ascertained. Some of them related to a decrease in the taxes payable by the villagers, because they had not recovered from the damage done by the robbers. King Ugrasena seemed to pay attention to the condition of his people in the villages. This inference can be drawn from the information contained in the inscription of Babahan I, in which the king stated that he had visited Bubunan and Songan. During his visit, he permitted the community to carry out ceremonies for those who had died an unnatural death. Furthermore, closely related to the aspect of religious life, King Ugrasena permitted the people in Parcanigayan to widen the rest house for pilgrims and the sanctuary (temple) Hyang Api that was close by.

In addition to the Sembiran inscription A I and that of Babahan I, King Ugrasena also issued the inscription of Srokadan A, the inscription of Pengotan A I, the inscription of Batunya A I, the inscription of Dausa A I, the inscription of Serai A I, the inscription of Dausa B I and that of Gobleg Pura Batur A. They are all written in the Old Balinese language starting with the word yumu pakatabu ("you shall know"). At the end of the inscriptions the place where they were issued was also mentioned, namely panglapuan Singhamandawa.

In 975 AD, Bali was governed by King Sri Janasadhu Warmadewa. This name is inscribed on Sembiran A II as mentioned above and is the only existing inscription he issued. The inscription stated that the people from Julah who returned from their place of exile were permitted to renew the content of the earlier inscription. Then, what was laid down in the inscription was to be obeyed and was not to be changed any more. It was determined that if there was a temple, a cemetery, a public bathing place or a street that had been damaged, it should be repaired by the people at Julah and Buwundalem (Boudalem) at their own expense. If the monastery at Dharmakuta was attacked the villagers at Julah were requested to go out with weapons to protect it (see above).

The history of Queen Sang Ajnadewi can be explained as follows: she was crowned to replace King Udayana Warmadewa. However, there was no clear relationship between her accession and the king being replaced. In order to obtain clear information, the inscription of Pucangan issued by King Airlangga, the ruler of East Java, needs to be considered. In this inscription it is mentioned that in 1016 AD the Dharmawangsa kingdom in East Java was attacked by King Wurawari probably from the Shailendra Dynasty (Sumatra) resulting in destruction (pralaya). While the wedding ceremony of Airlangga and Putri Dharmawangsa took place the attack was perpetrated at the same time. It is stated that Java Island looked like an ocean of fire and that many people and royal authorities had died. Airlangga, who was 16 years old at that time, was able to save himself by fleeing to 
a forest accompanied by his faithful follower named Narottama (Sumadio 1984:173; Semadi Astra 1997:67).

During the year of pralaya the name of Queen Ajnadewi who governed Bali appears in the historical sources. Regarding this fact it can be assumed that Udayana (Airlangga's father) who apparently was present at the marriage ceremony of his son in East Java was killed, resulting in the throne in Bali being suddenly vacant. To fill his vacancy, the royal family may have appointed a relative named Sang Ajnadewi as Queen of Bali. On the inscription of Sembiran A III (the only inscription issued by this queen), it was stated that Julah was attacked by enemies. Many people died, were captured by the enemy or fled to other villages. Previously, the village had been inhabited by 300 families, out of whom only 50 families survived. The queen therefore lowered certain taxes and other obligations relating to mutual cooperation.

The history of King Anak Wungsu can be explained as follows: Anak Wungsu was King Udayana Warmadewa's youngest son who was enthroned in Bali to replace Marakata Pangkaja, his older brother. From the inscriptions he issued, it can be stated that he governed Bali for a long period: indeed he was the longestlived of the kings in the Old Bali era, reigning for 28 years (1049 - 1077 AD). Not less than 30 inscriptions were issued during his reign. The long period of government and the inscriptions issued can be seen as a sign that King Anak Wungsu governed wisely and that the kingdom was stable.

Some inscriptions give evidence of the fact that King Anak Wungsu was a king who always thought of his people's and the realm's well-being. In addition, this king highly respected welfare, since he was symbolized as the reincarnation of Dewa Dharma (God of Welfare). He always paid attention to the complex of the holy places such as Gua Gajah and Candi Padas at Gunung Kawi, Gianyar Regency. It was probably he who initiated the establishment of these holy places. He may even have promoted the coming into existence of the subak (a traditional farmers' irrigation organization). Subak still exist; their members build weirs used for damming up water flowing from big rivers so that the water can reach the rice fields through specially built channels. They have also been able to build tunnels for proposes of irrigation.

It is interesting that during Anak Wungsu's government, a classification of the community into two groups came into being: one was the catur warna and the other was the group of those who were excluded from catur warna. Catur warna consisted of four social strata, probably associated with a distinct division of labour, similar to the caste system in India. The brabmana took charge of religious ceremonies, ksatria comprising those who were empowered to lead and defend the rulers, wesya comprising those who were empowered to run business and sudra comprising ordinary workers. There also existed slaves. The inscription of Buyan stated that if there were slaves that fled to Buyan, they could not be caught, arrested or beaten. 
There are various reasons why slavery existed. One, at least as far as we know from later times, relates to those who were convicted for crimes and could not pay the fines imposed. They could become the slaves of the king or work for those of whom they were debtors. The masters were permitted to sell their slaves for which they would receive cash or would use the slaves as guarantees for the money owed. It is stated in the inscription that:

\section{"Kunang ya tan aharp sumahura butangnya srahaknanya ikang rarai bulun irika sang pradhana" \\ Meaning: \\ "If they are not able to pay their debts, they have to give a young slave to the person to whom they owe the debts".}

\section{Social Groups and Communities Described}

There seems to be no doubt that the site of Old Julah is identical with current Julah. As a harbour town, Julah was frequently visited by traders coming from different regions, even outside Bali.

In general, the Balinese communities differed according to their location: those that lived in the hinterland and who generally earned a living from agriculture, and the others that resided close to the coast and generally earned a living as fishermen or as traders. The people who lived in the hinterland produced rice abundantly and needed salt and sea fish from the coast. In contrast, the people who lived in the coastal areas needed rice and vegetables from the hinterland; in this way the two groups were interconnected through an exchange of produce. The differences in what they produced promoted trade. The products they traded can be classified into four kinds: food, clothing, general equipment and animals.

The food included onions, garlic, rice, sugar, salt, ginger, areca nut, various kinds of fruit such as mango, coconut, papaya, pine apple, mangosteen and various kinds of fish, both sea fish and fresh water fish. Clothing included cloth, colouring materials, cotton and thread. The general equipment included precious stones, bronze, baskets, tools made of copper, iron, ornamental things, lead and clay crockery. The animals included buffaloes, cows, goats, pigs, ducks, chicken and birds. Half the things mentioned above were transported by horse, cart, and boat and were carried on the shoulders (Jones 1984:56-61).

Based on the information obtained from the inscriptions found at Sembiran, we can conclude that the traders could be divided into two groups. The people who belonged to the first group were members of the Balinese community. Their scope of trading was limited to their own region (local traders) or to a number of villages or towns and was possibly restricted to goods for everyday life such as 
rice, vegetables, fruit and the other needs which did not last long (Raharjo 2002:299).

The people who were classified as foreign traders were foreign citizens who traded up to Bali; some of them came from the Indonesian archipelago, others came from Asia, especially India, China and Cambodia. The exact origins of the traders who came from the Indonesian archipelago were not explicitly mentioned (Sembiran AIV), but in any event they came by boat, ship, and canoe and anchored at Manasa (banyaga sakeng sabrang, jong, bahitra, cumunduk $i$ manasa). Manasa Site played an important role in revealing information related to trade between the $11^{\text {th }}$ and $13^{\text {th }}$ century. This site is mentioned in the inscription of Sawan A I (1023 AD) issued by King Marakala Pangkaja. Manasa, which is located in the northern coast of Bali, used to be an important harbour and attracted many traders, both local and foreign. The inscription of Kintamani E issued by King Eka Jaya Lancana (1122 saka) also mentioned that Manasa; the cotton traders from Kintamani regularly visited Manasa to sell their products.

This shows that trading developed well during that era. This is proved by the fact that there were groups of merchants called wanigrama (male merchants) and wanigrami (female merchants), that lived in the villages. They had leaders called juru wanigrama who looked after their needs.

One of the inscriptions kept in Julah contains the information that trading practices had already developed and that money had already been used as a means of payment. The data in the inscriptions revealed that the currency units used were marked by the abbreviations su (suwarna), ma (masaka) and ku (kupang). In the inscriptions of Old Bali, a market was referred to as pken.

Julah, as a village and a harbour town, had already developed since the $10^{\text {th }}$ century. Several social groups are mentioned in the inscriptions based on, territorial units, professions and the positions and roles in areas of government. The territorial units were referred to as wanua or thani ("village area"). Based on these territorial units, the inhabitants were anak wanua or anak thani meaning "villagers". This term referred to those who resided in a village, who had land possession rights and who could be elected as village leaders.

Among all the villagers, there were a number of people who were considered senior and capable of solving problems faced by the village. They were supposed to represent the villagers in presenting their problems to the authorities. Those who were considered senior in the inscriptions of Julah were called tuha-tuha or karaman (Sumadio 1984:200).

Another type of social group to be established was based on economic life. Among them were farmers. The inscriptions mention sawah, parlak, gaga, kebwan, and buma meaning rice fields, dry fields, rice, and plantations. The farmers grew rice, coconut, taro, onions, garlic, ginger, carrot, areca nut, oranges, soy beans, chilli, bananas, cotton and so on (Sumadio 1984:200). In addition to farming, the 
people also made a living by raising animals such as cows, ducks, goats, pigs, chickens, horses and buffaloes.

Some members of the group also had skills in craftsmanship commonly called undagi. It was mentioned in the inscriptions that they worked as carpenters, bricklayers, house builders and workmen building tunnels and canoes or constructing market halls.

The smiths constituted a particular social group: pande tembaga (coppersmith), pande besi (blacksmith) and pande kangsa (bronzesmith).

Further social groups consisted of artists such as royal artists and folk artists who used to go around the villages. The performers usually received financial rewards for their services, which in the inscriptions were called patulak. However, no information is available concerning the number of performers, the themes performed or the uniforms worn.

The last social group to be mentioned is that of the political elite, that is, those people who played an important role in government; they seemed to come from different social strata.

At village level there was one institution called karaman consisting of the older villagers and the local religious leaders such as sang ma thani and manuratang. They had the function of village head and village secretary. To control the government at village level on behalf of the king, a person was appointed who bore the title of a caksu. Hulu kayu was an authority whose function was controlling forestry and who played an important role in the government. Furthermore, bulu kayu frequently led the village's representatives to visit the king informing him about their needs and worries. There was another position called Sang admak akmitan apigajih whose function was to collect taxes for the king at village level. The religious leaders included the head of the monastery, religious teachers and the priests responsible for the ceremonies at the holy shrines around the village. When needed, karaman could hold a meeting attended by the village leaders, in which important things related to the problems faced by the village were decided.

\section{Religious and Political Aspects}

The archaeological findings show that the settlements of the community spread over the valleys, the mountains and the coastal areas. These regions were so thinly populated that many villages had large areas of forests and rice fields that belonged to the common people. The king and his relatives had particular pieces of land cultivated by his servants. In addition to the community of farmers, there was another community whose members were the traders and the handicraftsmen. Those had the right to reside in a particular area. There were also other small communities whose members worked as craftsmen making clay pans, mats and the like; however they did not live in a separate settlement (Kartodirdjo 1993:35). 
As with the other agricultural societies in Bali, religion played an important role. As a result, a feature of the civilization in Bali was the presence of religious leaders of different denominations such as Siwa priests, Buddha priests, Waisnawa priests and so on. The leading positions were held by the priests at central, regional and village level.

In their capacity as religious leaders at the highest level they were in a powerful position - they had the right to attend audiences with the king in which also political problems were discussed. They also had the right to be present as witnesses when an inscription was granted to the village representatives.

One of the essential characteristics of Bali Kingdoms was that honour should be paid to the royal ancestors in order to maintain the cosmic system. During Old Bali, the honour paid to the king's ancestors was conducted at the same time as when the king was glorified at the temples both Siwa and Buddha. The appointment of priests as higher royal employees was intended to maintain the religious system as part of the power system.

The religious leaders usually lived under the guidance of a high priest in holy places located in freehold territories such as mandala, sima and wihara, for example. They were free from taxes and from the intervention of the king. However, they needed to maintain a good relationship with the palace and were faithful supporters of the kingdom.

Social life at that time was not free from conflict. There apparently were periods when the social norms were frequently broken and many crimes occurred. Such crimes could cause unrest and spread to other social groups, and violate generally acknowledged ethics and morality. Poverty led to hatred and jealousy which finally contributed to immorality. Conflicts could then not be avoided.

The inscriptions found at Sembiran contain the information that there were many social conflicts at Julah. As a town harbour, it attracted traders, both local and foreign. The village was frequently visited by pirates who killed villagers and made many others flee to the other villages to take refuge. According to the inscription of Sembiran A II the king asked the refugees to return to their village to face the enemies who intended to destroy the Dharmakuta monastery. The Sembiran inscription A III, as stated, mentions that only 50 out of 300 families survived an attack by pirates.

As a harbour, Julah received various kinds of taxes and duty. It can be concluded therefore that the living standard of the people living at Julah at that time was quite good. However, since the society was clearly stratified we can assume an inequality in the standard of living as well. These differences certainly led to social jealousy and, hence, to conflict. 


\section{References}

Brandes, J.L.A.

1889 De Koperen Platen van Sembiran (Boeleleng, Bali): Oorkonden in het OudJavaansch en het Oud-Balineesch. Tijdschrift voor Indische Taal-, Land- en Volkenkunde XXXIII. Batavia: Albrecht \& Rutche: 16-56.

Darmosoetopo, Riboet

2003 Sima dan Bangunan Suci Keagamaan di Jawa Abad IX - X. Yogyakarta: Prana Pena.

Goris, R.

1954 Prasasti Bali. Lembaga Bahasa dan Budaya. Fakultas Sastra dan Filsafat, Universitas Indonesia. Bandung: Masa Baru.

Jones, A. and M. Barret

1984 Early Tenth Century Java from the Inscriptions: a Study of Economic, Social and Administrative Conditions in the First Quarter of the Century. Verhandelingen van het Koninklijk Instituut voor Taal-, Land-, en Volkenkunde, Vol. 107.

Dordrecht: Foris Publications.

Kartodirdjo, Sartono

1993 Pendekatan Ilmu Sosial dalam Metodologi Sejarah. Jakarta: Gramedia, Pustaka Utama.

Rahardjo Supratikno

2002 Peradaban Jawa: Pranata Politik, Agama dan Ekonomi Jawa Kuna. Jakarta: Komunitas Bambu.

Semadi Astra, I Gede

1997 Birokrasi Pemerintahan Bali Kuno Abad XII-XIII: Kajian Epigrafis. Yogyakarta: Universitas Gajah Mada.

Sumadio, Bambang et al.

1984 Sejarah Nasional Indonesia, Vol. II. Jakarta: Depdikbud.

Wibowo, A.S.

1992 Prasasti Alassantan. Majalah Arkeologi 4. Jakarta: Universitas Indonesia. 

Appendix 



\section{Sembiran Inscriptions}

\section{Introduction}

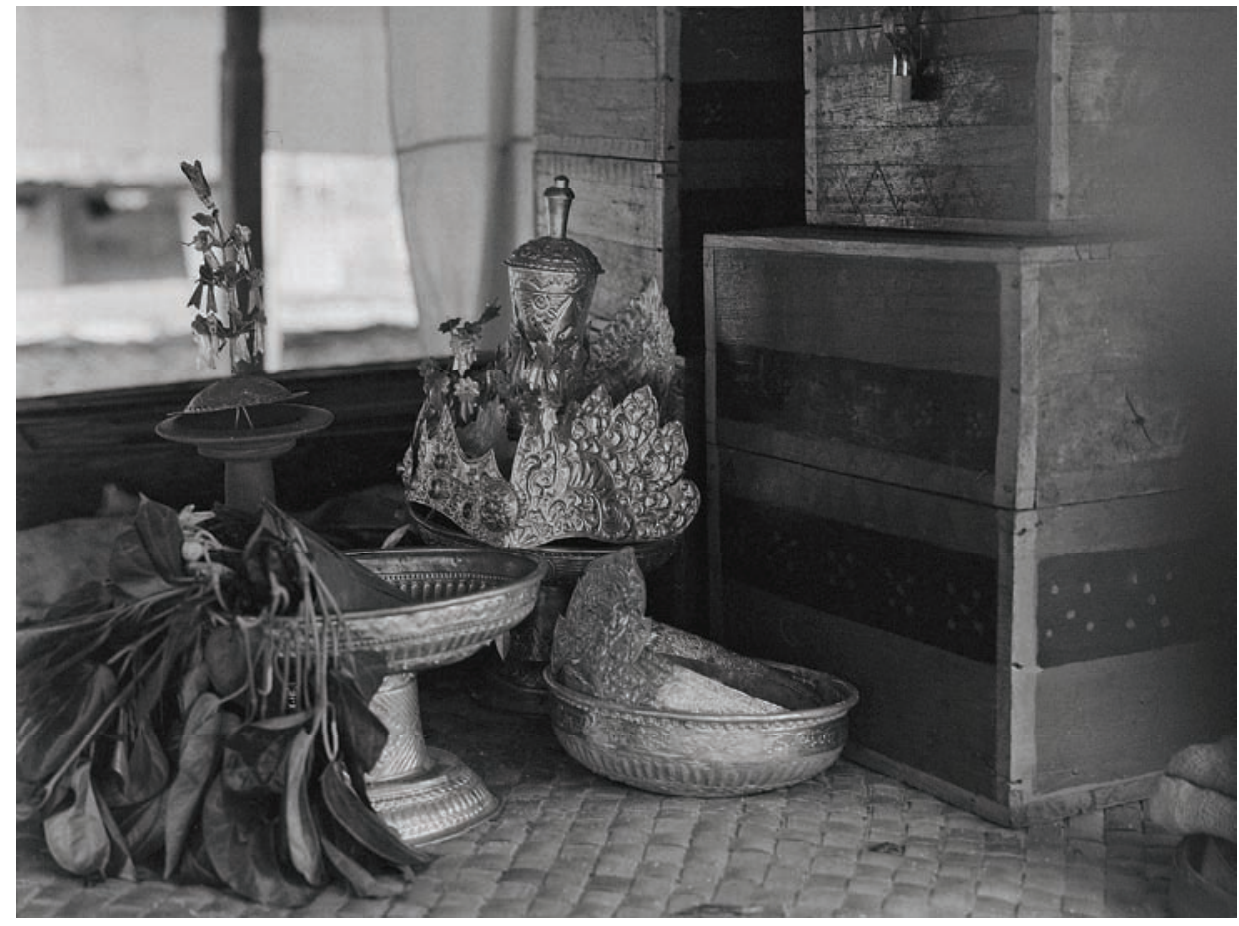

Photo 1: A royal crown is venerated as a sacred heirloom in Julah's Village Temple at one of the festivals commemorating this gift of a king (probably many centuries ago) for Julah's loyalty towards him.

Photo: Jörg Hauser 2003.

The following section contains the transcription of the so-called "Sembiran inscriptions". These indigenous sources are all dated, between AD 951 and 1181, thus covering a period of more than 200 years. They are the earliest documents for this area and therefore extremely valuable since they all refer to the village of Julah, the main focus of this book. These copperplate inscriptions were classified by Goris who carried out the first tentative translation (1954). Goris' classification 
runs as follows: "no. 104 Sembiran A I" dated saka 844 (AD 922)1 , "no. 201 Sembiran B", dated saka 873 (AD 951), "no. 209 Sembiran A II", dated saka 897 (AD 975), "no. 351 Sembiran A III", dated saka 938 (AD 1016), "no. 409 Sembiran A IV" dated saka 987 (AD 1065), "no. 621 Sembiran C” dated saka 1103 (AD 1181).

Many of the articles in this book refer to the contents of these inscriptions. We therefore decided to publish them in this volume in the way they were accessible to us.

The texts were translated by I Wayan Ardika and Ni Luh Sutjiati Beratha into Bahasa Indonesia ${ }^{2}$ (1996 und 1998) and "Sembiran C", into English by I Wayan Ardika (1991). ${ }^{3}$

The principle of transcription and translation runs as follows:

1. Line: transcription ${ }^{4}$

2. Line: literal translation

3. Line: colloquial translation

\section{References}

Ardika, I Wayan

1991 Archaeological Research in Northeastern Bali. A Thesis Submitted for the Degree of Doctor of Philosophy at the Australian National University. Canberra: Australian National University.

Ardika, I Wayan and Ni Luh Sutjiati Beratha

1996 Perajin pada Masa Bali Kuno Abad IX-Xl, Vol. 1. Denpasar: Fakultas Sastra Universitas Udayana.

Ardika, I Wayan and Ni Luh Sutjiati Beratha

1998 Perajin pada Masa Bali Kuno Abad IX-Xl, Vol. 2. Denpasar: Fakultas Sastra Universitas Udayana.

Goris, R.

1954 Prasasti Bali. Lembaga Bahasa dan Budaya. Fakultas Sastra dan Filsafat, Universitas Indonesia. Bandung: Masa Baru.

\footnotetext{
${ }^{1}$ The saka year is of Indian origin. The date saka 844 is equivalent to AD 922; thus there is a difference of 78 year between the two calendars.

2 Abbreviations: Dm: Demonstratif; Hon: Honorefik; Jbt: Jabatan; KG: Kata ganti; Konj: Kunjungsi; Neg: Negator/penanda negatif; Nm: Nama orang; NmB: Nama bulan; NmT: Nama tempat; PBL: Pembilang; Prep: Preposisi; PTC: Partikel.

${ }_{3}^{3}$ Abbreviations: cr: currency; ftn: functionary; hnr: honorific; ms: volume measurement; pn: proper name; pro: pronoun.

${ }^{4}$ From a linguistic point of view the diacritics used in the following transcriptions do not offer a comprehensive application. However, in order to provide interested scholars with access to these otherwise unpublished texts, we decided to publish them without further linguistic expertise.
} 


\section{No. 104 Sembiran A I}

Ib.* 1. Yumu pakatahu sarbwa, dinganga kumpi gowinda, mañuratang Kamu harus tahu Jbt, Jbt Nm Jbt

Kamu harus tahu bahwa Sarbwa, Dinganga adalah Kumpi Gowinda, Juru Tulis

äjña astra, pandyan, yajña, ada pnah serpasar, kumpi ba (bugya)n

$\mathrm{Nm}, \mathrm{Nm}, \mathrm{Nm}$, ada pernah Jbt, Nm

Astra, Pandyan, dan Yajna, Pejabat Ser Pasar adalah Kumpi Bahugyan

2. me anak banwa di julah makeahakuta, dhikara kriddhi panundun pu crì, dan orang desa Prep NmT dalam perbentengan, Jbt Nm Jbt Nm dan penduduk desa Julah dalam wilayah perbentengan dengan Dhikara adalah Kridhi,

Panundun adalah Pu Sri,

pratikāya prajña, turut anak banwa, karaksayaña, padma, ki (rata)

Jbt Nm, serta orang desa, Jbt KG3, Nm, Nm

Pratikaya Prajna, beserta penduduk desa (Julah), Keraksayannya adalah Padma, Kirata,

3. crī, pruk, sumambah aku midhih pamasamahyan kutaña, me banwaña

$\mathrm{Nm}, \mathrm{Nm}$, menyembah KG1 minta pemeliharaan benteng KG3, dan desa

Sri, dan Pruk menyembah saya, (mereka) memohon pemeliharaan? bentengnya dan

aksina paraspara känakeañna, lägi tyawan bunin, twa hetu

terlihat semua penduduk KG3, dahulu, tawan musuh, Dm sebab

dijumpai penduduk desa yang dahulu ditawan musuh. Oleh sebab itu

* Side one (Ia) was not inscribed. 
4. syurubku ya, lipetangen anak parumahan di kutaña, marang santänan perintahku KG1 KG3, kembali orang tinggal Prep benteng, semua keturunan perintahku kepada mereka agar kembali bertempat tinggal di daerah perbentengan dengan semua keturunannya

marumah ditu, simayangña hangga air lutung karuh, hangga duri (lwa) tinggal di sana, perdikan KG3, batas NmT barat, batas $\mathrm{Nm} T$ yang tinggal di sana. Batas wilayah perdikannya adalah Air Lutung batasanya di sebelah barat, Duri Lwarlwar batasnya

5. rhwar kalod, hangga air byang kangin, hanggämpuban kadya, tani kabakaten NmT kelod?, batas NmT timur, batas laut kaja, Neg dikenai di kelod. Air Hyang batasnya di timur, dan laut batasnya di kaja. (Penduduk) tidak dikenakan

mamatek papan, matkap bantilan lañcang, parahu

membuat? papan, membuat wantilan/paviliun sampan perahu kewajiban membuat papan, memebuat wantilan, sampan, perahu

6. mangrapuh mangharañi, manutu, tikasan, di tambang di buru, tapahaji, membuat kampur, membuat arang, menumbuk padi, pajak, Prep tali, Prep Nm'T, NmT membuat kampur, membuat arang, menumbuk padi, pajak tali/tambang? perburuan

Tapahaji

tani pamayam pamli lañcang, pa, pawaruga, me anada caksu

Neg pembayaran pembelian sampan, ...? pajak, dan ada Jbt tidak membayar pajak pembelian sampan, ...? dan pajak pawaruga. Bila ada Caksu

IIa. 1. mamaren ka ditu, tani pasaputyan ya, twa kabakatyanña, wilang tandaga 20 datang ke sana, Neg pakaian KG3, Dm dikenakan, pajak 20 tandaga datang ke sana, (penduduk) tidak harus berpakaian adat tertentu mereka dikenakan pajak Wilang 20 tandaga

tarub mā 12 blindarah (mā 6 sambar karundung 2 tkapanña krtyampung pi 4) pajak 12 masaka pajak 6 masaka pajak 2 karundung ? pajak ? 4 piling Tarub 12 masaka, Blindarah 6 masaka, Sambar 2 karundung, pajak Krtyampung 4 
2. braskaru 3 mulyan palbur mā 1 pi 2 di bakarundung, panali mā 1 pi 2

beras 3 tempurung mengembalikan pajak 1 masaka 2 paling Prep karundung, pajak 1 masaka 2 piling beras 3 tempurung kelapa, mengembalikan Palbur 1 masaka 2 piling setiap Karundung, pajak Tali 1 masaka 2 piling.

tani kadan parchalaña, pamli sang ratu di māgha mā 1 di

Neg ada pajak?, $\quad$ pembelian Hon Prep NmB 1 masaka Prep

Tidak dikenai Parchalana, persembahan untuk Sang Ratu pada bulan Magha 1 masaka,

3. mahānawami, mā 1 pamlin nāyakea di mägha mà 1 di mahānawami mā 1

tanggal 9, 1 masaka pembelian Jbt Prep NmB 1 masaka tanggal 91 masaka pada tanggal 9, 1 masaka, persembahan untuk Nayaka pada bulan Magha adalah

1 masaka pada tanggal 91 masaka,

pamli bhanda mäcaka 4 talikur nāyaka mā 1 arghayangña ana kapas

pembelian barang 4 masaka talikur? Jbt 1 masaka hargaKG3, ada kapas

pembelian barang 4 masaka, talikur? untuk Nayaka 1 masaka harganya. Jika ada kapas

4. ya t üla 2 bnang guñja 2 bartak guñja 20 Inga watu guñja 20 di bakupang

KG3 2 tula benang 2gunja kacang hijau 20 gunja gula batu 20 Prep kupang

2 tula, benang 2 gunja, kacang hijau 20 gunja, gula batu 20 gunja, satu kupang

di guñjan panghumwan, tani blinyan bras Ingis cabya, tingkir.

Prep gunja Jbt?, Neg beli beras minyak cabai, tingkir.

setiap gunja Panghurwan. Tidak membeli beras, minyak, cabai, dan tingkir.

5. anäda pamli, pamahenda bulu sambah jalanangña, tani blinyan ryyaryya

ada pembelian, penjualan Jbt jalan, Neg beli seperti dahulu

Jika ada pembelian dan penjualan Hulu Sambah yang bertindak, yang dahulunya tidak

(dikenai pajak?) pembelian.

pangatawanagña di mãgha kambing rukud 1 hartak raga 1 be

kewajiban? KG3 Prep NmB kambing 1 ekor kacang hijau 1 raga ikan.

Kewajibannya pada bulan Magha adalah (menyerahkan) seekor kambing, 1 raga kacang

hijau, ikan kering

6. sudang rimpi 1 (bwatangña) di nāyaka, angken mägha, hatmuang hatmuang

kering 1 rimpi ? bawa Prep Jbt, setiap $\mathrm{NmB}$, setiap tahun.

1 rimpi (tempat ikan) yang dibawa kepada Nayaka setiap bulan Magha, setiap tahun. 
tarhman katih 10 tajuk papan lambar 1 kulit lambar 1 tani dudukyan

? 10 batang batang papan 1 lembar kulit 1 lembar Neg pungut

Tarhman 10 batang, papan 1 lembar, kulit 1 lembar, tidak dipunguti (pajak)

IIb. 1. sampi (besara me kambing), lagan leran ma 1 lagan samung ku 1 teher

sapi bagal dan kambing, pajak ? jalan 1 masaka sabungan 1 kupang kemudian

sapi, bagal dan kambing, pajak jalan 1 masaka, pajak sabungan 1 kupang dan

tani pamyutan di nāyakaña, tubañjawa ku 1 tani paparcaksu.

Neg ribut Prep Jbt, Jbt 1 kupang NegJbt.

tidak ribut kepada pemimpinnya, pajak untuk Tuhanjawa 1 kupang, tidak kena pajak?

Paparcaksu

2. han, di upahan tlung mata di hakupang, tani kadan paptangña me tani kadan patalina

? Prep upah 3 mata Prep Kupang Neg kena paptang dan Neg kena patali KG3

...? diberikan upah 3 mata untuk setiap kupang, tidak dikenakan pajak paptang dan

tidak kena pajak Patali.

tani paparcaksuban, anäda samaña babanwa

Neg Jbt jika ada sesamanya satu desa

Tidak dikenakan pajak Paparcaksu. Jika ada sesamanya di satu desa

3. marpunya me mamatampihang punya patpat lalima sumeruña, mäs ku 2

donasi dan lipat donasi empat lima bangunan suci emas kupang 2

berdonasi dan donasi yang berlipat empat lima untuk bangunan suci meru ? 2 kupang

emas

tmwa nāyaka ya pañuligaran, banwa ku 2 tambarpun randa mā3.

pemasukan Jbt KG3 tukang permata desa kupang 2 tambar (upacara) Hon Nm masaka 3

pemasukan untuk Nayaka, tukang permata desa 2 kupang, untuk pajak (upacara) Randa

3 masaka

4. marang kiñakaña alihenña, tambar parladug mā 2 parmasan pamukul

semua? dicari KG3 barang? masaka 2 tukang emas tukang pukul.

semua? dicarinya, pajak barang Parladug 2 masaka, pajak tukang emas dan tukang

pukul gamelan

ma1 pi2 turut saruganña, me sarb, sangkha, tani kadan

masaka 1 piling 2 bersama bungkus KG3 dan rebab, sungu, Neg kena.

1 masaka 2 piling beserta pembungkusnya. Rebab dan sungu tidak dikenakan 
5. parcaksuña, pabharu, tani krangayan, me yanada samaña habanwa pajak pajak Neg suami-istri dan jika ada sesama KG3 satu desa pajak Parcaksu dan Pabharu. Tidak dikenakan pajak suami-istri ? Jika ada sesamanya yang berasal dari satu desa

binicaruditu, mara ngalah pamayarn mās mā 2 tmwan bulu sambah ma.

berbicara di sana, baru kalah pembayaran emas masaka 2 pemasukan Jbt masaka bersengketa di sana, yang kalah harus membayar 2 masaka emas yang merupakan pemasukan Hulu Sambah

6. 1 caksu pi 2 banwa pi 4 ana uparata twanak marumah ditu angsa, 1 pajak piling 2 desa piling 4 jika ada orang meninggal Dm tinggal di sana reinkarnasi 1 masaka, pajak Caksu 2 piling, pajak desa 4 piling. Bila ada orang meninggal yang tinggal di sana, apabila lahir kembali

buruktanahña ma 4 di hadiri, mnvatangña di hulun sambah pajak masaka 4 Prep orang dibawa KG3 Prep Jbt dikenakan pajak Buruktanah (kuburan) 4 masaka untuk setiap orang, dipersembahkan kepada Hulu Sambah

(bulu sambah katakwan di)

Jbt diketahui Prep

Hulu Sambah diketahui

IIIa. 1. ya jhang tmwan bulu sambah mā 1 caksupi 4, wanwapi4 KG3 semua pendapatan Jbt 1 masaka Jbt 4 piling desa 4 piling oleh mereka semua. Pendapatan Hulu Sambah 1 masaka, Caksu 4 piling, desa 4 piling.

ana krangan mawalu ya subunan $<n a>$ tanggungan ulibangan

Ada suami-istri yang meninggal KG3 junjung dan pikul kembalikan Jika ada suami-istri meninggal maka ketentuan mengenai aturan pengembalian hartanya dll. menurut ketentuan suhunan tanggungan

bumatur drbyaña prakāra,

mengatur milik dll.

2. maruhani dwang bhägi babini habhägi haturangña, tani parangsan, laki-laki dua bagian wanita satu bagian aturan KG3, Neg pajak?

Bila si suami meninggal maka dua bagian diserahkan, bila si istri meninggal sebagian saja diahaturkan dan tidak dikenai pajak Parangsang? 
ana krängan ampung ya,

anak banwa

ada suami istri tidak punya keturunan keduannya meninggal KG3, penduduk desa

Bila ada suami-istri yang tidak punya keturunan meninggal dunia maka penduduk desa

tkpyan ya mulyan mā4 alapañamarhantu

bertindak KG3, kembali 4 masaka diambil upacara

yang bertindak dengan mengambil 4 masaka untuk biaya upacara kematiannya.

3. ya, sesan yalap marhantu ya, mas pirak kangsa, bhajana tambra bhäjana,

KG3, sisa diambil upcara KG3, mas perak, perunggu, bejana, tembaga bejana

Sisa dari yang diambil untuk biaya, upacara kematiannya antara lain mas perak, bejana

perunggu, bejana tembaga

bulun, rbwang, karambo, sampi, buma, parlak,

hamba pengikut, kerbau, sapi, sawah, ladang

hamba, pengikut, kerbau, sapi, sawah, ladang

4. padang, mmal, bwatangña di nāyaka, anāda cheda mati, tyarah bunin ya tani

padang rumput, kebun dibawa Prep Jbt, ada cedera mati, ditawan musuh KG3 Neg

padang rumput, dan kebun agar dibawa/diserahkan kepada Nayaka. Bila ada yang

cedera, meninggal atau ditawan musuh mereka tidak

patarubyan ya, tani pabliyan darabña tani parangsan,

pajak KG3, Neg pembeli darah, Neg pajak

dikenakan pajak Tarub tidak kena pajak pembelian darah, pajak Parangsang

5. tani karangyan, baluña katabwan di ya jhäng, tathäpi yanäda kalulandang

Neg suami-istri, janda diketahui Prep KG3 semua, tetapi ada budak/hamba Hon

tidak dikenai pajak Krangan? Hal itu agar diketahui oleh semua janda /duda. Tetapi bila ada yang menjadi kepala budak

markalula, musirang ditu, tani kasiddhan bulukaynña, pangulapen

berhamba, mengungsi di sana, Neg dapat Jbt KG3, silau?

mempunyai hamba, mengungsi di sana, dan tidak diketahui oleh Hulukayunya.

6. pangustaustan ditu, pammiten me ya di banwa, katkanña tinahan buluñ̃a,

....? di sana, pengembalian dan KG3 Prep desa, termasuk ditahan hamba KG3

Pangustaustan? di sana, agar dikembalikan ke desa, termasuk hambanya ditahan.

ana ñak, ya bayarn butanña, hamulaña

ada ingin, KG3 membayar hutang KG3 semula KG3

Bila ada yang ingin membayar hutangnya hanya induknya 
IIIb. 1 bayarnña, tani kadugan, me twanak banwa di julah tani pabunyangen bayar KG3. Neg bunga? dan penduduk desa Prep. NmT Neg sembunyi yang dibayar, tidak dikenai kadugan (bunga ?). Penduduk desa Julah agar tidak menyembunyikan

kalulananak, tubun surubanñ mamrih pakurasan, patrakasihan,

budak anak, tetapi disuruh meminta ......? Surat belas kasihan? anak budak, tetapi disuruh meminta pakurasan, surat belas kasihan

2. pasamayan, pamubakyan, sakramān majengan di kuta, ya patkapangña, persamaan, pajak permulaan, satu karaman masuk di benteng, KG3 ketentuan KG3 agar disamakan (dengan penduduk lain), pajak permulaan sebagai anggota karaman di daerah perbentengan. Itulah ketentuannya,

yanada twānak palamswan marbuma, mangrawi ditu, pamayarn.

bila ada penduduk luar bersawah, beristri di sana, pembayaran

bila ada penduduk dari luar desa (Julah) mengerjakan sawah, beristri di sana agar mereka membayar

3. pangrama mā 1 di hadiri, me yanäda taban karang ditu, parabu, lañcang jukung pungutan 1 masaka Prep diri, dan bila ada tawan karang di sana, perahu, sampan,

pajak desa 1 masaka setiap orang. Dan bila ada tawan karang (pajak penawan) jukung. di sana terhadap perahu, sampan, jukung

talaka, anak banwa katahwan di ya, kajadyan wrddhi kinwaña sejenis jukung/sampan, penduduk desa diketahui Prep KG3, dijadikan kemakmuran ditawan KG3

sejenis jukung/sampan, bila diketahui oleh penduduk desa maka hasil tawanannya dijadikan wrddhi (untuk kemakmuran penduduk)

4. makatahu aku, pyanekangña bhaktiña, di bhatära punta byang, cincin singhäla tahu KG1, dinaikan KG3 bakti KG3, Prep NM cincin NmT supaya aku diberitahu (penduduk) agar mempersembahkan baktinya kepada Bhatara Punta Hyang yakni sebentuk cincin Singhala.

bantuk 1 tanda haji, bharaña mä 4 ya kramäña tani kasiddhan

1 bentuk tanda raja, berat KG3 4 masaka ketentuan Neg dapat dengan ciri/tanda dari Raja, beratnya 4 masaka, (perintah raja) agar tidak dapat 
5. twa nājake leran, tuhañjawa, tuhañcadar me anak dyängca, krängan

Dm Jbt Jbt, Jbt, dan keturunan, suami istri yang tidak punya keturunan (diganggu) oleh Nayaka Leran, Tuhan Jawa, Tuhan Cadar dan mereka yang punya

keturunan ataupun tidak punya keturunan

turut sabāyaña, makasupratibaddha, sanggarugyan ya,

serta Jbt, agar kokoh, ragu KG3,

serta sahayanya, agar tetap kokoh dan (tidak) meragukan.

6. ajñan, sang ratu gr i ugrasena, syubunang näyakan makarun kulang-kaling,

perintah $\mathrm{Nm}$, junjung Jbt $\mathrm{Nm}$

perintah Sang Ratu Ugrasena, jungjungan Nayakan Makurun yang bernama Kulang-Kaling.

turun di panglapwan di singhamandawa, di wulan mägha çukla pañcami

turun Prep persidangan Prep NmT, Prep bulan NmB paro terang lima

ditetapkan di persidangan di Singhamandawa pada bulan Magha tanggal lima bulan

separoh terang,

IVa. 1. (rggas) pasar bwajayamanggala, di çaka 844 kilagiña di potthagin äjñā //O//.

ketika pasar NmT, Prep saka 844 saat Prep ditetetapkan perintah

ketika hari pasaran di Bwijayamanggala pada tahun saka 844 saat ditetapkan perintah itu. 


\section{No. 201 Sembiran B}

Ia. 1. Çaka 873 bulan posa krsna dwitiya rggas pasar wmijayakranta saka 873 bulan $\mathrm{NmB}$ paroh gelah kedua ketika pasar NmT Pada tahun saka 873 bulan Posa tanggal dua bulan separoh gelap, pada hari pasaran

di Wwijayakranta

tatkeala kyadandha pasang katayandha patra

tatkala Jbt $\mathrm{Nm} \mathrm{Jbt} \mathrm{Nm}$

tatkala Kyadandha Pasang dan Kyadandha Patra

2. tinin banigrama di julah masang kawratan padang* banwwa di julah ...? pedagang Prep NmT merasa berat padang* rumput desa Prep NmT ...? para pedagang di Julah merasa keberatan berkenaan dengan padang rumput desa

blah padapada ñapa sira yan, bubur dangin padang

mangga

bagi sama berkenaan beliau jika, NmT timur padang rumput ke arah jika dibagi sama oleh Beliau (Raja), bubur di sebelah timur daerah padang rumput menuju ke arah

3. lod parkapasan titi darubpadang para me tri hena hamaña kelod kebun kapas jembatan kayu barat padang rumput pergi dan ...? ...? ...? kelod perkebunan kapas, jembatan kayu di sebelah barat padang rumput, pergi dan ...?

\footnotetext{
* Padang is usually translated as 'rumput'; however one has to consider the fact that a belt of forest that formerly surrounded the village of Sembiran was called padang, meaning 'forest' (Hauser-Schäublin).
} 
lengget, rasa truk gnarpapa ni grama ni julah pratida

penis? rasa..? tempat papa Prep suami-istri Prep NmT...?

penis? rasa....para keluarga/suami-istri di Julah...?

4. pat babinin panigrama [G: banigrama?] di julah syanggarudin tri me henaña lenget,

istri saudagar Prep $\mathrm{NmT}$ ragu...? dan penis

istri para saudagar di Julah merasa ragu ... penis?

rasa trukgnar papa ni grama di julah

rasa...? tempat papa Prep suami istri Prep NmT

rasa ... suami-istri di jula

5. di padang di banwwa di julab ba pe bapaña manuduh lod

Prep padang rumput Prep desa Prep NmT bapak bapakKG3 arah kelod di daerah padang rumput di desa Julah. Bapak-bapaknya menuju ke kelod

parkapasa winigraman i julah parana

kebun kapas pedagang Prep NmT semua

ke kebun kapas para pedagang di Julah dan para

Ib. 1. senapati di pelajungan, bekas sumraha siddha ni parumahandha

Jbt Prep NmT, .....? serah dapat Prep perumahanHon

Senapati di Pelajungan, dapat menyerahkan di perumahannya?

matuturin dha senapati di sadatan, drbyaña

menasehati Hon Jbt Prep NmT, Prep milikKG3

menasehati beliau Senapati di Sadatan yang menjadi miliknya

2. binuni, samah ya ta mayangan di lapu kinnuandha senapati

jamu ?, lengkap KG3 Dm bunga Prep lapor...? Jbt

dihormati ? dengan bunga yang lengkap di laporkan kepada yang terhormat

Senapati?

jadi byayarin sang grama bapa winigrama

menjadi bayar Hon suami-istri bapak pedagang

yang dibayar oleh para suami-istri, bapak pedagang

3. nira pachaksuda nugrahan asyateja me anak wanuandha jadi lapu, beliau Jbt sembahan Nm dan penduduk desa Hon jadi lapor? beliau para Caksu menganugrahkan kepada Asyateja dan penduduk desa yang melapor 
kadabulu aman ya di

ke hulu? KG3 Prep

ke hulu kepada

4. pratikayandha naktañjakan, makanna masamah ya

bakti ingettan

Jbt Hon ? ? memelihara KG3 bakti ingat

Pratikayanya... agar memelihara ingat bakti

ulih senapati sadar taña kinuandha

oleh Jbt ? ? ?

kepada Senapati...?

5. pratikayandha naktañjakan makannama iningettingeta yan

Jbt Hon ? ? inget jika

Pratikayanya... agar memelihara ingat bakti

ulih da sang sanapati, me da pratikayandha naktañjakan

oleh Hon Jbt dan Hon Jbt Hon ?

kepada Sang Senapati, dan Pratikaya...?

II. 1. maknna matanaman tan......umanangan di sang ratu

? ? Neg memikirkan? Prep Hon raja

tidak....memikirkan kepada Raja (Sang Ratu)

Kinuanda (senapati).........

? Jbt

...Senapati....

2. pratikayan, da nakkañjakan makanna mayunemann di sang ratu

Jbt Hon ? ? ? Prep Hon raja

Pratikaya...? kepada Raja

jadi kyadan pya sang ratu nata mabli tra

jadi nama ? Hon raja

yang dinamakan oleh Raja...

3. mahenna hamaña lengget rasa truk gnar pabalā grama di julah

? ? KG3 rasa? tempat kekuatan penduduk yang kawin Prep NmT

...tempat kekuatan penduduk Julah yang sudah kawin? 
sumanggarugin padang da banwa di julah blah

meragukan Nm Hon desa Prep NmT pecah

meragukan daerah padang rumput di desa Julah yang dibagi

4. padapada ñapa sira yan pirababya, dapat babinin banigraman i julah semua menyapa KG3 jika seberapa banyak dapat wanita saudagar Hon NmT menjadi sama oleh Beliau, seberapa banyak istri saudagar di Julah mendapat bagian

nabiri suratjayapatra

KG3 memberi surat tanda kemenangan

mereka diberi surat tanda kemenangan

5. paraksayañ̃a di pannahña manawa gunadosaña kilagiña di samohan

prasasti KG3 Prep panah KG3 manusia salah benarnya dikukuhkan di sidang

berupa prasasti, prihal salah benar mereka yang telah ditetapkan dalam persidangan

da senapati di panglapuan...

Hon Jbt Prep Nm'T

oleh Senapati di tempat persidangan

6. ...makasupratibaddha dasatanta tuha tira. ... banwa nayakan, makarun, ida kumpi tuba

tetap kukuh ? Hon $\mathrm{Nm}$ desa Jbt Hon Hon Hon

agar tetap kukuh (ketetapan Sang Ratu) ...Tuha Tira...desa, Nayakan Makarun adalah

Ida Kumpi Tuha,

III. 1. ida mañuratang äjña tuha nandhan tuha kesada, tuha pullang,

Hon Jbt perintah Hon Nm Hon Nm Hon Nm

Juru Tulis Raja adalah Tuha Nandha, Tuha Kesada dan Tuha Pullang,

da di karwa di panglapuan di brsabha tuba

Hon Prep Jbt? Prep tempat persidangan Prep NmT Hon

Beliau Dikara di tempat persidangan di Brsabha adalah Tuha

2. harah da dikara di malapu, hadi pañcakala tuba gunanta da dikara

Nm Hon Jbt Prep persidangan? Prep? NmT Hon Nm Hon Jbt

Harah, beliau Dikara di persidangan di Pancakala adalah Tuha Gunanta, beliau

Dikara

dipanglapuan di baranasi, tuha dara

Prep pesidangan di NmT Hon Nm

di persidangan di Baranasi adalah Tuha Dara, 
3. bapa dikara di panglapuan da bapa kubasa dikara di pa(ng) lapuan

Hon Jbt Prep persidangan Hon Nm Jbt Prep persidangan

Bapak Dikara di persidangan adalah Bapak Kuhasa, Dikara di Persidangan

di tira tuba saddhana da dikara di panglapuan ni surib

Prep Nm Hon Nm Hon Jbt Prep Persidangan Prep?

di Tira adalah Tuha Saddhana, Dikara di persidangan di Surih

4. lamata tuya lampur ida manundun dikarana wijayapura

Nmt Hon? Nm Hon Jbt Jbt NmT

Lamata adalah Tuha Lampur. Beliau Manundun Dikarana di Wijayapura

mwang tarub karung mā 4, patimur mā 3 mwang

dan bertaruh babi jantan masaka 4 ? masaka 3 dan

dan pertaruhan untuk pejantan babi diberikan 4 masaka, Patimur 3 masaka

5. tanin julah, kutur, tukad mamurpur, poh talur, tering wor, batu kamodi,

desa NmT NmT sungai NmT NmT NmT NmT

dan batas-batas desa Julah adalah Kutur, Tukad Mamurpur, Poh Talur, Tering Wor

Batu Kamodi

lijong, baringin, (air pubun),

NmT NmT Nm'T

Lijong, Baringin, Air Puhun

6. air balatuk, air runusan, kutur, air tampiken, pob bacang, air bepu

$\mathrm{Nm} T \mathrm{NmT} \quad \mathrm{NmT} \mathrm{Nm}$ T NmT NmT

sungai Balatuk, sungai Runusan, Kutur, sungai Tampiken, Poh Bacang, sungai

Hepu

beru, airpoh tanduk

Beru, Nm'T

Beru, sungai Poh Tanduk

7. balimbing, rnek, bakar, candi, ikang tanin Julah ...han nika... kabeh $\mathrm{Nm}$ T rawa NmT bangunan suci itulah desa NmT ? Dm seluruh

Balimbing, rawa-rawa, Bakah, dan candi. Itulah seluruh wilayah desa Julah. 
No. 209 Sembiran A II

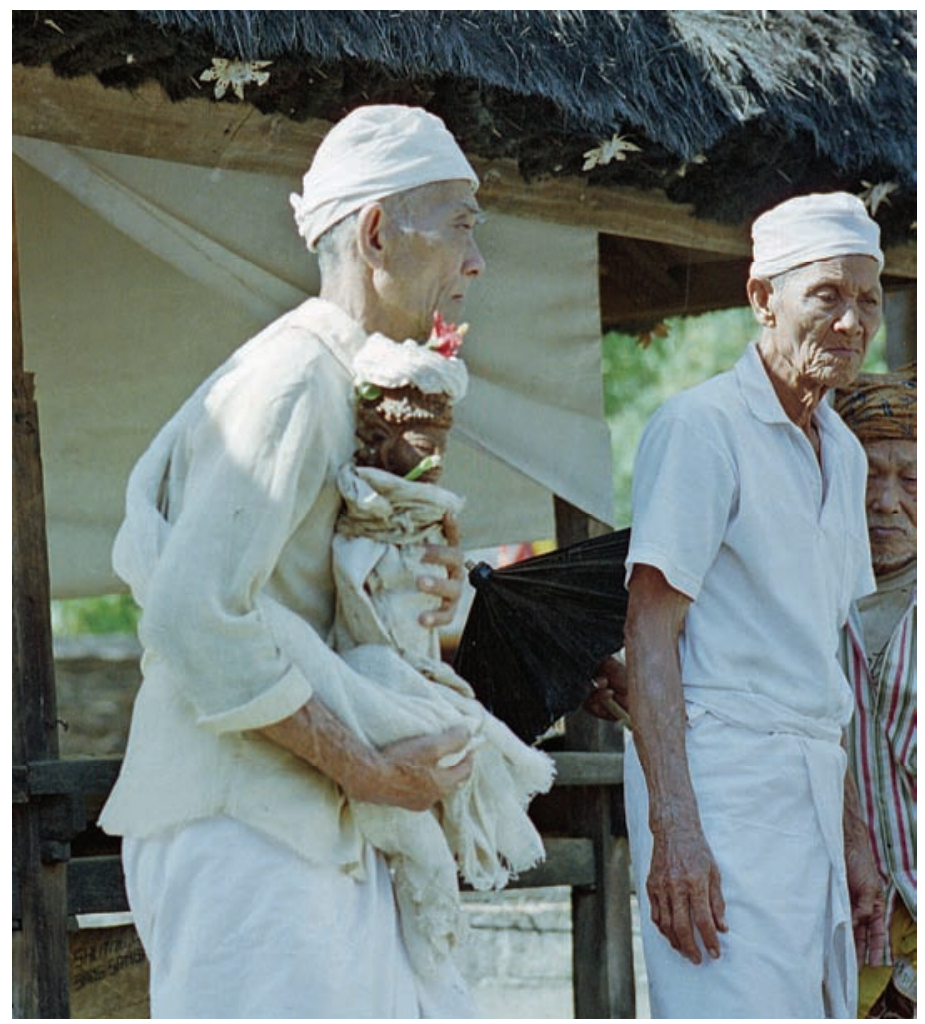

Photo 2: Statues of a royal couple are among the most sacred heirlooms; they are anointed with holy water and fragrance at major temple ceremonies in Julah. Photo: Brigitta Hauser-Schäublin 2001. 
IVa. 1. Punah di çaka 897 bulan cetra krsna pañcami

Lagi Prep saka 897 bulan NmB bulan gelap hari ke 5

Lagi pada tahun saka 897, pada bulan Cetra (Pebruari-Maret) pada hari ke lima

setelah bulan purnama

2. rggas pasar bwijayamanggala, tatkeälan sang ratu

pada pasaran NmT ketika Hon raja

pada hari pasaran di Bwijayamanggala. Tatkala raja

çr i janusādhu warmmadewa, sambhanda dang kryān

$\mathrm{Nm}$ alasan Hon Jbt

Sri Janasadu Warmadewa (menganugrahkan/prasasti). Alasanya adalah Dang Kryan

ser pasar ida kumpi dara dyah damai,

Jbt Hon Jbt Nm

Ser Pasar Ida Kumpi Dara Dyah Damai

mupulang twanak banwa

kumpul Dm penduduk desa

mengumpulkan penduduk desa

3. di julah makapasukuta, balyun to linipetang

Prep NmT sekitar benteng banyak Dm kembali

di Julah dan mereka yang tinggal di sekitar benteng. Oleh karena banyak di

antara mereka yang kembali

dug sang ratu sang lumäh di bwah rangga, saba twa

sejak Hon raja Hon dicandikan Prep NmT oleh sebab itu

sejak pemerintahan Raja yang dicandikan di Bwah Rangga. Itulah sebabnya

syurubda ya kalipetan, maruma di julah, marang santãnan

diberitahu KG3 kembali tinggal Prep NmT semua keturunan

mereka diberitahukan untuk kembali tinggal di Julah bersama semua

keturunannya

4. marumah ditu, yãnugrahanda ya mabharin pandaksayanña, tinggal di sana KG3 dianugrahkan KG3 memelihara prasasti untuk tinggal di sana. Mereka dianugrahi untuk memelihara prasasti

anugrahang sang ratu at itaprabhu, me pirpagebdha dianugrahkan Hon raja sebelum raja dan dikukuhkan

yang dianugrahkan oleh Raja sebelumnya, dan prasasti tersebut agar dikukuhkan 
ya tani kapunaruktan,

KG3 Neg rubah/rusak

dan tidak dirubah/dirusak

5. pangraksayanña, ulih datu kabudi kabudi, me prasasti KG3 oleh Hon yang akan datang dan yang harus dijaga oleh Raja berikutnya dan

caksu paracaksub halyun mangilala drbya haji,

Jbt Jm Jbt semua tukang pungut pajak raja

para Caksu, semua pemungut pajak Raja,

parawuluwulu saprakära, apan ryyuryyam

Jbt dll. karena dibelakang?

parawuluwulu dll. karena dikemudian hari (ketentuan dalam prasasti itu) akan

6. da katurutan dharmmadāyadya, pamasamabyan pandem

Hon berikut pewaris memelihara pemakaman

dituruti oleh pewarisnya. Adapun kewajiban penduduk desa Julah adalah

memelihara pemakaman

bapanda di dharmmakuta, makadanang di balecwara,

Ayah Hon Prep NmT Nm Prep Nm bangunan

yang bernama Baleswara dari ayah Raja di Dharmmakuta

di banwa di bungkulan, saha twa birin sang

Prep desa Prep NmT serta itu Dm beri Hon

di desa di Bungkulan. Yang dianugrahkan oleh Raja

IVb. 1. ratu çr i janãsadhu warmmadewa, twãnak. banwa

Raja Nm Dm penduduk desa

Sri Janasadhu Warmmadewa kepada penduduk desa

di julah mäsu 10 dhikara siwanggada, panundun

Prep NmT mas suwarna $10 \mathrm{Jbt} \quad \mathrm{Nm} \quad$ Jbt

di Julah adalah 10 suwarna mas. Dhikara di Julah adalah Siwanggada, Panundun 
randhi, bulu kayu di widatar trisa, karaksayaña

$\mathrm{Nm}$ Jbt Prep NmT Nm Jbt KG3

adalah Randhi, Hulu Kayu di Widatar adalah Trisa, Karaksayannya adalah

2. banāsuga, gaman, turut juru di kadhuransuwad,

$\mathrm{Nm} \quad \mathrm{Nm}$ berikut Jbt Prep NmT Nm

Banasuga dan Gaman, berikut Juru di Kadhuran adalah Suwad dan

dharmma, bulu kayu di lwaran tranggana, karaksayanña

$\mathrm{Nm}$ Jbt Prep NmT Nm Jbt KG3

Dharmma. Hulu Kayu di Lwaran adalah Tranggana, Karaksayannya adalah

danagana, nubuk, palar, danghwan,

$\mathrm{Nm} \quad \mathrm{Nm} \quad \mathrm{Nm}$ Hon

Danagana, Nuhuk dan Palar.

3. banigräma lamatan kuta, tuha gusali mandhura,

pedagang sekitar? benteng Jbt Nm

Para pedagang di sekitar benteng, Tuha Gusali adalah Mandhura,

astakula sujiwa, danghwan astakaya mahendra,

Jbt Nm Jbt Nm

Astakula adalah Sujiwa, Danghwan Astakaya adalah Mahendra,

kestatade, pratikaya

$\mathrm{Nm} \quad$ Jbt

dan Kestatade. Pratikaya

4. kesawa, karaksayañ̃a ganabhawa, subhama, turut juru

$\mathrm{Nm}$ Jbt $\mathrm{Nm} \quad \mathrm{Nm}$ bersama Jbt

adalah Kesawa, Karaksayan adalah Ganabhawa dan Subhama, bersama empat Juru

di kadhurān makapatang juru, paknayangña to mās

Prep NmT empat Jbt kewajiban Dm emas

di Kadhuran. Kewajiban penduduk desa Julah adalah membayar

paranakangña mā2 kul1 di hatabil

penduduk? KG3 masaka2 kupang 1 Prep pembayaran

2 masaka dan 1 kupang emas yang harus dibayar 
5. hatmwang hatmwang, byayanangña di kärttika setiap tahun pembayaran Prep NmB

setiap tahun, yang pembayaranya setiap bulan Kartika (September-Oktober).

angkĕn rah tirthā teherpakadan nasi balun lamak 10 lyunang setiap waktu air suci juga menyediakan nasi ? lamak 10 jumlah

Setiap Rah Tirtha mereka juga menyediakan 10 lamak nasi balun

nasiña guñja 6 di guñjan panghurwan

nasi KG3 ukuran 6 Prep ukuran Jbt

jumlah nasinya 6 gunja untuk setiap gunja kepada Panghurwan

6. di halamak, beyangña culung, dadih, tangguli,

Prep lamak daging KG3 babi susu tanaman

pada setiap lamak. Mereka harus menyediakan nasi beserta daging babi, susu, tanaman

bartak, siddhu hajengan, pirak daksina upab parjuluk

kacang hijau ukuran minuman perak sajen upah tombak

kacang hijau, minuman arak, uang perak untuk upah penari tombak

mà 1 ku 1 me pamaka

masaka 1 kupang 1 dan menyediakan

1 masaka dan 1 kupang. Mereka juga menyediakan

Va. 1. kadansara blin ku 1 rasuna, balya, blin ku panah pembeli kupang 1 bawang putih jahe pembelian kupang untuk pembelian panah 1 kupang, bawang putih dan jahe 1 kupang harus

crahangña di da kulapati me da karana jataka ditu, beri KG3 Prep Hon Jbt dan Hon Jbt di sana

diberikan kepada Kulapati dan Karana Jataka di Julah

angkèn kärttika me rah tirthä ditu,

setiap $\mathrm{NmN}$ dan? disana

setiap bulan Kartika dan Rah Tirtha di sana

2. hatmwang hatmwang, habhaban tkapyanña 1 lod

setiap tahun memotong kerja Prep laut

setiap tahun. Mereka juga diwajibkan memelihara tempat permandian dekat laut 
pasiwwan, tambak, parigi pager kambang, pangatawanña, permandian tambak teras pagar terapung diketahui KG3

kolam ikan, teras dan pagar terapung. Yang harus diketahuinya adalah

dahan kalod kangin karuh, lantangña

haratus.

arah selatan timur barat panjang KG3 1 ratus

panjang dari pagar terapung itu dari kelod, timur dan barat adalah seratus

3. dwang puluh pitu dpa,

kunang yan ada d urbalan

dua puluh tujuh ukuran jika ada kerusakan

dua puluh tujuh depa. Jika ada kerusakan terhadap

sanghyang paryyangan, me pandem, pañcuran, pasibwan,

bangunan suci dan kuburan tempat permandian tempat permandian

bangunan suci, kuburan, tempat permandian

prasada, jalan raya, denan lodan

tempat pemujaan jalan utama utara selatan

tempat pemujaan dan jalan utama kaja atau kelod.

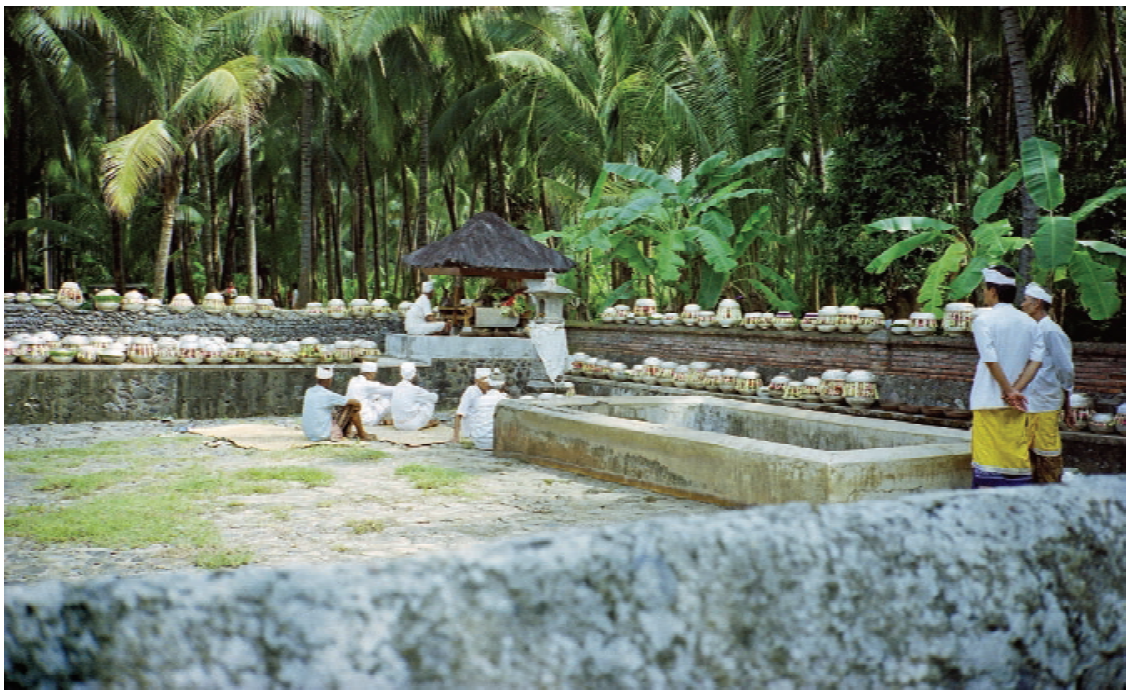

Photo 3: Julah's bathing place near the border of the sea is already mentioned in the inscriptions. The well and the bathing place are annually celebrated (offerings on the wall; ceremonial leaders sitting in an elevated open hall). Photo: Brigitta Hauser-Schäublin 1998. 
4. paburupangña banwa di julah, di indrapura, pertukaran KG3 desa Prep NmT Prep NmT

Biayanya harus ditanggung oleh penduduk desa Julah, Indrapura,

bunundalm, biliran, kabeyanña, amin siwidharmman

NmT NmT pengeluaran? perdikan

Buwundalem, dan Hiliran. Desa-desa tersebut merupakan perdikan dari

sanghyang paryyangan ditu, parbyayanya ya

Hon bangunan suci di sana pengeluaran KG3 KG3

bangunan suci yang ada di sana. Pembiayaanya harus

5. raptangen ya, watu sakasamahangña ulib to wanwa

diperketat KG3 batu dipelihara oleh Dm desa

efisien, batu disediakan oleh penduduk desa

di julab yan ada tarahan tumeken twa partapanan

Prep NmT jika ada perampok datang Dm pertapaan

di Julah. Jika ada perampok yang datang di pertapaan

di dharmmakuta, kapwa ta ya kasamagrin

Prep NmT semua juga KG3 bersama-sama

di Dharmmakuta, semua penduduk harus

6. turun tangga saha sañjata tulungen to patapan

datang dengan senjata membantu Dm pertapaan

datang dengan senjata untuk membantu pertapaan

di dharmmakuta, apan ya prasiddha, ryyuryyang

Prep NmT karena KG3 bisa melindungi akhir

di Dharmmakuta. Oleh karena mereka bisa melindungi pertapaan dan akhirnya

sang ratu dharmmadãyadya ditu, kilagiña di

Hon raja NmT disana ditetapkan Prep

Raja memberikan hadiah ? (kepada penduduk desa Julah). Hal itu ditetapkan

$\mathrm{Vb}$. 1. samohanda senäpati, dipanglapwan makasupratibaddha,

rapat Jbt Prep tempat pesidangan ditetapkan

pada pertemuan Senapati di persidangan. (Keputusan) itu ditetapkan oleh 
senäpati wrsabha ida kumpi tuha masigi,

Jbt NmT Hon Jbt NmT

Senapati Wrasbha adalah Ida Kumpi Tuha Masigi,

da ser krangan tuha manta

Hon Jbt Nm

Ser Krangan adalah Tuha Manta,

2. da nāyakan makar un ida wandàmi bhimatra,

Hon Jbt Hon Nm

Nayakan Makarun adalah Ida Wandami Bhimatra,

da mañuratang äjña tuba wasuwandhu, me

Hon juru tulis Jbt $\mathrm{Nm}$ dan

Juru Tulis Raja adalah Tuha Wasuwandhu, dan

tuha prawāra, da caksu dikērana di wijayapura, tuba

Tuha Prawara, Hon Jbt Prep NmT Nm

Tuha Prawara, Caksu Dikarana di Wijayapura adalah Tuha

3. nogata, da caksu di wijayakrãnta tuba räjana,

$\mathrm{Nm}$ Hon Jbt Prep NmT Nm

Nogata, Caksu di Wijayakranta adalah Tuha Rajana.

da dikarana di panglapuan di wrsabba, tuba dhana,

Hon Nm Prep persidangan Prep NmT Hon Nm

Beliau Dikarana di tempat persidangan di Wrsabha adalah Tuha Dhana,

da di karana di panglapwan (di) pañcakala tuha taran

Hon Jbt Prep persidangan Prep NmT Hon Nm

Beliau Dikarana di tempat persidangan di Pancakala adalah Tuha Taran.

4. da di kearrana di panglapwan di dandawāç̄̄ tubagama,

Hon Jbt Prep persidangan Prep NmT Hon Nm

Beliau Dikarana di tempat persidangan di Dandawaci adalah Tuha Gama.

da di karana di panglapwan di pituba bera, da panglapwan

Hon Jbt Prep persidangan Prep Nm Hon persidangan

Beliau Dikarana di tempat persidangan di Pituha adalah Tuha Bera. Dikarana di tempat persidangan 
di wwit tuba lalita, syuratang da kārana

Prep Nm'T Hon Nm Juru tulis Hon Jbt

di Wwit adalah Tuha Lalita, Juru Tulis Karana

5. wija (ya) pura banaç $\sim \bar{i} / / \mathrm{O} / /$

$\mathrm{NmT} \quad \mathrm{Nm}$

di Wijayapura adalah Banasri. 


\section{No. 351 Sembiran A III}

Vb. 5. Punab di çaka 938 bulan açüi çukla sasti,

Lagi Prep saka 938 bulan $\mathrm{NmB}$ sebelum bulan purnama hari ke enam

Lagi pada tahun saka 938, pada bulan Asuji (September-Oktober), hari keenam sebelum bulan purnama,

rggas pasar bmijawnakerānta, tatkeãlan banwa di julah

ketika pasar NmT ketika desa Prep NmT

ketika hari pasaran Bwijayakranta. Tatkala desa di Julah

makahalamatan kuta me makadbikära, sabaya lamatan kuta

sekitar benteng dan wilayah Jbt sekitar benteng

termasuk benteng dan wilayah adhikara, Sahaya di daerah perbentengan

6. Kayasta tuba santana, pratikāya tuha tambeh,

$\mathrm{Nm} \mathrm{Nm} \quad$ Jbt $\mathrm{Nm}$

adalah Kayasta dan Tuha Santana, Pratikaya adalah Tuha Tambeh,

prakula jangga, astakula balitan, tuha gusali

Jbt Nm Jbt Nm Jbt

Prakula adalah Jangga, Astakula adalah Balitan, Kepala Pandai adalah

VIa. 1. ghalyak, karaksayanña banwa tuba basuta,

$\mathrm{Nm}$ Jbt KG3 Jbt Nm

Ghalyak, Karaksayannya dan Banwa Tuha adalah Basuta dan

dunvel, di widatar bulu kayu rangkap tuba lilit, bupung,

$\mathrm{Nm}$ Prep NmT Jbt menyertai Nm Nm

Duwel, Hulu Kayu di Widatar adalah Tuha Lilit, Bupung dan 
plat, di nuran bulu

Nm Prep Nm'T Jbt

Plat, Hulu Kayu di Nuran

2. kayu tinggar, me subhawan, mañuratang naresa,

Jbt $\mathrm{Nm}$ dan $\mathrm{Nm}$ juru tulis $\mathrm{Nm}$

adalah Tinggar dan Subhawan, Juru Tulis adalah Naresa,

panundun jendra, me astragana, di lwaran bulu kayu,

Jbt $\quad \mathrm{Nm}$ dan Nm Prep NmT Jbt

Panundun adalah Jendra dan Astragana. Hulu Kayu di Lwaran adalah

sukhada, sagun, me bhiksu

$\mathrm{Nm} \quad \mathrm{Nm}$ dan biksu

Sukhada, Sagun, dan Biksu

3. widyambara, makajalan samgat panghumwan uddhawa,

$\mathrm{Nm}$ mediator Jbt Nm

Widyambara, mediator adalah Samgat Panghurwan, Uddhawa

mañambah di sang ratu çri sangajjñadewñ, makahetu,

memuja Prep Hon raja Nm karena

menyembah kepada Sang Ratu Sri Sang Ajnyadewi, karena

makatahwang räm parspara uraña habanwa,

laporan kondisi tersebar satu desa

mereka melaporkan bahwa penduduk desa tersebar di sana-sini

4. mäti, me tyaban musuh, nguniweh lwas majengan

mati dan tangkap musuh terutama pergi tinggal

mati dan ditangkap musuh, ada yang melarikan diri

di banwajohan, kawkeas ta ya kurn 50 ghyäni,

Prep desa jauh sisa Dm KG3 keluarga 50 sekarang

ke desa lain yang letaknya jauh. Sekarang masih ada 50 keluarga, tetapi

müla kurn 300 kunang sangkè $r i$ tani prah

dahulunya keluarga 300 karena kondisi Neg mampu

mulanya/dahulunya 300 keluarga. Karena kondisinya seperti ini mereka tidak mampu 
5. misinin to drbyahajiña sdangñaparipürnna,

mengisi Dm milik raja KG3 secara seluruhnya

membayar pajak seluruhnya dan juga

thēa di balyun buñcang haji saprakeara,

termasuk Prep banyak kerja bakti dll

semua kegiatan kerja bakti, dll.

ya ta mangjadyang sakit kepwan di ya, ya ta haitun

KG3 Dm menjadi sakit menjadi Prep KG3 Dm ingin

Hal ini menyebabkan mereka menderita, oleh sebab itu mereka ingin

6. mañambah di sang ratu mangidbih anugraba titisyānambrta,

menyebabkan Prep Hon raja meminta anugrah hidup

memohon kepada Raja untuk meminta anugrah agar

anandeban sadrabyahäiña, to kyänglubunña kunang pwan

mengurangi semua milik raja Dm ? sebab

dikurangi semua pajaknya. Oleh sebab itu

kāngenangen käsyasih

berpikir kasihan

VIb. 1. to banwa di julah makahalamatan kuta, me di bhäyan bisti jnganña,

Dm desa Prep NmT sekitar benteng dan Prep bahaya bahaya dengan

desa Julah dan daerah perbentengannya dipertimbangkan

yang secara terus menerus dalam bahaya,

hawalan turunan tarahan, tani burung, mäti kahañang, saha twa

terhadap turun perampok Neg jadi mati diserbu oleh sebab Dm

berperang melawan perampok. Mereka tidak urung akan dibunuh atau ditangkap

musuh. Oleh sebab itu

2. kituruna nugrahan sang ratu, to di banwa di julah makahakuta,

turun anugrah Hon raja Dm Prep desa Prep NmT sekitar benteng

turun anugrah Raja kepada desa di Julah dan daerah perbentengannya.

an panngahyan drabyahajiña, ateher pabharinyan pangraksayanña,

setengah milik raja dan juga perbaharui prasasti KG3

Setengah dari pajak harus dibayar dan juga prasastinya harus diperbaharui. 
kunang hwir to

terutama semua jenis Dm

Pajak-pajak yang

3. drabyahajiña yandèh, sambar dwang karundung tkapaña

milik raja KG3 dikurangi pajak dua mata uang tanggung jawab

dikurangi termasuk pajak Sambar 2 karundung. Mereka juga harus menyediakan

me bhojanadi dharmmakuta, lamak 10 pakadān siddhu,

dan makanan Prep NmT mata uang 10 tersedia ukuran

10 lamak makanan di Dharmmakuta, menyediakan

dwangpuluña isiña di hapuluguñja

dua ukuran isi KG3 Prep ukuran ukuran

2 pulu minuman beralkohol. Setiap pulu harus berisi 10 gunja.

4. 10 upahparjuluk mā1 ku 1 pamli dañur ku 2 ärghaña

10 biaya pajak masaka 1 kupang 1 pembelian daun kelapa muda kupang 2 harga KG3

biaya Parjuluk 1 masaka dan 1 kupang. Harga 100 lembar daun kelapa muda adalah

100 lambar, di hakupang, pamli twaken 2 ärghaña bakadung,

100 lembar Prep satu kupang pembelian minuman kupang 2 harga KG3 mata uang

1 kupang. Pembelian minuman biayanya 2 kupang, harga dari setiap kadung

di bakupang, tani

Prep setiap kupang Neg

adalah 1 kupang. Mereka tidak

5. blinyan bhasa, saprakara, me kasumbha, ulih sang ratu,

beli rempah dll. dan kesumba diterima Hon raja

membeli rempah-rempah, dll dan kesumba untuk Raja

me nāyaka, pamahain tring katih 6 pakadaña ptung katih

dan Jbt pembelian bamboo batang 6 sedia bambu batang

dan Nayaka. Mereka harus menyediakan 6 batang bambu, 3 batang bambu ptung

3 tmwan yajñä, gantung dulur pacaraka

3 untuk upacara gantung sambung hamba

untuk upacara. Bambu tersebut harus dihias dan digantung sebagai atribut oleh 
6. häi, di punya turüten tmwan wajantika, tani sisikan, haji Prep donasi bersama? Neg pajak hamba Raja. Mereka harus menyediakan donasi untuk Wajantaka ? Mereka tidak dikenakan pajak Sisikan.

\section{kunang yanada samaña habanwa ditu, mamayar doça} jika ada teman satu desa di sana membayar dosa

Jika ada teman desa Julah membayar untuk kesalahan yang

rayadikitpamayarn ya ludan

besar kecil pembayaran KG3 pajak

besar atau kecil, mereka harus membayar pajak Ludan

VIIa. 1. ndan pangthwangen ya bbhgi bayarña, kunang tetapi pembagian $3 \mathrm{KG} 3$ setiap bagi pembayaran KG3 untuk akan tetapi, pajak Ludan (?) harus dibagi 3, dan hanya $1 / 3$ yang harus dibayar.

bingan to kabakaten ludyan makantang mamayar mā 2

batas Dm jumlah pajak? membayar masaka 2

Batas untuk pajak Ludan adalah 2 masaka.

bahuta, yan mamayar tujuh

? jika membayar tujuh

Apabila mereka membayar tujuh

2. pirak tigangatak, hamas, hakupang satak, tani ludyan, me tani perak $600 \quad 400$ satu kupang $200 \mathrm{Neg}$ pajak dan Neg perak, 600, 400 dan 200 kupang, mereka tidak membayar pajak Ludan? Mereka juga

dampulyan sampi, haturan, besara, kambing, culung,

pajak sapi? bagal kambing babi

tidak dikenakan pajak untuk memelihara bagal, kambing, babi

asu, manuk.

anjing ayam

anjing, ayam

3. kdis, halyun yububña prakara, sahatwa anugrahan sang ratu burung semua dipelihara KG3 dll. juga anugrah Hon raja burung, dan semua yang dipelihara dll. Itulah anugrah Sang Raja 
to di banwa di julah makädhikara yathaña kapangehen kalipeten

Dm Prep desa Prep NmT teritori berhubungan aman kembali

kepada desa di Julah dan wilayahnya. Anugrah itu harus aman dan

paripürnna

sempurna

sempurna sepanjang waktu.

4. kagih kramña usana kilagiña di samohan da senäpati,

bagian penduduk kuna? Prep rapat Hon Jbt

Hak penduduk desa Julah ditetapkan dalam rapat oleh Senapati

ser nāyaka, di panglapwan, makasupratibaddha,

Jbt Prep persidangan ditetapkan

Ser dan Nayaka di Persidangan. Itu ditetapkan

makädi mpungku sewa

terutama pendeta KG1 Nm

terutama oleh Pendeta Sewa

5. sogta, samgat makarun dangacaryya wimalananda, samgat juru wadwä,

$\mathrm{Nm}$ Jbt $\quad \mathrm{Nm} \quad \mathrm{Nm} \quad$ Jbt

Buda. Samgat Makarun adalah Dangacarya Wimalananda, Samgat Juru Wadwa adalah

dangacaryy kesanten, samgat mangirengiren mandami krttartha,

Jbt Nm Jbt Nm

Dangacarya Kesanten, Samgat Mangirengiren adalah Mandami dan Krttartha

6. samgat prah pu taba, samgat tahan taku pu kasih, samgat prataya lali pu homa,

$\mathrm{Nm} \quad \mathrm{Nm}$ Jbt $\quad \mathrm{Nm}$ Jbt $\mathrm{Nm}$

Samgat Prah adalah Pu Taba, Samgat Tahan Taku adalah Pu Kasih, Samgat Prataya

Lali adalah Pu Homa,

samgat mañuratangajña di bulu jamang, samgat mañuratang äjña

Jbt juru tulis raja Prep senior Nm Jbt juru tulis raja

Samgat Juru Tulis yang senior adalah Jamang Samgat, Juru Tulis yang

VIIb. 1. di tngah langkē samgat caksu kärana pura warça

Prep tengah Nm Jbt Nm

di Tengah adalah Lengka, Samgat Caksu Karana Pura adalah Warsa, 
samgat caksu karana kranta mek, samgat pituha gunas

Jbt Nm Jbt Nm

Samgat Caksu Karana Kranta adalah Rnek, Samgat Pituha adalah Gunas.

makadi da senāpati dinganga

terutama Hon Jbt

Terutama Senapati Dinganga

2. pu prajna, me da senäpati tunggalan dyah kayop,

$\mathrm{Nm}$ dan Hon Jbt $\quad \mathrm{Nm}$

adalah Pu Prajna, dan Senapati Tunggalan adalah Dyah Kayop,

da senäpati kuturan pu gawaksa, byarp anak di

Hon Jbt Nm didepan penduduk Prep

Senapati Kuturan adalah Pu Gawaksa di depan penduduk,

karana wijayapura, sawodita.

Jbt NmT Nm

Dikarana di Wijayapura adalah Sawodita. 


\section{No. 409 Sembiran A IV}

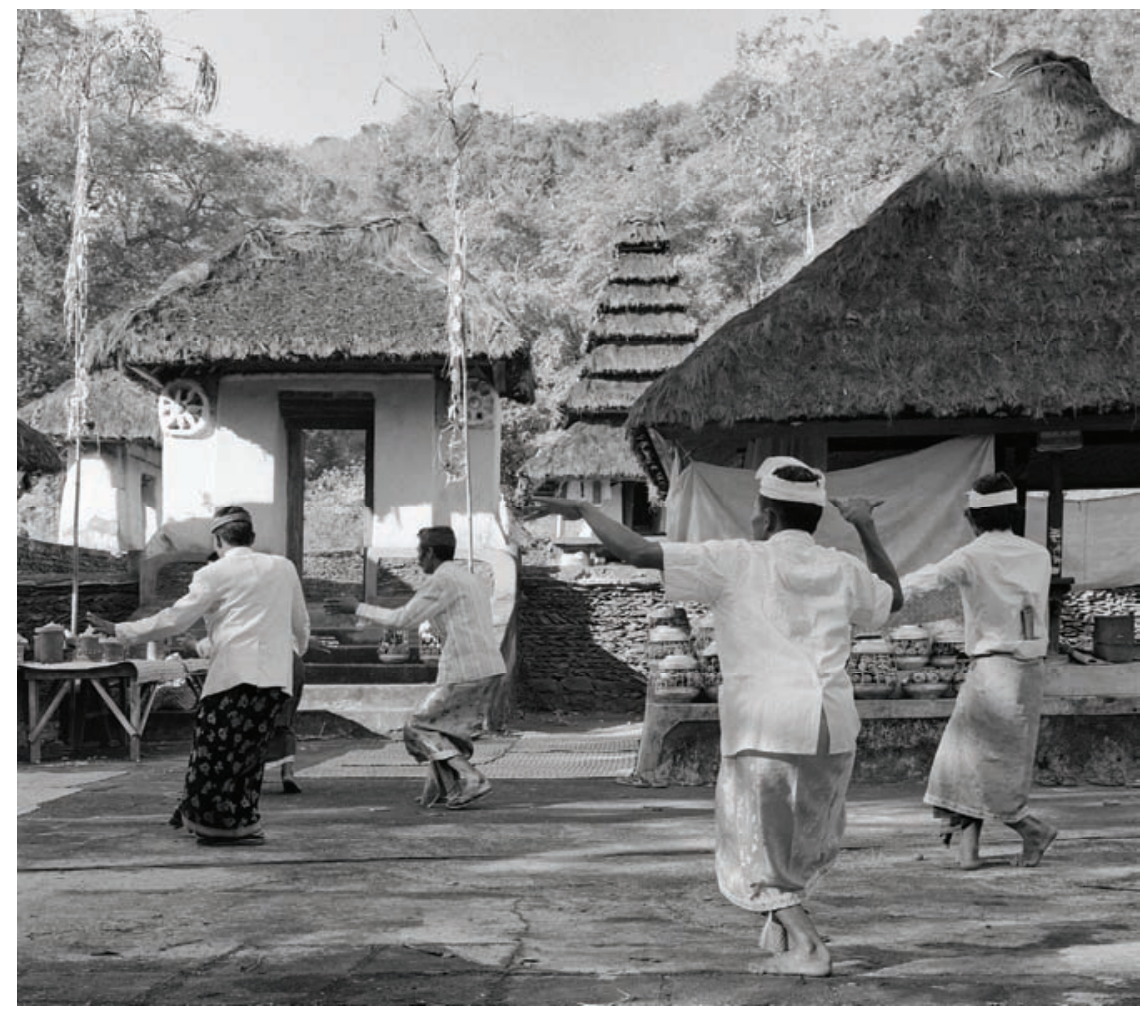

Photo 4: Members of Julah's krama desa perform a dance in the Village Temple to venerate the gods and the deified ancestors.

Photo: Jörg Hauser 2001. 
VIIb. 3. muah i saka 987 bhadrawanta masa tithi sasti suklapaksa

Lagi Prep saka $987 \mathrm{NmB}$ bulan tanggal enam bulan paroh terang Lagi pada tahun saka 987 bulan Bhadrawanta tanggal enam, bulan separoh

terang

pa, $\quad p a, \quad b u, \quad$ wara wariga ning wariga irika diwasa ning karaman paniron, pahing, buda wuku wariga ning wariga Dm saat Prep masyarakat

Paniron, Pahing, Rabu wuku wariga ning Wariga, pada saat itu masyarakat

i julah sadhikara

Prep NmT Jbt

di Julah satu wilayah adhikara.

4. dhikara bapa manija, juru gusali bapa tayamin, banjar bapa sudhiman,

Jbt Nm Jbt Nm Jbt Nm,

Dhikara bernama Bapa Manija, Juru Gusali Bapa Tayamin, Banjar Bapa

Sudhiman,

panulisan bapa sujini, rama kabayan bapa siksaja, banjar $i$ widatar

Jbt Nm, Jbt Nm, Jbt Prep NmT

Juru tulis Bapa Sujini, Rama Kabayan Bapa Siksaja, Banjar di Widatar

5. bapa menetes, panulisan bapa manghwat, rama kabayan bapa agrati

Bapa Menetes, Juru Tulis Bapa Manghwat, Rama Kabayan Bapa Agrati,

i kaduran sahaya bapa paksaja, panulisan bapa bbimaja rama

Prep NmT Jbt Nm, Jbt Nm Jbt

Sahaya di Kaduran bernama Bapa Paksaja, Juru Tulis Bapa Bhimaja, Rama

6. Kabayan bapa sabyaja, lawan pawlah maka tlung juru, i pasuran, parujar

Jbt $\quad \mathrm{Nm}$ dan bagian Prep tiga juru, Prep NmT, Jbt

Kabayan Bapa Sahyaja, dan bagian dari tiga Juru yaitu di Pasuran Parujar

bapa sambibu, i pasilem bapa sukhaman, i pasunggan bapa pu

$\mathrm{Nm} \quad$ Prep NmT Nm, Prep NmT Nm

bernama Bapa Sambibu, di Pasilem Bapa Sukhaman, di Pasunggan Bapa

VIIIa.1. trangsa, samangkana pratyekanya,

papak prasama mapulung rahi

$\mathrm{Nm}$, demikain masing-masing KG3 sama semua berkumpul wajah

Putrangsa. Demikianlah mereka semua bermufakat 
anambah i lbu ni paduka haji anak wungsu nira kalab bhatari

menyembah Prep debu Prep Hon raja Nm KG3 Num bhatari

menyembah ke hadapan Paduka Raja Anak Bungsu beliau berdua yang

lumah $i$ burwan muang

wafat Prep NmT dan

wafat di Burwan dan

2. bhatara dewata lumah ring banu wka, sambandhani panambah nikanang

bhatara dewata wafat Prep NmT, sebab sembah Dm

Bhatara Dewata yang wafat di Banu Wka. Adapun sebab-sebab pejabat

karaman i julah sadhikara $i \quad$ lbu ni paduka haji, anghyang aminta

masyarakat Prep NmT Jbt Prep debu Prep Hon raja, indah minta

desa Julah sewilayah adhikara menghadap Paduka Raja dengan hormat

mereka memohon

nugraha titisanammr

anugrah tetesan air kehidupan

anugrah tetesan air kehidupan

3. tahyun tumambrakna pangraksayanya, anugraniratita prabbu makanimita

ingin menembagakan jaga KG3, anugrah beliau dahulu raja oleh karena

inging menembagakan (prasasti) yang dijaganya, anugrah Raja terdahulu. Oleh

karena

tan subaddha paripurnna kahidepanya tamolabing ripta tha ring

Neg kokoh sempurna pikiran KG3, tetap lontar sampai Prep

dalam pikiran mereka tidak kokoh dan sempurna yang tersurat dalam lontar

dlaba ning dlaba

kemudian Prep akan datang

sampai waktu yang akan datang.

4. teher umratibaddhakna sarasaning pangraksayannya mula itan

kemudian menetapkan segala isi Prep jaga KG3 dahulu, Prep Neg

Kemudian menetapkan segala isi (prasasti) yang dijaganya sejak dahulu tidak

dilaksanakan seperti

mulanya i surubanya sakweh rowangnikanang karamani julah, wineh

dahulu Prep suruh KG3 semua teman Dm masyarakat Prep NmT, diberi

dahulu. Oleh karena itu disuruhlah semua penduduk Julah diberi 
pasek rikana lawan

hadiah Dm serta

hadiah di sana, dan

5. anghyangahyun tumanbrakna satingkah paduka haji ring sambar ikang

hormat ingin menembagakan segala Hon raja Prep upacara Dm

dengan hormat (mereka) ingin menulis dalam tembaga segala ketentuan terhadap

Paduka Raja pada saat upacara Sambar

ikang sipat ma 4 hopanali jaryyajaryyan, acelengamulya ma 4

Dm denda masak 4 pajak setelah itu babi dahulu masaka 4 boleh

yaitu denda 4 masaka termasuk pajak Tali (?) persembahan babi seharga 4

masaka.

wnanga pagawaya

Diizinkan buat

Diizinkan membuat

6. linggis mwang kris, tan sisiken, tan tabitikusen, tan panabura pakupat

linggis dan keris, Neg iuran, Neg iuran, Neg bayar pajak

linggis dan keris, tidak dikenakan sisiken, tahitikusen, tidak membayar Pakupat

tubun tanggapana ring panambaran juga ikanang karaman sakrama

tetapi terima Prep pemujaan juga Dm masyarakat perbuatan

tetapi masyarakat Julah agar menerima kewajiban pada saat upacara Sambar

VIIIb.1. nya ring lagi, karannanyan panambahi lbuni paduka haji

Prep dulu, oleh karena KG3 sembah Prep debu Prep Hon raja seperti kewajiban yang dahulu. Itulah sebabnya mereka menghadap Paduka Raja

makasopana sang senapati balem bunutpu amerta, tan pisan pindwa aminta

perantara Hon Jbt Nm, Neg satu dua meminta

sebagai perantara adalah sang Senapati Balem Bunut Pu Amerta. Tidak sekali dua kali mereka meminta

2. tinekaken sapanghyangnya, matangnyan tumulwi paduka haji

disampaikan permohonan KG3, sebab KG3 kemudian Hon raja

agar disampaikan permohonannya, itulah sebabnya, kemudian Raja 
makon malapkna i tanda rakryan ring pakirakiran i jro makabehan

memerintahkan sidang Prep Jbt Prep Jbt Prep dalam semua

memerintahkan semua pejabat tinggi kerajaan agar mengadakan persidangan

karubun mpungku saiwasogata, umalocita sayatha sambhandha

terutama pendeta Siwa Budha, memikirkan sesuai dengan sebab-sebab

terutama para pendeta Siwa dan Budha untuk memikirkan sesuai dengan

ni panambah nikanang karamani julah sadbikara

Prep sembah Prep masyarakat Prep NmT sewilayah Jbt

alasan dari pada permohonan masyarakat Julah sewilayah adhikara.

iningtinget pwa yan tan sapira pang

Dipertimbangkan PTC jika Neg seberapa

Dipertimbangkanlah bahwa permohonan itu tidak seberapa

3. raksanya ring kabalan tubun humyangaken tumanbrakna

jagaKG3 Prep kekuasaan benar-benar pejelmaan dewa menembagakan

jika dibandingkan dengan kekuasaan Beliau yang benar-benar sebagai penjelmaan

dewa, agar dituliskan pada tembaga

panis paduka haji ring sambar punyaknanya

ketentuan Hon raja Prep upacara agar persembahan KG3

ketentuan mengenai yang dipersembahkan kepada Paduka Raja pada saat upacara

Sambar

ipangraksayanya, thea rikanang panumbas

Prep jaga KG3, sampai Prep pembeli

di dalam prasasti yang dijaganya termasuk pembeli

4. wlit, mulanya anugrah aniratita prabbu, yathanyan tan purih puribana

pajak dahulu KG3 anugrah KG3 dahulu raja, yaitu Neg diubah-ubah

Wlit yang dahulu merupakan anugrah Raja yang telah wafat, agar tidak diubah

tha ring dlaha ning dlaha juga prayojananya, mwang pada tolihen ikanang

sampai waktu yang datang juga tujuanKG3 dan sama hasil Dm

sampai waktu yang akan datang, yang juga merupakan tujuan dan hasil

karaman

masyarakat

(kesepakatan) dari masyarakat 
5. lawan kabalan, an ikang ubhayahitawasana tkapaningagawayanugraha dengan penguasa, Dm persetujuan akhir oleh yang membuat anugrah dengan penguasa. Itulah persetujuan akhir dari yang membuat anugrah.

yathanyan tan pamubara kadurwiwekan $i$ muwahanya paripurnna

Sehingga Neg menimbulkan ketidakwaspadaan Prep berubahKG3 sempurna

Sehingga tidak menimbulkan ketidakwaspadaan terhadap berubahnya

kesempurnaan

IXa. 1. kadi kramanya ringanadi, kalapknanya tumulwi ta ya seperti kebiasaaan KG3 Prep lampau, dipertimbang, kemudian Dm KG3 seperti kebiasaannya pada masa lampau. Setelah dipertimbangkan dengan matang kemudian

binaturaken $i \quad$ lbunipaduka haji an yogyaywanya sapanambahnya diserahkan Prep debu Prep Hon raja yang sepantasKG3 persembahan KG3 diserahkan kepada Paduka Raja tentang kebenaran permohonan mereka (penduduk Julah).

matangnyan dumawuh dharmmanuraga

sebab KG3 turun cinta kasih

Itulah sebabnya turun belas kasihan

2. paduka haji irikanang karamani julah sadhikara inubhayasanmata

Hon raja Prep masyarakat Prep NmT Jbt disetujui

Paduka Raja kepada masyarakat Julah sewilayah adhikara yang disetujui

sabinyangakenya pangakna i pangraksayanya mula,

semua diinginkan KG3 mengenai Prep sarana yang dijaga KG3 dahulu

dengan baik semua yang diinginkan mereka, mengenai sarana hukuman

yang dijaga mereka dahulu.

pratyekanya ikang sipat

Masing-masing KG3 DM ketentuan

Masing-masing dari mereka itu agar memperhatikan ketentuan

3. ing sambar pinuruk ma 5 kahop panalinya tkeng

Prep upacara iuran masaka 5 termasuk iuran KG3 sampai Prep

tentang upacara Sambar berupa Pinuruk 5 masaka termasuk Panalinya

sampai pada 
jaryyajaryya, tan panusuna, acelenga mulya

? Neg digandakan pembelian babi senilai

Jaryyajaryya, tidak digandakan pembelian babi senilai

ma 4 wnangapagawaya linggis mwang kris

masaka 4 dibolehkan membuat linggis Konj keris

4 masaka. Mereka dibolehkan membuat linggis dan keris,

4. tan sipaten tan panabura pakupat, tubun tangkapana

Neg ditentukan Neg membayar pajak tetapi kewajiban

tidak diatur dan tidak membayar Pakupat, tetapi mempunyai kewajiban

i panambaranya juga ya, sakweh tinabilakna

Prep tempat pemujaan KG3 Konj KG3 segala jenis agar dibayarkan

pada tempat pemujaan mereka juga, segala jenis pajak agar dibayarkan

ring caksu sambar apan mangkana pu

Prep Jbt karena demikian aturan

kepada Caksu Sambar karena memang demikian aturan

5. ribnya, panumbas hatep sake sang senapati

KG3 pembelian atap mulai Prep Hon Jbt

nya, pembelian atap mulai dari sang Senapati

tunggalan, samgat kalasanten, mpungkwing byang slat

Jbt pendeta KG1 Prep NmT

Tunggalan, Samgat Kalasanten, pendetaku di Hyang Slat

satak hingananya angken tabun ang

batas KG3 setiap tahun dua

satak batasnya setiap tahun dua

6. Liba, sargha mahajana, tan palakwana paksaya

kali nilai tertinggi Neg dikenakan pajak

kali dari harga yang tertinggi, tidak dikenakan Paksaya

tan pacaksuba, tan sipaten tan tahitikasen

Neg pajak Neg denda Neg iuran?

tidak dikenakan Pacaksuha, tidak dikenakan denda, tidak dikenakan Tahitikasen. 
mangkana yang hana banyaga

demikian jika ada saudagar

Demikian bila ada saudagar

IXb. 1. sakeng sabrang jong bahitra cumunduk i manasa

dari seberang sampang perahu menuju Prep NmT

dari negeri asing memakai sampan, perahu berlabuh di Manasa

awnka kunang hatpi kitekananya, wnanga ikanang

rusak Dm menepi mengalami KG3 boleh Dm

mengalami kerusakan kemudian merapat, penduduk desa itu

karaman patrakasihan wlyana hatep mulya

penduduk desa memohon membeli atap seharga

dibolehkan mengajukan permohonan untuk membeli atap seharga

2. ma 1 anglpiha sargha mahajana, tan papacaksuba

masaka 1 dua kali harga tertinggi Neg pajak

1 masaka sampai dua kali harga tertinggi, tidak dikenakan pajak Pacaksu

tan kna paksaya, ika ta yan pamawa sang

Neg kena pajak Dm PTL jika membawa Hon

tidak dikenakan Paksaya. Itulah bila membawa isi perintah

byang ajnya haji, tinumbuk telek paduka

perintah raja dipukul titik terdalam Hon

Raja (prasasti) dipukul pada titik terdalam oleh Paduka

3. haji ikang pananggapa, tan pakanggeha pangraksayanya

raja Dm orang tamak Neg kedudukan penjagaan KG3

Raja bagi orang yang tamak, tidak mendapat kedudukan dalam

lingkungannya

knaning bulunatata, talitali babiniblab piling, regep

kena budak teratur pajak istri setengah ukuran suami

dikenai giliran penghambaan, dikenai Tali-tali, istri setengah piling, suami

sa 3 saputtayu angken

saga 3 setiap orang setiap

3 saga masing-masing setiap 
4. tahun, mangkana yan hana bhadagina salwirranya

tahun demikian jika ada pemain musik sejenis KG3

tahun. Demikian juga bila ada pemain musik dan sejenisnya

maranmak irikanang karaman $i$ julah sadhikara, yan

datang (menghibur) Prep penduduk Prep NmT sewilayah jika

datang menghibur penduduk desa Julah sewilayah adhikara, apabila

pagendingi baji ma 1 paweha iriya

penyanyi Prep raja masaka 1 bayaran Prep KH3

penyanyi istana 1 masaka bayaran untuknya

5. agending ambaran ku 2 paweha iriya, amukul ku 1

penyanyi keliling kupang 2 bayaran Prep KG3 penabuh kupang 1

penyanyi keliling 2 kupang bayarannya, penabuh gamelan 1 kupang

paweba iriya anuling $i$ baji maranmak $k u \quad 1$ paweba

bayaran Prep KG3 peniup seruling Prep raja menghibur kupang 1 bayaran

bayarannya peniup seruling istana datang menghibur 1 kupang bayaran

iriya, anuling ambaran

Prep KG2 peniup seruling keliling

nya, peniup seruling keliling

6. sa 3 paweha iriya, yan atapukan, pirus, menmen

saga 3 bayaran Prep KG3 jika pemain topeng badut pelawak

3 saga bayarannya. Apabila pemain topeng badut, pelawak

i bajimaranmak ku 2 paweha iriya yan atapukan

Prep raja menghibur kupang 2 bayaran Prep KG3 jika pemain topeng

istana datang menghibur 2 kupang bayarannya, bila pemain topeng

pirus menmen ambaran

badut pelawak keliling

badut, pelawak keliling

Xa. 1. maranmak ku 1 paweha iriya lawan yan hana

datang menghibur kupang 1 bayaran Prep KG3 Konj jika ada

datang menghibur 1 kupang bayarannya. Dan kalau ada 
waringin, skar kuning, wungkudu, puntaja, wodhi

beringin sekar kuning, $\mathrm{NmP} \quad \mathrm{NmP} \quad \mathrm{NmP}$

pohon beringin, sekar kuning, wungkudu puntaja, bodhi

kamalagi lumbang, yang hana wengi parabuning tarhan

asam ? bila ada malam perahu Prep rampasan

pohon asam, rimbun?, bila ada perahu rampasan malam hari

2. tan katon yan tha, angebi tirisan

Neg terlihat jika datang tutup pohon kelapa

kunang wnanga

tidak terlihat pada saat datang. Ditutupi pohon kelapa mereka boleh

ya ramugaknaya, mangkana rowangnya sakaraman tan

KG3 merusak KG3 demikian teman KG3 sedesa Neg

merusaknya. Demikian pula teman sedesanya tidak

wehen lumakwa wadwawadwa $i$ samgatjulah

diberi melakukan penghambaan Prep Jbt NmT

diberikan melakukan penghambaan kepada Samgat Julah

3. tan wurung pinaka wulub punawi, lawan surubanya

Neg urung sebagai Jbt Konj disuruh KG3

tidak urung sebagai Wuluh Panawi, dan disuruhnya

pager kambang ing kuta hanyar wnanga surusuru

pagar kembang Prep NmT dibolehkan kaktus

membuat pagar kembang di Kuta Hanyar dibolehkan menggunakan kaktus

pageranya paratan binlyan angken tabun mwang tan

pagar KG3 tercemar diganti setiap tahun Konj Prep

untuk pagarnya yang rusak agar diganti setiap tahun, dan tidak

4. hana wehen baryyabaryy sila, molabulah mangrapa

ada pemberian berbagai macam batu berbuat terlarang

ada pemberian berbagai jenis batu (sila), berbuat terlarang

rapa ri thaninya, tan pangalapa salinarangannya

Prep desa KG3 Prep memetik segala yang dilarang KG3

di desanya, tidak boleh memetik segala yang dilarangnya 
ngkana, kadyangganing sarwwaphala, mulaphala

demikian seperti Prep buah-buahan umbi-umbian

di sana, seperti buah-buahan, umbi-umbian

5. makading wnangwnang tan panjinga ri jromah seperti Prep binatang piaraan Neg masuk Prep dalam rumah

seperti binatang piaraan tidak diperbolehkan masuk ke dalam rumah

tan paneherakna drwyagrha pariskara, mangkana

Neg membawa milik keluarga alat rumah tangga demikian

tidak diperkenankan membawa alat rumah tangga milik keluarga. Demikian

sakwehning ngapangkapangkah angulwanangawetan

semua Prep hilir mudik dari barat dari timur

bagi semua orang yang hilir mudik, dari barat dari timur

sasangkananya kinonamera

kedatangan KG3 diperintahkan

mereka berasal, mereka diperintahkan

6. kunang salwiranya tan pangalapang kuda kbo sapi juga semua KG3 Neg mengambil kuda kerbau sapi juga semuanya agar tidak mengambil kuda, kerbau, sapi

wdus celeng yan tumurun irikanang pasisi i julah

kambing babi jika turun Prep pantai Prep NmT

kambing, babi. Apabila turun di pantai desa Julah

tan gawayakna salwirningamuhara

tra

Neg mengerjakan segala jenis Prep menyebabkan Neg

agar tidak melakukan segala sesuatu yang menimbulkan kekhawatiran

Xb. 1. sa irikanang karaman, yapwan khana mangkana

Prep penduduk desa jika ada demikian

penduduk desa. Jika ada yang demikian

kengetakna kawwanganya kawatekanya sangkanya

diingatkan keturunan KG3 kelompok KG3 asal KG3

agar diingatkan keturunanya kelompoknya, tempat asalnya 
pajarakna $i \quad$ lbu ni paduka haji tan wurung tibanya

beritahukan Prep masuk Prep Hon raja Neg jadi dijatuhi

agar diberitahukan kepada Paduka Raja, tidak jadi dijatuhi

danda sakera

denda sesuai dengan aturan

denda sesuai dengan aturan

2. maningajnyalangghana, lawan $i$ wnanganyabengbenga

Prep pelanggaran perintah Konj Prep dibolehkan KG3 ruang tertutup

pelanggaran perintah, dan mereka dibolehkan membuat ruangan tertutup

i tasiknya kadi karamani rowangnya pasisi

Prep lautan KG3 seperti dilakukan Prep teman KG3 pantai

di lautan seperti dilakukan oleh temanya di pantai

yathanya paripurnna $r i$ thaninya tan hawuhawan

agar sempurna Prep desa KG3 Prep rusak

agar sempurna keadaan desanya tidak mengalami kerusakan.

kunangyan

apabila

Apabila

3. katkanapadata kaparekpekana musub tan pangantya

kedatangan penjahat dikepung musuh Neg menunggu

kedatangan penjahat? dikepung oleh musuh agar tidak menunggu

tangen milwanututana kadi rowangnya pasisi kabeh

dipanggil ikut serta mengikuti seperti teman KG3 pantai semua

dipanggil ikut serta mengikuti teman-temanya di pantai semua

angingkepa ri sangjata sahawlah yan panututana

melengkapi Prep senjata serta bambo bila mengikuti

agar melengkapi diri dengan senjata, serta bambu bila mengikuti.

4. hawan parabu, tan kalaksepabiryyahiryyana,

lawan

Jalan perahu Neg membuang waktu saling memperhatikan dengan

Dengan perahu tidak membuang-buang waktu, saling memperhatikan sesama 
rowangnya sakaraman, kunang yan hanapnu $i$ wakagong

teman KG3 sedesa apabila ada kura-kura Prep ikan besar

teman sedesa. Apabila ada kura-kura, ikan besar,

layaran manjingi bengbengnya

ikan layaran memasuki ruangan tertutup KG3

ikan layaran memasuki empangnya

5. sapuribnya mula ulahaknanya, kunag pwa yathanya

kebiasaan KG3 dulu laksanakan KG3 Dm PTL

laksanakalah seperti kebiasaannya dahulu. Itulah agar

tan kolabolaha, blam thea ringdlaha ning dlaha

Neg diubah kemudian sampai Prep kemudian Prep kemudian

tidak diubah-ubah pada waktu yang akan datang sampai dikemudian hari

thap nira sangagataprabbu, mwang nayaka theng caksu

oleh KG3 Hon akan datang raja Konj Jbt sampai Prep Jbt

oleh Beliau Raja yang akan datang, dan Nayaka sampai pada Caksu

6. paracaksu salwiranya sarasa sang byang ajnya haji prasasti

Jbt segala macam KG3 isi Hon keputusan raja prasasti

Paracaksu segala isi dari prasasti

anugraha paduka haji ikanang karamani julah sadbikara

anugrah Hon raja Prep penduduk desa NmT sewilayah

anugrah Paduka Raja kepada penduduk desa Julah sewilayahnya

tkeng pawlab makatlung juru matangnya

sampai Prep buwahan ke NUM Jbt agar

sampai pada ketiga Juru bawahanya. Agar

XIa. 1. sinapalaken pananadahaken sapatya $i$ bhatarapunta

berhasil baik dimohonkan kutukan Prep Bhatara Nm

berhasil dengan baik dimohonkan kutukan kepada Bhatara Punta

byang makapamursita simsim mas singhala bentuk

segala penghormatan cincin emas NmT bentuk

Hyang sebagai penghormatan dipersembahkan sebuah cincin 
tunggal bharanya ma 4 tanda baji pana

NUM berat KG3 masaka 4 tanda raja sebagai

emas Singhala beratnya 4 masaka merupakan tanda Raja sebagai

2. kapanadah sapatha rasanikang sapatha, indah pemohon kutukan isi Dm kutukan perhatikan

pemohon kutukan. Isi kutukan itu: Perhatikan

ta kita kamung hyang bhatara puntahyang byang

PTL KG2 KG2 dewa Bhatara Nm dewa

lah oleh kamu sekalian dewa, Bhatara Punta Hyang, Dewa

agasti, maharsi, purmwadaksina, pascimottara, madhya

$\mathrm{Nm} \mathrm{Nm}$ timur selatan barat-utara tengah

Agasti, Maharsi, timur - selatan, barat - utara, tengah

3. urddhamadah, rawi sasi, ksiti jala pawana

atas - bawah matahari bulan tanah air angin

atas - bawah, matahari, bulan, bumi, air, angin

butasana, jayamanakasadharmma, ahoratri sandhya

api pencipta upacara kurban penguasa siang malam pagi

api pencipta upacara kurban, penguasa siang-malam, pagi

dwaya, yaksa raksasa, pisaca, pretasura

sore $\mathrm{Nm}$ raksasa pisaca pretesura

sore, Yaksa, Raksasa, Pisaca, Pretasura

4. garuda gandharwa, graha kinnara, mahoraga

garuda gandharwa graha kinnara mahoraga

Garuda, Gandharwa, Graha, Kinnara, Mahoraga

catwarilokhapala, yama, baruma, kuwera, besawa

empat Prep mata angin Yama Baruma, Kuwera, Besawa

dewa penjaga empat penjuru mata angin: Yama Baruma, Kuwera, Besawa

mwang yaksa, nagaraja, durgadewi

Konj $\mathrm{Nm} \mathrm{Nm} \quad \mathrm{Nm}$

dan Yaksa, Nagaraja, Durgadewi 
5. caturasra, anantasurendra, anatabyang kalamrtyu

penjaga 4 sudut $\mathrm{Nm} \quad \mathrm{Nm}$

dewa penjaga empat sudut: Ananta Surendra, Ananta Hyang Kalamrtyu

gana bhuta, kita milu manarira, umasuking

Nm Nm KG2 ikut menjelma masuk Prep

Gana, Bhuta, kalian ikut menjelma masuk ke dalam

sarbwa masarira, kita

segala berwujud KG2

segala yang berwujud, engkau

6. sakala saksibhuta tumon madoh lawan maparo

nyata saksi buta melihat jauh Konj dekat

sebagai saksi buta yang nyata dapat melihat jauh dan dekat

ring rabineng wngi at rngyoken ikeng samaya

Prep siang Prep malam PTL agar didengar Dm janji

pada siang-malam agar didengarlah janji

sapatha sumpah

kutukan sumpah

kutukan, sumpah

XIb. 1. pamangundangmami ri kita, hyang kabeh, yawayy

pemberitahuan KG1 Prep KH2 dewa semua bila ada

pemberitahuanku pada kalian para dewa semua. Bila ada

ikanang wwang duracara tan yatna ryyanugraba

Dm orang jahat Neg memperhatikan Prep anugrah

orang jahat tidak memperhatikan pada anugrah

paduka haji, irikang karamani julah sadbikara

Hon raja Prep penduduk desa NmT sewilayah

Paduka Raja kepada penduduk desa Julah sewilayahnya,

2. sapasukparimandalanya kabeh, brahmana, ksatriya

dalam batas lingkungan KG3 semua Brahmana Ksatriya

termasuk dalam batas lingkungannya semua, Brahmana, Ksatriya 
wesya, sudra, hadyan, bulun, matuha raryya

Wesya Sudra tuan hamba tua muda

Wesya, Sudra, tuan-hamba, tua-muda.

lakilaki wadwan

laki-laki perempuan

laki-laki, perempuan

3. wiku, grahasta, nayaka, caksu, parasandiwisa

wiku berkeluarga Jbt Jbt para Jbt

wiku, orang yang berkeluarga, Nayaka, Caksu, para Delik Sandhi

asing umulahulah anugraha paduka haji, tka ring dlaha

setiap merubah anugrah Hon raja sampai Prep kemudian

setiap orang yang merubah anugrah Paduka Raja, sampai kepada kemudian

ning dlaha, tasmat kabwataknanya,

patyanta

Prep kemudian semoga mendapat beban berat KG3 bunuh PTL

hari. Semoga mereka mendapat beban berat, bunuhlah

4. ya kamung hyang, deyentatpatitya, tatanoliba ri

KG3 KG2 dewa bila Neg mati KG3 Neg selamat Prep

mereka hai kamu para Dewa. Bila mereka tidak mati, tidak selamat di

wuntat, tattinghala $r i$ hiringan, tarung ring adgan

belakang Neg melihat Prep diikuti terjang Prep badan

kemudian hari, tidak dapat melihat dengan mata, terjanglah di badannya

tampyal $r i \quad k i w a n$, umabi $r i \quad$ tngenan

tendang Prep kiri ulangi Prep kanan

tendang di kiri dan ulangi di kanan,

5. tutuh tundunya, blab kepalanya, sbitaken wtengnya

pukul punggung KG3 pecah kepala KG3 sobek perut KG3

pukul punggungnya, pecahkan kepalanya, sembelihlah perutnya

rantan ususnya, wtwaken dalamnya, dudut hatinya

urai usus KG3 keluarkan jeroan KG3 cabut hati KG3

hamburkan ususnya, keluarkan isi jeroannya, cabut hatinya 
pangan dagingnya, inum

makan daging KG3 minum

makan dagingnya, minum

6. rahnya, whasaken pranantika, yan para ya ring alas darah KG3 akhiri dengan kematian bila pergi KG3 Prep hutan darahnya, akhiri dengan kematian. Apabila pergi ke hutan

panganening mong, patukningula, puliraknaning dimakan Prep harimau pagut Prep ular diputar Prep dimakan harimau, dipagut ular, diputar oleh

dewamanyu, yanparaya ring tgal samber dewa kemarahan jika pergi KG3 Prep ladang disambar Dewa Manyu, kalau pergi mereka ke ladang agar disambar

XIIa. 1. ning glap, sempalning raksasa sarbwa raga rumancaya Prep petir dipeganggal Prep raksasa PBL penyakit mengganggu petir, dipenggal oleh raksasa, segala penyakit menganggunya.

arah ta kita byang kusika, garga metri kurusya

perintah PTL KG2 dewa Nm Nm Nm Nm

Perintahkanlah oleh mu dewa Kusika, Garga, Metri, Kurusya

patanjala, sawnk lor kidul

$\mathrm{Nm}$ tarik utara selatan

Patanjala, tarik ke utara selatan

2. kulwan wetan, bwangaken ringakasa, salambitaken

barat timur lemparkan Prep angkasa agar disiksa

barat, timur lemparkan ke angkasa, agar disiksa

ring sang byang kabaih, tibaken ring mahasamudra

Prep Hon dewa semua jatuhkan Prep samudra luas

oleh dewa semua. Jatuhkan di samudra luas

kelmaken ring sawuban

tenggelamkan Prep danau

tenggelamkan di danau 
3. alapen sang dalmer, dudut ning tawiran diambil Hon $\mathrm{Nm}$ ditarik Prep ikan diambil oleh Sang Dalmer, ditarik oleh ikan tawiran

senghapening wubaya, bhrasta liputening phira

agar disambar Prep buaya hilang dibungkus Prep awan gelap agar disambar buaya, hilang dibungkus awan gelap

muliha ring narakaloka, klan de sangyamabala kembali Prep dunia neraka dimasak Prep Hon Nm pasukan kembali ke dunia neraka dimasak oleh pasukan Dewa Yama

4. palun de sang kingkara, pingpitwa yanpangjanma

dipalu Prep Hon Nm kali NUM bila menjelma

dipalu oleh Sang Kingkara. Tujuh kali bila menjelma menjadi manusia

papa ta ya sangsara, sajiwakala, sakelikning janma

papa PTL KG3 sengsara seumur hidup segala kesalahan Prep manusia

papalah mereka sengsara seumur hidup segala kesusahan manusia

tmahananya awnka tan timwa sama

diderita KG3 hancur Neg menemukan kesejahteraan

dideritanya, hancur tidak menemukan kesejahteraan.

5. mangkana tmahannikang wwang umulaluban sang

demikian akibat Dm orang melanggar Hon

Demikianlah akibat bagi orang yang melanggar

byangujar baji prasasti anugraha paduka haji

perintah raja prasasti anugrah Hon raja

isi prasasti, anugrah Paduka Raja

irikanang karaman $i$ julah sadbikara, the sa

Prep penduduk desa Prep NmT sewilayah sampai

kepada penduduk desa Julah sewilayah adhikara sampai

6. parimandalanya kabeh, mangkana rasanikang sapatha

batas lingkungan KG3 semua demikian isi Dm kutukan

batas lingkungannya semua. Demikian isi kutukan itu 
tinadah sake bhatara puntabyang, tlas sinaksyaken

dimohon Prep Bhatara Nm telah disaksikan

dimohon dari Bhatara Punta Hyang telah disaksikan

ri sammukha tanda rakryan ring

Prep kehadapan Jbt Prep

di hadapan Tanda Rakryan dari segenap

XIIb. 1. pakirakiren i jro makabehan karubun mpungku

pejabat tinggi kerajaan Prep dalam semuanya pertama pendeta Prep KG1

pejabat tinggi kerajaan di dalam semuanya, pertama-tama yang terhormat

pendetaku

saiwasogata, sira hana irikanang kala samangkana

agama Siwa Budha KG3 ada Prep saat yaitu

dari agama Siwa dan Budha, beliau yang hadir pada saat itu, yaitu:

sang senapati balm bunut pu

Hon Jbt Nm

Sang Senapati Balm Bunut bernama Pu

2. ammrta, sang senapati dinganga pu mangurak, sang

$\mathrm{Nm}$ Hon Jbt Nm Hon

Ammrta, Sang Senapati Dinganga bernama Pu Mangurak, Sang

senapati pinatih pu manggala, samgat nayaka saksi

Jbt Nm Jbt

Senapati Pinatih bernama Pu Manggala, Samgat Nayaka Saksi

pu lmbu, samgat manyuratang ajnya

$\mathrm{Nm} \quad \mathrm{Jbt}$

$\mathrm{Pu}$ Lmbu, Samgat Manyuratang Ajnya

3. ri wuntat bamangga, samgat caksukaranapura suker

Prep belakang $\mathrm{Nm} \quad \mathrm{Jbt} \quad \mathrm{Nm}$

di belakang bernama Bamangga, Samgat Caksukaranapura bernama Suker,

samgat adhikaranapura singhaja, samgat caksukaranakranta

Jbt $\quad \mathrm{Nm}$ Jbt

Samgat Adhikaranapura bernama Singhaja, Samgat Caksukaranakranta 
baja, samgat pituba widyaksara, karubun mpungku saiwasogata $\mathrm{Nm}$ Jbt Nm yang terhormat pendeta Prep KG1 Siwa Budha bernama Baja, Samgat Pituha bernama Widyaksara, yang terhormat pendetaku dari Agama Siwa Budha

4. mpungku ring dharmmaryya, wandami widyatma

pendeta Prep KG1 Prep NmT Nm

pendetaku di Dharmmaryya, Wandami bernama Widyatma

samgat mangirenngiren wandami ajiman, sireng Kasaiwan

Jbt Nm KG3 Prep agama Siwa

Samgat Mangirengiren Wandami bernama Ajiman, Beliau dari Agama Siwa

mpungku winor dangacaryya

pendeta Prep KG1 NmT Nm

pendetaku di Winor bernama Dangacaryya

5. Karnnaka, samgat juru wadwa dangacaryya

$\mathrm{Nm} \quad$ Jbt Nm

Karnnaka, Samgat Juru Wadwa Dangacaryya

karnnakananda, tinulisaking lekha ring pakirakiren

bajrangsa

$\mathrm{Nm} \quad$ ditulis Prep penulis Prep lembaga tinggi kerajaan Nm

Karnnakananda, ditulis oleh Penulis di Lembaga Tinggi Kerajaan bernama

Bajrangsa. 


\section{No. 621 Sembiran C}

Ib. 1. i caka 1103 crawanamasa tithi nawami

at saka year 1103 crawana month lunar day 9th

The saka year 1103, the month of Srawana (July-August), the 9th day

cuklapaksa, ma, pa, bu,

before the full moon mawulu, paing, buda(wednesday), before the full moon,

Mawulu (6th day of the 6 day week), Paing (2nd day of the 5 day week), Buda (4th day of the 7 day week),

wara wayang wayang i rika diwaca

week name of week that time

the week of Wayang Wayang. At that time

2. ajna paduka cri mabaraja baji jayapangus arkaja

order (title/honorific) (pn) descendant from sun

the order of Paduka Haji Sri Maharaja Jayapangus (the descendent of the Sun)

cibna saharajapatni dwaya paduka bhatara cri

sign together king's wife two (honorific)

and his two wives, Paduka Bhatari Sri

para

(pn)

Parameswari

3. mecwari indhuja lancana, paduka cri mahadewi

descendant from moon sign, hnr (pn)

(descendant of the moon) and Paduka Sri Mahadewi 
cacangkaja ketana, umajar $i$ parasenapati uming

descendant from moon sign, to speak to ( $\mathrm{ftn}$ ) fall

(descendant of the moon), is given to all Senapati.

4. sor i tanda rakeryan ri pakirakiran i jro makabehan, down to (ftn) at assembly at inside all,

The order of Paduka Haji is brought to the assembly,

karubun mpungku cewasogata, rsi

particularly priest Siva Buddhist, monk

particularly to the priests of Siva and Buddha

5. mahabrahmana, ipingsornyajna paduka crimaharaja,

great brahmin, at fall 3rd pro order hnr king

and the great Brahmins. The reason for the order of Paduka Sri Maharaja

ajaren sira kabeh, sembhandha mangrngo paduka cri

to inform 3rd pro all, reason heard hnr

to them is that he heard about

6. maharaja, rikatidopayan ikang karaman, epu kapgan

king, at having no idea that villagers, worry

the villagers of Julah who were worrying about their problems without

tan wri(ng)daya, alaholahaleb

negator knowing how to find way out lost action tired

being able to solve them. These problems are boring to

sawicara

discuss

discuss.

IIa. 1. pinunipuriban denira sang admaka akmitan deceive by 3rd pro hnr receive keep

They have had additional taxes imposed on them by the
apigajih
i karaman ijulah
kaduran
receiving a reward to villagers of julah
kaduran
tax collectors. The villages of Julah and Kaduran 
pikamitani desa

originally village

originally were

2. kawisesan dening julah sapanjing tani, nun mageyake

rule by julah authority, a part (?)

ruled by Julah itself. This village now has

sarintenya, satungkeb balidwipamandala, ba-

body 3rd pro, whole island of Bali, exist

become a part of the state of Bali.

3. na pwa kanitijnana paduka cri maharaja rumongopeh right behavior hnrking hear essence

Paduka Sri Maharaja knows correct procedures and has heard the

essence of

ning manawa kamandhaka, gunagrahi

of name of book striving after virtue

the book of Manawa Kamandhaka. He is striving after virtue and

kumingking ri

to concern about of

is always concerned about

4. kaswasthan ikang rat, rinaksanira, makadona $\mathrm{ri}$ safety that state, protect 3rd pro, aim of

the welfare of the state which he takes care of, as well as

pagebanika sapthanagara swabhawaning kadi sira

stability seven state nature of as 3rd pro

the stability of the state. It is the nature of

prabhu cakerawr

king supreme

the Supreme

5. tti rajadiraja, sekarajyarajalaskmi makadona ni

king, whole royalty king's wife aim of

Ruler/King with his wives to create the 


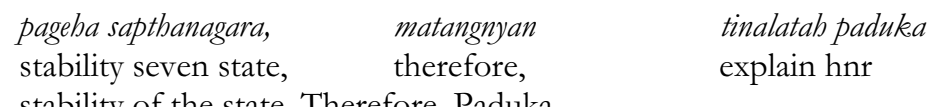

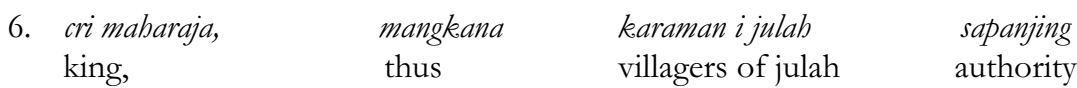

Sri Maharaja gives an explanation. The village of Julah
tani ya ta karananya
makmitana
sanghyang raja
village that reason
keep
hnr king's
will have and guard the king's
prasasti
inscription
inscription.

$\begin{array}{cccc}\text { IIb. 1. agemagem makakemitan } & \text { raksanya } & \text { tugu karaman } \\ \text { hold } & \text { to be guard } & \text { keep } & \text { pillar village }\end{array}$

The inscription has to be guarded and kept as evidence that the village

swatantra rikawakanya pisaningu tanakna pa-

autonomous of be embodied never negator to

is an autonomous territory. It certainly will never

2. rabyapara, karaman i julab

intrude upon another business villager of julah

intrude upon another village's business. The village of Julah

padrwyahajinya tarubkarung ma 4 saputthayu

property king's kinds of tax (cr) way of paying duty

must pay 4 masaka for Taruh Karung (tax on boar fighting ?).

tan

negator

Apart from that they do not pay

3. kna sakwehning padrwyahajyanya parawuluwulu

provide all kinds property king's person of inferior social status

any kind of tax, including the tax of Parawuluwulu (?) 
mwang makapitung bulu tkeng nayakan saksi, makadi and seven social status and (ftn), especially

and all seven taxes of Bulu (?) to the Nayaka saksi, particularly

watu

stone/seed

the tax of Watu

4. npalbur isambar, mwangtan kna

kinds of tax at ceremony, and negator provide

Palbur (?) during the Sambar ceremony. They are not taxed

tangkalik ageng tangkalik alit, mangkana apan

tax of breeding big breeding small, thus because

for breeding, whether big or small animals. This is because they were

tan kna mulanya katmu tinmu ringkarana

negator provide originally meet/find at cause

not taxed originally, from the

5. purwwasthiti ring lagi, tan kna

formerly from the past to present negator provide

past to the present. They are not taxed for

pangleyepalaris tan kna pintapanumbas $r i$

kinds of taxes negator provide tax of purchase at

Pangleye (?) and Palaris (?). They are not Pinta Panumbas (?) when

kalanya patabil drwyahaji ri

time pay property king's at

they pay all kind of taxes (king's property)

6. magha mahanawami rikartikantara purwwabyasa

month of magha big 9th at (month) repetition from the past

on the 9th day of the month of Magha (January-February), and also during the

month of Kartika (October-November). These are the responsibilities of the village

from the past.

kalayaran, tan kna pawwatpacaru mwang byaya,

(?), negator provide kinds of tax and expense

The village does not provide Pawwat (?) and Pacaru (?) and related expenses. 
tan kna

negator provide

It does not provide

IIIa. 1. ni sajisaji saprakara, ring parggapan manawura sa 12

of offering and so forth, at family pay (cr)

offerings and so forth. Families have to pay a tax of 12 saga.

babini mwang kamasan blah ruwa angken maghamaha

woman and gold half two every month of Magha big

It has to be paid on the 9th day of the month of Magha.

2. nawami, mangkana yan hana parawu turun kwehanya yan

9th, thus if exist ship come number if

If canoes,

bana jong banawa salyuning parawu,

exist canoe kinds of ship all number of ship,

junks, boats or any kinds of ship (come to Julah)

samgat badwa haji

(ftn) troop king (title?)

the Samgat Badwa Haji

3. di tengah jugawasesa magaci kabayan, gosti, ida at middle also rule called (?) (ftn) (pn), hnr has authority to (inspect) these watercraft, and the Kabayan Gosti

mangawasa dinara, apan di tngah juga wasa isi

rule (?) because at middle also rule contents

has the right to rule people (?). In the middle (sea), (the Samgat Badwa Haji) has authority to inspect the contents (cargo) of

parawu di

ship at

these ships,

4. patabah, dulangan, pasanggayabusan, i karaman $i$

(?), wooden tray, (?), of villagers of

patabah (?), dulangan (?), pasanggayabusan (?) of the village of 
julah sapanjing tani, badwaji di tngah juga wase julah authority village troop king at middle also rule

Julah and its territory. The Badwa Haji of the middle also has authority

5. sa kunang (?) bebe(ng) lakuning parawu, makasaksi

hold up/block way ship as witness

over broken down ships. As a witness

di tngahjuga mangedum pangtlu

at middle also divide into three

of the middle (of the sea) he divides into three the

6. patatah pasanga habusan dwang bagi katah habagi

(?) (?) (?) two part number a part

Patatah (?), Pasanga (?) and Habusan (?). Two third of these belong to

Samgat Badwa Haji and one

patlu kahoman kabayan gosti, ida mangra

third sacrifice (ftn) (pn), hnr guard

third has to be sacrificed to the Kabayan Gosti. The Kabayan Gosti has authority

IIIb. 1. Kesa desa di nagara, hapan mangingetin abhatiti

village in state, because remember reflecting image of guest

to guard the village in the state. Because he is considered as a guest (?).

mulajuga badwaji di tngah man gingetin arikna

formerly also (ftn) at middle remember tax (?)

The Badwa Haji of the middle also remembers the

mula $i$

original of

original taxes of

2. karaman i julah panjing tani, tan kna

villager of Julah authority village negator provide

the village of Julah, which does not provide the taxes for

pakupat tan kna parmrm, mwang marnit,

(tax) negator provide tax (?) and tax (?)

Pakupat (?), Parmrm (cloudyness?) or Marnit (twinkling?) 
tan pangglar

negator $\operatorname{tax}(?)$

Pangglar (?),

3. turunturun bakatbakat mwang patimtim, tan kna

$\operatorname{tax}(?) \quad \operatorname{tax}(?) \quad$ and tax (?), negator provide

Turunturun (?), Bakatbakat (?) and Patimtim (?). Julah does not provide

papuncagiri, patalitali mwangangempung, tan kna

$\operatorname{tax}(?), \quad$ tax of rope and tax (?), negator provide

Papuncagiri (?), tax or rope, and Pangempung (?). It does not provide

sarwwawija

all kinds of grain

any kind of grain

4. ri mahabanten pawisuwa, prayaccita,

tan

at big offering of (?), purificatory ceremony negator

for the big offering of Pawisuwa (?) and the purification ceremony. Julah does not

kna pajapajapa nguniweb wnangaya

provide tax of mantras(?) particularly allow 3rd pro

provide a tax of muttered prayers or recitation of mantras. The inhabitants are

allowed

nambut gawe sakweh ni candala

take job all kinds of out caste

to take all kinds of jobs out of their castes.

5. Karmma, mwang akekesa sapangalapnya satwa ring alas

act, and keep hide whole catch animal at forest

They are allowed to hide animals and birds which are caught from the forest

theng wunyawunya saprakara, tan pamwita,

include bird (?) and so forth, negator permission

without permission.

tan kna palanting

negator provide tax (?)

They do not provide Palanting (?) 
6. mwang tan kna rot, mangkana yan hana rogan and negator provide tax, thus if exist infirmity and a tax for Rot (?). Thus, it is an infirmity

karaman salah margga byun makastri babini

villagers unusual act want to marry woman

if a villager wants to marry a woman

brabmawangca santana bu-

brahmin descendant of

of Brahmana caste, or a descendant of an outstanding

IVa. 1. jeman juru kling, lawan yan

out standing people (ftn) Indian descendant and if

person such as a Juru Kling (descendant of an Indian?). If

hana putra santana kahulunan salwirani kahulunanya

exist descendant slave all kinds of slave 3rd pro

there are descendants of slaves,

the wadwa, rakrya

include troop, (ftn)

including army/troops, Rakryan (officials),

2. n---- momah $i$ taninya, tan tutudan tunggu

live at villiage 3 rd pro negator reduce wait

who live at the village of Julah, their

bwatt haji, ring pakuwwan tan kna

corvee at place's name negator provide

corvee at Pakuwan is not reduced. They do not provide

buncanghaji ageng

corvee(?) king big

buncang haji (?) big or

3. admit, karan ijulah pinakapagarida di

small, because particle julah as fence hnr at

small. This is because the village of Julah serves as a fence or protector of 
nagara apan di tangaranijuga, pajuritna di julah, state because remind also, troops at julah, the state. The troops at Julah are always alert.

mangkeana inanugraha

thus to be given

This is the grant of

4. nira paduka cri maharaja baji jayapangus yan bana

3rd pro (hnr majesty) (pn) if exist

Paduka Sri Maharaja Haji Jayapangus. If there are

kabyang walyan momah itaninya tan alapen adamla

(hnr) balyan* live at village negator take make

priests at Julah, they are not asked to provide a

wal ipujung

ceremony at place's name

ceremony/contribution at Pujung

5. mwang ipatahan, tan kna rotpabukabuddhi,

and place's name, negator provide tax service (?),

and Patahan. They do not provide Rot Pabukabuddhi (a kind of tax ?),

tan knapasiki, mwang pawija, ateherwnanga

negator provide tax (?), and tax of grain and then allow

Pasiki (?) or Pawija (taxes in grain ?). They are allowed

ya mijilakna sa-

3rd pro make/provide

to provide

6. ra mareng tani salen tan alapen dening

medicine (?) to village other negator take by

medicine to other villages. They are not taxed by

watek ser walyan, mwang bulu kayu ipuja, tan

(ftn) walyan, and (ftn) at ceremony negator

the Ser Walyan and the Hulu Kayu for ceremonies. They do not

${ }^{*}$ Still today, priests are called balyan in Julah (Hauser-Schäublin). 
kna lagani

provide tax

pay tax for

IVb. 1. hnu, tan sipaten lawan yan hana katyagan $r i$ road, negator penalty and if exist monastery roads. They are not penalised. If there is a monastery/hermitage

taninya wnangaya tan pasaja

village 3rd pro allow 3rd pro negator tax or

in their village, they are allowed not to have Pasaja (?) or

ekarapanta $i$ matan parabya-

levy particle negator business of other people

Ekarapanta (?). They do not intrude upon the business of

2. para deni watek kuturan, mangkana yan hana rowang-

by (ftn), thus if exist colleague

Watek Kuturan (officials). Thus, if their colleagues

nya sakaraman anmu anakning wiku rsi, waluning

3rd pro village find people monk priest widow

in Julah find a child of a monk, a priest or a widow of a

wiku $r$

monk

monk or

3. si, tan kna tambangsani kalapitung wnang wiku rsi priest negator provide tax (?) allow monk priest

priest, they do not provide tambangsani Kalapitung (?). Monks and priests are

allowed

momah ri tanin tan senggahenang asu belang,

live at village negator consider as dog with spotted (beggar)

to live at Julah and are not considered as beggars.

karaman iju-

village of julah

The village of Julah 
4. lab tan kna pamli hajiringmanumbul, mwang ring negator provide purchase king of basketry, and of does not provide basketry or shrubs for the king.

gulma, tan wadungana dening undahagi salwirani shrub, negator chop off by craftsman all kinds of The shrubs should not be chopped by craftsmen.

wadungenya, dadyaang

chop allow to

They are allowed to

5. rugaken sakweh ni kayu larangan makadi, kamiri, smash all kinds of tree forbidden such as candlenut cut all kinds of forbidden trees such as candlenut tree,

waringin, boddhi, sekar kuning yan banyan boddhi tree, kinds of tree if banyan, bodhi, and sekar kuning (?), if

sadosa ngeneba bumah

guilty block house

these trees interfere with houses

6. tirisan mwang tan kna katempubha de--coconut tree and negator provide target and coconut trees. They are not taxed by---

ganaganan sabanahana krangan sahanahananing drwya amount of all exist childless all exist property Ganagana (?). All taxes on childlessness and property

Va. 1. nya kapwa munggaha badwaji di tngah, 3rd pro however donate to troop king's in middle should be donated to the Badwa Haji of the middle,

tan hana drwyanya kadi wulu, apan di tngah negator exist property as (?), because in middle including wulu (?), because all 
juga laku druyanyakabeh, ateher

also way property all, and then

their property goes to the middle (state ?). And then,

2. pinarimandhala hingan i taninya, hinganya wetan, to fix whole area boundary of village, boundary east

the boundaries of the village are established. The east boundaries of the village are

tukad mamupur, air lamesung, air tabar, rangreng,

river's name, river's name, river's name, (?),

the river of Mamupur, Air Lamesung, Air Tabar and Rangreng.

hinganya ki-

boundary sea

The seaward boundary is

3. dul, sagara, hinganya kulwan, cading, bakah, renek,

sea, boundary west, place's name, (?), swamp,

the sea. The western boundaries of the village are Cading, Bakah, swamp,

air cacaracas, binganya lor, balibing, air nangka,

river's name, boundary mountain, place's name, river's name

and Air Cacaracas. The mountainward boundaries are Balibing, Air Nangka.

4. po tanduk, beru, air repu, po bacang, air tapiken,

(place's name), (?), river's name, place's name, river's name

Po Tanduk, Beru, Air Repu, Po Bacang, Air Tapiken,

rangre, air runasan, air balatuk, air pubun, bari

(?), river's name, river's name, river's name, banyan tree

Rangre, Air Runusan, Air Balatuk, Air Puhun, banyan tree.

5. ngin, lijong, batu kamodi, tring ror, po taluh,

tree (?), place's name, bamboo ror, place's name

Batu Kamodi, bamboo? and Po Taluh ???

mangkana Imah ni parimandhala cinatur deca,

thus area of border area four cardinal point

These are the boundaries of the four cardinal points of the village of Julah. 
tlas sinaksyaken ri sa-

already witnessed at front

This has been witnessed / confirmed in front of

6. nmuka da rakeryan i jro makabehan, karubun mpungku

of $\mathrm{hnr}(\mathrm{ftn}) \quad$ all, particularly priest

the officials of the assembly, particularly by

sewasogata rsi maha brabmana i pingsor (nya)

Siva Buddhist priest great brahmin of fall down

Sivaite and Buddhist monks, great Brahmana.

Vb. 1. ajna paduka cri maharaja, makadi parasenapati

order majesty king, particularly (ftn)

The grant of Paduka Sri Maharaja has been laid down. The Senapati and

mangkana (m)pungku sewa sogata, sang senapati balm bunut Pu

thus priest of Siva Buddhist, hnr (ftn)

the priests of Siva and Buddha are the Senapati Balm Bunut who is $\mathrm{Pu}$

2. anakas, sang senapati dinganga pu wudasina, sang
(pn), hnr (ftn)
(pn),
hnr

Anakas, the Sang Senapati Dinganga who is Pu Wudasina, the Sang

senapati maniringin $\quad p u$ amuru

(ftn) (pn)

Senapati Maniringin is Pu Amuru

3. lung, sang se(napa)ti kuturan pu nirjanma, samgat
$\mathrm{hnr}(\mathrm{ftn})$
(pn),
hnr

lung, the Sang Senapati Kuturan who is Pu Nirjanma, the

manuratang hajna i bulu (mada) tamwringreh, manurat-

scribe order at front/first (pn), scribe

Senior Scribe who is Madatamwringeh, the Middle Scribe who

ang hajna i tngah matadara

order at middle (pn)

is Matadara, 
4. samgat manuratang hajna i wuntat amaruda, samgat

hnr writer order at last (pn), hnr

the Last Scribe who is Amaruda, the Samgat

caksu karanapura walaharsa, sire(ng) kacewan,

(ftn) (pn), 3rd pro of Saiwa,

Caksu Karanapura who is Walaharsa, the priests of Siva,

mpungkwi (ng) byang (pa)dang

priest place's name

the priest at Hyang Padang who is

5. dangacaryya agrecwara, mpungkwing pasaban dang

hrn (pn), priest place's name hnr

Dangacaryya Agreswara, the priest at Pasaban who is Dang

acaryya amaradwaja, mpungkwing binor dangacaryya

hnr (pn), priest at place's name hnr

Acaryya Amaradwaja, the priest at Binor who is Dangacaryya

blabla,

(pn),

Hlaha.

6. mpungkwi(ng) makarun dangacaryya hadiwangca sireng

priest at (ftn) hnr (pn) 3rd pro

The priest of Makarun is Dangarcaryya Hadiwangsa.

kasogatan mpungkwing kutribanar dang upadyaya

of Buddhist priest at place's name hnr (ftn)

The monk at Kutihanar is Dang Upadyaya

sarbwartharaja.

(pn)

Sarbwatharaja. 
Contributors 



\section{Contributors}

Ardika, I Wayan (*1952), born in Tabanan, Bali. Professor of Archaeology at Udayana University, Denpasar, Bali. BA 1979 at Udayana University, Denpasar, Bali; MA 1987 and Ph.D. in Archaeology 1992 at the Australian National University, Canberra.

Bawono, Rochtri Agung (*1974), born in Ambarawa, Java. Landscape Archaeologist; lecturer at Udayana University, Denpasar, Bali. BA in Archaeology in 1998, Udayana University, Denpasar. MA in Ecology in 2003, Gadjah Mada University, Yogyakarta.

Drawatik, Marini (*1981), born in Bondowoso, Java. Archaeologist. BA in Archaeology in 2004 at Udayana University, Denpasar, Bali.

Hauser-Schäublin, Brigitta, Professor of Anthropology at Göttingen University, Germany. Ph.D. 1975 and Habilitation at Basel University. Visiting professor at Columbia University, New York (1993), New School for Social Research in New York (1994), Dartmouth College, Hanover, New Hampshire (1996) and at L' École des Hautes Études en Sciences Sociales in Paris (2006). Fieldwork in Papua-Neuguinea (1972-1985) and Indonesia (mainly Bali, since 1988). Research Interest: Anthropology of space and the political organization of space; gender; Anthropology of the body.

Kalb, Enrico (*1977), Diploma Geographer, was educated as a certified Geology Technician before he began his studies at the Geographic Institute at Göttingen University. He graduated in 2005 with a diploma thesis on "Erosion modelling and land use interpretation of the coastal region of North-eastern Bali, Indonesia". This study was based on field work in Bali. The thesis was published in 2006: "Erosionsmodellierung und Land- 
nutzungsinterpretation der Küstenregion von Nordost Bali, Indonesien”. Stuttgart: ibidem.

Nabholz-Kartaschoff, Marie-Louise, former head of the Department of Asian Textiles at the Museum of Cultures, Basel, Switzerland. Fieldwork in India (1975), Indonesia (1982, 1988-1990, 1994). She is currently researching different topics of Asian textiles.

Patera, I Wayan (*1950), born in Bedulu, Bali. Archaeologist and Anthropologist, lecturer at Udayana University, Denpasar, Bali. BA in Archaeology in 1981) at Udayana University, Denpasar; M.A. in Anthropology in 1994 at the University of Indonesia, Jakarta.

Schultz, Michael is a Physician and a biological Anthropologist and Professor of Anatomy in the Zentrum Anatomie, University of Göttingen. He holds a Dr.med. (M.D.) and a Dr.phil.nat. (Ph.D.) degree from the University of Frankfurt am Main and a Dr.med.habil. (D.Sc.) degree from the University of Göttingen. His major research interest is in the evolution and the history of diseases and in the influence of environmental factors on prehistoric and early historic populations. He is also working in the functional and comparative anatomy of primates and in Paleoanthropology. He carried out field work in Germany, Austria, Switzerland, Italy, Slovakia, the USA, Mexico, the Union of the Soviet Socialist Republics, Ukraine, Russia, Turkey, Jordan, Iraq, Egypt and has conducted many research projects in Europe, the Near and the Middle East, USA, and Mexico.

Setiawan, I Ketut (*1958), born in Ubud, Bali. Archaeologist; lecturer at Udayana University, Denpasar, Bali. BA in 1984 at Udayana University, Denpasar, Bali. MA in Archaeology in 1995 at the University of Indonesia, Jakarta.

Swastika, I Made (*1951), born in Badung, Bali. Archaeologist; researcher at Balai Arkeologi, Denpasar Bali. BA in 1982 at Udayana University, Denpasar, Bali. MA in 2006 at Hindu Indonesia University, Denpasar, Bali. 


The series „Göttinger Beiträge zur Ethnologie“ is a continuation of the „Göttinger Studien zur Ethnologie“ formerly published by LIT-Verlag.

Göttinger Studien zur Ethnologie hrsg. vom Institut für Ethnologie der Universität Göttingen

Redaktion: Prof. Dr. Ulrich Braukämper und Prof. Dr. Brigitta Hauser-Schäublin

Jutta Borchardt

Von Nomaden zu Gemüsebauern

Auf der Suche nach yörük-Identität bei den Saçıkaralı in der Südwest-Türkei

Bd. 5, 2001, 200 S., 24,90€, br.,

ISBN 3-8258-4470-6

\section{Holger Kirscht}

\section{Ein Dorf in Nordost-Nigeria}

Politische und wirtschaftliche Transformation der bäuerlichen KanuriGesellschaft

Bd. 6, 2001, 360 S., 30,90€, br.,

ISBN 3-8258-4494-3

Michael Dickhardt

Das Räumliche des Kulturellen

Entwurf zu einer kulturanthropologischen Raumtheorie am Beispiel Fiji

Bd. 7, 2001, 328 S., 25,90€, br.,

ISBN 3-8258-5188-5

Dorothea Deterts

Die Gabe im Netz sozialer Beziehungen

Zur sozialen Reproduktion der Kanak in der paicî-Sprachregion um Koné (Neukaledonien)

Bd. 8, 2002, 336 S., 25,90€, br.,

ISBN 3-8258-5656-9

Ulrich Braukämper

Islamic History and Culture in

Southern Ethiopia

Collected Essays

Bd. 9, 2. Aufl. 2004, 208 S., 20,90€, br.,

ISBN 3-8258-5671-2
Brigitta Hauser-Schäublin;

Michael Dickhardt (Hg.)

Kulturelle Räume - räumliche Kultur

Zur Neubestimmung des Verhältnis-

ses zweier fundamentaler Kategorien

menschlicher Praxis

Bd. 10, 2003, 280 S., 25,90€, br.,

ISBN 3-8258-6799-4

Elfriede Hermann; Birgitt Röttger-

Rössler (Hg.)

Lebenswege im Spannungsfeld lokaler und globaler Prozesse

Person, Selbst und Emotion in der ethnologischen Biografieforschung

Bd. 11, 2003, 296 S., 29,90€, br.,

ISBN 3-8258-7049-9

Wolde-Selassie Abbute

Gumuz and Highland Resettlers

Differing strategies of livelihood and

ethnic relations in Metekel, Northwestern

Ethiopia

Bd. 12, 2004, 376 S., 35,90€, br.,

ISBN 3-8258-7819-8

Birgitt Röttger-Rössler

Die kulturelle Modellierung des Ge-

fühls

Ein Beitrag zur Theorie und Methodik ethnologischer Emotionsforschung anhand indonesischer Fallstudien

Bd. 13, 2004, 400 S., $29,90 €$, br.,

ISBN 3-8258-7670-5

Alke Dohrmann

Die Ensete-Gärten der Hadiyya in

Süd-Äthiopien

Kulturelle Bedeutungen einer Nahrungspflanze

Bd. 14, 2005, 376 S., $29,90 €$, br.,

ISBN 3-8258-8125-3

LIT Verlag Berlin - Hamburg - London - Münster - Wien - Zürich

Fresnostr. 248159 Münster

Tel.: 0251 / 6203222 - Fax: 0251 / 9226099

e-Mail: vertrieb@lit-verlag.de - http://www.lit-verlag.de 
Christian Riemenschneider;

Brigitta Hauser-Schäublin (Hg.) „... yang hidup di sini, yang mati di sana"

Upacara lingkaran hidup di Desa Sembiran, Bali (Indonesia)

„Die Lebenden hierhin, die Verstorbenen dorthin..." ist eine Dokumentation von Lebenszyklusriten im Dorf Sembiran, Nordbali (Indonesien). Über zwei Dutzend Rituale gliedern das Leben des Menschen von seinem Werden im Mutterleib bis nach seinem Tode, wenn die Seele schließlich einen Sitz im Ahnentempel erhält - und dort auf ihre Wiedergeburt wartet: Ein neuer Zyklus beginnt. Frauen und Männer gleichermaßen befinden sich in ständiger Transformation, eingebettet in die Beziehungsnetze von Familie, Dorf und jenseitiger Wesen. Das Buch führt in eine Lebenswelt ein, die als in ständiger Veränderung befindlich wahrgenommen wird und die deshalb ritueller Übergänge bedarf. ,....yang hidup di sini, yang mati di sana" adalah suatu dokumentasi upacara-upacara lingkaran hidup di desa Sembiran, Bali Utara (Indonesia). Lebih dari dua lusin upacara menggolongkan kehidupan manusia dari kejadian dalam kandungan ibu sampai sesudah kematian pada saat jiwa pada akhirnya mendapat tempat kediaman di sanggah dadya - dan di sana jiwa itu menantikan kelahirannya kembali: suatu siklus yang baru berawal. Pria dan wanita setara dalam transformasi lanjut, terlingkup dalam jaringan-jaringan hubungan keluarga, desa dan makhluk-makhluk dunia alam baka. Buku ini merupakan introduksi dalam suatu lingkungan hidup yang dipersepsikan sebagai suatu hal yang berada dalam suatu modifikasi yang berkelanjutan dan oleh sebab itu perlu peralihan-peralihan yang bersifat ritual.

Bd. 15, 2006, 120 S., 19,90€, br.,

ISBN 3-8258-9200-X

\section{Hans Reithofer}

\section{The Python Spirit and the Cross}

Becoming Christian in a Highland Community of Papua New Guinea

This study explores the processes of Christianization among the Somaip, a linguistically divided but ritually united group of clans in the western Highlands of Papua New Guinea. Based on ethnographic fieldwork from 1998 to 2000, it focuses on three major issues: (a) conversion motives, (b) the dynamics of 'indigenizing' Christianity, and (c) the negotiation of a new (Christian) identity. The analysis proceeds from an extensive reconstruction of pre-Christian concepts and ritual practices which are also situated in a wider regional context. It is only against this richly painted background of the ancestral religion that one can appreciate the distinctive vigour of current Somaip Christianity as it has been shaped by the creative blending of two religious traditions and the tensions and resonances perceived between them.

Bd. 16, 2006, 408 S., 39,90€, br. ISBN 3-8258-9336-7

\section{Ulrike Claas}

\section{Das Land entlang des Sepik}

Vergangenheitsdarstellungen und Migrationsgeschichte im Gebiet des mittleren Sepik, Papua New Guinea

„Das Land entlang des Sepik“ untersucht mehrere Sammlungen oraler Traditionen aus dem Einzugsgebiet des mittleren Sepik, Papua New Guinea. Die Erzähler und Mythologen des Mittelsepikgebietes fassten ihre Vergangenheit in drei unterschiedliche Ordnungen: eine subclanbezogene Geschichte der Wanderungen, eine siedlungsgruppenbezogene Vergangenheitstheorie der sozialen Ordnung und eine Metageschichte grundsätzlicher kreativer Dichotomien zwischen Leben im Busch und Leben am Fluss, zwischen den Erzfeinden Palimbei und Nyaurangei und zwischen Mutter- und Tochtersiedlungen. Bd. 17, 2007, 464 S., 39,90€, br., ISBN 978-3-8258-9383-5

$$
\begin{gathered}
\text { LIT Verlag Berlin - Hamburg - London - Münster - Wien - Zürich } \\
\text { Fresnostr. } 2 \text { 48159 Münster } \\
\text { Tel.: 0251 / } 6203222 \text { - Fax: 0251 / } 9226099 \\
\text { e-Mail: vertrieb@lit-verlag.de - http://www.lit-verlag.de }
\end{gathered}
$$



$\mathrm{T}$ he villages on Bali's north-east coast have a long history. Archaeological finds have shown that the coastal settlements of Tejakula District enjoyed trading relations with India as long as 2000 years ago or more. Royal decrees dating from the $10^{\text {th }}$ to the $12^{\text {th }}$ century, inscribed on copper tablets and still preserved in the local villages as part of their religious heritage, bear witness to the fact that, over a period of over 1000 years, these played a major role as harbour and trading centres in the transmaritime trade between India and (probably) the Spice Islands. At the same time the inscriptions attest to the complexity in those days of Balinese society, with a hierarchical social organisation headed by a king who resided in the interior - precisely where, nobody knows. The interior was connected to the prosperous coastal settlements through a network of trade and ritual. The questions that faced the German-Balinese research team were first: Was there anything left over of this evidently glorious past? And second: Would our professional anthropological and archaeological research work be able to throw any more light on the vibrant past of these villages? This book is an attempt to answer both these and further questions on Bali's coastal settlements, their history and culture. 